\begin{abstract}
UNIVERSIDADE DE SÃO PAULO
ESCOLA DE ENGENHARIA DE SÃO CARLOS

CENTRO DE RECURSOS HÍDRICOS E ECOLOGIA APLICADA

PÓS-GRADUAÇÃO EM CIÊNCIAS DA ENGENHARIA AMBIENTAL
\end{abstract}

DIEGO MENDONÇA ARANTES

\title{
DEPOSIÇÃO E EXPORTAÇÃO DE SÓLIDOS E NUTRIENTES NA SUB-BACIA DO RIBEIRÃO \\ DAS CRUZES, BAIXO TIETÊ (SP)
}




\title{
DEPOSIÇÃO E EXPORTAÇÃO DE SÓLIDOS E NUTRIENTES NA SUB-BACIA DO RIBEIRÃO DAS CRUZES, BAIXO TIETÊ (SP)
}

\begin{abstract}
Dissertação apresentada à Escola de Engenharia de São Carlos, da Universidade de São Paulo, como parte dos requisitos para obtenção do título de mestre em Ciências da Engenharia Ambiental.
\end{abstract}

Orientador: Prof. Dr. Frederico Fábio Mauad

São Carlos

2012 
AUTORIZO A REPRODUÇÃO E DIVULGAÇÃO TOTAL OU PARCIAL DESTE TRABALHO, POR QUALQUER MEIO CONVENCIONAL OU ELETRÔNICO, PARA FINS DE ESTUDO E PESQUISA, DESDE QUE CITADA A FONTE.

Ficha catalográfica preparada pela Seção de Tratamento da Informação do Serviço de Biblioteca - EESC/USP

\begin{tabular}{|c|c|}
\hline \multirow[t]{3}{*}{$\mathrm{A} 662 \mathrm{~d}$} & $\begin{array}{l}\text { Arantes, Diego Mendonça } \\
\text { Deposição e exportação de sólidos e nutrientes na } \\
\text { sub-bacia do Ribeirão das Cruzes, baixo Tietê (SP); } \\
\text { orientador Frederico Fábio Mauad. São Carlos, 2012. }\end{array}$ \\
\hline & $\begin{array}{l}\text { Dissertação (Mestrado - Programa de Pós-Graduação } \\
\text { em Engenharia Ambiental) -- Escola de Engenharia de São } \\
\text { Carlos da Universidade de São Paulo, } 2012 \text {. }\end{array}$ \\
\hline & $\begin{array}{l}\text { 1. Baixo Tietê (SP). 2. Taxas de sedimentação. } 3 \text {. } \\
\text { Deposição de nutrientes. 4. Eutrofização. } 5 \text {. } \\
\text { Assoreamento. I. Título. }\end{array}$ \\
\hline
\end{tabular}




\section{FOLHA DE JULGAMENTO}

Candidato: Engenheiro DIEGO MENDONÇA ARANTES.

Título da dissertação: "Deposição e exportação de sólidos e nutrientes na sub-bacia do Ribeirão das Cruzes, Baixo Tietê (SP)".

Data da defesa: 14/09/2012

\section{Comissão Julgadora:}

Prof. Dr. Frederico Fabio Mauad (Orientador)

(Escola de Engenharia de São Carlos/EESC)

Prof. Dr. Raoul Henry

(UNESP/Campus de Botucatu)

Prof ${ }^{a}$. Titular Maria do Carmo Calijuri

(Escola de Engenharia de São Carlos/EESC)

\section{Resultado:}
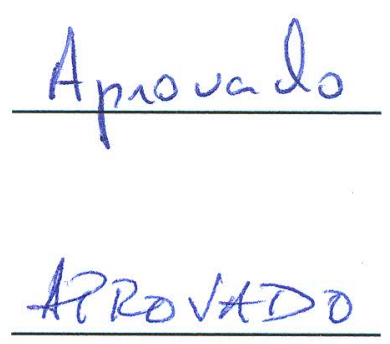

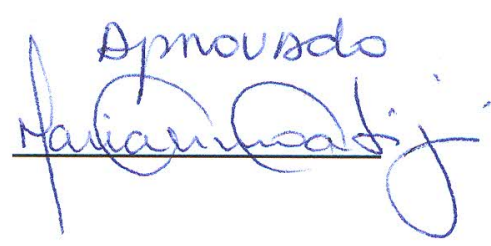

Coordenador do Programa de Pós-Graduação em Ciências da Engenharia Ambiental:

Prof. Dr. Frederico Fabio Mauad

Presidente da Comissão de Pós-Graduação:

Prof. Titular Denis Vinicius Coury 
Dedico este trabalho às pessoas mais importante de minha vida: minha mãe Silvia, meu pai Uedson, meu irmão Eduardo, e minha noiva Larissa.

Amo muito vocês! 


\section{AGRADECIMENTOS}

Primeiramente à Deus, pela vida.

Ao Prof. Dr. Frederico Fábio Mauad, pela orientação, amizade, conselhos e confiança.

À $\operatorname{Dr}^{\mathrm{a}}$. Juliana Moccellin, pela dedicação, orientação, prestatividade, paciência e ajuda no desenvolvimento de todo este trabalho, desde sua concepção, condução dos experimentos em campo, análises laboratoriais e interpretação dos resultados.

Ao Programa de Pós-Graduação em Ciências da Engenharia Ambiental - PPG-SEA e ao Conselho Nacional de Desenvolvimento Científico e Tecnológico - CNPq, pela bolsa de estudos concedida.

À Fundação de Amparo à Pesquisa do Estado de São Paulo - FAPESP que, por meio do Processo 2010/51225-4, financiou este trabalho.

Ao Núcleo de Hidrometria do Centro de Recursos Hídricos e Ecologia Aplicada da Escola de Engenharia de São Carlos - NH/CRHEA/EESC, pelo suporte material, pessoal e técnico que possibilitaram o desenvolvimento deste trabalho.

Ao Técnico Hidrometrista Waldomiro Antonio Filho, pelo companheirismo e toda ajuda durante os trabalhos de campo.

Aos amigos do Núcleo de Hidrometria: Juliana, Gustavo, Renato, Taiana, Roberta, Marcus Vinícius, Julio, André, Paulo, pela amizade, sugestões e longos cafés.

Aos meus pais, Silvia e Uedson, e ao meu irmão Eduardo, pelo amor incondicional, pelo aconchego da família e por entenderem minha ausência. Só consegui chegar até aqui pois sempre contei com o apoio de vocês.

À Larissa, por seu amor, carinho, incentivo e paciência, durante todo este trabalho e os últimos dez anos de minha vida. 


\section{RESUMO}

ARANTES, D. M. Deposição e exportação de sólidos e nutrientes na sub-bacia do Ribeirão das Cruzes, Baixo Tietê (SP). 2012. 123 p. Dissertação (Mestrado) - Escola de Engenharia de São Carlos, Universidade de São Paulo, São Carlos, 2012.

A qualidade ambiental de um corpo d'água é resultado da situação de sua bacia de drenagem, de modo que as transformações que ocorrem no solo do entorno provocam mudanças significativas no ambiente aquático. Por isto, cada vez mais se trabalha com conceito de manejo integrado dos ambientes. Desta forma, o conhecimento dos processos de geração, transporte e deposição de sedimentos, por serem fontes de sólidos, nutrientes e contaminantes ao corpo d'água, é de vital importância para a conservação, desenvolvimento e manejo integrado dos recursos hídricos. Neste sentido, essa dissertação apresenta um estudo a respeito da exportação e deposição de sólidos e nutrientes na sub-bacia do Ribeirão das Cruzes, no município de Santo Antônio do Aracanguá, SP, na Unidade de Gerenciamento de Recursos Hídricos do Baixo Tietê (UGRHI - 19). Esse corpo d'água foi subdividido em compartimentos e analisado por transectos, ou seja, eixos transversais ao fluxo, sendo que experimentos envolvendo instalação de câmaras de sedimentação, coleta de sedimentos de fundo e medições de vazão foram conduzidos em dois períodos hidrológicos distintos: um em janeiro, durante a estação chuvosa, e outro em agosto, durante a estação seca. A taxa máxima de deposição de sólidos suspensos foi de $62,40 \mathrm{~g} \mathrm{~m}^{-2}$ dia $^{-1}$ durante a Estação Chuvosa, e de $37,29 \mathrm{~g} \mathrm{~m}^{-2} \mathrm{dia}^{-1}$, durante a Estação seca. Ainda, a taxa média de deposição de nitrogênio total Kjeldahl foi de 0,53 e 2,02 $\mathrm{g} \mathrm{m}^{-2} \mathrm{dia}^{-1}$ e a de fósforo total foi de 139,67 e 103,89 $\mathrm{mg} \mathrm{m}^{-2} \mathrm{dia}^{-1}$, durante as Estações Chuvosa e Seca, respectivamente. Quanto às taxas de exportação, para sólidos suspensos foram observadas médias de 2328,44 e 725,96 ton dia $^{-1}$, de nitrogênio total Kjeldahl foram de 121,41 e 299,84 ton dia $^{-1}$ e para fósforo total foram de 14,86 e 10,05 ton $\mathrm{dia}^{-1}$, durante as Estações Chuvosa e Seca, respectivamente. Os resultados obtidos, comparados a outros estudos em ambientes similares, revelam altas taxas de deposição e exportação de sólidos e nutrientes, demonstrando, desta forma, a incidência dos processos de eutrofização e assoreamento do recurso hídrico, bem como a expressão dos impactos provenientes do uso e ocupação do solo do entorno, capaz de influenciar na qualidade da água do ambiente.

Palavras-chave: Baixo Tietê (SP), taxas de sedimentação, deposição de nutrientes, eutrofização, assoreamento. 


\begin{abstract}
ARANTES, D. M. Solids and nutrients deposition and exports in Ribeirão das Cruzes sub-basin, Baixo Tietê (SP). 2012. 123 p. Dissertation (Master's degree) - School of Engineering of São Carlos, University of São Paulo, São Carlos, 2012.

The environmental quality of waterbody is the result of the situation of its drainage basin, so that the transformations that occur on the soils surrounding cause significant changes in the aquatic environment. Therefore, each time more has been increasing the works with the concept of integrated management of environments. Thus, the knowledge about the processes of generation, transport and deposition of sediments, because they are sources of solids, nutrients and contaminants to waterbody, is extremely important for the conservation, development and integrated management of water resources. In this way, this dissertation presents a study concerning the deposition and export of solids and nutrients in the Ribeirão das Cruzes sub-basin, in Santo Antônio do Aracanguá city, SP, in Baixo Tietê Water Resources Management Unit (WRMU - 19). This waterbody was divided into compartments and analyzed by transects, which are transverse axes to the flow, and experiments involving installation of sedimentation traps, collect of bottom sediments and flow measurements were carried out in two distinct hydrological periods: one in January during the rainy season, and another in August, during the dry season. The maximum suspended solids deposition rate were $62.40 \mathrm{~g} \mathrm{~m}^{-2}$ day $^{-1}$ during the rainy season, and $37.29 \mathrm{~g} \mathrm{~m}^{-2}$ day $^{-1}$ during the dry season. So, the average rate of nitrogen deposition were 0.53 and $2.02 \mathrm{~g} \mathrm{~m}^{-2} \mathrm{day}^{-1}$, and the rate of phosphorus were 139.67 and $103.89 \mathrm{mg} \mathrm{m}^{-2}$ day $^{-1}$, during the rainy and dry seasons, respectively. As for exportation rates, the average rates found of suspended solids were 725.96 and 2328.44 ton day $^{-1}$, the rates of nitrogen were 121.41 and 299.84 ton day $^{-1}$, the rates of phosphorus were 14.86 and 10.05 ton day ${ }^{-1}$, during the rainy and dry seasons, respectively. The results obtained, when compared to other studies in similar environments, show high rates of solids and nutrients deposition and export, demonstrating, this way, the incidence of eutrophication processes and siltation of the water resources, as well as the expression of impacts from the landuse, able to influence the water quality.
\end{abstract}

Keywords: Baixo Tietê (SP), sedimentation rates, nutrient deposition, eutrophication, siltation. 


\section{LISTA DE FIGURAS}

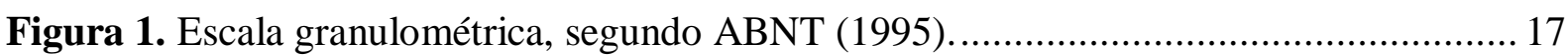

Figura 2. Exemplo de erosão em sulcos........................................................................ 24

Figura 3. Exemplo de erosão em ravinas. .................................................................... 24

Figura 4. Exemplo de erosão em voçorocas, na sub-bacia do Ribeirão das Cruzes, Baixo

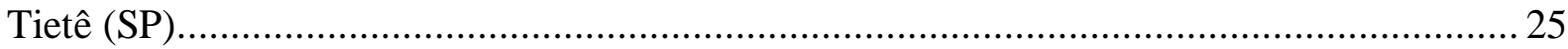

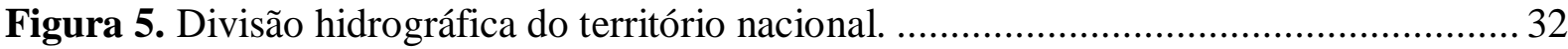

Figura 6. Divisão hidrográfica do Estado de São Paulo. Em destaque a Unidade de Gerenciamento de Recursos Hídricos n. ${ }^{\circ} 19$ - Bacia Hidrográfica do Baixo Tietê................ 34

Figura 7. Localização da sub-bacia do Ribeirão das Cruzes................................................ 39

Figura 8. Carta de uso e ocupação do solo da sub-bacia do Ribeirão das Cruzes e localização

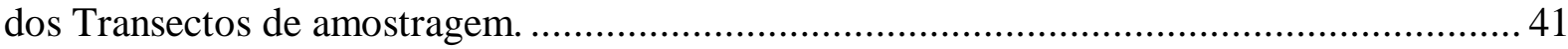

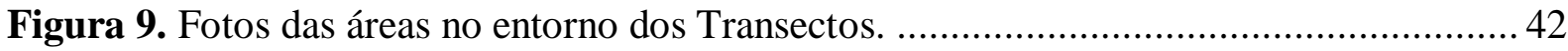

Figura 10. Dispersão entre os pontos de coleta nos Transectos. ...................................... 44

Figura 10. Sonda multiparâmetros modelo YSI 6820, utilizada nos trabalhos de campo...... 47

Figura 11. Armadilhas de sedimentação, utilizadas nos trabalhos de campo. ....................... 48

Figura 12. Esquema de tratamento e análise das amostras coletadas. ................................. 49

Figura 13. Fluxograma das atividades para cálculo da vazão. .........................................56

Figura 14. Representação do funcionamento de um ADP para medição da vazão de rios..... 57

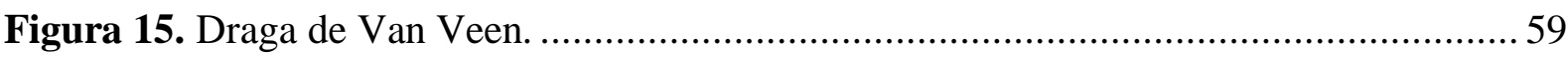

Figura 16. Esquema de funcionamento da draga de Van Veen para coleta de sedimentos. ... 59

Figura 17. Diagrama ternário para classificação dos sedimentos segundo Flemming (2000).63

Figura 19. Perfis verticais da concentração de oxigênio dissolvido, $\mathrm{pH}$ e temperatura do Transecto 1, nas Estações Chuvosa e Seca.

Figura 20. Perfis verticais da concentração de oxigênio dissolvido, $\mathrm{pH}$ e temperatura do Transecto 2, nas Estações Chuvosa e Seca. 66

Figura 21. Perfis verticais da concentração de oxigênio dissolvido, $\mathrm{pH}$ e temperatura do Transecto 3, nas Estações Chuvosa e Seca. 
Figura 22. Perfis verticais da concentração de oxigênio dissolvido, $\mathrm{pH}$ e temperatura do Transecto 4, nas Estações Chuvosa e Seca.

Figura 23. Perfis verticais da concentração de oxigênio dissolvido, $\mathrm{pH}$ e temperatura do Transecto 5, nas Estações Chuvosa e Seca.

Figura 24. Perfis verticais da concentração de oxigênio dissolvido, $\mathrm{pH}$ e temperatura do Transecto 6, nas Estações Chuvosa e Seca.

Figura 25. Perfis verticais da concentração de oxigênio dissolvido, $\mathrm{pH}$ e temperatura do Transecto 7, nas Estações Chuvosa e Seca.

Figura 26. Taxa de deposição de sólidos suspensos - orgânicos e inorgânicos $\left(\mathrm{g} \mathrm{m}^{-2} \operatorname{dia}^{-1}\right) .74$

Figura 27. Taxa de deposição de nitrito $\left(\mathrm{mg} \mathrm{m}^{-2} \mathrm{dia}^{-1}\right)$ 75

Figura 28. Taxa de deposição de nitrato $\left(\mathrm{g} \mathrm{m}^{-2} \mathrm{dia}^{-1}\right)$. 76

Figura 29. Taxa de deposição de nitrogênio amoniacal $\left(\mathrm{g} \mathrm{m}^{-2} \operatorname{dia}^{-1}\right)$. 78

Figura 30. Taxa de deposição de nitrogênio total Kjeldahl $\left(\mathrm{g} \mathrm{m}^{-2} \operatorname{dia}^{-1}\right)$. 78

Figura 31. Taxa de deposição de fosfato total dissolvido $\left(\mathrm{mg} \mathrm{m}^{-2} \mathrm{dia}^{-1}\right)$.... 79

Figura 32. Taxa de deposição de ortofosfato $\left(\mathrm{mg} \mathrm{m}^{-2} \mathrm{dia}^{-1}\right)$ 80

Figura 33. Taxa de deposição de fósforo total $\left(\mathrm{mg} \mathrm{m}^{-2} \operatorname{dia}^{-1}\right)$ 81

Figura 34. Taxa de deposição de silicato reativo $\left(\mathrm{g} \mathrm{m}^{-2} \mathrm{dia}^{-1}\right)$. 82

Figura 35. Gráficos da medição da vazão do Transecto 1, utilizando o ADP. 83

Figura 36. Gráficos da medição da vazão do Transecto 2, utilizando o ADP 84

Figura 37. Gráficos da medição da vazão do Transecto 3, utilizando o ADP. 85

Figura 38. Gráficos da medição da vazão do Transecto 4, utilizando o ADP. 86

Figura 39. Gráficos da medição da vazão do Transecto 5, utilizando o ADP. 87

Figura 40. Gráficos da medição da vazão do Transecto 6, utilizando o ADP. 88

Figura 41. Gráfico da medição da vazão do Transecto 7, utilizando o ADP. 89

Figura 42. Variação das áreas dos transectos e das velocidades médias da água. 90

Figura 44. Taxa de exportação de sólidos suspensos (ton $\left.\operatorname{dia}^{-1}\right)$. 93

Figura 45. Taxa de exportação de nitrito $\left(\mathrm{kg} \mathrm{dia}^{-1}\right)$. 93

Figura 46. Taxa de exportação de nitrato (ton dia ${ }^{-1}$ ). 95

Figura 47. Taxa de exportação de nitrogênio amoniacal (ton dia ${ }^{-1}$ ). 95 
Figura 48. Taxa de exportação de nitrogênio total Kjeldahl (ton $\left.\operatorname{dia}^{-1}\right)$............................. 96

Figura 49. Taxa de exportação de fosfato total dissolvido (ton $\operatorname{dia}^{-1}$ ). ............................. 98

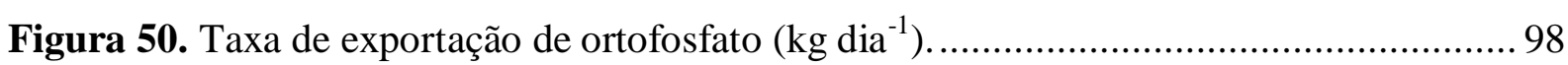

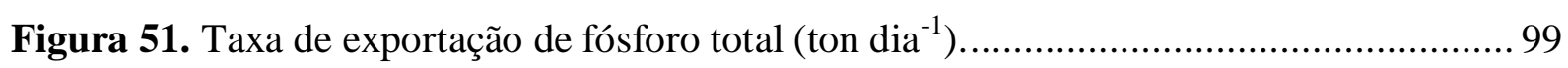

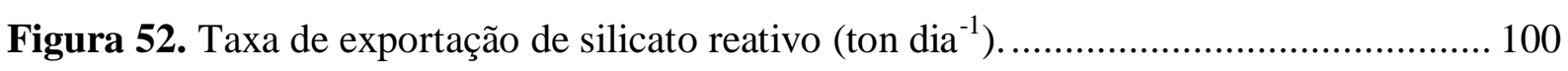

Figura 53. Concentração de nitrogênio total nos sedimentos de fundo $\left(\mathrm{mg} \mathrm{g}^{-1}\right)$................. 103

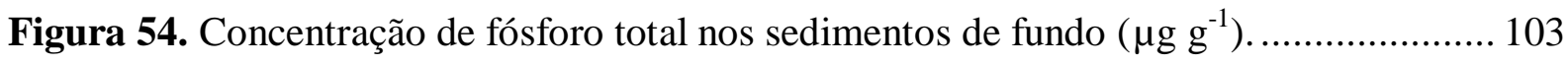

Figura 55. Concentração de matéria orgânica nos sedimentos de fundo (\%). ..................... 104

Figura 56. Granulometria dos sedimentos de fundo do Transecto 1 do Ribeirão das Cruzes

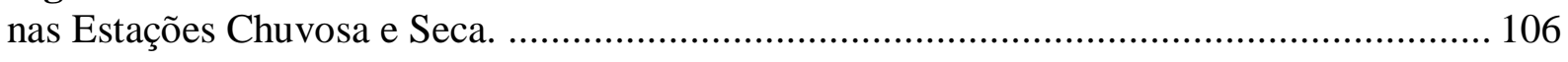

Figura 57. Granulometria dos sedimentos de fundo do Transecto 2 do Ribeirão das Cruzes

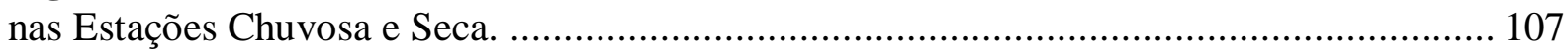

Figura 58. Granulometria dos sedimentos de fundo do Transecto 3 do Ribeirão das Cruzes

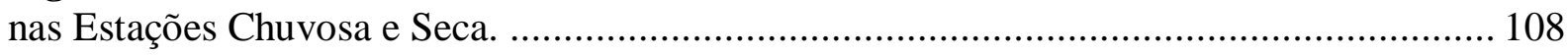

Figura 59. Granulometria dos sedimentos de fundo do Transecto 4 do Ribeirão das Cruzes

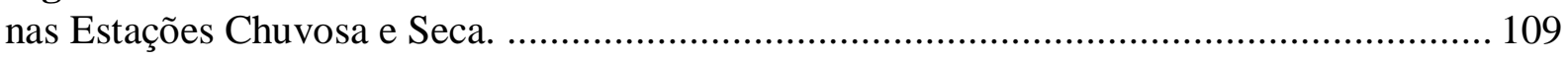

Figura 60. Granulometria dos sedimentos de fundo do Transecto 5 do Ribeirão das Cruzes

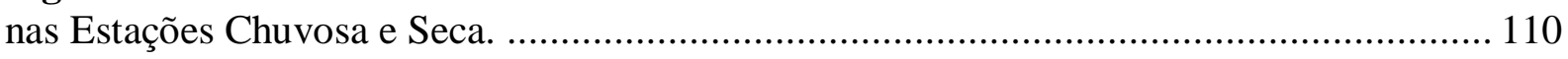

Figura 61. Granulometria dos sedimentos de fundo do Transecto 6 do Ribeirão das Cruzes nas Estações Chuvosa e Seca.

Figura 62. Granulometria dos sedimentos de fundo do Transecto 7 do Ribeirão das Cruzes nas Estações Chuvosa e Seca.

Figura 63. Diagrama ternário dos sedimentos na Estação Chuvosa................................. 112

Figura 64. Diagrama ternário dos sedimentos na Estação Seca. ..................................... 112 


\section{LISTA DE TABELAS}

Tabela 1. Fatores que interferem na forma de expressão dos processos erosivos do solo, relacionados às forças ativas.

Tabela 2. Fatores que interferem na forma de expressão dos processos erosivos do solo,

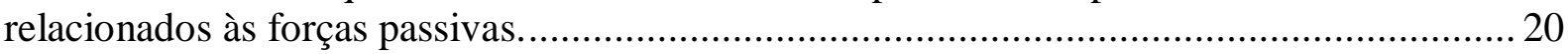

Tabela 3. Classificação dos tipos de erosão segundos seus agentes erosivos. ...................... 21

Tabela 4. Uso e ocupação do solo da Bacia do Baixo Tietê................................................ 38

Tabela 5. Coordenadas UTM dos pontos de coleta nas Estações Chuvosa e Seca................. 43

Tabela 5. Amostras de água - técnicas e referências metodológicas................................... 50

Tabela 6. Amostras de sedimentos de fundo - técnicas e referências metodológicas. ............ 60

Tabela 8. Mínimos e máximos das variáveis observadas na Estação Chuvosa..................... 64

Tabela 9. Mínimos e máximos das variáveis observadas na Estação Seca........................... 64

Tabela 10. Dados da medição da vazão do Transecto 1 ........................................................ 83

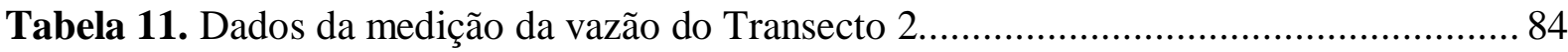

Tabela 12. Dados da medição da vazão do Transecto 3.................................................... 85

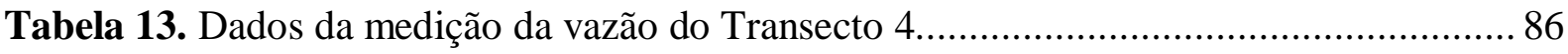

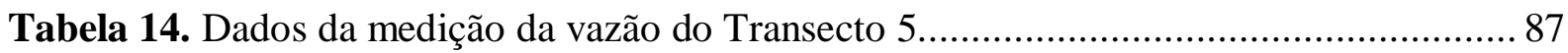

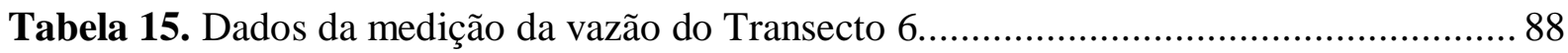

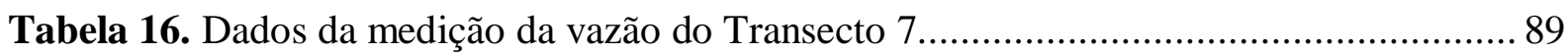

Tabela 17. Classificação dos sedimentos segundo a proposta de Flemming (2000)............ 113 


\section{SUMÁRIO}

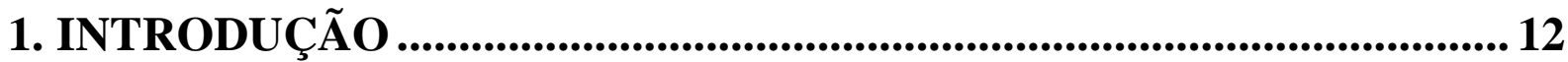

2. OBJETIVOS............................................................................................... 15

3. REVISÃO BIBLIOGRÁFICA ............................................................... 16

3.1. Origem e formação dos solos ...................................................................................... 16

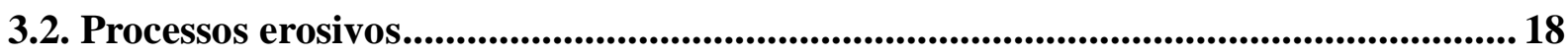

3.3. Erosão, agricultura e recursos hídricos ........................................................................... 27

3.4. Qualidade das águas e dos sedimentos .............................................................................. 28

4. MATERIAIS E MÉTODOS ..................................................................... 32

4.1. Caracterização da área de estudo ..................................................................................32

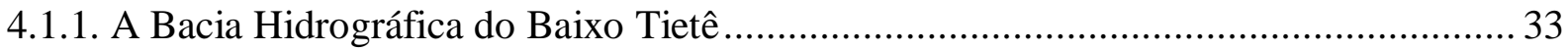

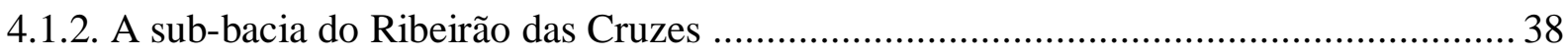

4.2. Detalhamento da metodologia ............................................................................................. 40

4.2.1. Compartimentação da bacia e campanhas de campo ………………………………... 40

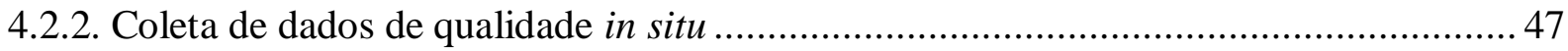

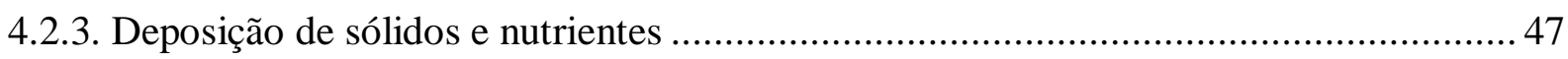

4.2.4. Medição da vazão nos transectos ............................................................................. 55

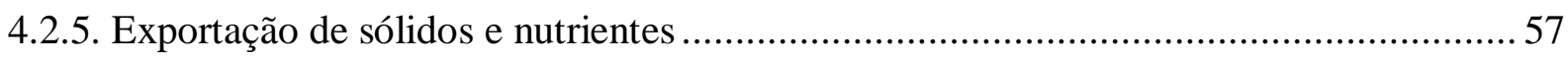

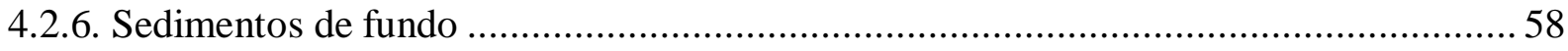

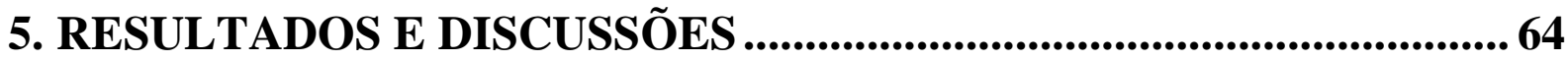

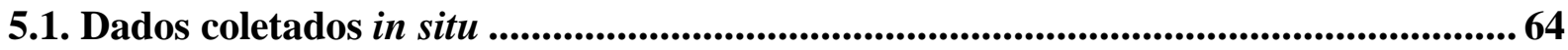

5.3. Deposição de sólidos e nutrientes.................................................................................. 73

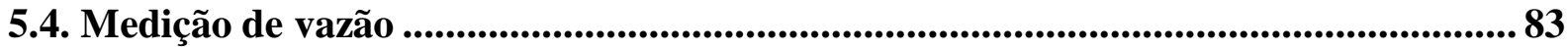

5.5. Exportação de sólidos e nutrientes .................................................................................91

5.6. Sedimentos de fundo .......................................................................................................... 101

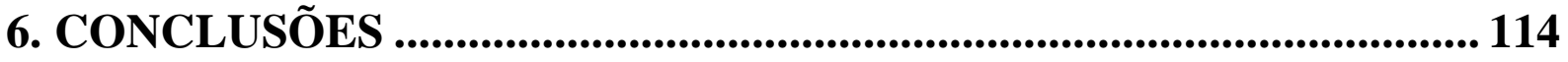

7. RECOMENDAÇÕES FINAIS .................................................................... 115

8. REFERÊNCIAS BIBLIOGRÁFICAS ................................................... 117 


\section{INTRODUÇÃO}

Há muito tempo se fala no crescimento econômico de maneira sustentável, mas pouco se vê de efetividade nas ações contra a degradação ambiental do solo, do ar e das águas, superficiais e subterrâneas.

A maneira pela qual a economia se expandiu nas últimas décadas, seja por meio do crescimento da indústria ou da atividade agropecuária, deveria ter adotado práticas mais eficazes para que este crescimento fosse sustentável ambientalmente.

Por exemplo, para fomentar este crescimento, grandes obras para construção de hidrelétricas se instalaram por todo o país para satisfazer as demandas por energia. Devido a isto, o simples fato de promover o barramento do corpo d'água, independentemente do seu uso futuro, é capaz de provocar a alteração do fluxo de água ao longo do canal causando importantes transformações nos ambientes aquáticos e terrestres do entorno.

Contudo, o barramento do fluxo da água também é benéfico, pois propicia os usos múltiplos do recurso hídrico, por exemplo, para abastecimento público, navegação, controle de cheias, reservação de água para produção de eletricidade, dentre outros usos.

A construção do barramento com a consequente formação do reservatório provoca importantes mudanças nas condições naturais de escoamento. Por exemplo, a diminuição da velocidade de escoamento reduz a capacidade de transportar sedimentos, o que favorece a deposição desses materiais e consequentemente o aumento da concentração de elementos químicos, dentre eles pesticidas, metais pesados, nutrientes, além de provocar o assoreamento dos corpos d'água.

Noutra ponta, especificamente relacionado à forma do desenvolvimento agrícola no Brasil, principalmente com a expansão das fronteiras agrícolas, predominou o uso massivo dos recursos naturais sem que se atentasse para os devidos planejamentos necessários, o que juntamente com as características do solo e do clima, ocasionou grandes perdas de solo agriculturável devido à erosão, carreando estes materiais sólidos para os corpos d'água.

Mas, além destes materiais sólidos, o escoamento superficial das águas pluviais leva consigo outros materiais, como matéria orgânica, insumos agrícolas e fertilizantes, o que, apesar de ser um processo natural, pode ter seu efeito maximizado devido às práticas incorretas na agricultura, contribuindo significativamente para o aumento da concentração de sólidos e nutrientes, principalmente em reservatórios. 
Somente relacionado ao acúmulo de materiais sólidos, importantes reservatórios do Brasil, como Itaipu e Tucuruí tiveram seu tempo para assoreamento total estimado em mais de 1000 anos, contudo este tempo é bem menor em locais específicos como nas áreas de remanso e delta, sendo que nestes lugares estima-se que em apenas 20 anos a navegação já poderá se apresentar prejudicada (CARVALHO et al, 2000a).

Como mencionado, o assoreamento é um fenômeno natural, devido ao carreamento de materiais pelas águas pluviais ou fluviais. Todavia, o assoreamento de um reservatório é computado tanto pela sedimentação que ocorre devido à redução na velocidade do fluxo da água quanto pelos processos erosivos que ocorrem em cada bacia de contribuição, pois configuram-se como significativas fontes de sedimentos.

Desta forma, conhecer a dinâmica dos processos de transporte, deposição e suspensão de sedimentos é de vital importância para a conservação, desenvolvimento e manejo destes ambientes (CARVALHO et al., 2000b).

A qualidade ambiental do corpo d'água, como um todo, é o resultado da situação de sua bacia de drenagem, e traz consigo informações das atividades que se desenvolvem e que se desenvolveram no solo do entorno. Neste sentido, o compartimento sedimento é capaz de integrar vários processos no meio aquático sendo seu estudo fundamental em análises ambientais.

Neste sentido, os estudos relacionados aos recursos hídricos não mais são focados em um único aspecto ou em um único ambiente. O que se observa nos últimos anos é o desenvolvimento de estudos integrados, mesmo quando relacionados aos recursos hídricos, uma vez que, por exemplo, sua qualidade é resultado das atividades que ocorrem em seu entorno.

Por isto cada vez mais tem-se utilizado a expressão "planejamento e gerenciamento integrado de recursos hídricos", buscando-se alternativas mais adequadas que agrupem o máximo possível de informações a respeito dos ambientes que se interagem. Assim, estudos integrados que envolvem análises de sedimentos, qualidade da água e uso e ocupação do solo são cada vez mais frequentes.

Isto somente foi possível devido o sucesso dos estudos que analisaram cada um dos aspectos desses estudos integrados independentemente e por final concluíram que as influências externas ao seu ambiente inicialmente especificado eram capazes de alterar significativamente suas variáveis. 
Até mesmo a vertente mais "matemática" dos estudos ambientais, isto é, a modelagem ambiental, já assume grandes compromissos com os estudos integrados, investindo tanto em pesquisa como no desenvolvimento de ferramentas computacionais capazes de integrar e analisar uma ampla gama de variáveis.

Neste sentido, os estudos de reservatórios, que são considerados como ambientes de transição entre um rio, por exemplo, e um lago, tem se revelado de grande interesse científico, principalmente em estudos relacionados às taxas de deposição e de exportação de materiais sólidos e de nutrientes que por vezes provocam o assoreamento do corpo d'água e podem propiciar a eutrofização. 


\section{OBJETIVOS}

O objetivo geral desse trabalho foi analisar a deposição e a exportação de sólidos e nutrientes na sub-bacia do Ribeirão das Cruzes, no município de Santo Antônio do Aracanguá, SP, na Unidade de Gerenciamento de Recursos Hídricos do Baixo Tietê (URGHI - 19), com a finalidade de discutir seus efeitos e fornecer dados para a gestão integrada dos recursos hídricos, envolvendo a análise do ambiente aquático e atentando-se para os processos que ocorrem no entorno e são capazes de afetar sua quantidade e a qualidade.

Os objetivos específicos do estudo foram:

$\checkmark$ Fragmentar a área da sub-bacia em compartimentos de acordo com características do uso e ocupação do solo predominantes nas bacias de contribuição e que pudessem influenciar na quantidade e qualidade de sólidos e nutrientes produzidos;

$\checkmark$ Analisar em cada compartimento, na sua margem direita, ao centro e na sua margem esquerda, as taxas de deposição de sólidos e nutrientes, utilizando-se para isto armadilhas de sedimentação, determinando assim os compartimentos que mais contribuem para o processo bem como os fatores associados;

Calcular a velocidade da água nos compartimentos e relacioná-la com as concentrações de sólidos e nutrientes, procedendo-se com a análise da exportação destes materiais, analisando inclusive a exportação para o Reservatório de Três Irmãos;

Analisar a granulometria e a concentração de nutrientes e matéria orgânica nos sedimentos de fundo de cada compartimento e relacionar esses dados com os processos de produção de sedimentos. 


\section{REVISÃO BIBLIOGRÁFICA}

\subsection{Origem e formação dos solos}

O solo pode ser considerado, dentre várias definições, como o material proveniente da decomposição das rochas, sendo esta decomposição provocada por agentes intempéricos (físicos, químicos ou biológicos), inclusive a ação humana. Independentemente do mecanismo de formação, o solo terá sua tipologia relacionada fundamentalmente com a rocha que deu origem aquele solo, também chamada de rocha mãe ou matriz (VARGAS, 1974).

Quando ocorre a decomposição da rocha matriz sem que haja alterações significativas na composição química dos seus elementos, denomina-se o processo de intemperismo físico. Nestas condições, os principais agentes que promovem este tipo de decomposição são as variações de temperatura (ciclos de congelamento e descongelamento) e e pressão (compressão e descompressão).

Já quando ocorre a decomposição da rocha com alteração química dos seus elementos, denomina-se o processo de intemperismo químico, sendo seu principal agente a água, destacando-se a hidrólise, a hidratação e a carbonatação.

O intemperismo biológico ocorre principalmente devido aos esforços mecânicos produzidos pelos vegetais através de suas raízes (TEIXEIRA et al., 2008).

$\mathrm{O}$ intemperismo químico possui um poder de degradação muito maior que o intemperismo físico. Por este motivo, solos gerados por processos de intemperismo químico tendem a ser mais profundos e mais finos do que aqueles formados por intemperismo físico, porém menos parecidos com a rocha mãe (VARGAS, 1974).

Após compreendido seu processo de formação, deve-se classificar o solo, e para isto pode-se utilizar de várias características, por exemplo, a origem, a evolução, a presença de matéria orgânica (ou não) e até mesmo sua estrutura. Mas, geralmente, os solos são classificados segundo duas grandes vertentes relativas ao processo geológico de formação, podendo ser classificados como: solos residuais e solos sedimentares.

Solos ditos residuais são aqueles que permanecem no local da decomposição da rocha de modo que a velocidade do processo intempérico de formação da rocha deve ser maior que a velocidade do agente erosivo de transporte/remoção do solo. Suas características dependem essencialmente da rocha matriz. 
Já solos sedimentares são aqueles que foram levados ao local onde se encontram atualmente por processos erosivos de transporte/remoção de solo, e suas características dependem do tipo de agente de transporte. Neste caso, solos sedimentares podem ser classificados como: eólicos, aluvionares, marinhos, fluviais, pluviais, glaciais ou coluvionares (TEIXEIRA et al., 2008).

A estrutura do solo é muito importante e vastamente utilizada para classificação e diz respeito ao tamanho relativo e a distribuição das partículas sólidas que o compõe. A análise específica da estrutura do solo é tratada pelo ensaio de granulometria.

Por este ensaio os solos podem ser divididos em dois grupos: solos finos, compostos basicamente por silte e argila; e solos grossos, compostos por areia, pedregulhos e pedras de mão (ABNT, 1984). Segundo essa classificação, os solos grossos são compostos por partículas com diâmetro maior que $0,074 \mathrm{~mm}$, tendo suas formas arredondadas, já os solos finos são aqueles que possuem dimensões menores que $0,074 \mathrm{~mm}$ e serão classificados como silte ou argila.

A NBR 6502 de 1995 - Rochas e Solos (ABNT, 1995) adota a seguinte escala granulométrica conforme representado na Figura 1.

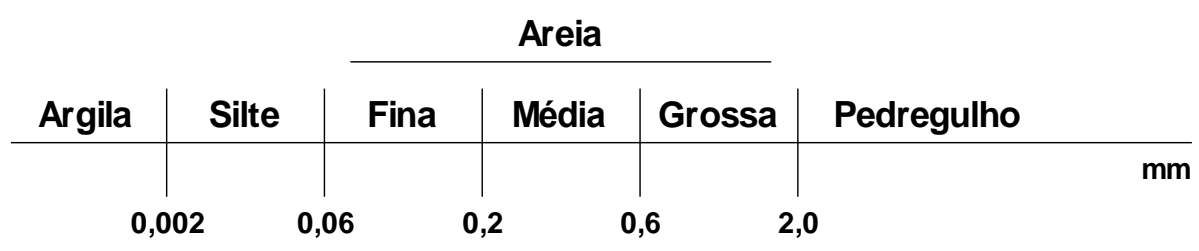

Figura 1. Escala granulométrica, segundo ABNT (1995).

Tratando especificamente de sedimentos, tanto transportados como já depositados sob o leito do curso d'água, existe o conceito a respeito da maneira como ocorre a deposição e como isto afeta a composição granulométrica dos sedimentos depositados.

Isto significa que, ao analisar a composição granulométrica dos sedimentos de fundo de um corpo d'água, e verificar que naquela porção predomina as frações grossas, ou seja, que predomina a fração areia sobre as frações de silte e de argila, infere-se que há aporte recente de sedimentos próximo ao local onde foi coletada a amostra de sedimentos. 
Já o contrário, quando predomina as frações de argila e silte sobre a fração areia, pode-se concluir que não há aporte de novos sedimentos no local, e que aquelas partículas que ali estão são resultados dos processos de sedimentação que ocorrem de montante para jusante, pois as partículas de maior tamanho relativo, areia e silte, sofreram deposição primeiramente.

Ou seja, verifica-se que há um padrão geral de sedimentação, principalmente em se tratando de reservatórios. À montante, nas cabeceiras, os rios que compõem o reservatório têm alta velocidade e fornecem grande parte do sedimentos ao reservatório, que por apresentar fluxo mais lento propicia a deposição destas partículas. As partículas maiores, sedimentam-se formando um delta, enquanto que as mais leves, como a argila, são depositadas ao longo do reservatório, mas podem também interagir e permanecem em suspensão por longos períodos (BONDURANT; LIVESEY ${ }^{1}$, 1973, apud BUFON, 2002).

\subsection{Processos erosivos}

Podem ser entendidos como o conjunto de processos que são responsáveis pela desagregação, dissolução, desgaste e, consequentemente, transporte dos materiais da crosta terrestre, segundo Vilar (1987).

Ainda, a remoção dos materiais da crosta terrestre pode ser derivada da ação combinada da força gravidade, da água, do vento e até dos organismos, assim como como os movimentos de massa (DAEE, 1990).

Weegel e Rustom (1992) afirmam que a desagregação e o transporte são consequência de processos naturais, dentre eles: precipitação, escoamento superficial, ventos e escorregamentos e também das atividades antrópicas que removem a cobertura superficial do solo.

Já Bertoni e Lombardi Neto (1999) definem erosão como "processo de desprendimento e arraste acelerado das partículas do solo causado pela água e pelo vento”.

E Lindsey e Marder (1999) citam a definição da Sociedade Americana de Testes e Materiais: "erosão é a perda progressiva do material original de uma superfície sólida devido a interação mecânica entre esta superfície e um fluído apresentando componentes múltiplos, ou choque de partículas líquidas e sólidas".

\footnotetext{
${ }^{1}$ BONDURANT, D. C.; LIVESEY, R. H. Reservoirs sedimentations studies. In: ACKERMANN, N. C. et al. (Ed.). Man-made lakes: their problems and environmental effects. Washington: American Go Physical Union, 1973. p. 364-367.
} 
Diante de tantas definições, pode-se até considerar a erosão como um processo constituído por três partes: destacamento, transporte e deposição das partículas. Sendo a energia para que estes processos ocorram, fornecida pelos agentes erosivos: água, vento, força da gravidade, reações químicas dentre outros (LAL, 2001).

Assim sendo, estão intrinsicamente relacionados os tipos de erosão com seus agentes erosivos, sendo estes, generalizadamente, considerados como elementos do meio físico que causam, ou afetam, a erosão, e são divididos em agentes ativos ou passivos (CARVALHO, 2008).

Agentes ativos são, por exemplo, a água, temperatura, insolação, vento, gelo, neve e ação de microrganismos, animais e seres humanos. Já agentes passivos são as características do terreno, por exemplo, topografia, gravidade, tipo de solo, cobertura vegetal, práticas de manejo e construções superficiais.

Na Tabela 1 são apresentados alguns fatores que interferem na forma de expressão dos processos erosivos relacionados às forças ativas, e na Tabela 2 relacionados às forças passivas, conforme Guy (1970).

Tabela 1. Fatores que interferem na forma de expressão dos processos erosivos do solo, relacionados às forças ativas.

\begin{tabular}{|c|c|c|}
\hline $\begin{array}{c}\text { Fatores } \\
\text { Principais }\end{array}$ & Elementos & Influência dos elementos na erosão do solo \\
\hline \multirow[t]{3}{*}{ Clima } & $\begin{array}{l}\text { Chuva, } \\
\text { escoamento } \\
\text { superficial } \\
\text { (intensidade } \\
\text { e duração) }\end{array}$ & $\begin{array}{l}\text { Promovida pela força do impacto das gotas da chuva que provoca } \\
\text { a quebra das partículas do solo (agregados), a movimentação e } \\
\text { dispersão destas partículas, além da compactação do solo com } \\
\text { consequente aumento do escoamento superficial. } \\
\text { Após atingida a taxa máxima de infiltração de água no solo, a } \\
\text { intensidade e duração do evento passam ser fundamentais para a } \\
\text { produção do escoamento superficial. }\end{array}$ \\
\hline & Temperatura & $\begin{array}{l}\text { Alternância entre congelamento e degelo: provoca a expansão do } \\
\text { solo, aumenta o conteúdo da mistura e diminui sua coesão, desta } \\
\text { forma, o deslocamento, dispersão e o transporte são facilitados. }\end{array}$ \\
\hline & Vento & $\begin{array}{l}\text { Deslocamento devido a diferença de pressão e impacto do vento } \\
\text { com a superfície. }\end{array}$ \\
\hline Gravidade & & Perda de massa. \\
\hline
\end{tabular}

Fonte: Modificado de Guy (1970). 
Tabela 2. Fatores que interferem na forma de expressão dos processos erosivos do solo, relacionados às forças passivas.

\begin{tabular}{|c|c|c|}
\hline $\begin{array}{l}\text { Fatores } \\
\text { Principais }\end{array}$ & Elementos & Influência dos elementos na erosão do solo \\
\hline \multirow{6}{*}{ Do solo } & \multirow{6}{*}{$\begin{array}{l}\text { Propriedades } \\
\text { da massa }\end{array}$} & $\begin{array}{l}\text { Granulometria: afeta a força requerida para promover o } \\
\text { deslocamento e o transporte. }\end{array}$ \\
\hline & & $\begin{array}{l}\text { Estratificação: um substrato com baixa porosidade e } \\
\text { permeabilidade controla a taxa de infiltração entre camadas. }\end{array}$ \\
\hline & & $\begin{array}{l}\text { Porosidade: determina a capacidade de armazenamento do solo } \\
\text { afetando a infiltração e o escoamento. }\end{array}$ \\
\hline & & $\begin{array}{l}\text { Permeabilidade: determina a taxa de percolação afetando, } \\
\text { também, a infiltração e o escoamento. }\end{array}$ \\
\hline & & $\begin{array}{l}\text { Umidade: reduz a coesão prolongando o tempo de erosão a partir } \\
\text { do aumento do período de precipitação. }\end{array}$ \\
\hline & & $\begin{array}{l}\text { Suscetibilidade ao congelamento: determina a intensidade de } \\
\text { formação de gelo, afetando a porosidade, o conteúdo da mistura e } \\
\text { promovendo uma redução da resistência do solo. }\end{array}$ \\
\hline & & Orientação: determina a efetividade das forças climáticas. \\
\hline Topografia & Declividade & $\begin{array}{l}\text { Comprimento da rampa: afeta a quantidade ou profundidade do } \\
\text { escoamento, por sua vez afetando a turbulência e afetando assim } \\
\text { a erosão e o transporte de sedimentos. }\end{array}$ \\
\hline \multirow[b]{2}{*}{$\begin{array}{l}\text { Cobertura } \\
\text { do solo }\end{array}$} & $\begin{array}{l}\text { Cobertura } \\
\text { vegetal }\end{array}$ & $\begin{array}{l}\text { Viva, ou morta, protege a superfície do solo por interceptar as } \\
\text { gotas de chuva diminuindo a erosão devido a redução da } \\
\text { velocidade do escoamento superficial; aumenta a porosidade do } \\
\text { solo; e no caso de vegetação viva, aumenta a capacidade do solo } \\
\text { de reter umidade a partir do processo de transpiração. }\end{array}$ \\
\hline & $\begin{array}{l}\text { Cobertura } \\
\text { não vegetal }\end{array}$ & $\begin{array}{l}\text { Superfícies abertas resultam em menor proteção e } \\
\text { consequentemente maior aumento da erosão devido ao impacto } \\
\text { das gotas, reduzindo a infiltração, aumentando o escoamento } \\
\text { superficial e maximizando a erosão. Superfícies pavimentadas } \\
\text { garantem máxima proteção do solo, entretanto geram alto } \\
\text { escoamento superficial. }\end{array}$ \\
\hline
\end{tabular}

Fonte: Modificado de Guy (1970). 
Sabendo-se como as forças ativas e passivas podem afetar os processos erosivos, Carvalho (2008) propõe uma classificação dos principais tipos de erosão segundo seus agentes erosivos, conforme apresentado na Tabela 3.

Tabela 3. Classificação dos tipos de erosão segundos seus agentes erosivos.

Agente erosivo

Erosão devido a sais solúveis ou de minerais

Eólica

Fluvial

Hídrica superficial

Remoção em massa

Provocado por ação humana ou de animais

Eventos extremos
Decomposição de materiais solúveis pela ação da água.

Poeira, transporte pelo ar, transporte na superfície.

Escavação, erosão de margem, erosão de leito.

Erosão pluvial, erosão laminar, erosão em sulcos ou ravinas, erosão por escoamento difuso intenso, erosão por escoamento concentrado (voçorocas).

Rastejo, rastejamento ou cripe, solifluxão, deslizamento de terra ou desprendimento, escorregamento superficial ou ruptura de talude, escorregamento profundo.

Em obras diversas, por desmatamentos, na agricultura por aração do solo, na pecuária devido ao pisoteio do gado.

Por enchentes, por terremotos, por vulcanismos, por tornados, por variabilidade climática.

Fonte: Modificado de Carvalho (2008).

\section{$\checkmark$ Erosão eólica}

Neste tipo de erosão, as forças do vento provocam a movimentação e desprendimento das partículas do solo. No geral, quando o solo está muito seco, as partículas perdem a coesão e tornam-se mais vulneráveis ao agente erosivo.

A expressividade da erosão eólica depende de vários fatores: tamanho das partículas do solo, textura, rugosidade, cobertura da superfície do terreno; velocidade e turbulência do vento (CARVALHO, 2008). 


\section{$\checkmark$ Erosão fluvial}

Os processos erosivos que ocorrem em corpos de água são praticamente oriundos da erosão do leito devido às forças da correnteza do próprio corpo de água ou das margens, também devido à correnteza, mas também pela ação das ondas e desbarrancamento das margens quando estas se encharcam pelas ondas ou marés, processando-se de forma contínua. O material desprendido, chamado de aluvião, é então transportado pelas águas.

\section{$\checkmark$ Erosão por remoção de massa}

Este tipo de erosão corresponde ao movimento de quantidade significativa de material sob influência tanto da ação da gravidade quanto da saturação da concentração de água no solo. Nesta combinação, o solo pode se tornar plástico, ou até mesmo líquido, perdendo suas forças internas de coesão e, assim, por meio da ação da gravidade, pode sofrer deformação.

Os movimentos de massa podem ser lentos (rastejo ou solifluxão) ou rápidos (desprendimento, escorregamento superficial ou escorregamento profundo).

O rastejo caracteriza-se pelo movimento lento das camadas superiores do solo e rochas sobre as camadas mais profundas. Sua expressão no ambiente pode ser facilmente notada, por exemplo, pela deformação provocada em árvores. A solifluxão também é um movimento lento de massa de solo e rochas, mas ocorre pela saturação de água, principalmente em eventos de chuvas persistentes.

Os movimentos rápidos geralmente envolvem grande quantidade de material, e são mais comuns em encostas.

\section{$\checkmark$ Erosão hídrica superficial}

A água representa a maior parte dos processos erosivos, seja, por exemplo, por meio da força das gotículas da chuva que caem sobre a superfície terrestre e provocam o desprendimento das partículas do solo descoberto, também chamado de salpicamento, ou devido à própria força de escoamento das águas pluviais e fluviais (GUY, 1970).

Por isto, a chuva é considerada como a mais dinâmica e importante força do meio ambiente capaz de influenciar no processo de erosão (COOK, 1936). Numa chuva sob terreno com erodibilidade alta, os impactos das gotas provocam suspensão das partículas fazendo com que elas se movimentem para jusante da rampa devido à ação da força da gravidade (GUY, 1970). Ainda, num mesmo evento, a energia dissipada pelas gotas da chuva provocam a 
compactação do solo, diminuindo a infiltração, aumentando o escoamento superficial e, portanto, aumentando a erosão (EDWARDS e GLYSSON, 1998).

A erodibilidade de um solo relaciona-se com as características físicas que afetam sua resistência à erosão (COOK, 1936).

A capacidade da chuva causar erosão é chamada de erosividade. Se a chuva for mais branda, mesmo que ocorra por várias horas, a maior parte da água se infiltra no solo, ocorrendo pouca desagregação de solo. Neste caso, a chuva é de baixa erosividade. Entretanto, se o mesmo volume de chuva ocorrer em poucos minutos, como em uma tempestade, a desagregação do solo será maior e grande parte da água escoará rapidamente pela superfície sob forma de enxurrada. Neste caso a chuva é considerada de alta erosividade.

Contudo, há outros fatores que influenciam na erosão do solo, como a energia do impacto das gotas da chuva. Ainda, deve-se considerar a capacidade de infiltração e armazenamento do solo, a declividade e o comprimento da rampa. Desta forma, por exemplo, mesmo um solo tendo alta erodibilidade, o efeito causado pode ser atenuado caso o solo tenha alta capacidade de infiltração (LOUREIRO, 2008).

Das varias situações possíveis, pode-se subdividir a erosão hídrica superficial, quando prioritariamente se manifesta como erosão pluvial, como: erosão por escoamento difuso, laminar e por escoamento concentrado.

A erosão laminar ocorre durante as fortes precipitações, quando o solo encontra-se saturado, ou após saturar o solo, produzindo um desgaste suave e uniforme da camada superficial (CARVALHO, 2008) e ocorre geralmente em três etapas: desagregação, quando as partículas se desprendem devido ao impacto das gotas da chuva na superfície do solo; transporte dessas partículas desagregadas principalmente por meio da água que escoa superficialmente; e deposição, quanto estas partículas desagregadas sedimentam em vales ou leitos de rios, a partir de então, chamadas de sedimentos (EDWARDS e GLYSSON, 1998).

Erosão por escoamento difuso, ou também conhecida como erosão em sulcos ou ravinas, é uma forma de erosão que ocorre em filetes de água que se dividem, espalham e infiltram-se após pouca distância, depositando o material transportado. Sulcos são pequenas incisões na superfície, semelhante à filetes muito rasos (até $0,5 \mathrm{~m}$ de profundidade) e perpendiculares às curvas de nível, desenvolvendo-se em áreas nas quais a erosão laminar é mais intensa (PROIN/CAPES e UNESP/IGCE, 1999). A Figura 2 ilustra uma erosão em sulcos. 


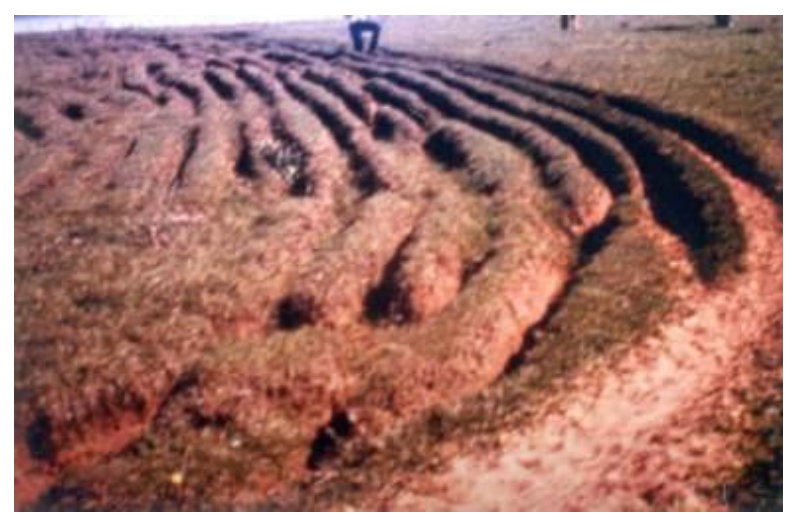

Figura 2. Exemplo de erosão em sulcos.

Fonte: (PROIN/CAPES e UNESP/IGCE, 1999).

Ravinas apresentam profundidade superior a $0,5 \mathrm{~m}$, diferentemente de sulcos e não são corrigidas com operações normais de preparo do solo. Possui forma reta, alongada e estreita, raramente se ramifica e não atinge o nível do lençol freático. Apresentam perfil em "V", ocorrendo entre eixos de drenagem associados à formas pré-existentes no terreno (estradas, trilhas de gado e carreadores) (PROIN/CAPES e UNESP/IGCE, 1999). A Figura 3 ilustra uma erosão em ravinas.

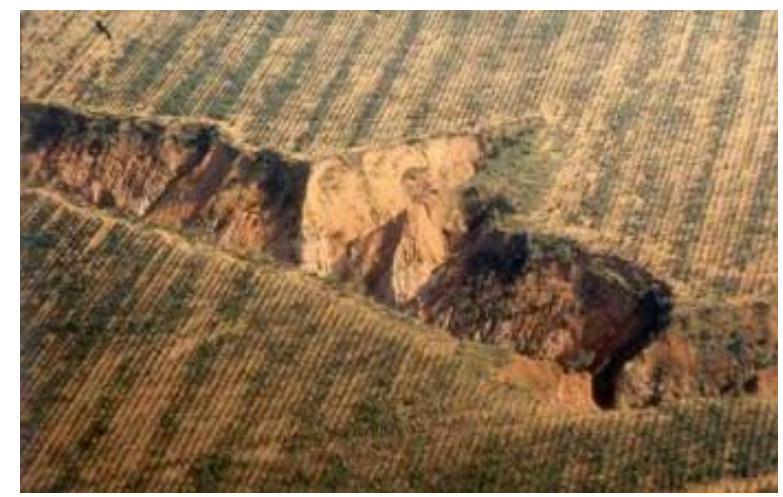

Figura 3. Exemplo de erosão em ravinas.

Fonte: (PROIN/CAPES e UNESP/IGCE, 1999).

Segundo Rodrigues (1982), voçorocas são ravinas profundas que se desenvolvem em sedimentos, solos, taludes naturais e artificiais, preferencialmente ao longo de uma linha de drenagem, conforme ilustrado pela Figura 4, cujas formas são variadas e de difícil controle (IWASA e PRANDINI, 1980; CANIL et al., 1995). 
Em geral, o fenômeno se caracteriza pela alta velocidade de escoamento (quando comparado à velocidade de escoamento da água nas erosões do tipo sulco e ravina) e remoção rápida do material de forma que não haja o desenvolvimento de vegetação.

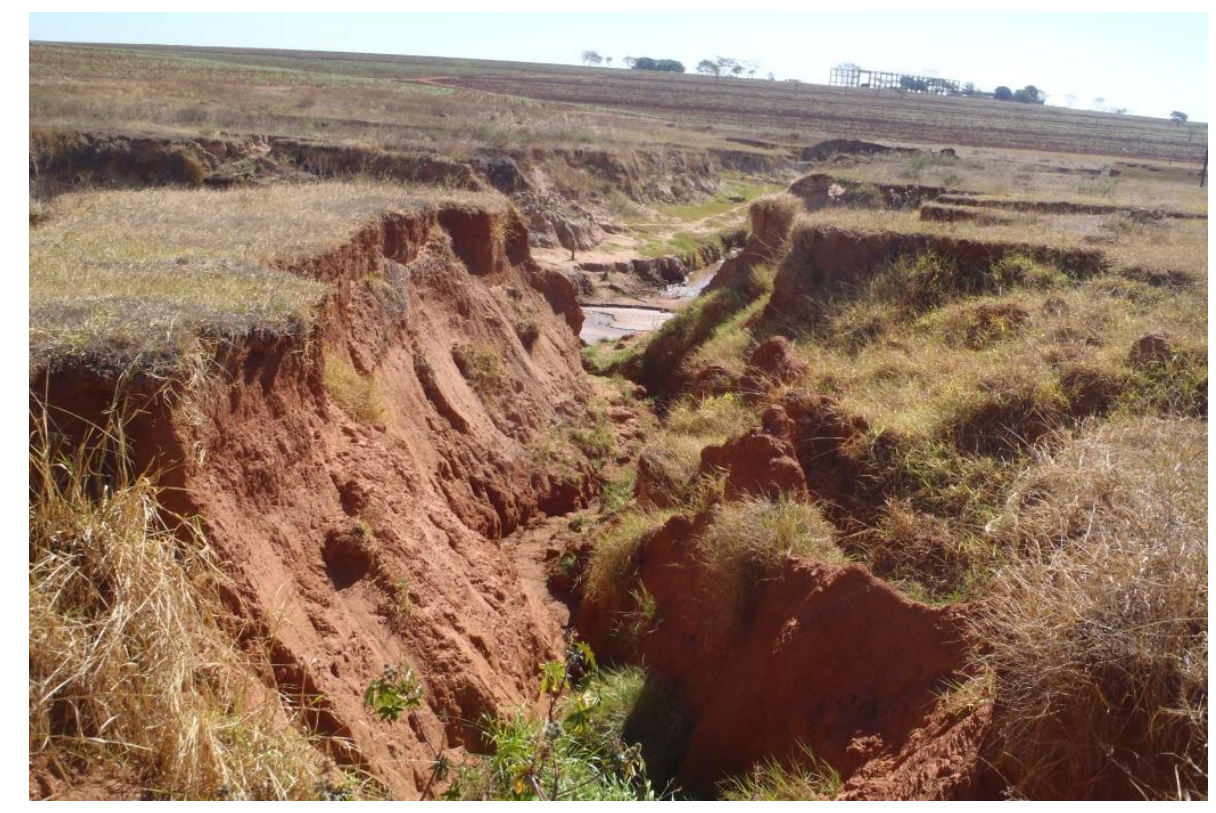

Figura 4. Exemplo de erosão em voçorocas, na sub-bacia do Ribeirão das Cruzes, Baixo Tietê (SP).

Neste sentido, as voçorocas se constituem como a forma de erosão mais complexa e mais destrutiva dentre as erosões lineares (sulcos, ravinas e voçorocas), combinando a ação das águas de escoamento superficial e sub-superficial, podendo desenvolver processos de piping (erosão interna), escorregamentos e corridas (PICHLER, 1953; BIGARELLA e MAZUCHOSKI, 1985; PONÇANO e PRANDINI, 1987; DAEE, 1990; CERRI et al., 1997).

Segundo Rodrigues e Vilar (1984), o aparecimento das voçorocas deve-se ao escoamento superficial da água, enquanto que o avanço lateral, inclusive arrastando as partículas do maciço, deve-se ao escoamento sub-superficial.

A voçoroca, a partir de sua formação à extinção quando passa por quatro estágios (MACIEL FILHO, 1994):

- Formação de sulcos e neste estágio pode ser considerada como uma ravina;

- Formação dos saltos, ou seja, aprofundamento da voçoroca;

- Alargamento e definição do nível base da erosão, formação do fundo plano (neste estágio é evidente a contribuição da água sub-superficial no processo erosivo); 
- Extinção da voçoroca, com técnicas de engenharia de estabilização de taludes e drenagem e implantação de vegetação para proteção da camada superior do terreno.

As formas geológicas ainda devem ser consideradas como eventos capazes de influenciar no processo erosivo, por exemplo, as encostas convexas, por isso, coletoras e dispersoras, estão intimamente susceptíveis a formação de voçorocas (PONÇANO e PRANDINI, 1987).

O conceito de voçoroca urbana e rural foi introduzido primeiramente por Iwasa e Prandini (1980), que as definem como:

- Voçorocas urbanas: aquelas que ocorrem em cidades instaladas em terrenos com baixa resistência à erosão, nos quais, quando não pavimentados, apresentam formação de ravinas onde as próprias ruas servem de adutora para as águas das chuvas captadas pelos telhados das casas, além do runoff local;

- Voçorocas rurais: desenvolvem-se em pastagens e culturas onde a cobertura vegetal é deficiente, muito provavelmente devido ao manejo inadequado do solo, acredita-se também que suas formações são resultados do ravinamento iniciado ao longo dos anos por meio das valas de demarcação, trilhas e, até mesmo, linhas de plantio.

Suas dimensões são as mais variadas possíveis e, segundo Pichler (1953), suas profundidades podem variar de 15 a $30 \mathrm{~m}$, sendo que, em comprimento podem atingir centenas de metros. Assim, por se constituírem processos erosivos complexos, voçorocas devem merecer cuidados diferenciados em seu tratamento e seus estudos são de fundamental importância (SALOMÃO, 1992). 


\subsection{Erosão, agricultura e recursos hídricos}

Juntamente com as características do solo e também do clima, que no caso do Brasil é altamente influenciado pelas intensas precipitações ou também chamadas de chuvas torrenciais, e devido à maneira como se desenvolveu a agricultura no país, ou seja, utilizando-se massivamente os recursos naturais sem o devido planejamento, ocorreram grandes perdas de solo por erosão, carreando estes materiais para os corpos d'água nas adjacências, além de carrear matéria orgânica e insumos agrícolas, principalmente fertilizantes, contribuindo significativamente para o aumento da concentração de sólidos e nutrientes (VANZELA et al., 2010).

Em se tratando da solução para problemas decorrentes de fontes de poluição de origem pontual, apesar de onerosos, são relativamente fáceis de serem aplicados e já tiveram seus resultados comprovados. Entretanto, a erosão do solo, devido a sua dinâmica de expressão, é considerada como uma das principais fontes de poluição de origem não pontual, ou difusa, causando poluição dos recursos hídricos superficiais (BRAMORSKI, 2007).

Fontes difusas de poluição têm por característica a sazonalidade e o potencial de atingir grandes áreas, e isto está muito evidente quando relacionado à agricultura. Para estes casos, a solução dos problemas requer o manejo adequado da bacia de drenagem como um todo, adotando ações mitigadoras bem específicas (SIMÔES, 2001).

O fato é que, impulsionados pela possibilidade de exportar os produtos da safra a preços melhores do que no próprio mercado interno, visando a obtenção de uma produtividade agrícola a níveis considerados ótimos, por muitas vezes torna-se necessário a aplicação de corretivos no solo. Estes corretivos têm por finalidade adequar as características daquele solo às necessidades do cultivo que será plantado, ou que já se encontra em desenvolvimento e requerem complementação de nutrientes.

$\mathrm{Na}$ maioria das vezes, a principal característica a ser adequada é a fertilidade do solo, tornando-se necessário a aplicação de compostos basicamente constituídos por nitrogênio e fósforo.

Como dito, a aplicação destes fertilizantes têm por objetivo suprir as necessidades das culturas, contudo, sem um manejo adequado acabam sendo aplicados acima da capacidade de absorção pelas plantas, ou até mesmo, por um equívoco técnico, fora da região ótima de absorção pelas raízes.

Isto, aliado a perda iminente relacionada ao escoamento superficial das águas pluviais, geram problemas como a contaminação e eutrofização dos recursos hídricos (SILVA 
e CRESTANA, 2004), sendo a erosão em áreas agrícolas considerada como uma das principais causas da perda da qualidade dos recursos hídricos nos Estados Unidos (EILERS, 2003).

Todavia, a percepção dos processos erosivos em sua totalidade é difícil, senão impossível, de ser acompanhada na escala de vida humana (CARVALHO et al., 2000b).

Assim, é necessário delimitar um sistema para estudo destes processos, por isto os estudos sedimentológicos, assim como hidrológicos, adotam a bacia hidrográfica como unidade de planejamento.

No entanto, a produção dos sedimentos envolve não somente os processos de erosão, a movimentação das partículas sólidas no meio aquático e a deposição destas. Por isto, segundo Edwards e Glysson (1998), estudos deste tipo devem contemplar:

- a avaliação da produção dos sedimentos segundo as condições naturais do meio ambiente, como solo, clima, runoff, topografia, cobertura do solo e área de drenagem;

- a avaliação da produção de sedimentos segundo o uso e ocupação do solo;

- a taxa de transporte de sedimentos em rios;

- a granulometria das partículas transportadas;

- o relacionamento das características químicas dos sedimentos com a qualidade da água e consequentemente com a biota, tanto aquática quanto terrestre.

\subsection{Qualidade das águas e dos sedimentos}

Especificamente no Estado de São Paulo, as bacias hidrográficas há muito anos vem sendo expostas à contaminantes de origem industrial, doméstica e agrícola, sendo que grandes áreas foram contaminadas de forma intencional ou acidental (COSTA, 2001).

Em pequenas concentrações elementos como o magnésio, ferro, zinco, manganês, cobalto, cobre e molibdênio são essenciais aos seres vivos e têm função essencial no metabolismo de organismos aquáticos. Entretanto, outros metais como o mercúrio, chumbo, prata, cromo, níquel e estanho não têm função biológica conhecida e são tóxicos a muitos organismos (ESTEVES, 1998).

Por isto, lançamentos de poluentes metálicos, na maioria das vezes oriundos de atividades industriais ou de mineração, têm contribuído, por exemplo, para elevação das concentrações de metais pesados nos ambientes aquáticos (MOZETO, 2001). 
Metais pesados podem se acumular em organismos e em sedimentos, associados às argilas e à matéria orgânica, por exemplo. Amostras de sedimentos podem indicar, além da qualidade atual, diferenças na sua composição ao longo do tempo (MASSUTTI, 1999), por meio da avaliação das amostras indeformadas do sedimento de fundo e por processos de datação (geocronologia). Diferenças na concentração de um contaminante a diferentes profundidades numa amostra de sedimento são testemunhos das alterações históricas ocorridas no ecossistema devido ao acumulo dos contaminantes (DIN, 1992).

Desta forma, é evidente a importância da análise dos sedimentos nos ecossistemas aquáticos, especialmente quando se constituem como depósitos de contaminantes metálicos, de matéria orgânica e nutrientes (DORNFELD et al., 2002).

Não obstante, a introdução de nutrientes, provocando a alteração da concentração no ambiente aquático, é capaz do promover significantes transformações. Por exemplo, o simples fato de poder haver a conversão do sistema lótico para lêntico pode acelerar o processo de eutrofização, uma vez que se reduz a velocidade de escoamento da água, aumenta-se a acumulação dos nutrientes, podendo desencadear, em um primeiro momento, o desenvolvimento de macrófitas e fitoplâncton.

$\mathrm{O}$ nitrogênio entra em contato com os ambientes aquáticos (lagos, rios e reservatórios, por exemplo) essencialmente por dissolução e lixiviação dos solos e é reciclado infinitamente pela decomposição dos organismos que o assimilam em seu ciclo de vida, sendo indispensável ao desenvolvimento dos organismos fotossintetizadores, principalmente sob a forma de nitratos (ESTEVES, 1998), além de desempenhar o papel de fator limitante para organismos autótrofos. Num ambiente com potencial de oxi-redução baixo e ausência de oxigênio os nitratos podem ser substituídos por seus sais menos estáveis, o nitrito e a amônia.

A erosão contribui para a perda de nitrogênio do solo, e de acordo com Bright (2003), as atividades humanas são responsáveis pela duplicação da quantidade de nitrogênio liberado, cerca de 350 milhões de toneladas anuais. Segundo Bramorski (2004), é "evidente a importância do estudo dos estoques de nutrientes nas camadas sedimentares".

A concentração de nutrientes na água e nos sedimentos varia com sua concentração no solo (DANIEL et al., 1997) sendo altamente influenciada pelas adubações, cobertura e manejo do solo (SEGANFREDO et al., 1997; SCHICK et al., 2000).

Procedimentos conservacionistas de manejo do solo tendem a reduzir as perdas de água e sedimentos, o que diminui as perdas totais de nutrientes por erosão (BERTOL, 1994; KING et al., 1996; SCHICK et al., 2000). 
A aplicação de adubos nas lavouras, durante longo período de tempo, tende a aumentar a concentração de nitrogênio e fósforo na superfície do solo (ELTZ et al., 1989; SCHICK et al., 2000). Isto proporciona aumento das concentrações desses nutrientes tanto na água quanto nos sedimentos presentes na enxurrada e que por final acabam se depositando no leito dos corpos d'água da bacia de drenagem (POTE et al., 1996; SCHICK et al., 2000).

Dentre os vários elementos químicos que podem ser encontrados nos ambientes aquáticos, o nitrogênio destaca-se por se relevante no metabolismo do ecossistema como um todo, pois participa da formação das proteínas. Desta forma, quando está disponível apenas em baixas concentrações pode atuar como um fator limitante na produção primária do ecossistema aquático (ESTEVES, 1998).

O nitrogênio pode ser encontrado de várias formas no meio ambiente, a saber: nitrato, nitrito, amônia, amônio, óxido nitroso, nitrogênio molecular, nitrogênio orgânico dissolvido, nitrogênio orgânico particulado, dentre outras formas.

No entanto, o nitrato é considerado como mais importante, pois constitue-se como a principal fonte de alimento para os produtores primários, ou seja, é um elemento indispensável, por exemplo, ao crescimento de algas, mas, em excesso, pode ocasionar um exagerado desenvolvimento desses organismos, fenômeno chamado de eutrofização (ESTEVES, 1998).

O nitrito, por ser instável na presença de oxigênio, é encontrado em quantidades muito pequenas no ambiente aquático, mas sua presença indica a poluição do meio ambiente proveniente de cargas orgânicas, sendo também relacionado à decomposição biológica devido à ação de microrganismos sobre o nitrogênio amoniacal (ESTEVES, 1998).

Experimentos realizados por Daniel et al. (1997) e Schick et al. (2000) indicaram que as concentrações de fósforo na camada superficial do solo apresentaram correlação linear e positiva com as concentrações desse elemento nos sedimentos presentes nas águas de enxurrada.

Pote et al. (1996) também observaram que doses crescentes de fósforo aplicado no solo correlacionaram-se linear e positivamente com os consequentes aumentos nas concentrações do elemento na água da enxurrada, resultando em aumentos das perdas totais desse elemento na erosão hídrica.

Embora o fósforo solúvel na água represente uma pequena fração do fósforo total perdido por erosão hídrica, a forma solúvel desse elemento é mais prontamente biodisponível do que aquela ligada aos sedimentos (McISAAC et al., 1995), razão esta que pode causar impacto imediato nos locais de deposição, fora do local de origem da erosão. 
O fósforo, juntamente com o nitrogênio, se constitui como os principais elementos limitantes da produtividade primária. Ainda, este é pode ser considerado como responsável pela eutrofização dos ambientes aquáticos, sendo suas principais fontes: dissolução de compostos do solo; decomposição da matéria orgânica, esgotos domésticos e industriais; fertilizantes; detergentes; excrementos de animais.

Pode ser encontrado no ambiente sob as seguintes formas: fosfato particulado, fosfato orgânico dissolvido e fosfato inorgânico dissolvido, ou, mais comumente reconhecido como ortofosfato, considerado como a forma mais importante por se a mais facilmente assimilada pelos vegetais aquáticos.

Deve-se considerar que, em lagos tropicais, devido as elevadas temperaturas da água o metabolismo dos organismos sobre aumento considerável e assim o ortofosfato é mais rapidamente assimilado, de forma que sua concentração no ambiente é geralmente baixa (ESTEVES, 1998). 


\section{MATERIAIS E MÉTODOS}

\subsection{Caracterização da área de estudo}

Considerando o princípio que a água é um bem público, dotado de valor econômico, e considerando o histórico de uso degradador, sem quaisquer responsabilidades a respeito de sua qualidade e quantidade, bem como o modelo de crescimento econômico adotado pelo país, no qual a expansão da fronteira agrícola sem as devidas técnicas propiciou grandes perdas de solo por erosão, verifica-se que as políticas norteadoras adotam uma sistemática de gestão descentralizada dos recursos hídricos, relacionada intimamente com as peculiaridades de cada uma de suas bacias hidrográficas.

Neste intuito, com abrangência nacional, segundo o disposto na Resolução n. ${ }^{\circ} 32$, de 15 de outubro de 2003, do Conselho Nacional de Recursos Hídricos - CNRH (CNRH, 2003), o território foi subdividido em grandes regiões hidrográficas, também conhecidas como Regiões Hidrográficas Brasileiras.

Por esta divisão, o território nacional ficou subdividido nas seguintes Regiões Hidrográficas: Amazônica, Nordeste Ocidental, Nordeste Oriental, do Paraíba, do Paraguai, do Tocantins/Araguaia, do Atlântico Leste, do São Francisco, do Paraná, do Atlântico Sudeste, do Uruguai e do Atlântico Sul, conforme pode ser representado pela Figura 5.

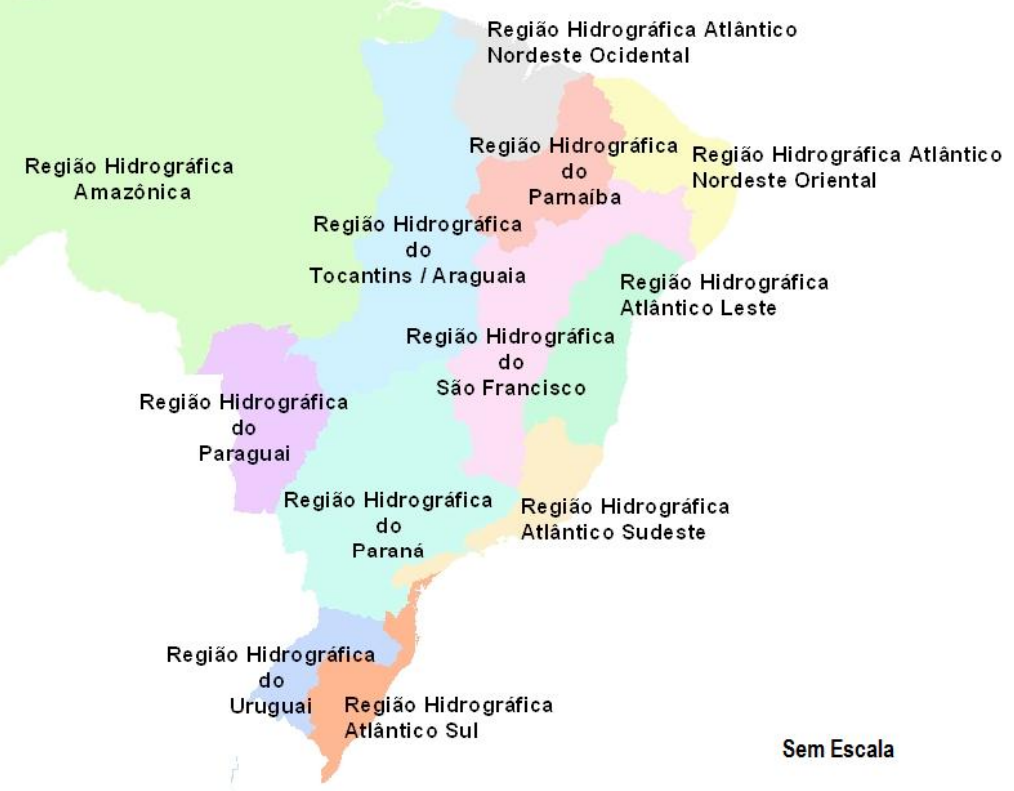

Figura 5. Divisão hidrográfica do território nacional.

Fonte: CNRH (2003). 
Em consonância com a divisão estabelecida pelo CNRH, os Estados também realizaram a divisão hidrográfica de seus territórios para fins de gerenciamento dos recursos hídricos.

Por exemplo, o Estado de Minas Gerais foi subdividido em 36 regiões hidrográficas, o Estado de São Paulo, em 22 e o Estado do Paraná, em 15 regiões.

Mas vale ressaltar que o pioneirismo de alguns Estados em relação ao tema serviu de subsídios para a divisão estabelecida pela União, e não o contrário.

\subsubsection{A Bacia Hidrográfica do Baixo Tietê}

Em 30 de dezembro de 1991 foi publicada a Lei n. ${ }^{\circ}$ 7663, que instituiu a Política Estadual de Recursos Hídricos - PERH do Estado de São Paulo, bem como o Sistema Integrado de Gerenciamento de Recursos Hídricos - SIGRH.

Nesta Lei, ficou estabelecido em seu Artigo 20 que no Plano Estadual de Recursos Hídricos deveria constar a divisão hidrográfica do Estado em unidades hidrográficas que permitissem o gerenciamento descentralizado dos recursos hídricos (SÃO PAULO, 1991).

Assim, em 27 de dezembro de 1994, com a publicação da Lei Estadual n. ${ }^{\circ}$ 9034, que dispõe sobre o Plano Estadual de Recursos Hídricos, ficou aprovado por meio do Artigo $4^{\circ}$ a divisão do Estado de São Paulo em 22 Unidades Hidrográficas de Gerenciamento de Recursos Hídricos - UGRHI, cuja divisão deveria ser adotada pelos órgãos e entidades do Estado, participantes do Sistema Integrado de Gerenciamento de Recursos Hídricos, quando da proposição de planos e programas de utilização, recuperação, proteção e conservação dos recursos hídricos (SÃO PAULO, 1994).

Neste interim, de um modo generalizado, a área de estudo deste trabalho localizase na Bacia Hidrográfica do Baixo Tietê, que corresponde à Unidade de Gerenciamento de Recursos Hídricos n. ${ }^{\circ} 19$ (UGRHI 19), situada geograficamente no noroeste do Estado de São Paulo, conforme pode ser representado na Figura 6. 


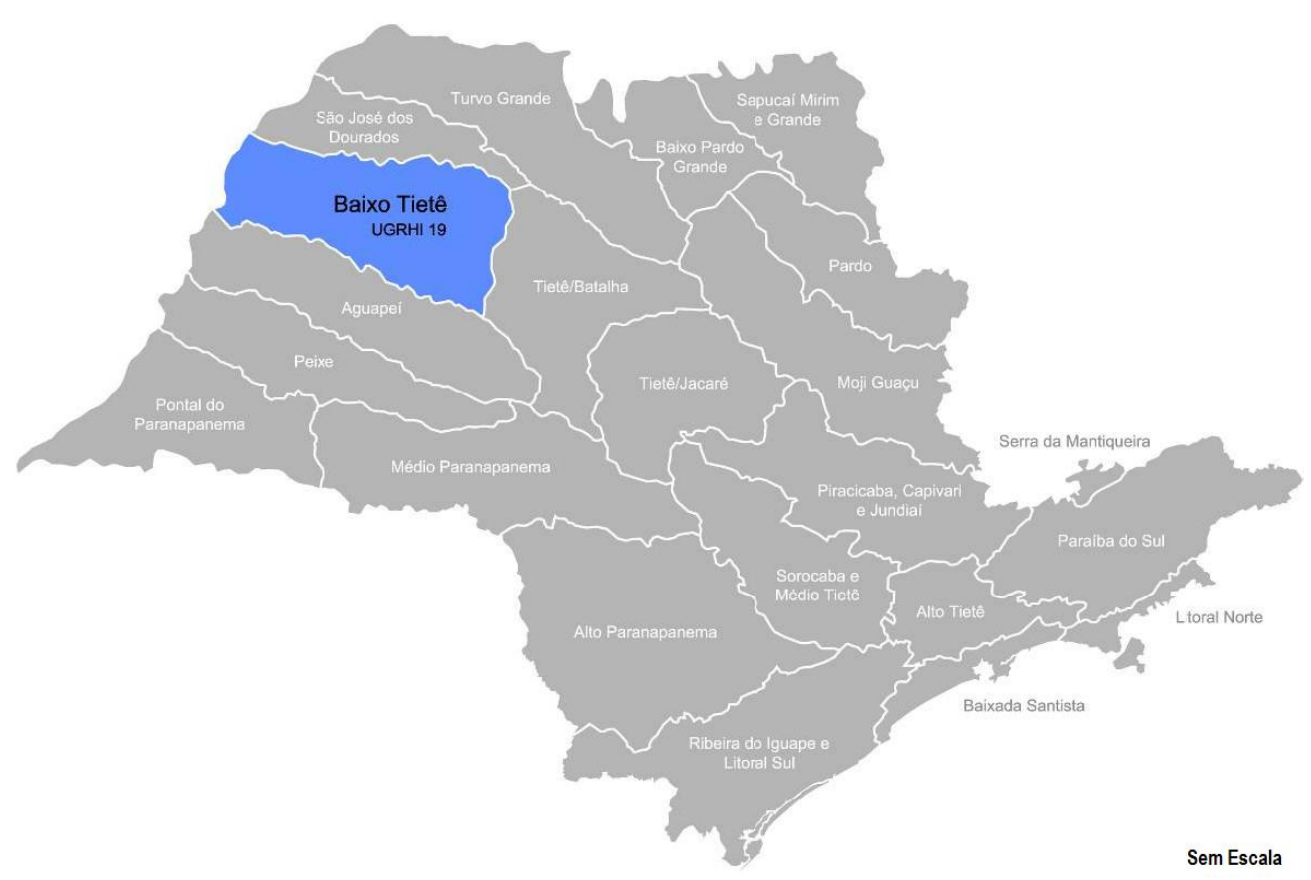

Figura 6. Divisão hidrográfica do Estado de São Paulo. Em destaque a Unidade de Gerenciamento de Recursos Hídricos n. 19 - Bacia Hidrográfica do Baixo Tietê.

Fonte: (CETEC, 2008).

Grande parte das informações utilizadas neste trabalho para descrever as características da região basearam-se no documento norteador das ações relacionadas aos recursos hídricos no Estado de São Paulo, o "Relatório de Situação de Recursos Hídricos", ou também conhecido como "Relatório Zero" (CETEC, 2001), que depois de várias reuniões culminou no "Relatório Final do Plano de Bacia do Baixo Tietê" (CETEC, 2008).

Conforme pode ser observado na Figura 6, a Bacia Hidrográfica do Baixo Tietê limita-se ao Norte com a Bacia Hidrográfica do Rio São José dos Dourados (UGRHI n. ${ }^{\circ} 18$ ), ao sul com a Bacia Hidrográfica do Rio Aguapeí (UGRHI n. ${ }^{\circ}$ 20), a leste com a Bacia Hidrográfica do Tietê/Batalha (UGRHI n. ${ }^{\circ}$ 16) e a oeste com o Estado de Mato Grosso do Sul.

A Bacia do Baixo Tietê estende-se, através do curso natural do Rio Tietê, desde o reservatório da UHE de Promissão até a confluência com o Rio Paraná, já na divisa com o Estado de Mato Grosso do Sul, tendo este percurso, aproximadamente, $221 \mathrm{~km}$.

Possui uma área de drenagem de aproximadamente $15.500 \mathrm{~km}^{2}$, na qual estão inserida as UHE de Três Irmãos e Nova Avanhandava. Tendo os principais cursos de água: o Rio Paraná e seu afluente, Ribeirão do Abrigo; Rio Tietê e seus afluentes, Ribeirão Lajeado, Ribeirão do Aracanguá, Ribeirão Macaúbas e Ribeirão Santa Barbára (CETEC, 2008). 
A seguir, serão detalhados aspectos físicos da Bacia Hidrográfica do Baixo Tietê.

\section{$\checkmark$ Geologia}

A região situa-se na Bacia Sedimentar do Paraná, formada por rochas sedimentares e vulcânicas, podendo ser encontrados depósitos coluvionares e aluvionares (CETEC, 2008).

Na Bacia do Baixo Tietê, a Formação Serra Geral aflora ao longo de vales do Rio Tietê e também na confluência com seus principais afluentes, nas várzeas e entorno do Rio Paraná a partir de Jupiá, à montante, até a divisa da bacia. Nestas áreas, os basaltos podem ser identificados pela presença de solos vermelho-escuros e argilosos.

Os sedimentos do Grupo Bauru são subdivididos em duas formações: Santo Anastácio e Adamantina, ambas sobre a Formação Serra Geral. As rochas destes grupos foram originadas em um ambiente de sedimentação continental flúvio-lacustre, conferindo grande descontinuidade.

A Formação Santo Anastácio tende a ter sua espessura reduzida no sentido leste, a partir do Rio Paraná, de forma que suas cotas mais baixas são encontradas ao longo do Rio Tietê e seus afluentes, sendo a área de maior exposição no extremo oeste.

A Formação Adamantina é de ampla distribuição, sendo encontrada nos níveis mais elevados do terreno por ter sido removida pelos processos erosivos nos vales dos rios (CETEC, 2008).

\section{$\checkmark$ Recursos minerais}

Compostos por matérias primas para a construção civil (argila, areia, cascalho e brita), encontradas nas planícies aluviais dos corpos de água, atualmente submersas pelos reservatórios das barragens, entretanto existem áreas propensas para a exploração de argilas em áreas não inundadas (CETEC, 2008).

\section{$\checkmark$ Geomorfologia}

Situa-se na Província Geomorfológica do Planalto Ocidental, cuja característica é a presença de formas de relevo levemente onduladas com longas encostas e baixa declividade. Os pontos mais altos da Bacia podem alcançar mais de $560 \mathrm{~m}$ e próximo a Ilha Comprida, na foz do Córrego do Moinho, 264 m (CETEC, 2008). 


\section{$\checkmark$ Pedologia}

As variedades de tipos de solo estão relacionadas à pequenas ocorrências de basaltos da formação Serra Geral que afloram nos vales dos principais cursos d'água (trecho do Rio Paraná e seus afluentes, além do Tietê, próximo à desembocadura). Sendo os principais segundo CETEC (2008):

- Solos com Horizonte B Textural: horizonte mineral subsuperficial que possui incremento de argila, bem drenados e sem influência de salinização;

- Solos podzolizados de Lins e Marília - variedade Lins: solos com profundidades variáveis entre 2 e 3 metros, bem drenados, arenosos, encontrados em relevos ondulados;

- Solos podzolizados de Lins e Marília - variedade Marília: solos pouco mais rasos do que a variedade Lins com a mesma seqüência de horizontes;

- Solos com Horizonte B Latossólico: horizonte mineral subsuperficial em estágio avançado de intemperismo.

\section{$\checkmark$ Potencial agrícola}

É considerada como uma das últimas fronteiras de expansão agropecuária do Estado de São Paulo, sendo a pecuária de corte e a cana-de-açúcar as atividades mais importantes. O café e o algodão perderam foco dos produtores nos últimos anos, mas foram bastante influentes na degradação dos solos da região. No geral, existem pequenas áreas com terras férteis para cultivo de ciclo curto. As maiores limitações devem-se à fertilidade e a suscetibilidade à erosão, além de que grande parte dos solos encontram-se em estágio avançado de degradação (CETEC, 2008).

\section{$\checkmark$ Hidrometeorologia}

A região é influenciada pelas massas de ar Tropical Continental (seca e quente) e Polar Antártica (fria e úmida). O regime pluviométrico caracteriza-se com um período chuvoso de outubro a abril, e um período de seca (estiagem) de maio a setembro. O acumulado anual é da ordem de 1000 a $1300 \mathrm{~mm}$. O clima é caracteristicamente tropical, com inverno úmido e com a temperatura em queda, sendo o mês de julho o mais frio (temperaturas entre 14 e $22^{\circ} \mathrm{C}$ ). $\mathrm{O}$ verão é caracterizado por temperaturas altas (entre 24 e $30^{\circ} \mathrm{C}$ ), úmido e com chuvas fortes (CETEC, 2001). 


\section{$\checkmark$ Biodiversidade}

Constituída por remanescentes de Mata Atlântica, capoeiras e cerrado. Localiza-se na Bacia uma reserva biológica, alguns parques ecológicos e viveiros de mudas. Animais como o sauá, o veado-catingueiro, o macaco-prego, o bugio, o tamanduá-mirim, a seriema, a maritaca e o tucano-azul, podem ser encontrados na área da Bacia. Foram catalogadas 22 famílias e 166 espécies de peixes, destacando-se os curimbatás, piaparas, pintados e jaús (CASTRO e MENEZES, 1998).

\section{$\checkmark$ Uso e ocupação do solo}

Os levantamentos iniciais, utilizados para detalhamento da situação dos recursos hídricos, concluíram a análise do uso e ocupação do solo da bacia em 8 categorias, sendo necessárias as seguintes considerações:

- Cobertura vegetal remanescente são os vários tipos fisionômicos de vegetação como mata, capoeira, campo, cerradão, cerrado, campo cerrado e vegetação de várzea;

- Reflorestamento são formações florestais artificiais, disciplinadas e homogêneas nas quais predominam o plantio de pinus e eucaliptos;

- Culturas perenes são representadas na área de estudo por café, citrus, seringueira, amora e outras frutíferas;

- Predomínio de culturas temporárias são representadas na área de estudo pelas culturas de algodão, amendoim, arroz, feijão, milho, mandioca, soja e trigo;

- Cultura semi-perene é representada pela cultura de cana-de-açúcar que se concentra nos municípios de Araçatuba, Santo Antônio de Aracanguá, Penápolis, Avanhandava, Gurarapes e Vicentópolis;

- E, pastagens: é a classe de uso predominante na região variando desde áreas organizadas para a pecuária, apresentando pastos com diversas fases de crescimento, indicando um rodízio no uso, e áreas abandonadas, sem qualquer tratamento.

Desta forma as classes de uso e ocupação do solo foram tabeladas segundo suas áreas e seus respectivos percentuais em relação à área da URGHI, cujos valores são apresentados na Tabela 4. 
Tabela 4. Uso e ocupação do solo da Bacia do Baixo Tietê.

\begin{tabular}{lcc}
\hline Classes de uso do solo & Área $\left[\mathbf{K m}^{2}\right]$ & $\begin{array}{c}\text { Percentual em relação à } \\
\text { área da UGRHI 19 }\end{array}$ \\
\hline Cobertura vegetal natural & 394,92 & 2,36 \\
$\begin{array}{l}\text { Reflorestamento } \\
\text { Predomínio de culturas }\end{array}$ & 17,37 & 0,10 \\
perenes/semi-perenes & $1.234,06$ & 7,39 \\
$\begin{array}{l}\text { Predomínio de culturas temporárias } \\
\text { Cultura semi-perene (cana-de-açúcar) }\end{array}$ & 978,72 & 5,86 \\
$\begin{array}{l}\text { Pastagens } \\
\text { Áreas urbanas e sistema rodo- }\end{array}$ & $1.085,24$ & 6,50 \\
ferroviário & 65,45 & 77,39 \\
\hline
\end{tabular}

Fonte: (CETEC, 2008).

\section{$\checkmark$ Áreas assoreadas}

$\mathrm{Na}$ UGRHI 19 os reservatórios para fins de geração de energia elétrica ali implantados são relativamente jovens. As obras de construção da UHE de Nova Avanhandava e da UHE de Três Irmãos, ambas no Rio Tietê, foram finalizadas, respectivamente, em 1982 e 1990.

Por isto, são raros os trabalhos sobre os processos erosivos nesta região. Entretanto, segundo CETEC (2008) alguns trabalhos do IPT concluíram que voçorocas próximas aos reservatórios são responsáveis por seu assoreamento.

\subsubsection{A sub-bacia do Ribeirão das Cruzes}

Também para fins de gerenciamento de recursos hídricos, a UGRHI 19 foi subdivida em sub-bacias, segundo o método desenvolvido pelo Engenheiro Otto Pfafstetter, dando origem à delimitação da sub-bacia do Ribeirão das Cruzes (Figura 7), ao sul inserida no município de Santo Antônio do Aracanguá e ao norte no município de Auriflama. 


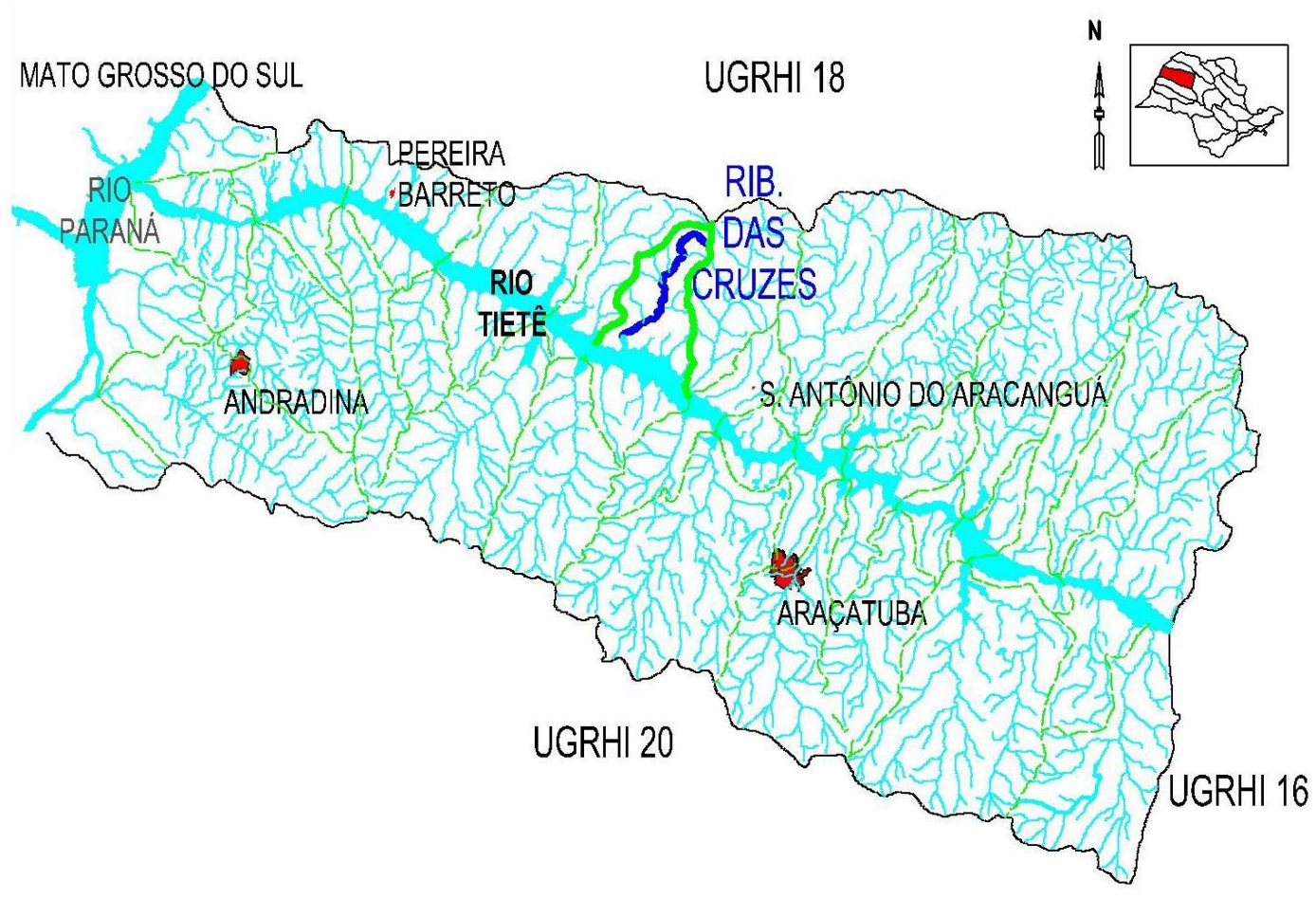

(a)

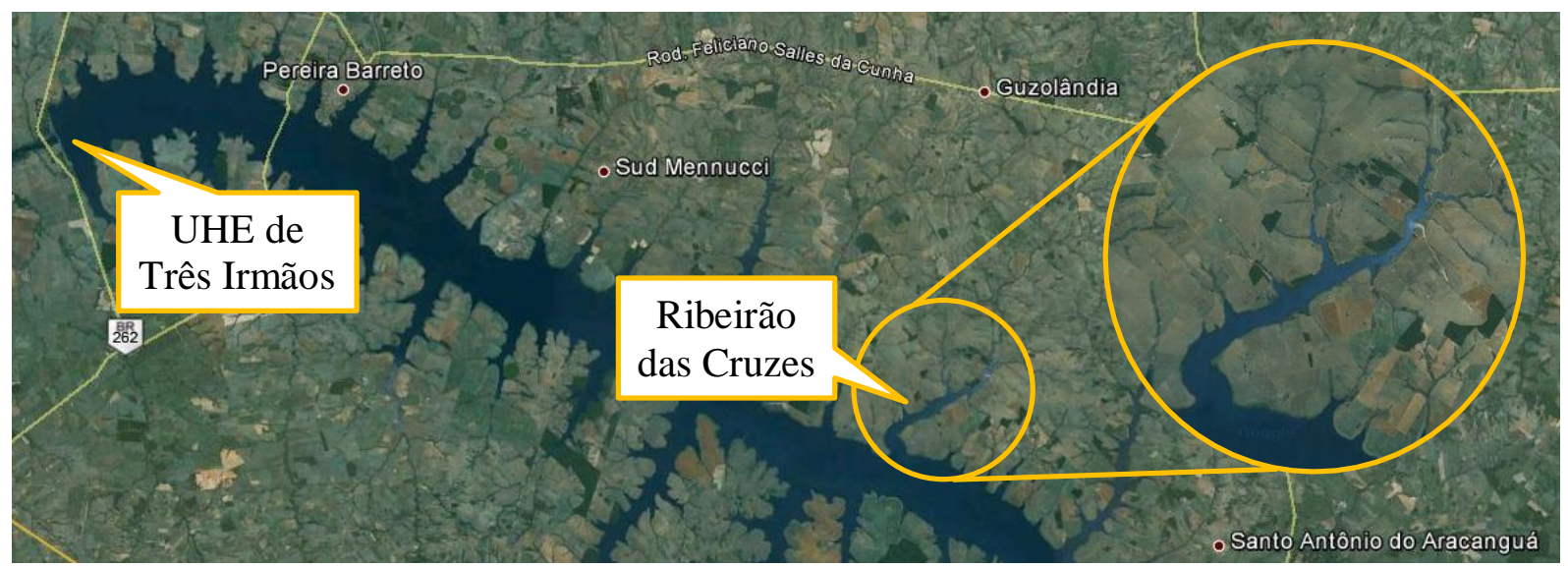

(b)

Figura 7. Localização da sub-bacia do Ribeirão das Cruzes.

(a) Delimitação da sub-bacia segundo CETEC (2001). (b) Imagem de satélite da área, com destaque para a sub-bacia do Ribeirão das Cruzes e a UHE de Três Irmãos.

A sub-bacia do Ribeirão das Cruzes situa-se na margem direita do reservatório da UHE de Três Irmãos, no município de Santo Antônio do Aracanguá, com aproximadamente 207,68 km² de área de drenagem. 


\subsection{Detalhamento da metodologia}

\subsubsection{Compartimentação da bacia e campanhas de campo}

Com o intuito de melhor entender os processos ambientais que ocorrem na subbacia do Ribeirão das Cruzes, cujo comportamento do ambiente aquático deve ser considerado como lêntico, devido ao barramento provocado pela construção da UHE de Três Irmãos, e gerar informações para subsidiar o manejo adequado do solo e da bacia hidrográfica como um todo, a área de estudo foi subdividida em transectos segundo as principais características do uso e ocupação do solo no entorno da área da sub-bacia do Ribeirão das Cruzes.

Neste trabalho foram feitas duas campanhas de campo: a primeira, entre os dias 10 e 14 de janeiro de 2011, considerada como a campanha relativa à Estação Chuvosa; e a segunda, entre os dias 30 de agosto e 2 de setembro de 2011, considerada como a campanha relativa à Estação Seca.

Na Figura 8 está representada a carta de uso e ocupação do solo da sub-bacia do Ribeirão das Cruzes bem como estão representados os 7 (sete) Transectos de amostragem utilizados neste trabalho. Na Figura 9 estão representadas algumas fotos das áreas no entorno desses transectos.

Para fins de quantificação das taxas de exportação, ou seja, para quantificação da descarga sólida destes Transectos, foi estabelecido o número de verticais de amostragens baseando-se nos estudos realizados pela CEMIG (1965), que devido a questões práticas e econômicas, foi fixado em 3 (três) verticais, dispostas à 1/4, 1/2 e 3/4 da largura do transecto.

Assim, cada transecto teve então 3 pontos de amostragem, relativos à margem direita, ao centro e à margem esquerda dos transectos. Os cálculos realizados consideram a média dos valores dos 3 pontos de coleta.

$\mathrm{Na}$ Tabela 5 estão dispostas as coordenadas UTM de cada ponto de coleta e o erro absoluto de posicionamento entre cada ponto, calculado como sendo à distância linear do ponto entre as Estações Chuvosa e Seca. Na Figura 10, para melhor visualização da dispersão dos pontos de coleta de dados entre Estações, os mesmos foram especializados segundo suas coordenadas geográficas. 
Carta de Uso e Ocupação do Solo da Sub-Bacia Hidrográfica do Ribeirão das Cruzes e Localização dos Transectos de Amostragem

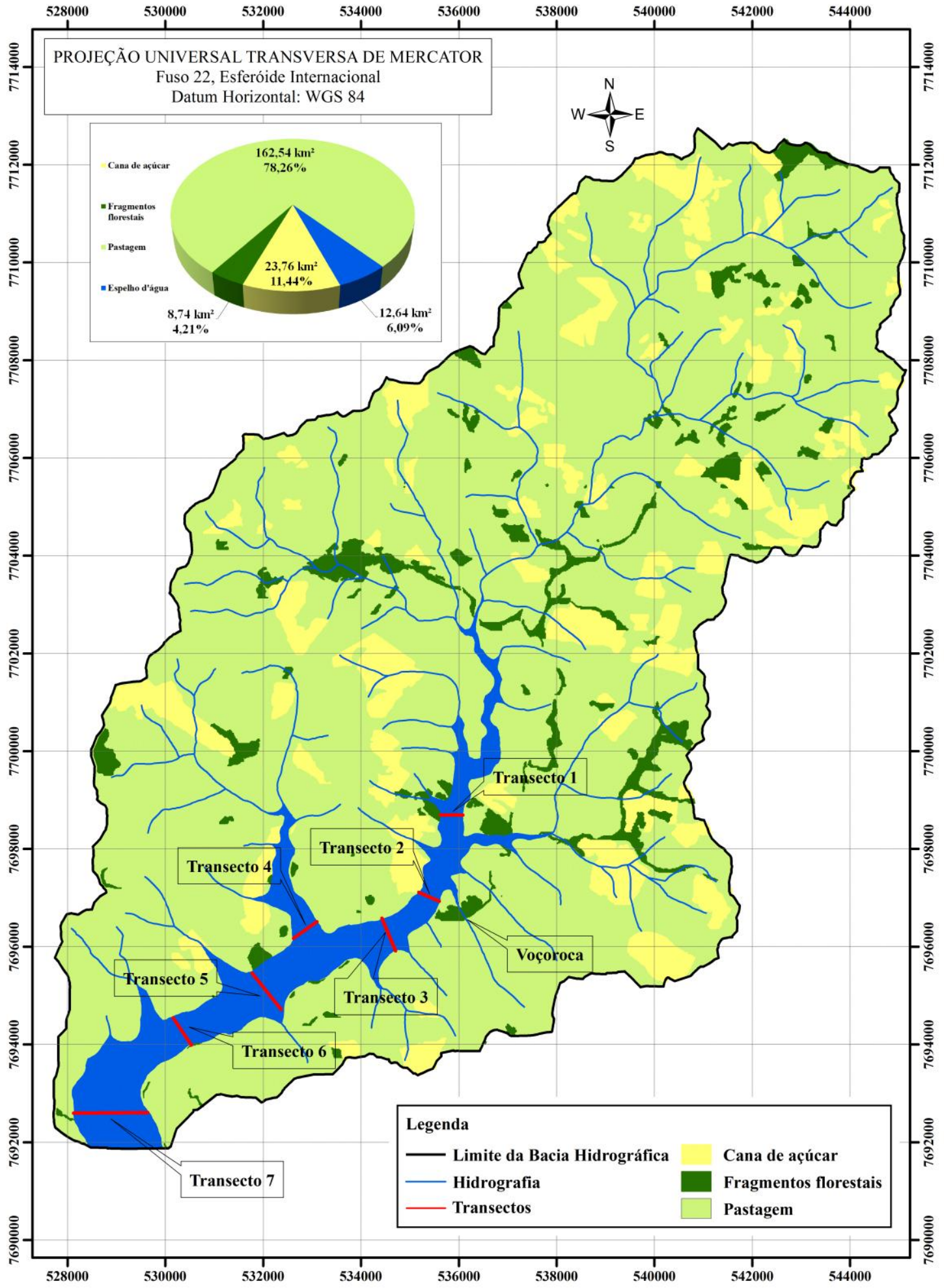

Figura 8. Carta de uso e ocupação do solo da sub-bacia do Ribeirão das Cruzes e localização dos Transectos de amostragem. 


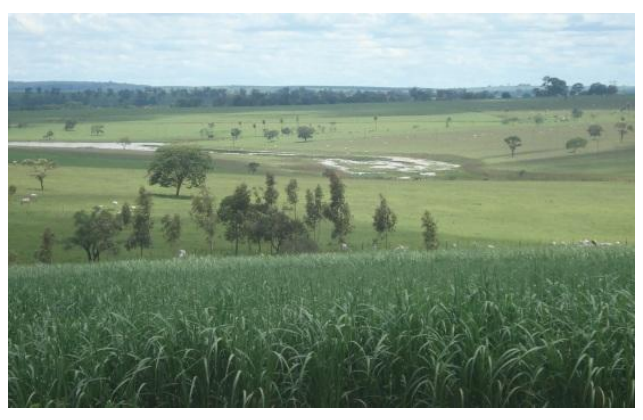

(a)

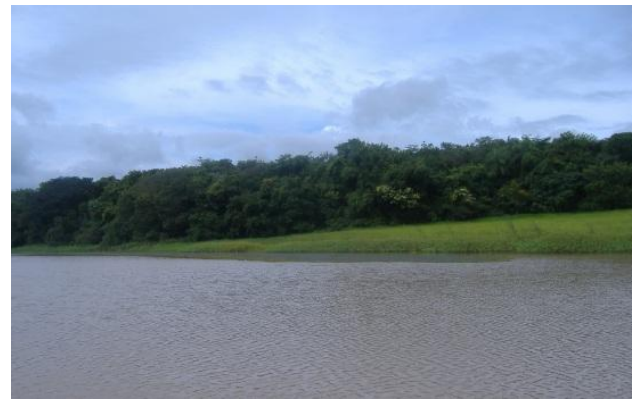

(c)

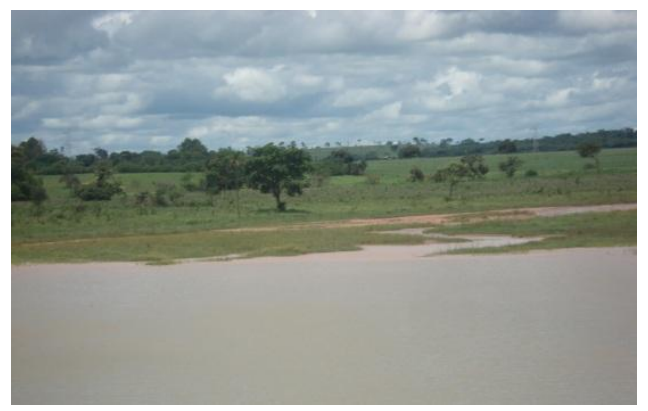

(e)

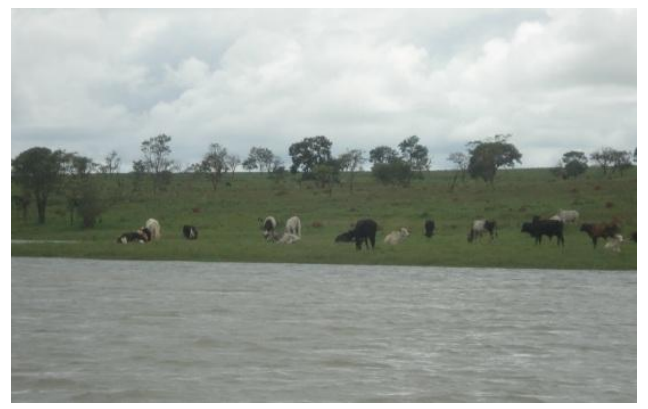

(g)

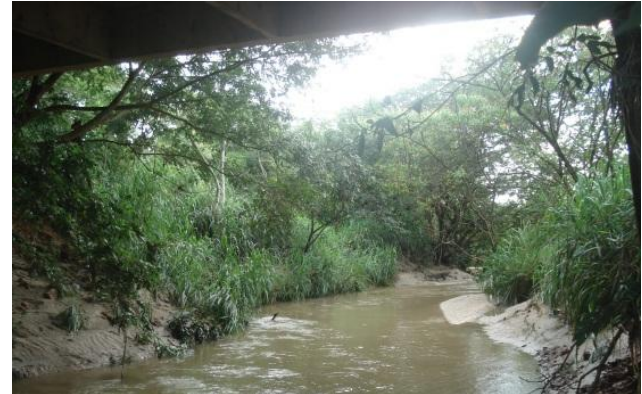

(b)

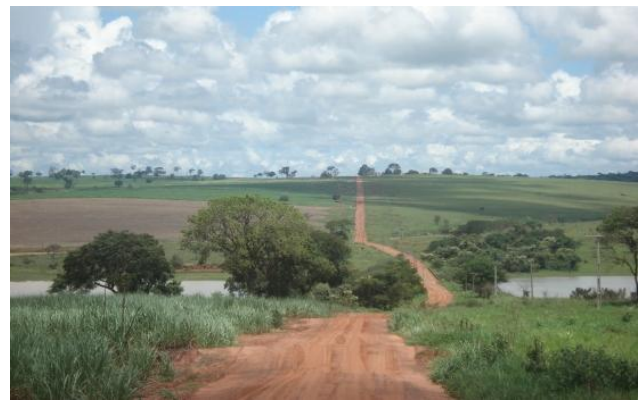

(d)

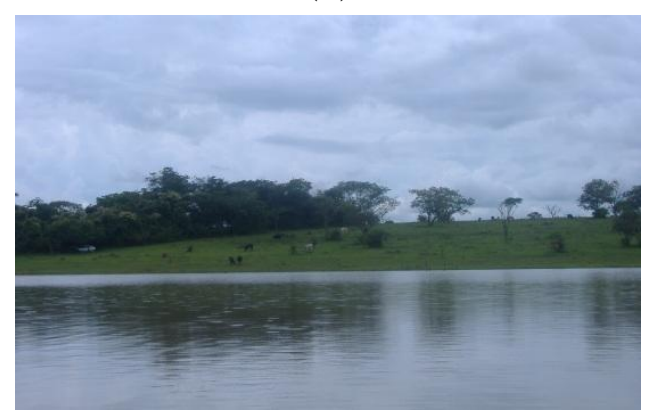

(f)

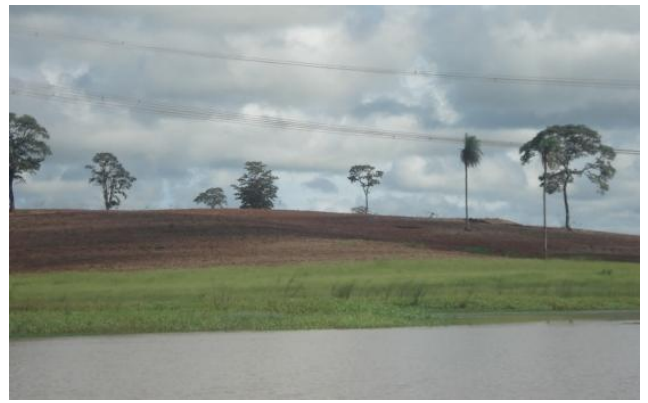

(h)

Figura 9. Fotos das áreas no entorno dos Transectos.

(a) Vista geral das áreas do entorno das nascentes do Ribeirão das Cruzes. (b) Ponte sobre o Ribeirão das Cruzes, à montante do Transecto 1. (c) Remanescente florestal na margem direita do Transecto 1. (d) Vista geral do entorno à montante do Transecto 2. (e) Grande área assoreada na margem esquerda à montante do Transecto 2, cujo sedimentos são provenientes da voçoroca ilustrada na Figura 4. (f) Pastagens na margem esquerda do Transecto 3. (g) Pastagens na margem direita do Transecto 5. (h) Área com solo nu, preparado para plantio de cana de açúcar na margem direita à montante do Transecto 6. 
Tabela 5. Coordenadas UTM dos pontos de coleta nas Estações Chuvosa e Seca.

\begin{tabular}{|c|c|c|c|c|c|c|}
\hline \multirow{3}{*}{ 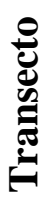 } & \multirow{3}{*}{ Ponto } & \multicolumn{4}{|c|}{ Campanha } & \multirow{3}{*}{$\begin{array}{c}\text { Erro absoluto de } \\
\text { posicionamento } \\
\text { (m) }\end{array}$} \\
\hline & & \multicolumn{2}{|c|}{ Estação Chuvosa } & \multicolumn{2}{|c|}{ Estação Seca } & \\
\hline & & UTM X (m) & UTM Y (m) & UTM X (m) & UTM Y (m) & \\
\hline \multirow{3}{*}{1} & MD & 535.787 & 7.698 .675 & 535.781 & 7.698 .636 & 39 \\
\hline & $\mathrm{C}$ & 535.809 & 7.698 .674 & $535.805^{*}$ & $7.698 .637 *$ & 37 \\
\hline & $\mathrm{ME}$ & 535.849 & 7.698 .654 & 535.847 & 7.698 .639 & 15 \\
\hline \multirow{3}{*}{2} & MD & 535.342 & 7.697 .005 & 535.358 & 7.697.012 & 17 \\
\hline & $\mathrm{C}$ & 535.385 & 7.696 .985 & 535.403 & 7.696 .980 & 19 \\
\hline & $\mathrm{ME}$ & 535.441 & 7.696 .952 & 535.456 & 7.696 .953 & 15 \\
\hline \multirow{3}{*}{3} & MD & 534.403 & 7.696.348 & 534.421 & 7.696 .337 & 21 \\
\hline & $\mathrm{C}$ & 534.434 & 7.696.289 & 534.481 & 7.696 .256 & 57 \\
\hline & ME & 534.496 & 7.696 .183 & 534.524 & 7.696 .189 & 29 \\
\hline \multirow{3}{*}{4} & MD & 532.822 & 7.696 .247 & 532.816 & 7.696 .251 & 7 \\
\hline & $\mathrm{C}$ & 532.860 & 7.696.241 & 532.884 & 7.696.277 & 43 \\
\hline & $\mathrm{ME}$ & 532.956 & 7.696.266 & 532.969 & 7.696.265 & 13 \\
\hline \multirow{3}{*}{5} & $\mathrm{MD}$ & 531.828 & 7.695.224 & 531.885 & 7.695.278 & 79 \\
\hline & $\mathrm{C}$ & 531.920 & 7.695 .055 & 531.887 & 7.695 .051 & 33 \\
\hline & $\mathrm{ME}$ & 532.050 & 7.694 .855 & 532.041 & 7.694.858 & 9 \\
\hline \multirow{3}{*}{6} & MD & 530.873 & 7.694 .745 & 530.914 & 7.694.749 & 41 \\
\hline & $\mathrm{C}$ & $530.978 *$ & $7.694 .591 *$ & 531.025 & 7.694.598 & 48 \\
\hline & $\mathrm{ME}$ & $531.116 *$ & $7.694 .413^{*}$ & 531.110 & 7.694.408 & 8 \\
\hline \multirow{3}{*}{7} & MD & $529.509 *$ & $7.694 .069 *$ & 529.508 & 7.694 .045 & 24 \\
\hline & $\mathrm{C}$ & 529.594 & 7.693 .936 & 529.578 & 7.693 .879 & 59 \\
\hline & $\mathrm{ME}$ & $529.700 *$ & $7.693 .725^{*}$ & 529.657 & 7.693.749 & 49 \\
\hline
\end{tabular}

MD - Margem Direita; C - Centro; ME - Margem Esquerda.

* Apesar de devidamente posicionados, inclusive com a marcação das suas coordenadas de localização, as armadilhas destes pontos de amostragem foram perdidas. 


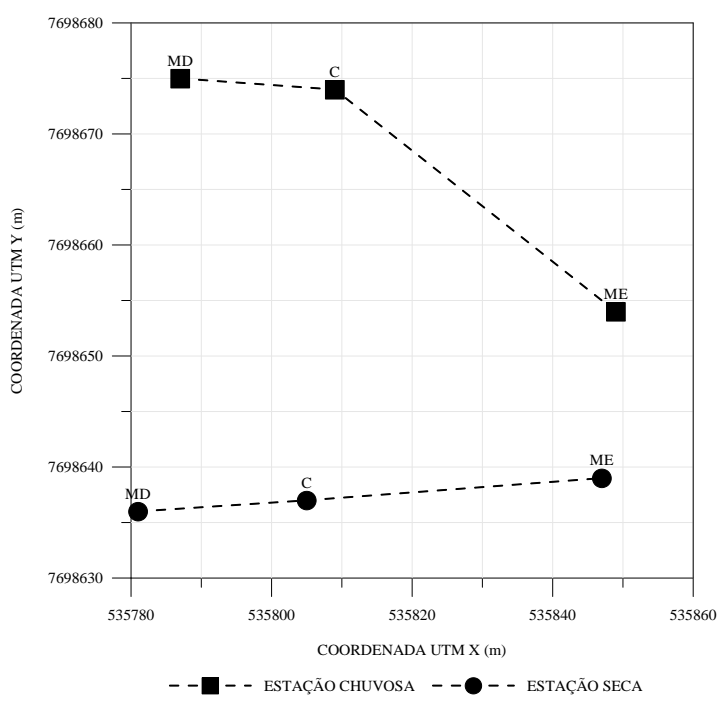

(a) Transecto 1.

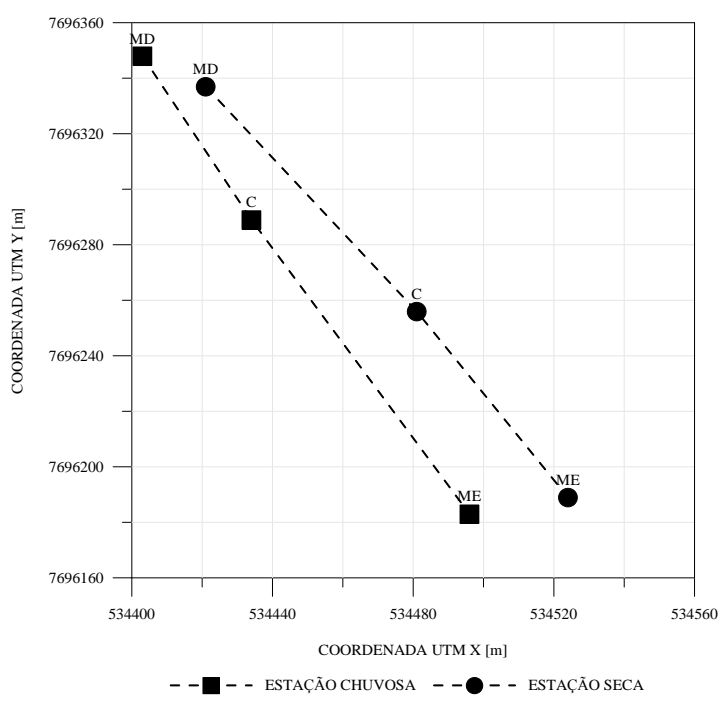

(c) Transecto 3.

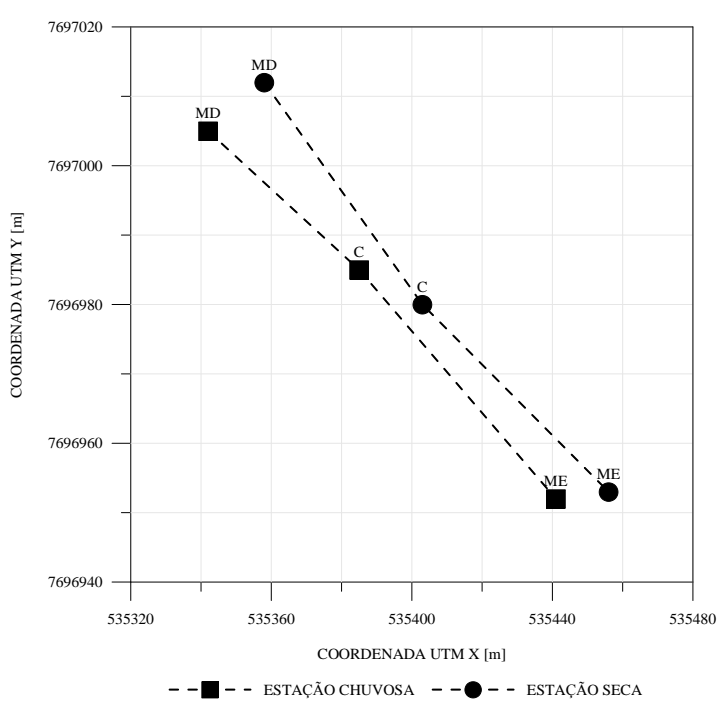

(b) Transecto 2 .

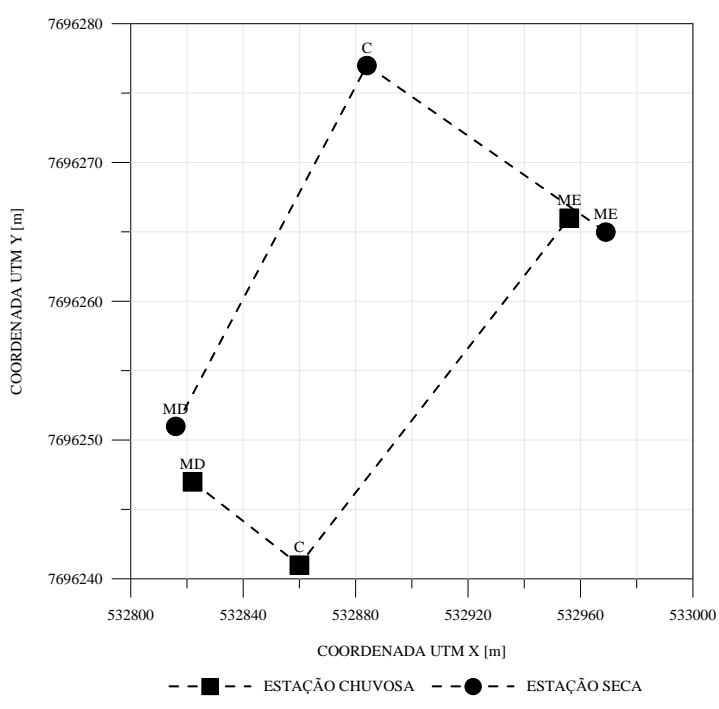

(d) Transecto 4.

Figura 10. Dispersão entre os pontos de coleta nos Transectos. 


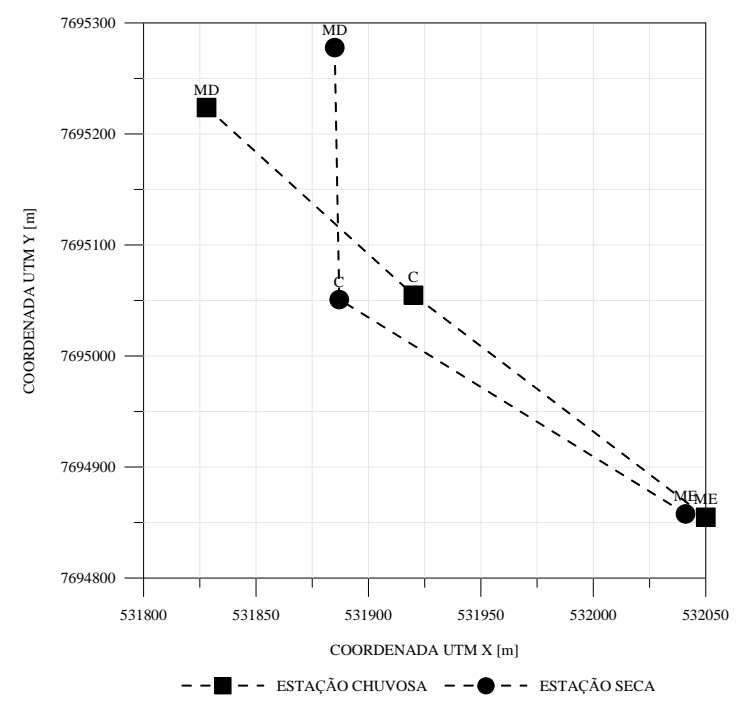

(e) Transecto 5.

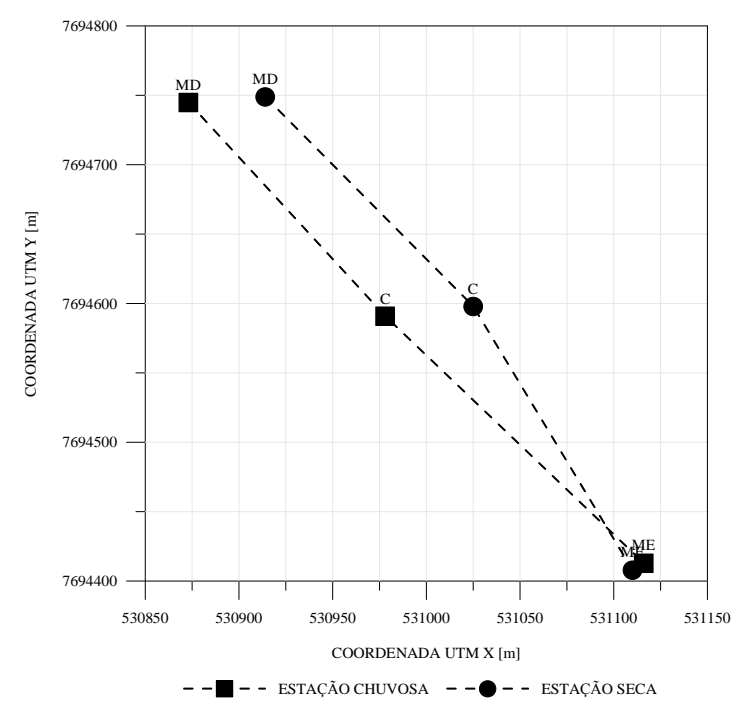

(f) Transecto 6.

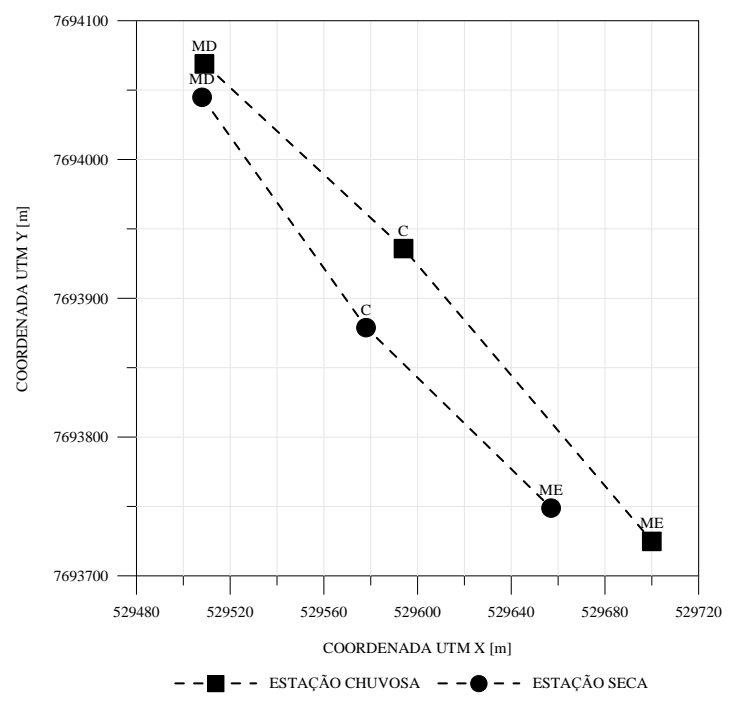

(g) Transecto 7.

Figura 10. (Continuação) Dispersão entre os pontos de coleta nos Transectos.

Os Transectos compartimentam a sub-bacia de modo que cada um dos Transectos à jusante recebem a contribuição das cargas de sólidos e nutrientes dos Transectos à montante, além da contribuição específica de suas bacias de contribuição. Por exemplo, o Transecto 3, que recebe a contribuição das cargas dos Transectos 2 e 1 e de toda a sua bacia de contribuição.

Nesta sistemática, apenas o Transecto 4 não é influenciado diretamente pelos Transectos à montante, ou seja, os Transectos 3, 2 e 1, pois o Transecto 4 recebe suas cargas de uma bacia de contribuição específica, isto é, de um afluente do Ribeirão das Cruzes, o Córrego do Barreiro. 
Neste sentido, segundo a disposição geográfica dos Transectos, como representado pela Figura 8, pode-se considerar que o Transecto 1 recebe as cargas da bacia de contribuição onde se localizam as nascentes da área de estudo.

Noutra ponta, o Transecto 7 acumula todas as cargas dos demais transectos, e o mais importante, pode ser utilizado para cálculo final da exportação de sólidos e nutrientes para o Reservatório de Três Irmãos.

Na primeira campanha, ou seja, na Estação Chuvosa, os pontos de coleta em cada Transecto, isto é, os locais de amostragem localizados na margem direita, ao centro e na margem esquerda foram georreferenciados, visando melhor precisão para retirada das câmaras após período de incubação e principalmente para revisita ao ponto na próxima campanha.

Porém, deve-se considerar certa dificuldade de alocação de cada ponto de coleta na segunda campanha em relação à sua localização na primeira campanha, pois incide o erro devido ao posicionamento do GPS e principalmente a dificuldade operacional em se posicionar o barco exatamente sobre o mesmo local, quando para isto é necessário considerar a direção do vento, a interferência provoca pelas ondas de outras embarcações, dentre outros fatores.

Entretanto, para os objetivos propostos nesta dissertação, considerando a escala de trabalho, não é relevante o erro provocado pelo posicionamento dos pontos de coleta entre as campanhas.

Vale ressaltar alguns contratempos ocorridos nos experimentos. Durante a realização dos experimentos da Estação Chuvosa, foram perdidas as armadilhas do centro e margem esquerda do Transecto 6 e das margens direita e esquerda do Transecto 7. Nos experimentos da Estação Seca, apenas a armadilha do centro do Transecto 1 foi perdida.

Estas perdas podem estar relacionadas a diversos fatores: i) rompimento da corda que une o lastro, a armadilha, propriamente dita, e a boia de localização superficial; ii) arraste provocado por embarcações; iii) interferência de terceiros.

Mesmo com a perda dessas informações, aqueles Transectos afetados não foram desconsiderados nas análises realizadas, pois não consideramos ser impeditiva a análise conjunta dos aspectos ambientais envolvidos. 
4.2.2. Coleta de dados de qualidade in situ

Utilizando-se uma sonda multiparâmetros, modelo YSI 6820 (Figura 11) foram coletados dados relativos à qualidade da água, em cada perfil vertical dos pontos de coleta no momento em que estavam sendo instaladas as armadilhas de sedimentação. Estes dados referem-se à: concentração de oxigênio dissolvido $\left(\mathrm{mg} \mathrm{L}^{-1}\right)$; $\mathrm{pH}$; e, temperatura $\left({ }^{\circ} \mathrm{C}\right)$.
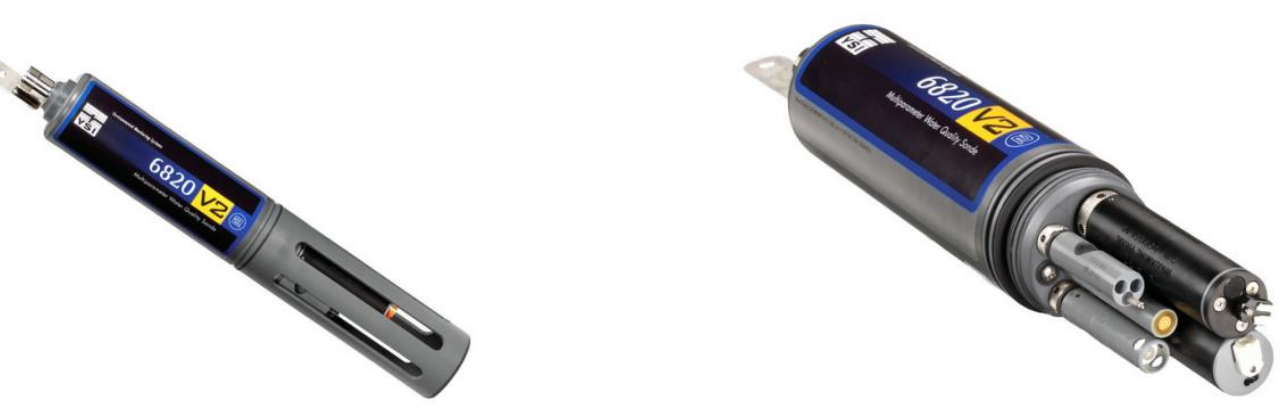

Figura 11. Sonda multiparâmetros modelo YSI 6820, utilizada nos trabalhos de campo. Fonte: (YSI, 2012).

A sistemática adotada para leitura dos parâmetros foi a seguinte: foram coletados dados a cada $0,2 \mathrm{~m}$, entre a superfície e 1,0 $\mathrm{m}$ de profundidade; em sequência foram coletados dados a cada $0,5 \mathrm{~m}$, até $5,0 \mathrm{~m}$ de profundidade; e por final, foram coletados dados a cada 1,0 $\mathrm{m}$ até o fundo do perfil em análise, atentando-se para a estabilidade dos dados apresentados pelo sensor da sonda.

4.2.3. Deposição de sólidos e nutrientes

Para estudo da deposição de sólidos e nutrientes foram fabricadas armadilhas de sedimentação, utilizando tubos de PVC com $10 \mathrm{~cm}$ de diâmetro e $50 \mathrm{~cm}$ de comprimento, sendo cada armadilha composta um conjunto de 4 tubos, conforme representado na Figura 12, a seguir. 


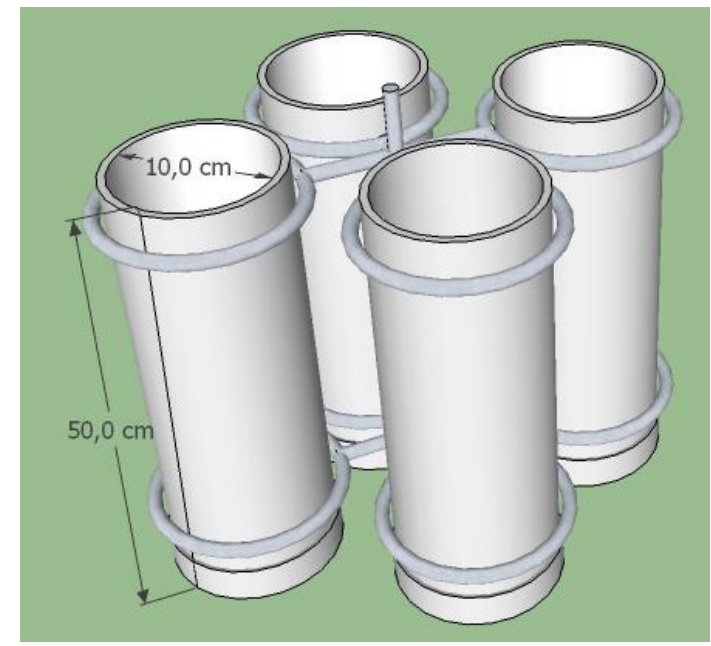

(a)

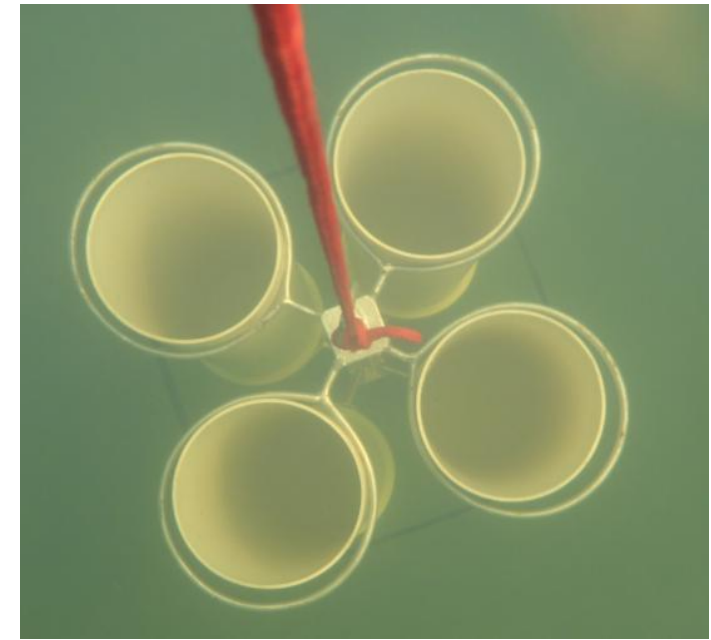

(b)

Figura 12. Armadilhas de sedimentação, utilizadas nos trabalhos de campo.

(a) dimensionamento construtivo da armadilha.

(b) imagem subaquática da armadilha sendo utilizada em campo.

Estas armadilhas foram dispostas verticalmente na coluna d'água, o que denominamos incubação. Antes do processo de incubação as armadilhas tiveram seu conteúdo preenchido com água da superfície do ponto de coleta, sendo que 3 alíquotas de $500 \mathrm{~mL}$ dessa água superficial foram coletadas e levadas à laboratório para análise de sólidos suspensos (orgânicos e inorgânicos), nitrito, nitrato, nitrogênio amoniacal, nitrogênio total Kjeldahl, fosfato total dissolvido, ortofosfato, fósforo total e silicatos reativos, conforme metodologias descritas na Tabela 6.

As armadilhas foram então posicionadas em profundidades específicas na coluna d'água, na interface entre o limite da zona eufótica e afótica de cada ponto de coleta.

Estas armadilhas foram ancoradas com lastros e amarradas com boias, parcialmente submersas, evitando-se possíveis perdas do equipamento por arraste devido às ondas e ao vento, preservando e facilitando sua localização para retirada após decorrido o período de incubação.

O período de incubação foi de 24 horas, conforme experimentos semelhantes realizados por Leite (1998). É de conhecimento que Edmondson e Winberg (1972) sugeriram um período de incubação de 15 a 30 dias e Maricato (1994) sugeriu um período de incubação de 7 a 11 dias. No entanto, além de ter sido considerado satisfatório os experimentos realizados por Leite (1998) utilizando o mesmo período de incubação, deve-se atentar para o iminente risco de perda de equipamento quando da exposição prolongada.

Passado o período de incubação, as armadilhas foram retiradas cuidadosamente e 
o conteúdo foi homogeneizado em galão de 20 litros. Do conteúdo homogeneizado foram coletadas novas 3 alíquotas, de $500 \mathrm{~mL}$ cada, que foram levadas à laboratório para análise de sólidos suspensos, nitrito, nitrato, nitrogênio amoniacal, nitrogênio total Kjeldahl, fosfato total dissolvido, ortofosfato, fósforo total e silicatos reativos conforme esquema representado na Figura 13, segundo as metodologias descritas na Tabela 6.

Das três alíquotas armazenadas, utilizou-se uma para análise de nutrientes dissolvidos e outra para análise de nutrientes totais, desta forma, sempre uma alíquota foi mantida de reserva para fins de reanálise.

As análises de sólidos suspensos, nitrito, nitrato, fosfato total dissolvido, ortofosfato, e fósforo total e silicatos reativos foram realizadas em duplicata.

Assim, foi possível avaliar a diferença espacial dos processos de sedimentação que ocorrem na sub-bacia, bem como a forma de expressão destes por compartimentos e, ainda, calcular a quantidade de partículas sólidas (sedimentos) e nutrientes que se depositam ao longo de um ciclo diário.

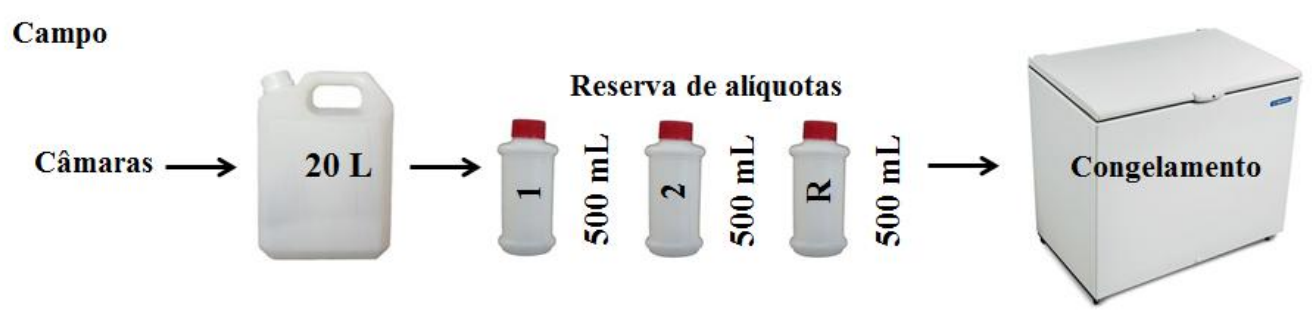

Laboratório
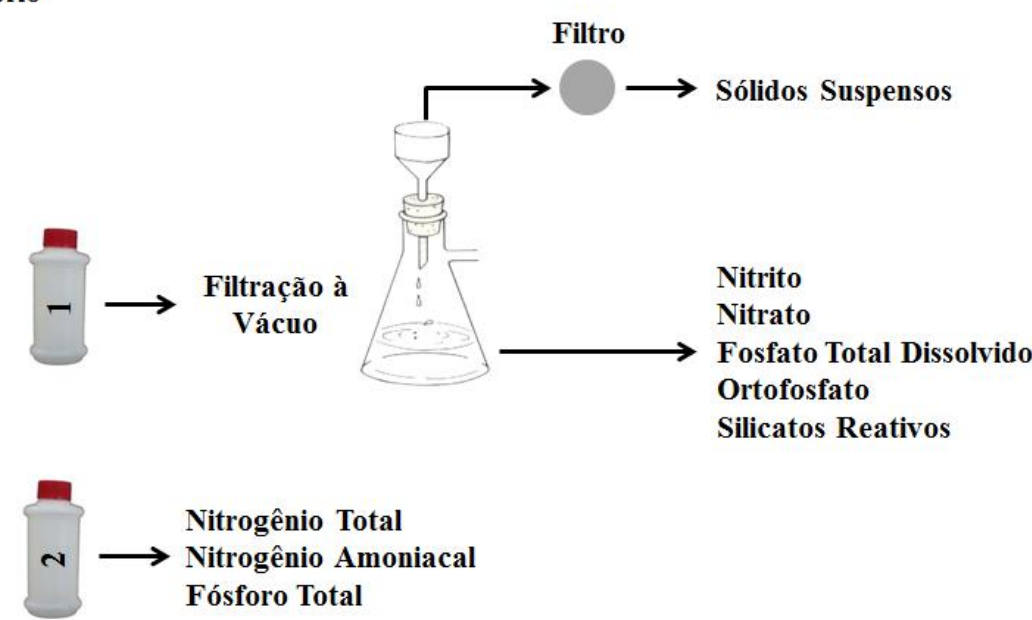

Figura 13. Esquema de tratamento e análise das amostras coletadas. 
Tabela 6. Amostras de água - técnicas e referências metodológicas.

\begin{tabular}{|c|c|c|}
\hline Análise & Técnica & Referência \\
\hline Sólidos Suspensos & Gravimetria & $\begin{array}{l}\text { APHA (2002) - Método 2540D e } \\
\text { 2540E }\end{array}$ \\
\hline Nitrito & Espectrofotometria & APHA (2002) - Método 4500B \\
\hline Nitrato & Espectrofotometria & APHA (2002) - Método 4500D \\
\hline Nitrogênio amoniacal & Titulometria & APHA (2002) - Método 4500C \\
\hline Nitrogênio total Kjeldahl & Titulometria & APHA (2002) - Método 4500B \\
\hline Fosfato total dissolvido & Espectrofotometria & $\begin{array}{l}\text { APHA (2002) - Item } 5 \text { do Método } \\
\text { 4500B }\end{array}$ \\
\hline Ortofosfato & Espectrofotometria & APHA (2002) - Método 4500C \\
\hline Fósforo total & Espectrofotometria & $\begin{array}{l}\text { APHA (2002) - Item } 5 \text { do Método } \\
\text { 4500B }\end{array}$ \\
\hline Silicatos Reativos & Espectrofotometria & Golterman et al. (1978) \\
\hline
\end{tabular}

\section{$\checkmark$ Sólidos Suspensos}

A concentração de sólidos suspensos, subdivididos em orgânicos e inorgânicos, foi determinada através método gravimétrico, descrito em APHA (2002) - Método 2540D e 2540E, por meio da retenção das partículas em filtros de fibra de vidro (47 mm de diâmetro e $0,5 \mu \mathrm{m}$ de porosidade), previamente calcinados e de massa conhecida ( $P 0)$.

Após filtrar uma quantidade conhecida de material (V), o conjunto (material sólido retido e o filtro) foi seco em estufa a $60^{\circ} \mathrm{C}$ por 24 horas, mantidos em dessecador até resfriar e em seguida pesados $(P 1)$. Após, foram calcinados em forno mufla a $500^{\circ} \mathrm{C}$ por 60 minutos, mantidos em dessecador até resfriar e em seguida novamente pesados $(P 2)$.

Desta forma, a concentração de sólidos suspensos pode ser calculada a partir das Equações (1), (2) e (3).

$$
\begin{aligned}
& S S T=\frac{P 1-P 0}{V} \\
& S S I=\frac{P 2-P O}{V}
\end{aligned}
$$


$S S O=\frac{P 2-P 1}{V}$

Sendo:

SST - a concentração de sólidos suspensos totais, em $\mathrm{g} \mathrm{L}^{-1}$;

$S S I$ - a concentração de sólidos suspensos inorgânicos, em $\mathrm{g} \mathrm{L}^{-1}$;

SSO - a concentração de sólidos suspensos inorgânicos, em $\mathrm{g} \mathrm{L}^{-1}$;

$P 0$ - a massa do filtro calcinado, em g;

$P 1$ - a massa do filtro com sólidos retidos secos em estufa, em g;

$P 2$ - a massa do filtro com sólidos retidos calcinados em mufla, em g;

$V$ - o volume de amostra submetida à filtração, em L.

\section{$\checkmark$ Nitrito}

A concentração de nitrito foi determinada através do método espectrofotométrico descrito em APHA (2002) - Método 4500B. Em uma alíquota de $10 \mathrm{~mL}$ de amostra, filtrada, adicionou-se, 0,2 $\mathrm{mL}$ de sulfanilamida, em seguida, após cerca de 5 minutos, adicionou-se 0,2 $\mathrm{mL}$ de N-naftil. Decorridos cerca de 10 minutos procedeu-se com a leitura em espectrofotômetro a $543 \mathrm{~nm}$, com curva previamente calibrada.

A solução de sulfamilamida foi preparada dissolvendo-se $1 \mathrm{~g}$ de sulfanilamida em $100 \mathrm{~mL}$ de ácido clorídrico (10\% v/v). Já a solução de N-naftil foi preparada pela dissolução a $0,1 \%(\mathrm{p} / \mathrm{v})$ do reagente analítico $\mathrm{N}$-naftiletilenodiamino.

\section{$\checkmark$ Nitrato}

A concentração de nitrito foi determinada através do método espectrofotométrico descrito em APHA (2002) - Método 4500D. Segundo o método, adicionou-se 0,2 mL de ácido clorídrico $1 \mathrm{~N}$ a $10 \mathrm{~mL}$ de amostra, filtrada, e procedeu-se com a leitura em espectrofotômetro a $220 \mathrm{~nm}$, com curva previamente calibrada.

\section{Nitrogênio amoniacal}

A determinação da concentração de nitrogênio amoniacal, expressa em $m g N_{\text {Amoniacal }} L^{-1}$, foi realizada através do método de titulométrico descrito em APHA (2002) - Método 4500C. Este método é realizado em duas etapas: destilação e titulação. Na primeira etapa, adicionou-se $100 \mathrm{~mL}$ de amostra, não filtrada, juntamente com $100 \mathrm{~mL}$ de água destilada e $5 \mathrm{~mL}$ de solução tampão de borato nos tubos de digestão. O volume destilado 
foi recolhido em erlenmeyers contendo $50 \mathrm{~mL}$ de ácido bórico e 3 gotas de indicador misto. A destilação ocorreu até que se alcançasse um volume de aproximadamente $125 \mathrm{~mL}$.

$\mathrm{Na}$ última etapa, o volume destilado foi titulado com ácido sulfúrico 0,01 N, utilizando-se uma bureta automática. Desta forma, a concentração de nitrogênio amoniacal na amostra pode ser calculada a partir da Equação (4).

$m g N_{\text {Amoniacal }} L^{-1}=\frac{(A-B) 280}{V}$

Sendo:

$m g N_{\text {Amon }} L^{-1}$ - a concentração de nitrogênio amoniacal, em $\mathrm{mg} \mathrm{L}^{-1}$;

$A$ - o volume de ácido sulfúrico gasto para titular a amostra, em $\mathrm{mL}$;

$B$ - o volume de ácido sulfúrico gasto para titular o branco, em mL;

$V$ - o volume inicial da amostra submetida ao ensaio, que no caso da determinação da concentração de nitrogênio amoniacal é de $100 \mathrm{~mL}$.

\section{$\checkmark$ Nitrogênio total}

A determinação da concentração de nitrogênio total, expressa em $m g N_{\text {Total }} L^{-1}$, foi realizada através do método de titulométrico descrito em APHA (2002) - Método 4500C. Este método é realizado em três etapas: digestão, destilação e titulação. Na primeira etapa, adicionou-se $50 \mathrm{~mL}$ de amostra juntamente com $10 \mathrm{~mL}$ de reagente de digestão $(134 \mathrm{~g}$ de sulfato de potássio, 7,3g de sulfato de cobre e $134 \mathrm{ml}$ de ácido sulfúrico concentrado diluído para $1 \mathrm{~L}$ ), mantendo-se o conjunto por 40 minutos a $300{ }^{\circ} \mathrm{C}$ no bloco de digestão.

Após, na segunda etapa, ou seja na destilação, adicionou-se $50 \mathrm{~mL}$ de água e 20 $\mathrm{mL}$ de hidróxido de sódio $10 \mathrm{~N}$ nos tubos de digestão. O volume destilado foi ser recolhido em erlenmeyers contendo $50 \mathrm{~mL}$ de ácido bórico e 3 gotas de indicador misto. A destilação ocorreu até que se alcançasse um volume de aproximadamente $125 \mathrm{~mL}$.

Por final, o volume destilado foi titulado com ácido sulfúrico 0,01 N, utilizandose uma bureta automática. Desta forma, a concentração de nitrogênio total pode ser calculada a partir da Equação (5).

$m g N_{\text {Total }} L^{-1}=\frac{(A-B) 280}{V}$ 
Sendo:

$m g N_{\text {Total }} L^{-1}$ - a concentração de nitrogênio total, em $\mathrm{mg} \mathrm{L}^{-1}$;

$A$ - o volume de ácido sulfúrico gasto para titular a amostra, em $\mathrm{mL}$;

$B$ - o volume de ácido sulfúrico gasto para titular o branco, em $\mathrm{mL}$;

$V$ - o volume inicial da amostra submetida ao ensaio, que no caso da determinação da concentração de nitrogênio total é de $50 \mathrm{~mL}$.

\section{Fosfato total dissolvido}

A concentração de fosfato total dissolvido foi determinada utilizando-se o método espectrofotométrico descrito em APHA (2002) - Método 4500B, especificamente o Item 5, que trata da digestão utilizando persulfato de potássio.

A $10 \mathrm{~mL}$ de amostra, filtrada, em um tubo de ensaio, adiciona-se 1 gota de fenolftaleína. Se aparecer a cor rosa, 1 gota de ácido sulfúrico 1:1 deve ser adicionada para ajuste. Adicionou-se também 0,2 $\mathrm{mL}$ da solução de ácido sulfúrico e 0,5 g de persulfato de potássio. Após, a amostra foi levar para autoclavar por 30 minutos, controlando-se a pressão em 98 e $137 \mathrm{kPa}$.

Decorridos os 30 minutos, esperou-se pelo resfriamento natural da amostra, quando novamente adicionou-se 1 gota de fenolftaleína. Em seguida, utilizando um agitador de tubos, a amostra foi neutralizada com hidróxido de sódio $10 \mathrm{~N}$, até que a coloração da amostra ficasse rosa.

Em seguida adicionou-se $4 \mathrm{~mL}$ de reagente misto e procedeu-se com a leitura em espectrofotômetro a $880 \mathrm{~nm}$, com curva previamente calibrada.

As soluções foram preparadas da seguinte maneira: fenolftaleína, através da dissolução de $5 \mathrm{~g}$ do composto em $500 \mathrm{~mL}$ de álcool etílico e $500 \mathrm{~mL}$ de água e algumas poucas gotas de hidróxido de sódio $0,02 \mathrm{~N}$ até atingir ligeira coloração rosa.

A solução de ácido sulfúrico foi preparada pela dissolução de $300 \mathrm{~mL}$ de ácido sulfúrico concentrado em $600 \mathrm{~mL}$ de água, juntamente com $4 \mathrm{~mL}$ de ácido nítrico e ajustado o volume da solução a $1 \mathrm{~L}$.

Para preparo do reagente misto foram utilizadas solução de ácido sulfúrico $5 \mathrm{~N}$, solução de antimônio tartarato de potássio (1,3715 g do composto em $500 \mathrm{~mL}$ de água), solução de molibdato de amônio (20 g do composto em $500 \mathrm{~mL}$ de água) e solução de ácido ascórbico (1,76 g do composto em $100 \mathrm{~mL}$ de água).

Para preparo de $100 \mathrm{~mL}$ de reagente misto, adiciona-se $50 \mathrm{~mL}$ da solução de ácido sulfúrico $5 \mathrm{~N}, 5 \mathrm{~mL}$ da solução de antimônio tartarato de potássio, $15 \mathrm{~mL}$ da solução de 
molibdato de amônio e $30 \mathrm{~mL}$ da solução de ácido ascórbico. Esta mistura deve ser feita obedecendo a ordem descrita, sendo que o reagente misto é estável apenas por poucas horas.

\section{$\checkmark$ Ortofosfato}

A concentração de ortofosfato foi determinada utilizando-se o método espectrofotométrico descrito em APHA (2002) - Método 4500C, utilizando-se ácido ascórbico.

Em $10 \mathrm{~mL}$ de amostra, filtrada, adicionou-se 1 gota de fenolftaleína. Caso apareça a cor rosa, 1 gota de ácido sulfúrico $5 \mathrm{~N}$ deve ser adicionada para ajustar. Já em sequencia, 4 $\mathrm{mL}$ de reagente misto foi adicionado e procedeu-se a leitura em espectrofotômetro a $880 \mathrm{~nm}$, com curva previamente calibrada.

\section{$\checkmark$ Fósforo total}

A concentração de fósforo total foi determinada utilizando-se o método espectrofotométrico descrito em APHA (2002) - Método 4500B, especificamente o Item 5, que trata da digestão utilizando persulfato de potássio. Análogo à metodologia descrita para fosfato total dissolvido, no entanto, na determinação de fósforo total utilizou-se amostra não filtrada.

\section{$\checkmark$ Silicato reativo}

A concentração de silicatos reativos foi determinada segundo o método descrito por Golterman et al. (1978), que baseia-se na formação do composto sílico-molibídico quando após redução exibe forte coloração azul.

Em $10 \mathrm{~mL}$ de amostra, filtrada, adicionou-se $1 \mathrm{~mL}$ de molibdato de sódio. Aguardou-se 15 minutos e adicionou-se 2,5 mL de ácido sulfúrico 1:1 $\mathrm{N}$, após esfriar acrescentou-se $1 \mathrm{~mL}$ de cloreto estanhoso, e após 15 minutos, procedeu-se com a leitura em espectrofotômetro a $815 \mathrm{~nm}$, com curva previamente calibrada.

A solução de molibdato de sódio foi prepara por meio da dissolução de $5 \mathrm{~g}$ do composto em $100 \mathrm{~mL}$ de ácido sulfúrico 0,5 N. A solução de cloreto estanhoso foi preparada por meio da dissolução de $40 \mathrm{~g}$ do composto em $100 \mathrm{~mL}$ de ácido clorídrico $12 \mathrm{~N}$. Pouco tempo antes de utilizar a solução deve-se diluir $1 \mathrm{~mL}$ da solução de cloreto estanhoso em 100 $\mathrm{mL}$ de água, e o restante não deve ser reutilizado. 


\section{$\checkmark$ Taxa de deposição de sólidos e nutrientes}

Para cada uma das análises anteriormente realizadas procedeu-se com cálculo das taxas de deposição daqueles elementos.

Esta taxa relaciona as características físicas das armadilhas de integração temporal, o período de incubação e a concentração dos elementos retidos na armadilha, conforme descrito por Bufon (2002), podendo ser expresso pela Equação (6).

$T D_{i}=\frac{C_{i, R} V_{A}}{A \Delta T}$

Sendo:

$T D_{i}$ - a taxa de deposição do elemento $i, \mathrm{em} \mathrm{g} \mathrm{m}^{-2} \operatorname{dia}^{-1}$;

$C_{i, R}$ - a concentração do elemento $i$ retido na armadilha de sedimentação, em $\mathrm{mg} \mathrm{L}^{-1}$;

$V_{A}$ - o volume da armadilha, que corresponde a $0,003927 \mathrm{~m}^{3}$;

$A$ - a área da abertura da armadilha, que corresponde a $0,007854 \mathrm{~m}^{2}$;

$\Delta T$ - o tempo de amostragem, 1 dia.

$i$ - os parâmetros analisados, ou seja, sólidos suspensos, nitrito, nitrato, nitrogênio amoniacal, nitrogênio total Kjeldahl, fosfato total dissolvido, ortofosfato, fósforo total e silicatos reativos.

Cabe ressaltar que houve casos que as concentrações dos elementos foram determinadas em $\mathrm{g} \mathrm{L}^{-1}, \mathrm{mg} \mathrm{L}^{-1}$ ou até mesmo em $\mu \mathrm{g} \mathrm{L}^{-1}$, havendo, desta forma, a necessidade de realizar os devidos ajustes na equação para corretamente expressar os resultados.

\subsubsection{Medição da vazão nos transectos}

Para calcular a vazão nos transectos foi utilizado o ADP - Acoustic Doppler Profiler, ou Perfilador Acústico Doppler, realizando-se, para isto, as seguintes atividades, conforme ilustrado pelo fluxograma da Figura 14. 


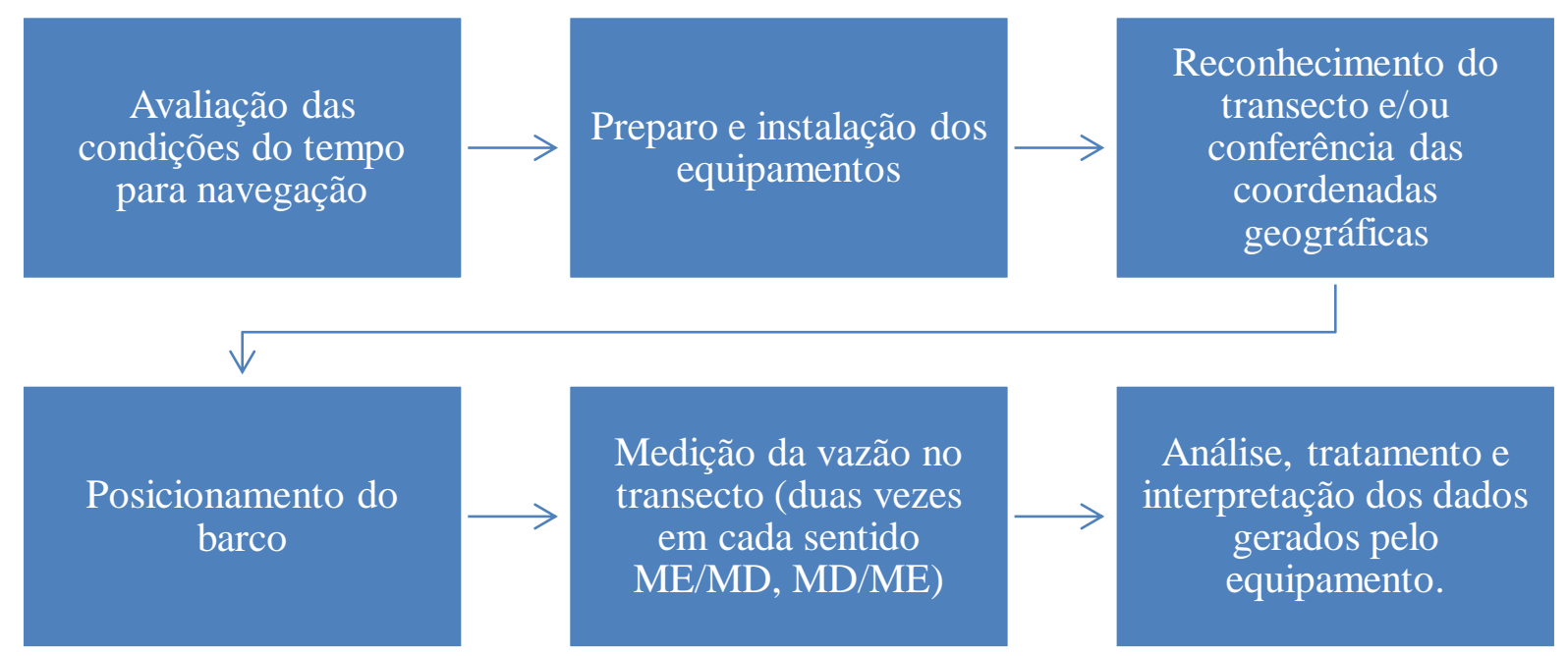

Figura 14. Fluxograma das atividades para cálculo da vazão.

O princípio de funcionamento do ADP baseia-se na captação do eco das ondas sonoras emitidas pelo aparelho que incidem sobre as partículas em suspensão (ou microorganismos) transportadas pela água. O eco captado pelos sensores do equipamento permite, por meio de processamento interno, que seja calculado a profundidade e as velocidades das partículas (ANA, 2009).

Acoplado ao ADP foi utilizado um DGPS para aquisição das coordenadas dos locais de medição bem como para subsidiar os demais cálculos internos do equipamento.

Pelo efeito doppler, o ADP calcula a velocidade, direção e profundidade da partícula em suspensão, e pode apresentar estes dados em até 128 níveis diferentes, comumente chamados de células de profundidade. Segundo a ANA (2009) é como se em cada uma destas células tivesse um molinete hidrométrico instalado (Figura 15).

Por este método, considera-se que o material em suspensão tem a mesma velocidade da corrente de água, sendo a magnitude do efeito doppler diretamente proporcional a esta velocidade. Deste modo, medindo-se a diferença de frequência entre as ondas emitidas pelo equipamento e as ondas de eco captadas pode-se determinar a velocidade da partícula, ou seja, pode-se determinar a velocidade da água (ANA, 2009). 


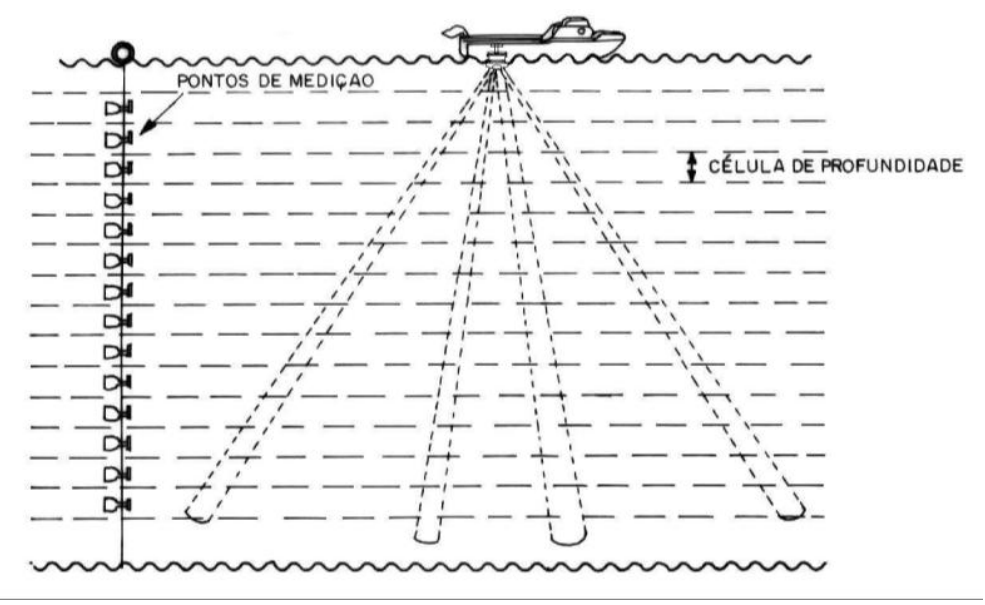

Figura 15. Representação do funcionamento de um ADP para medição da vazão de rios.

Fonte: Modificado de ANA (2009).

\subsubsection{Exportação de sólidos e nutrientes}

Inicialmente, é preciso definir o termo aqui chamado de exportação, ou também conhecido como descarga, que trata de descarga sólida através de uma seção do corpo d'água.

De qualquer maneira, exportação ou descarga, trazem consigo o mesmo conceito: relação da concentração de determinado elemento com a vazão na qual o mesmo está sendo transportado.

Assim, segundo as metodologias relacionadas na Tabela 6, após realizadas as análises, tem-se como resultado um valor que relaciona a quantidade em massa destes elementos com o volume da solução.

Agregando-se o valor da vazão do corpo d'água, na seção analisada, com a concentração desses elementos pode-se expressar a quantidade transportada em massa por unidade de tempo, por exemplo, em kg.dia ${ }^{-1}$.

De uma maneira geral o cálculo pode ser feito pela Equação (7).

$E_{i, j}=86400 C_{i, j} Q_{j}$

Sendo:

$E_{i, j}$ - a taxa de exportação do elemento $i$ no transecto $j$, em $\mathrm{g} \mathrm{dia}^{-1}$;

$C_{i, j}$ - a concentração do elemento $i$ no transecto $j$, em $\mathrm{mg} \mathrm{L}^{-1}$;

$Q_{j}$ - a vazão do transecto $j, \mathrm{em} \mathrm{m}^{3} \mathrm{~s}^{-1}$; 
$i$ - os parâmetros analisados, ou seja, sólidos suspensos, nitrito, nitrato, nitrogênio amoniacal, nitrogênio total Kjeldahl, fosfato total dissolvido, ortofosfato, fósforo total e silicatos reativos. $j-$ os transectos, $1,2,3, \ldots$.

Cabe ressaltar que houve casos que as concentrações dos elementos foram determinadas em $\mathrm{g} \mathrm{L}^{-1}, \mathrm{mg} \mathrm{L}^{-1}$ ou até mesmo em $\mu \mathrm{g} \mathrm{L}^{-1}$, havendo, desta forma, a necessidade de realizar os devidos ajustes na equação para corretamente expressar os resultados.

\subsubsection{Sedimentos de fundo}

Sedimentos são materiais não somente sólidos, mas também semissólidos que são depositados no leito de corpos d'água, lagos e reservatórios devido ao carreamento de materiais presentes na superfície do solo, por exemplo pelas águas pluviais, pela deposição da matéria orgânica em decomposição na coluna d'água, dentre outras fontes.

Desta forma, considera-se que os sedimentos são gerados em três etapas: arraste na superfície do solo, sedimentação propriamente dita e acúmulo deste material sobre o leito onde ficará depositado, camadas após camadas.

Especificamente em relação a reservatórios, segundo Carvalho et al (2000a), devido à redução da velocidade da corrente de água, os sedimentos depositam-se antecipadamente e isto diminui a capacidade de armazenamento do reservatório provocando problemas de ordem econômica, devido a redução do volume útil para geração de energia elétrica, e de ordem ambiental, por exemplo, pelos problemas gerados pelo assoreamento do corpo d'água.

No intuito de avaliar a qualidade destes sedimentos, algumas amostras, numa quantidade aproximada de $1 \mathrm{~kg}$ de sedimento úmido, foram coletadas, em cada ponto, com auxílio de uma draga de Van Veen (Figura 16) e armazenados em sacos plásticos resistentes. Essas amostras foram congeladas até o momento de suas análises em laboratório.

Segundo Figueiredo e Brehme (2000), a Draga de Van Veen é um tipo de equipamento simples, mas robusto, constituído por duas conchas articuladas por uma dobradiça, juntamente com duas barras que são conectadas aos cabos que vão até o barco. Estas conchas mantêm-se abertas até tocar o fundo do leito do rio.

Quando o cabo é recolhido as conchas se fecham e o material do leito fica retido. Este processo pode melhor ser ilustrado através da Figura 17. 


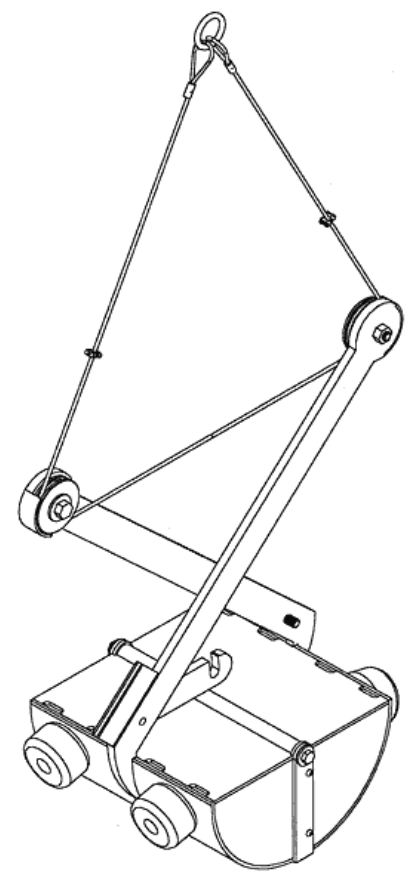

Figura 16. Draga de Van Veen.

Fonte: (KC-DENMARK, 2012).

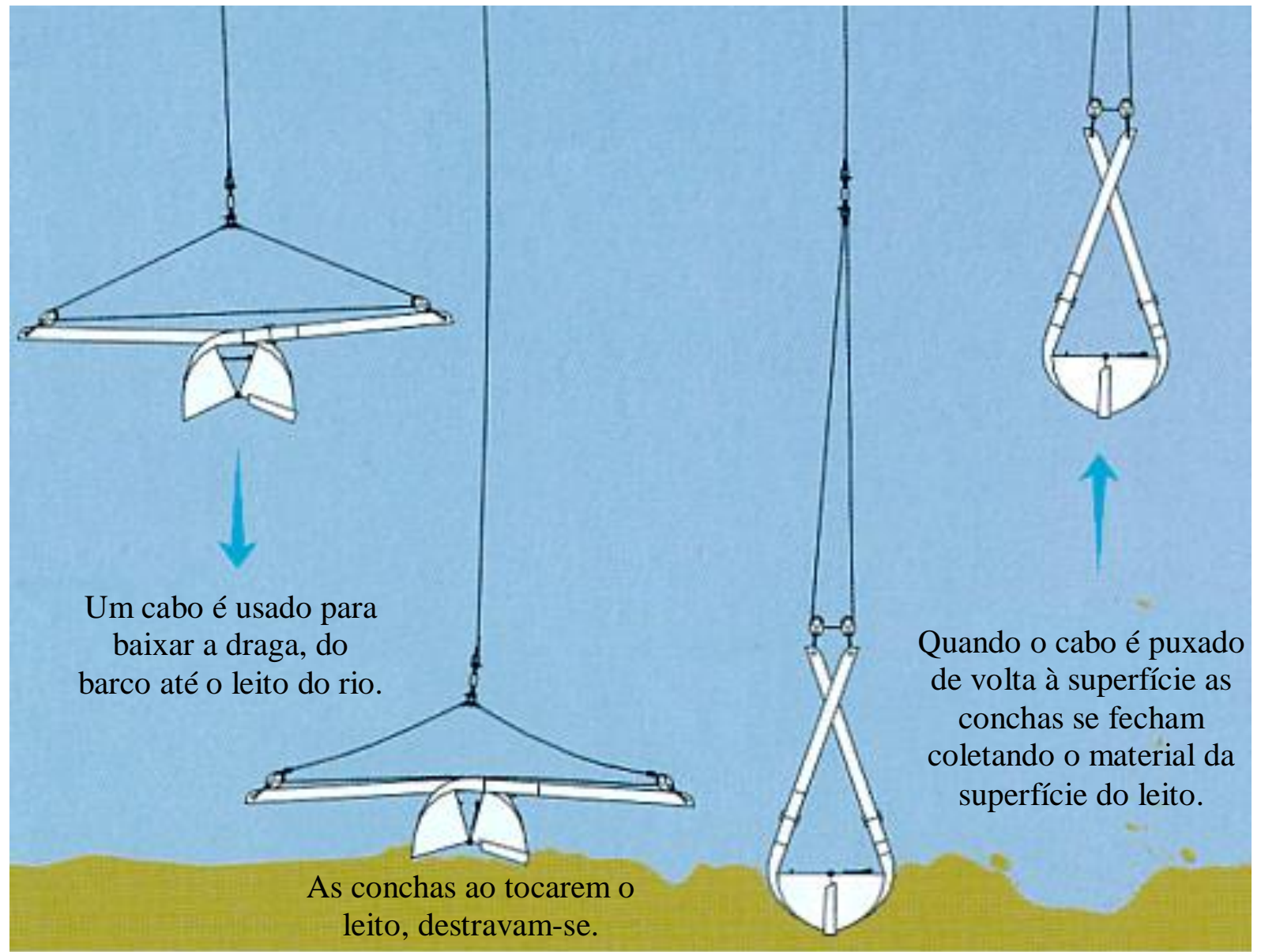

Figura 17. Esquema de funcionamento da draga de Van Veen para coleta de sedimentos. Fonte: Modificado de GEOSI (2012). 
No laboratório, as amostras foram secas em estufa a $60^{\circ} \mathrm{C}$ e foram realizadas as seguintes análises conforme metodologias descritas na Tabela 7.

Tabela 7. Amostras de sedimentos de fundo - técnicas e referências metodológicas.

\begin{tabular}{lll}
\hline Análise & Técnica & Referência \\
\hline Nitrogênio total & Titulometria & APHA (2002) \\
Fósforo total & Espectrofotometria & Andersen (1976) \\
Matéria Orgânica & Gravimetria & Trindade (1980) \\
Granulometria & Peneiramento e Densímetro & ABNT (1984) \\
\hline
\end{tabular}

\section{$\checkmark$ Nitrogênio total}

A determinação da concentração de nitrogênio total no sedimento, expressa em $m g N g^{-1}$ de sedimento, foi realizada através do método de titulométrico descrito em APHA (2002). Este método é realizado em três etapas: digestão, destilação e titulação. Na primeira etapa, adicionou-se cerca de $5 \mathrm{~g}$ de amostra seca $(P 0)$ no tubo de digestão juntamente com $10 \mathrm{~mL}$ de reagente de digestão, o conjunto foi mantido por 40 minutos a $300{ }^{\circ} \mathrm{C}$ no bloco de digestão.

Após, na segunda etapa, ou seja na destilação, adicionou-se $50 \mathrm{~mL}$ de água e 20 $\mathrm{mL}$ de hidróxido de sódio $10 \mathrm{~N}$ nos tubos de digestão. $\mathrm{O}$ volume destilado foi recolhido em erlenmeyers contendo $50 \mathrm{~mL}$ de ácido bórico e 3 gotas de indicador misto. A destilação ocorreu até que se alcançasse um volume de aproximadamente $125 \mathrm{~mL}$.

Por final, o destilado foi titulado com ácido sulfúrico $0,01 \mathrm{~N}$, utilizando-se uma bureta automática. Desta forma, a concentração de nitrogênio total no sedimento, expressa em mg de N.g ${ }^{-1}$ sedimento, foi calculada a partir da Equação (8).

$m g N g^{-1}$ de sedimento $=\frac{(A-B) 280}{P}$ 
Sendo:

$m g N g^{-1}$ de sedimento - a concentração de nitrogênio total no sedimento, em $\mathrm{mg}$ de $\mathrm{N} \mathrm{g}^{-1}$ de sedimento;

$A$ - o volume de ácido sulfúrico $0,01 \mathrm{~N}$ gasto para titular o destilado da amostra, em $\mathrm{mL}$;

$B$ - o volume de ácido sulfúrico $0,01 \mathrm{~N}$ gasto para titular o destilado do branco, em $\mathrm{mL}$;

$P$ - a massa de sedimento seco colocada no tubo de digestão, em g.

\section{Fósforo total}

A determinação da concentração de fósforo total no sedimento, expressa em

$\mu \mathrm{g}$ de $\mathrm{P}^{-1}$ de sedimento, foi feita através da metodologia descrita por Andersen (1976). O método consiste em calcinar, à $550{ }^{\circ} \mathrm{C}$ durante 1 hora, cerca de $0,2 \mathrm{~g}$ de amostra seca juntamente com 0,5 g de carbonato de sódio. Após, a mistura é colocada em um erlenmeyer e adiciona-se a solução extratora, $25 \mathrm{~mL}$ de ácido clorídrico $1 \mathrm{~N}$.

O conjunto deve ser aquecido durante 15 minutos, quando a solução começa a ficar com coloração amarelada. Após resfriar, o conteúdo deve ser transferido para um balão volumétrico de $100 \mathrm{~mL}$, completando-se o volume com água deionizada.

Uma alíquota de $6 \mathrm{~mL}$ deve ser utilizada juntamente com $1 \mathrm{~mL}$ de reagente misto para leitura em espectrofotômetro à $880 \mathrm{~nm}$, com curva previamente estabelecida.

\section{$\checkmark$ Matéria Orgânica}

O cálculo da concentração de matéria orgânica presente nos sedimentos, expresso em porcentagem, foi realizado através do método gravimétrico descrito por Trindade (1980). Segundo o método, uma amostra de aproximadamente $5 \mathrm{~g}$ de sedimento seco deve ser colocada em cadinho, previamente calcinado e pesado $(P 0)$, e submetida à secagem em estufa a $105^{\circ} \mathrm{C}$, por 24 horas. Após resfriar, em dessecador, deve ser anotado o peso do conjunto $(P 1)$. O conjunto segue para calcinação em mufla a $550{ }^{\circ} \mathrm{C}$, por $1 \mathrm{~h}$. Novamente, o peso do conjunto, após resfriar em dessecador, deve ser anotado (P2).

Desta forma, a concentração de matéria orgânica da amostra, em porcentagem, é dada pela Equação (9).

$M O=\frac{P 1-P 2}{P 1-P 0} 100$ 
Sendo:

$M O$ - a concentração de matéria orgânica na amostra, em \%;

$P 0$ - a massa do cadinho calcinado, em g;

$P 1$ - a massa do cadinho e da amostra, secos em estufa, em g;

$P 2$ - a massa do cadinho e da amostra, calcinados em mufla, em $\mathrm{g}$.

\section{$\checkmark$ Granulometria e classificação dos sedimentos}

Para determinação da curva granulométrica dos sedimentos optou-se pela metodologia da análise granulométrica conjunta, ou seja, aquela que envolve dois procedimentos, no caso, peneiramento, para partículas maiores, e densímetro, para as frações mais finas dos sedimentos, conforme descrito na NBR 7181 de 1984 - Solo: Análise Granulométrica (ABNT, 1984).

$\mathrm{O}$ ensaio por peneiramento consiste em agitar a amostra de sedimentos em um conjunto de peneiras com aberturas sucessivamente menores, sendo que no caso deste experimento foram utilizadas as seguintes: \#10 (2,000 mm), \#16 (1,180 mm), \#30 (0,600 $\mathrm{mm}), \# 40$ (0,425 mm), \#50 (0,300 mm), \#80 (0,180 mm), \#100 (0,150 mm), \#140 (0,106 mm) e \#200 (0,075 mm). Após, determina-se a quantidade de material retido em cada uma destas peneiras, em porcentagem.

Já o ensaio de sedimentação baseia-se no princípio que as partículas do solo, quando dispersas na água, sedimentam-se com velocidades diferentes dependendo de sua forma, tamanho e viscosidade da água e, por isto, utilizando-se a Lei de Stokes, pode-se calcular os diâmetros dessas que compõem a amostra.

No entanto, a análise da composição granulométrica dos sedimentos pode apresentar variabilidade elevada, pois os depósitos podem ser constituídos com partículas de decímetros de diâmetro até sedimentos compostos por partículas extremamente pequenas. Neste sentido, a análise das dimensões das partículas é particularmente importante, pois fornece subsídios para deduções significantes, por exemplo, sobre a procedência, o método de transporte, dentre outras características da matriz daquele sedimento. Por isto, devido à grande variabilidade, foram desenvolvidos diagramas ternários que permitem sua classificação.

Diagramas ternários são constituídos por triângulos nos quais, cada vértice, representa $100 \%$ de uma classe textural, seja ela areia, silte ou argila, e, desta forma, o lado oposto a esse vértice corresponde a $0 \%$ daquela classe. Existem várias classificações utilizando estes diagramas, sendo as mais comuns a classificação de Folk (1954) e a de Shepard (1954). 
Por estas propostas de classificação, segundo diagramas ternários, é possível fazer a distinção entre os tipos de sedimentos que ocorrem numa determinada área de estudo, reduzindo a ambiguidade nas comunicações científicas. Por isto, os sedimentos ainda foram classificados segundo a mais recente proposta de classificação apresentada por Flemming (2000), cujo diagrama ternário é representado pela Figura 18.

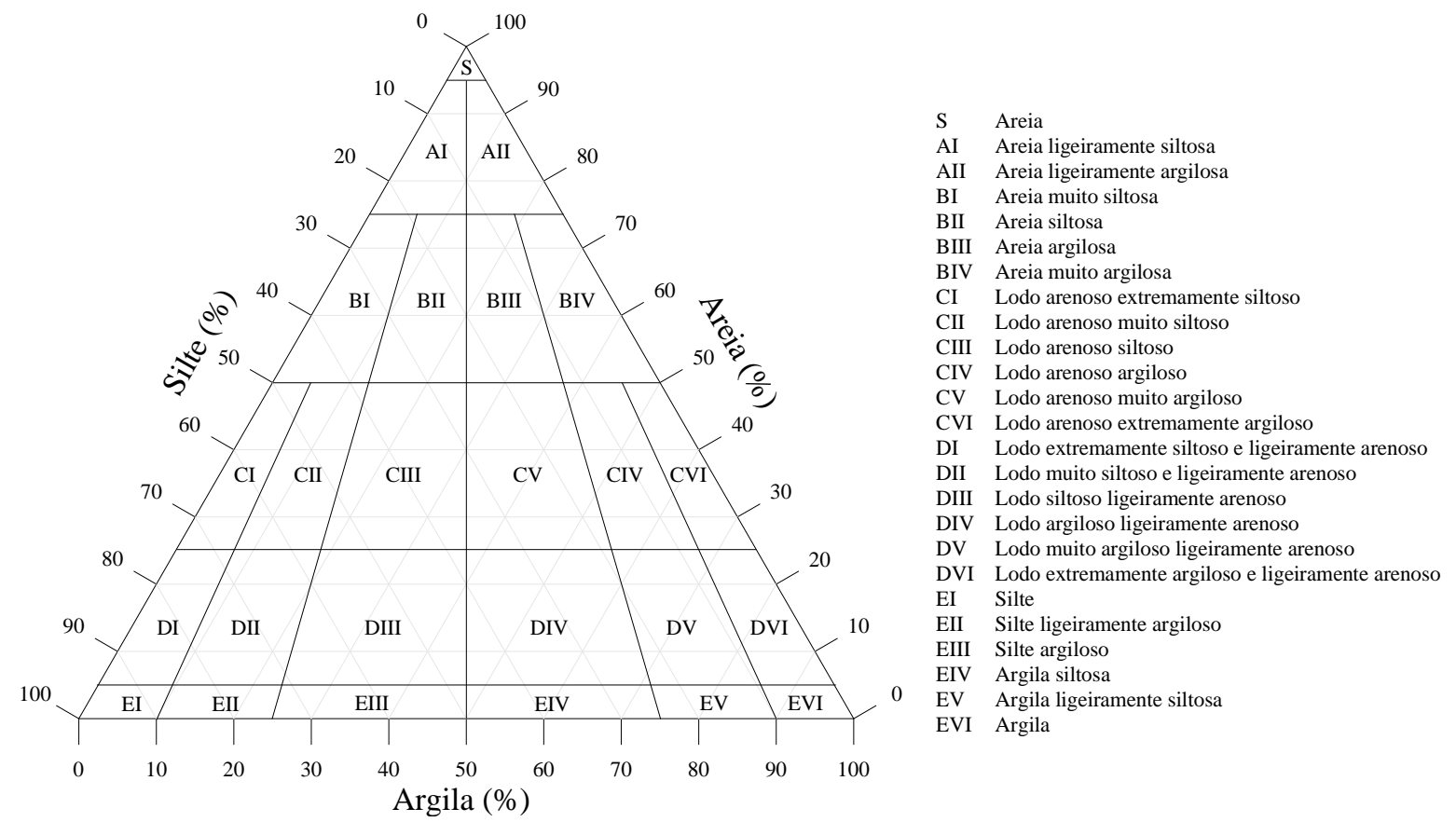

Figura 18. Diagrama ternário para classificação dos sedimentos segundo Flemming (2000). 


\section{RESULTADOS E DISCUSSÕES}

\subsection{Dados coletados in situ}

Segundo metodologia adotada para leitura dos valores das variáveis utilizando a sonda multiparâmetros YSI-6820, foi possível agrupar os resultados dessas variáveis para serem analisados por Transecto. Desta forma, os gráficos contendo os perfis verticais da concentração de oxigênio dissolvido, do pH e da temperatura, para cada um dos Transectos, nas Estações Chuvosa e Seca, foram representados nas Figuras 19 a 25, a seguir.

De antemão, foram elaboradas as Tabelas 8 e 9, as quais contêm os valores mínimos e máximos dessas variáveis observadas nas Estações Chuvosa e Seca, respectivamente.

Tabela 8. Mínimos e máximos das variáveis observadas na Estação Chuvosa.

\begin{tabular}{ccccccc}
\hline \multirow{2}{*}{ Transectos } & \multicolumn{6}{c}{ Variáveis } \\
\cline { 2 - 7 } & \multicolumn{2}{c}{ OD $\left(\mathrm{mg} \mathrm{L}^{-1}\right)$} & \multicolumn{2}{c}{$\mathrm{pH}$} & \multicolumn{2}{c}{ Temperatura $\left({ }^{\circ} \mathrm{C}\right)$} \\
$\min$ & $\max$ & $\min$ & $\max$ & $\min$ & $\max$ \\
\hline T1 & 4,60 & 6,83 & $\mathbf{6 , 4 6}$ & 6,94 & $\mathbf{2 6 , 0 8}$ & 27,80 \\
T2 & 4,98 & 7,61 & 6,91 & 7,55 & 26,20 & 30,27 \\
T3 & 4,77 & 8,60 & 6,70 & 7,61 & 25,87 & 30,45 \\
T4 & 3,99 & 8,00 & 6,64 & 7,89 & 26,90 & $\mathbf{3 0 , 6 1}$ \\
T5 & $\mathbf{0 , 8 9}$ & 7,75 & 7,03 & 8,32 & 27,04 & 29,21 \\
T6 & 3,21 & 8,26 & 7,05 & 8,38 & 26,70 & 28,99 \\
T7 & 2,83 & $\mathbf{8 , 9 0}$ & 7,17 & $\mathbf{8 , 6 7}$ & 27,17 & 28,96 \\
\hline
\end{tabular}

Tabela 9. Mínimos e máximos das variáveis observadas na Estação Seca.

\begin{tabular}{ccccccc}
\hline \multirow{2}{*}{ Transectos } & \multicolumn{6}{c}{ Variáveis } \\
\cline { 2 - 7 } & \multicolumn{2}{c}{ OD $\left(\mathrm{mg} \mathrm{L}^{-1}\right)$} & \multicolumn{2}{c}{$\mathrm{pH}$} & \multicolumn{2}{c}{ Temperatura $\left({ }^{\circ} \mathrm{C}\right)$} \\
$\min$ & $\max$ & $\min$ & $\max$ & $\min$ & $\max$ \\
\hline $\mathrm{T} 1$ & 3,05 & 3,36 & 6,68 & 6,63 & 22,83 & 22,90 \\
$\mathrm{~T} 2$ & 2,81 & 3,55 & 6,75 & 7,01 & 21,57 & 23,40 \\
$\mathrm{~T} 3$ & 2,59 & 3,74 & 6,72 & 7,18 & $\mathbf{2 1 , 2 6}$ & $\mathbf{2 4 , 5 2}$ \\
$\mathrm{T} 4$ & 2,88 & 3,77 & 6,89 & 7,45 & 21,67 & 23,27 \\
$\mathrm{~T} 5$ & 2,75 & 3,73 & 6,86 & 7,53 & 21,33 & 23,12 \\
$\mathrm{~T} 6$ & 2,54 & $\mathbf{3 , 8 7}$ & $\mathbf{6 , 6 7}$ & 7,80 & $\mathbf{2 1 , 2 6}$ & 23,05 \\
$\mathrm{~T} 7$ & $\mathbf{2 , 2 6}$ & 3,84 & 6,84 & $\mathbf{7 , 9 2}$ & 21,32 & 22,99 \\
\hline
\end{tabular}




\section{Transecto 1 - Estação Chuvosa}

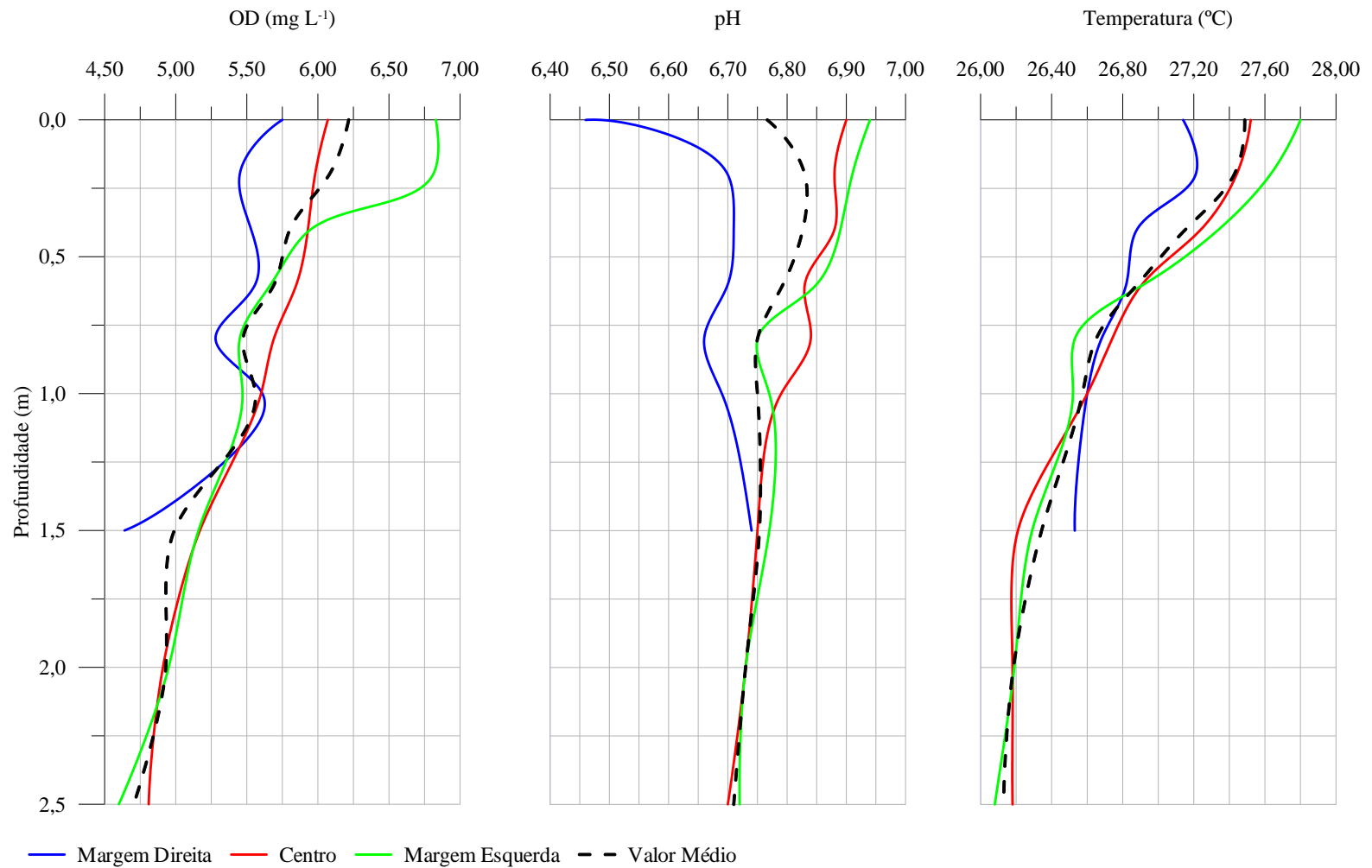

\section{Transecto 1 - Estação Seca}

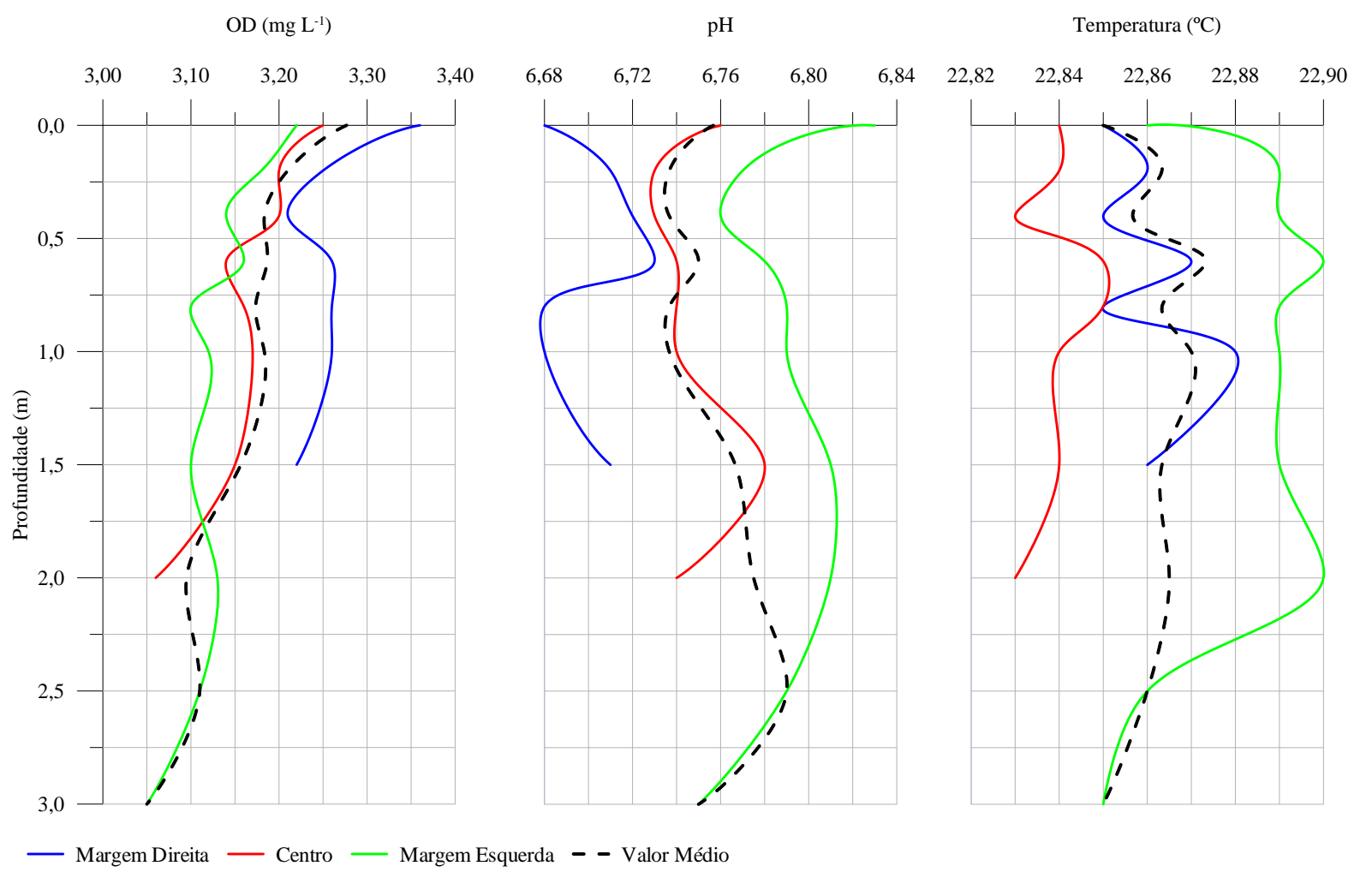

Figura 19. Perfis verticais da concentração de oxigênio dissolvido, $\mathrm{pH}$ e temperatura do Transecto 1, nas Estações Chuvosa e Seca. 
Transecto 2 - Estação Chuvosa

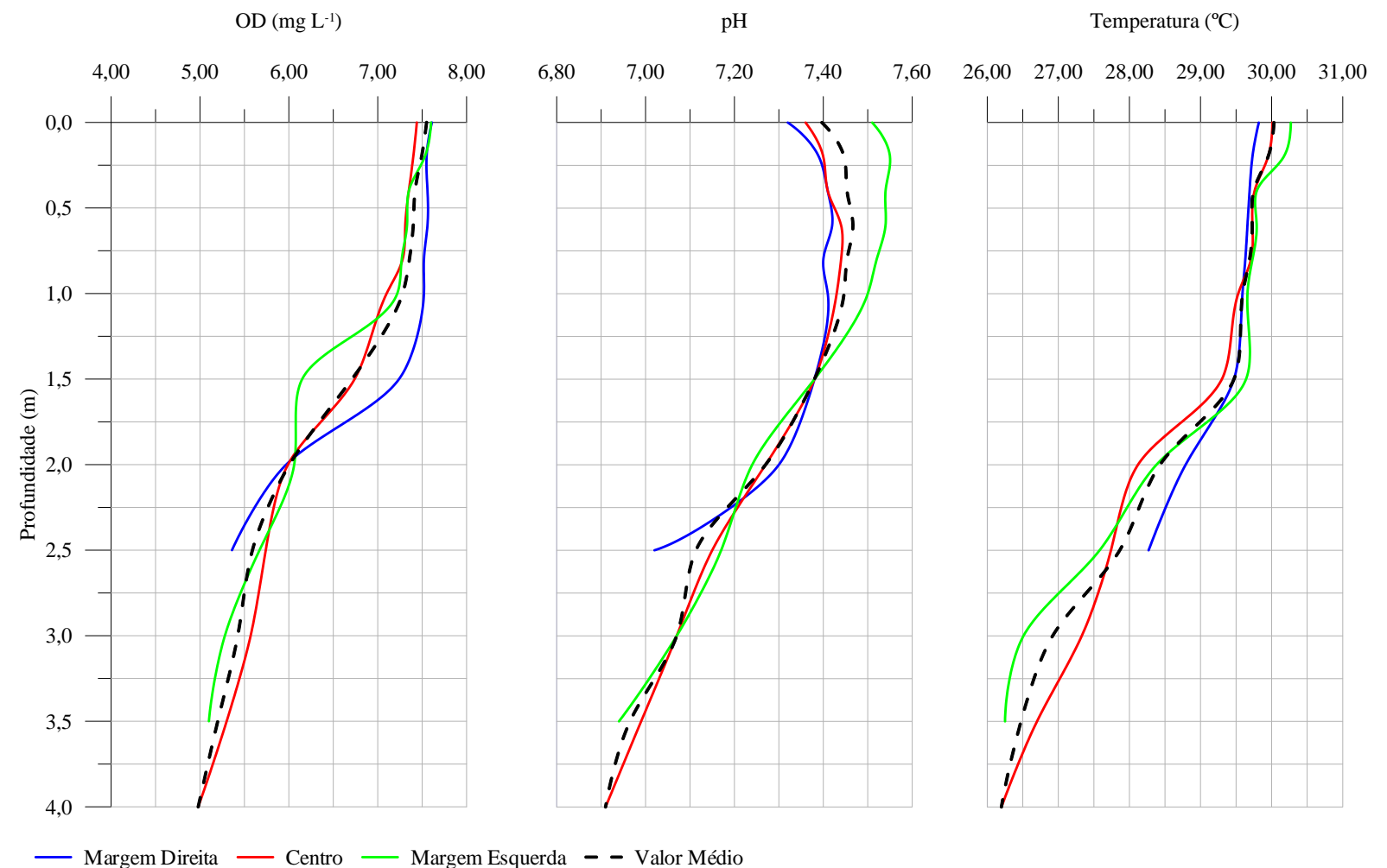

\section{Transecto 2 - Estação Seca}

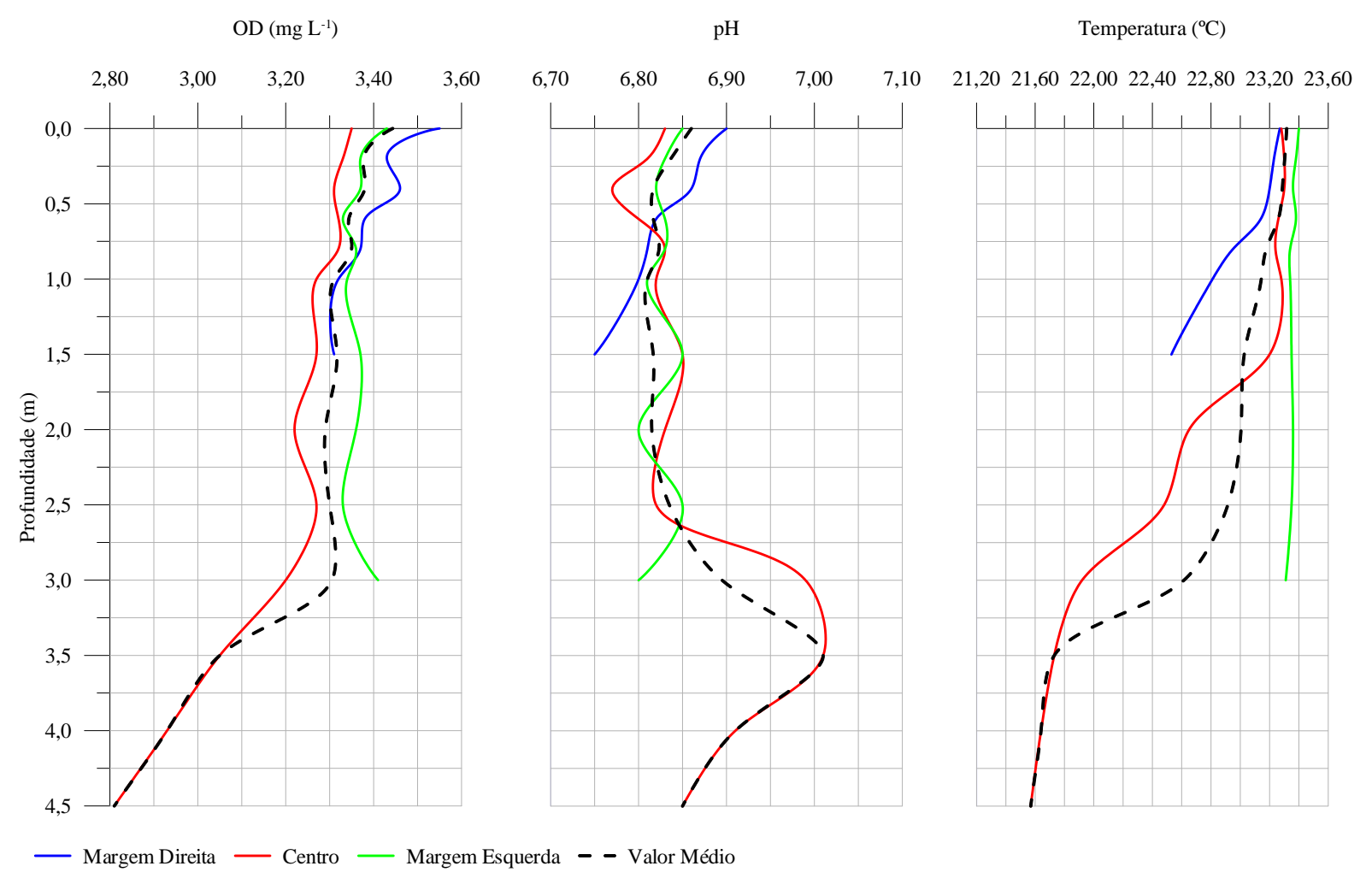

Figura 20. Perfis verticais da concentração de oxigênio dissolvido, $\mathrm{pH}$ e temperatura do Transecto 2, nas Estações Chuvosa e Seca. 


\section{Transecto 3 - Estação Chuvosa}

$\mathrm{OD}\left(\mathrm{mg} \mathrm{L}^{-1}\right)$

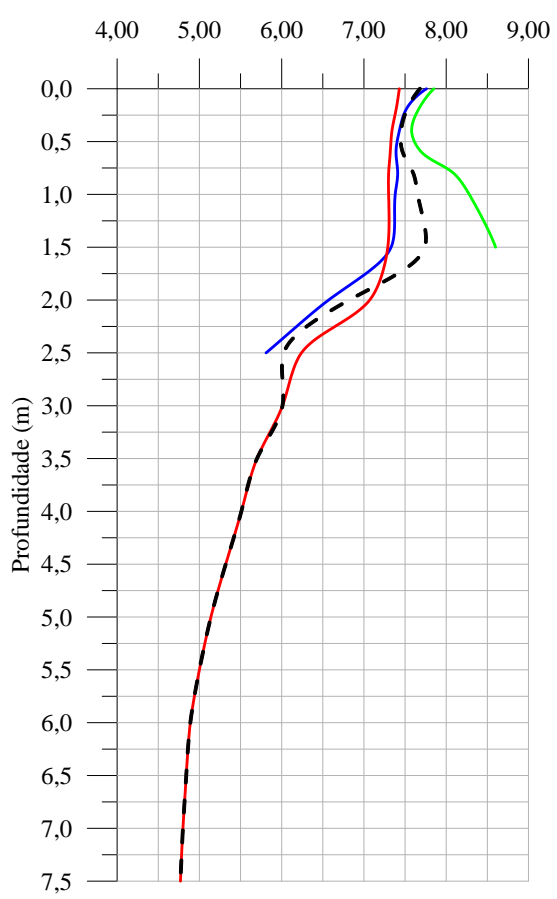

$\mathrm{pH}$
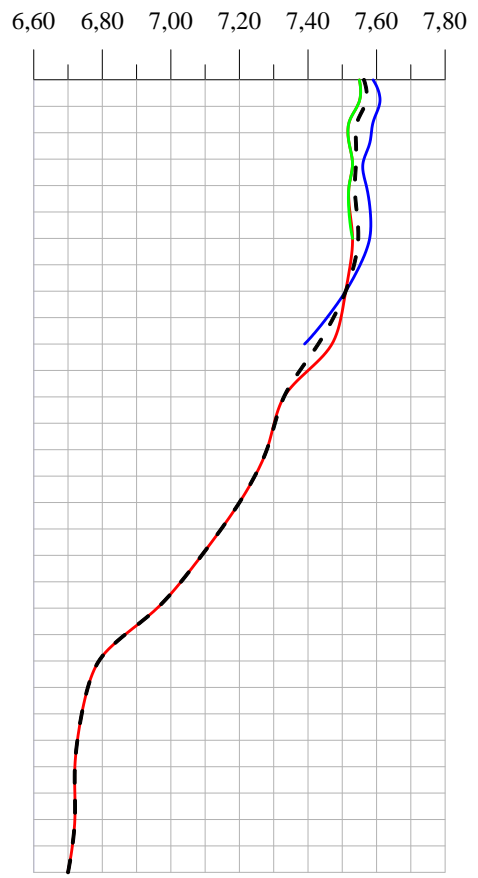

Temperatura $\left({ }^{\circ} \mathrm{C}\right)$

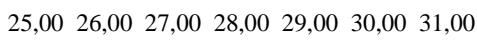

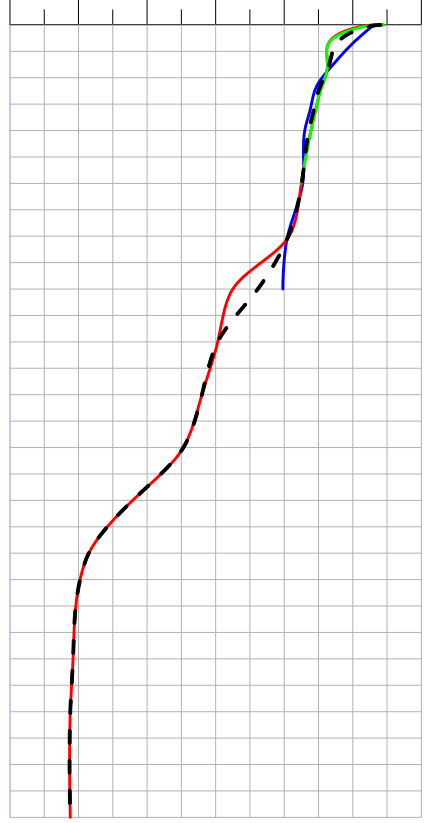

— Margem Direita — Centro — Margem Esquerda - - Valor Médio

\section{Transecto 3 - Estação Seca}

$\mathrm{OD}\left(\mathrm{mg} \mathrm{L}^{-1}\right)$

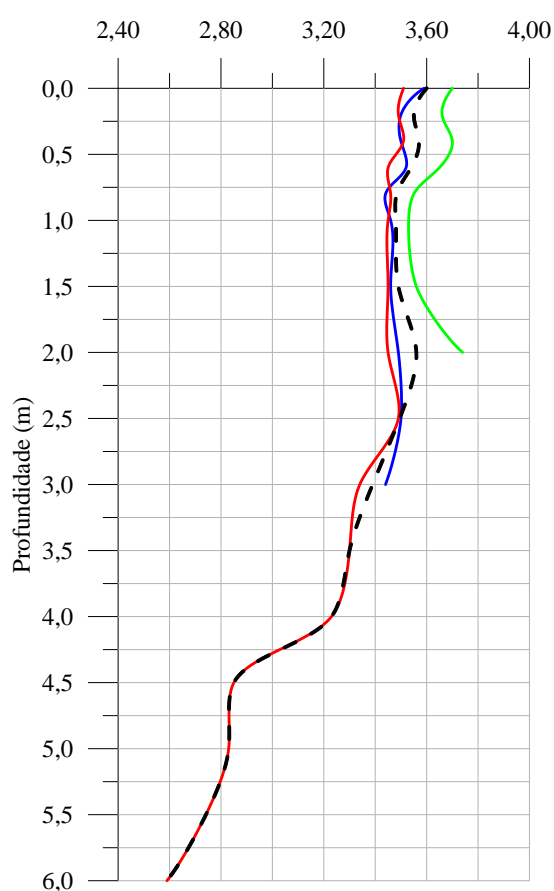

$\mathrm{pH}$
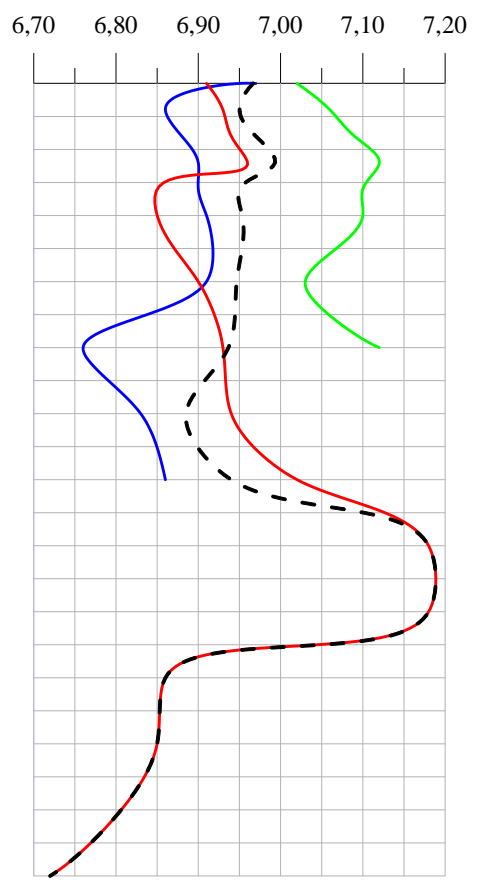

$21,00 \quad 22,00 \quad 23,00 \quad 24,00 \quad 25,00$

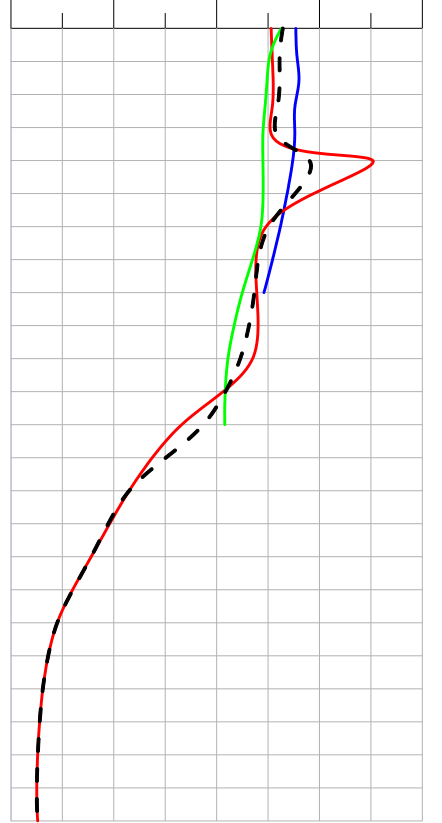

— Margem Direita — Centro — Margem Esquerda - - Valor Médio

Figura 21. Perfis verticais da concentração de oxigênio dissolvido, $\mathrm{pH}$ e temperatura do Transecto 3, nas Estações Chuvosa e Seca. 
Transecto 4 - Estação Chuvosa

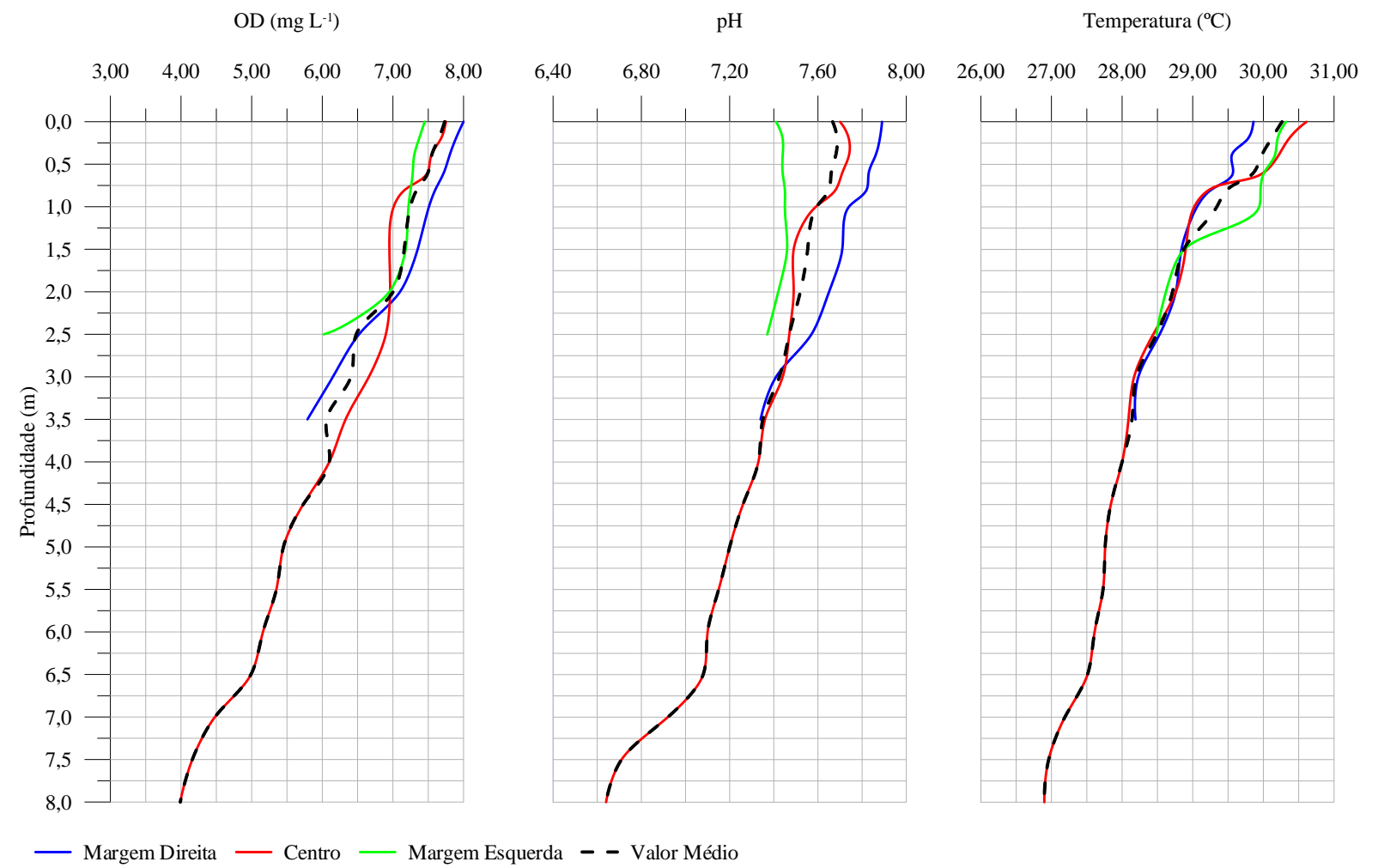

\section{Transecto 4 - Estação Seca}

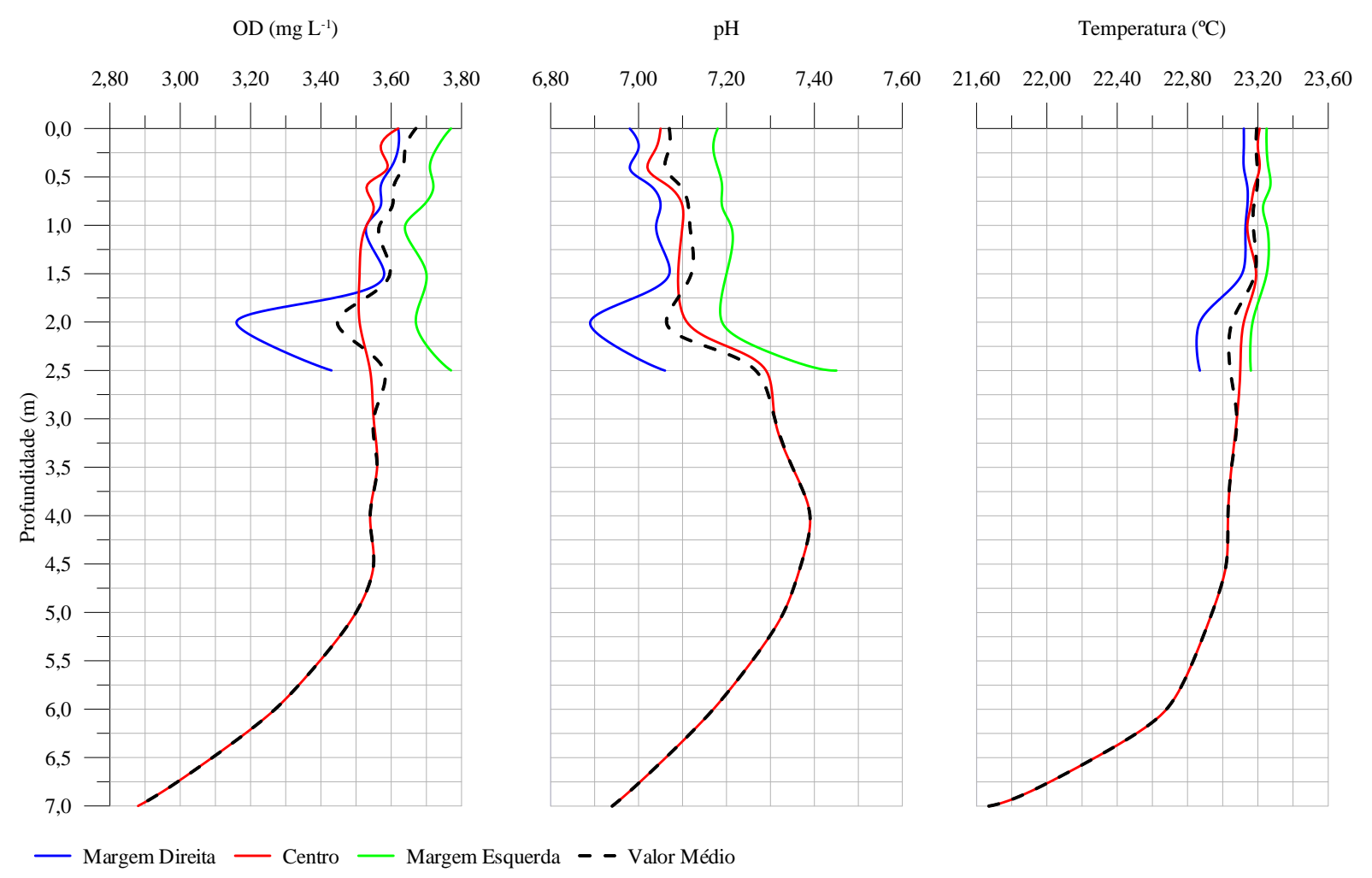

Figura 22. Perfis verticais da concentração de oxigênio dissolvido, $\mathrm{pH}$ e temperatura do Transecto 4, nas Estações Chuvosa e Seca. 


\section{Transecto 5 - Estação Chuvosa}

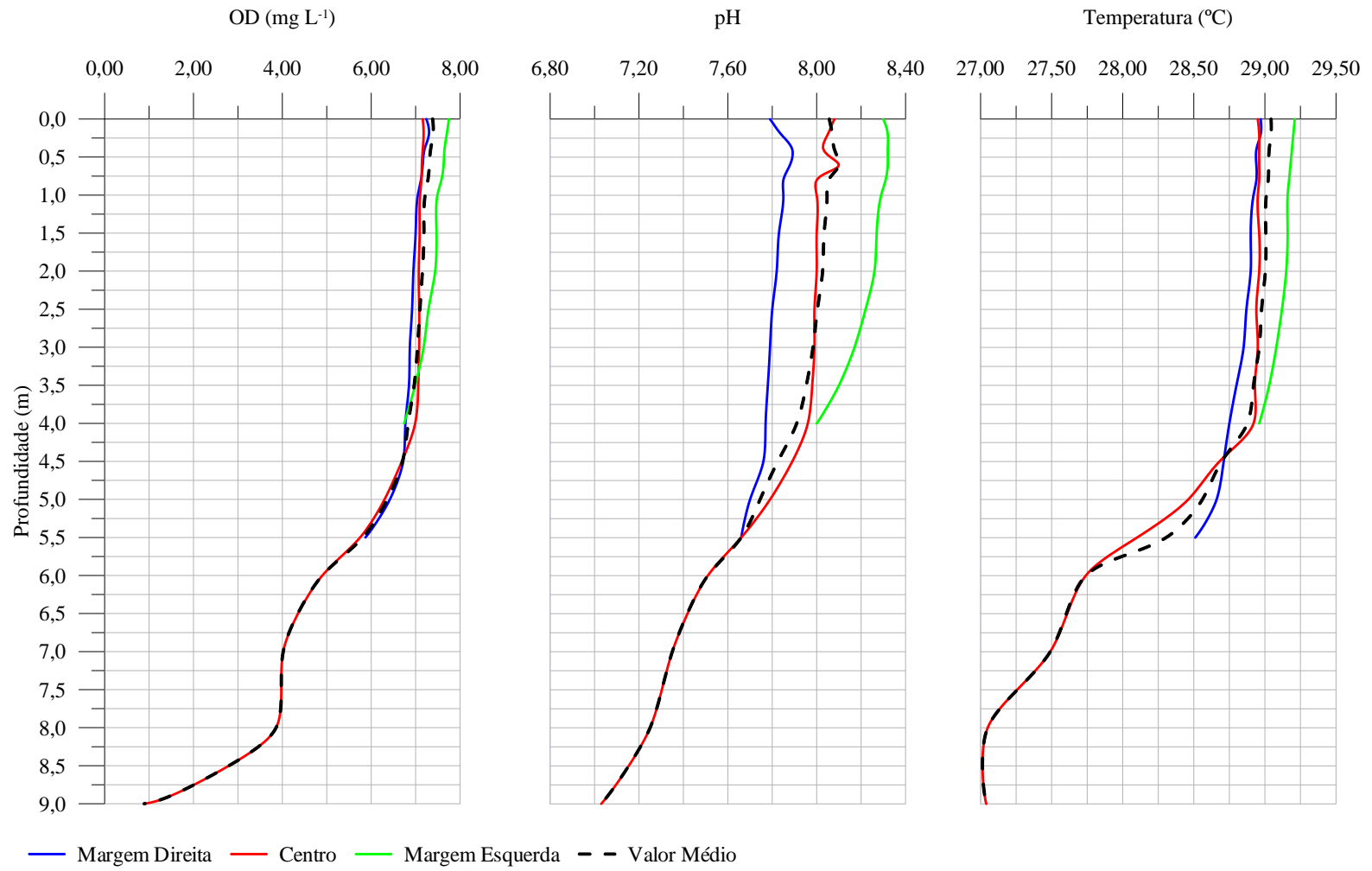

\section{Transecto 5 - Estação Seca}

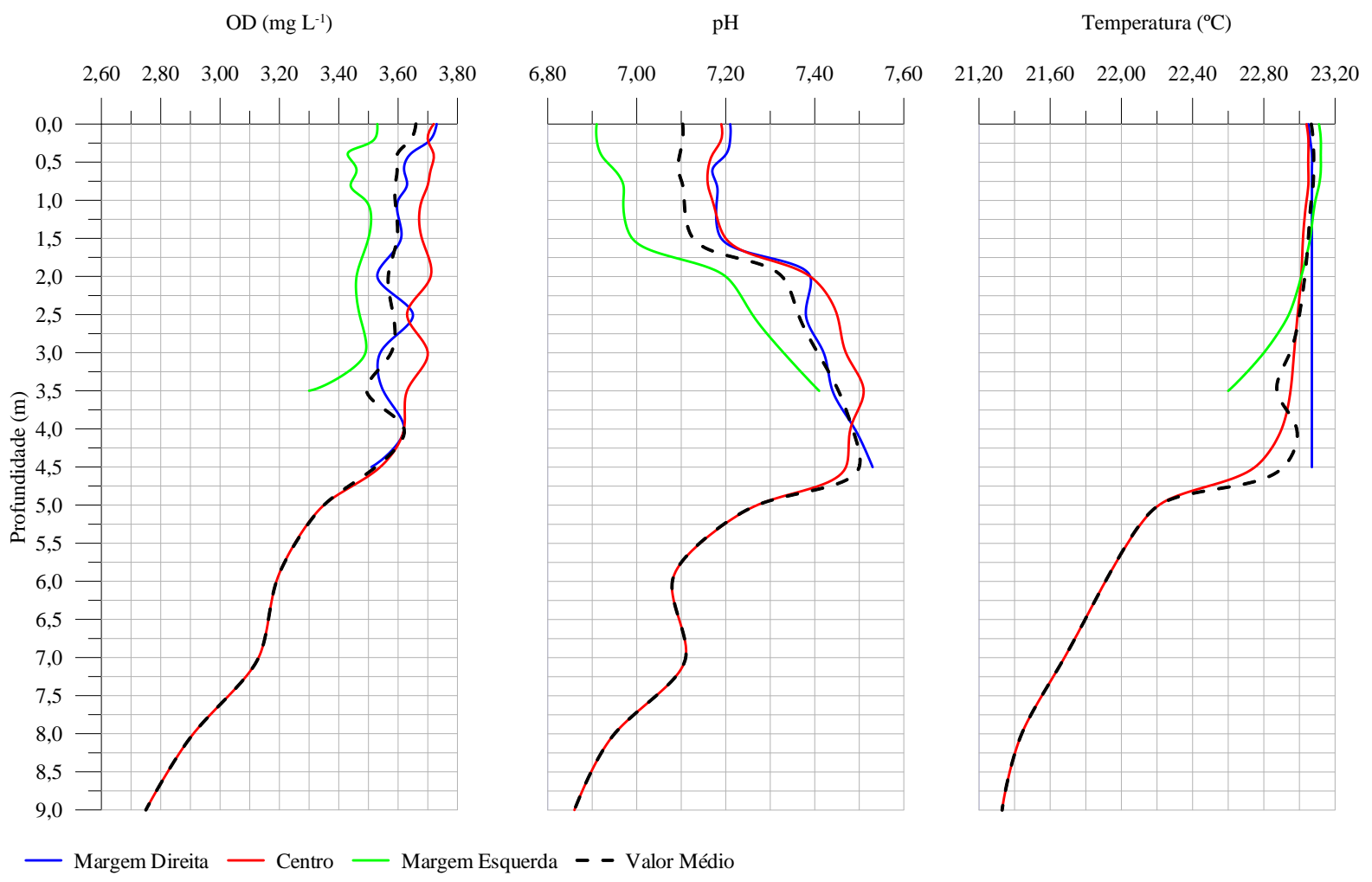

Figura 23. Perfis verticais da concentração de oxigênio dissolvido, $\mathrm{pH}$ e temperatura do Transecto 5, nas Estações Chuvosa e Seca. 
Transecto 6 - Estação Chuvosa

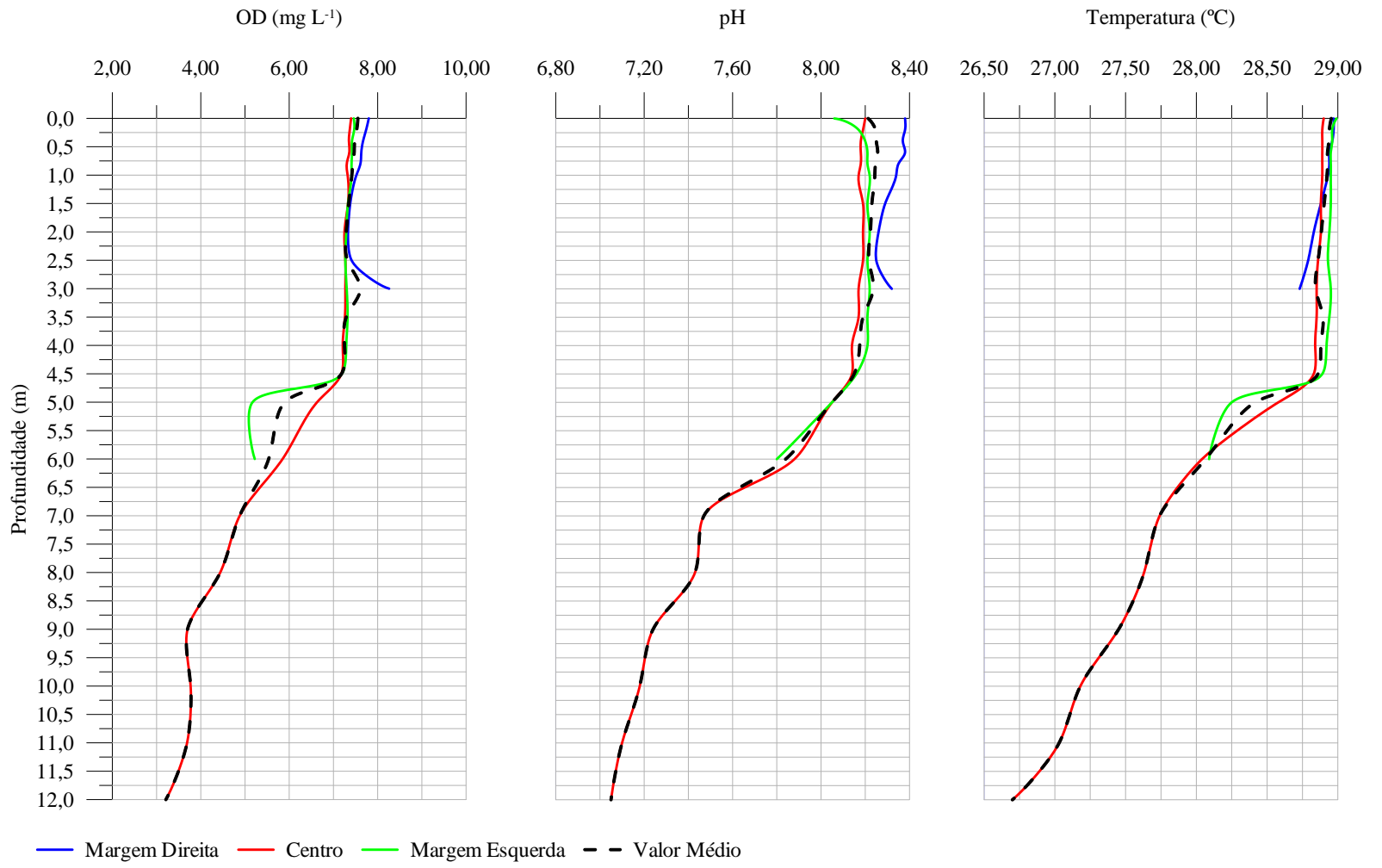

Transecto 6 - Estação Seca

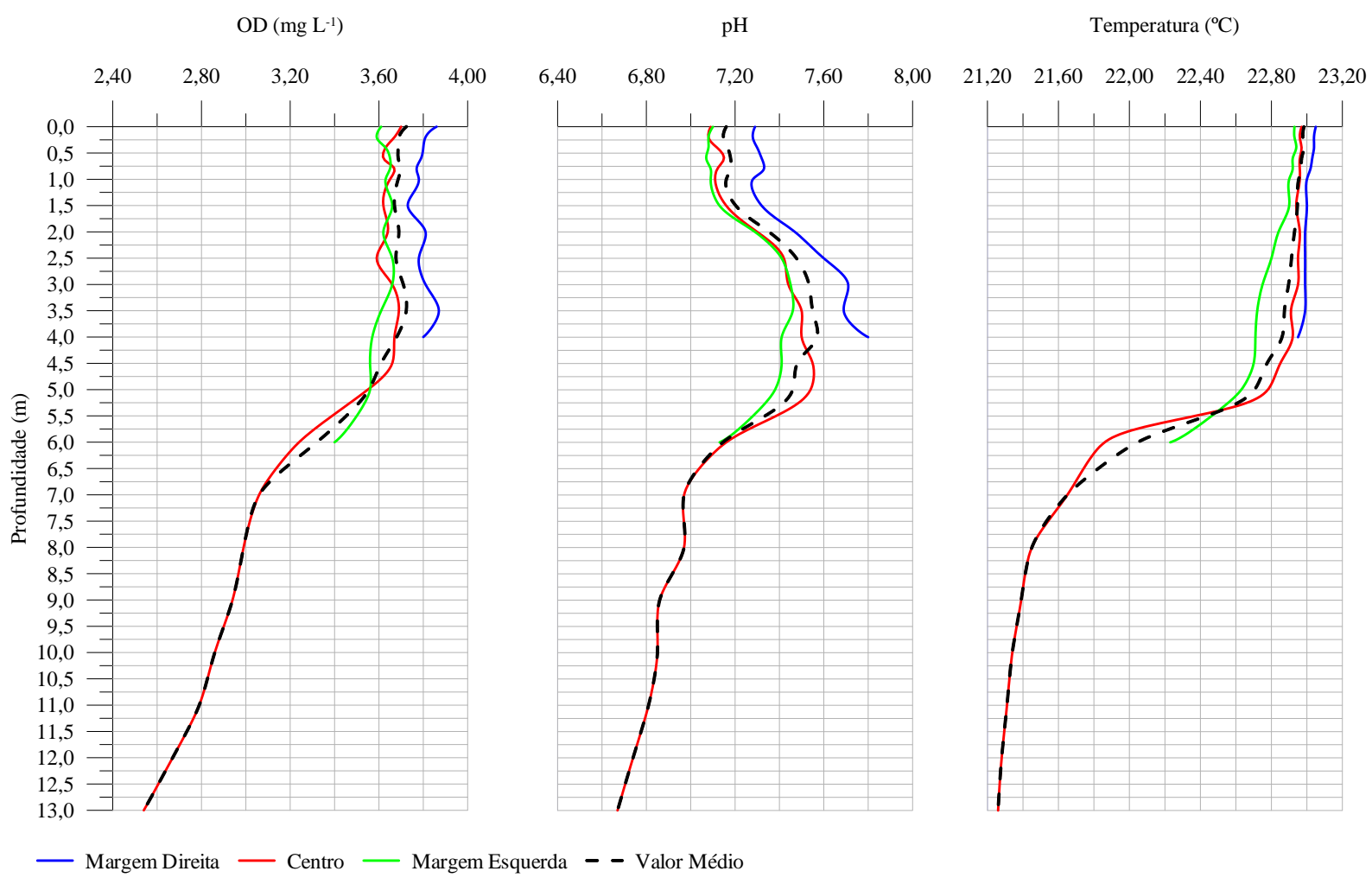

Figura 24. Perfis verticais da concentração de oxigênio dissolvido, $\mathrm{pH}$ e temperatura do Transecto 6, nas Estações Chuvosa e Seca. 
Transecto 7 - Estação Chuvosa

$\mathrm{OD}\left(\mathrm{mg} \mathrm{L}^{-1}\right)$

$\mathrm{pH}$

Temperatura $\left({ }^{\circ} \mathrm{C}\right)$
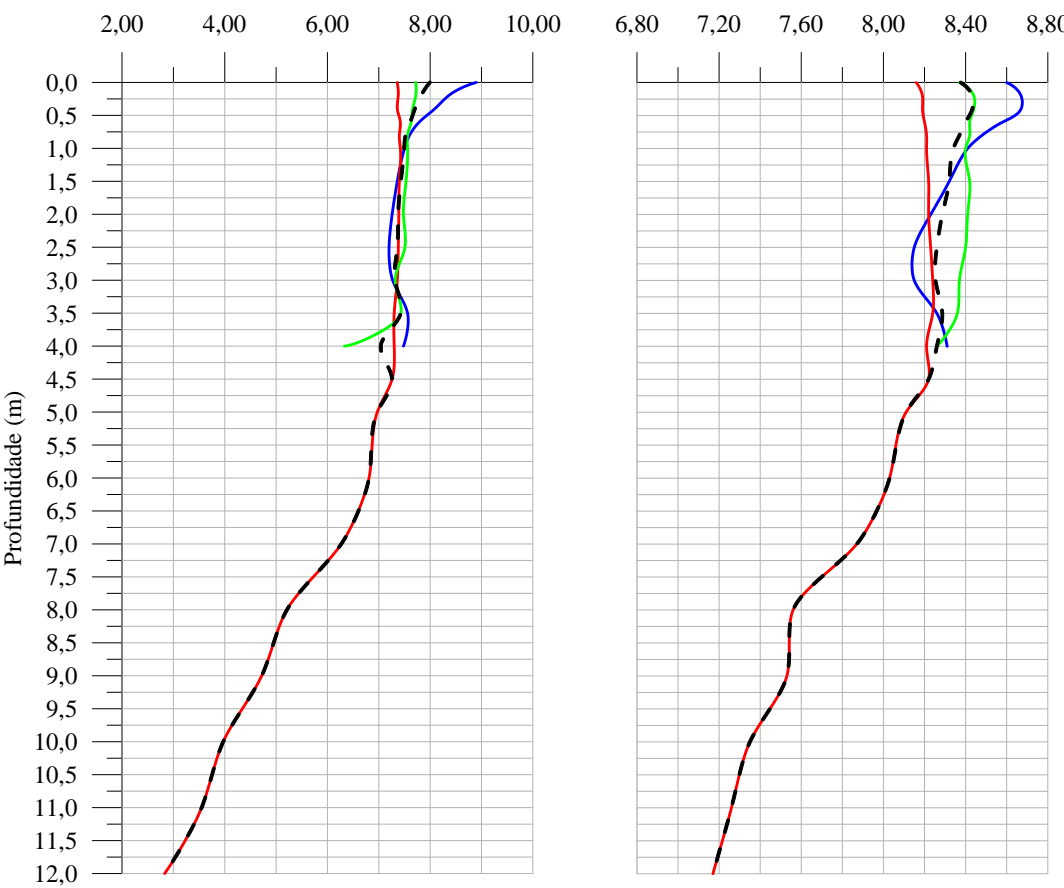

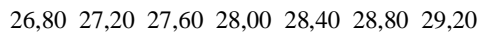

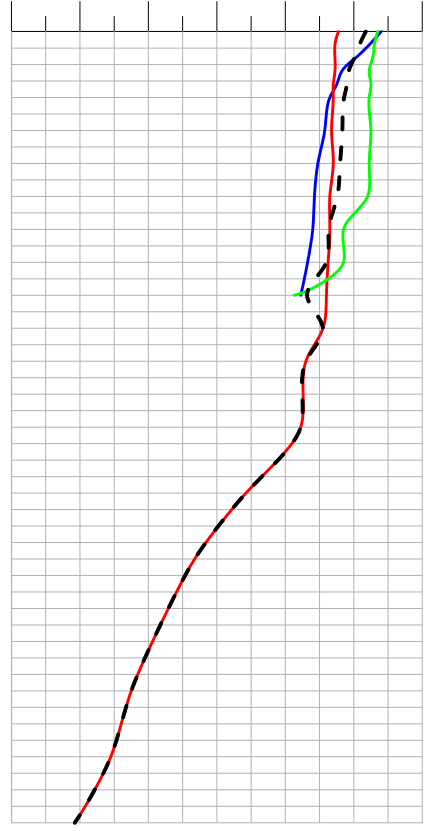

— Margem Direita — Centro — Margem Esquerda - - Valor Médio

\section{Transecto 7 - Estação Seca}

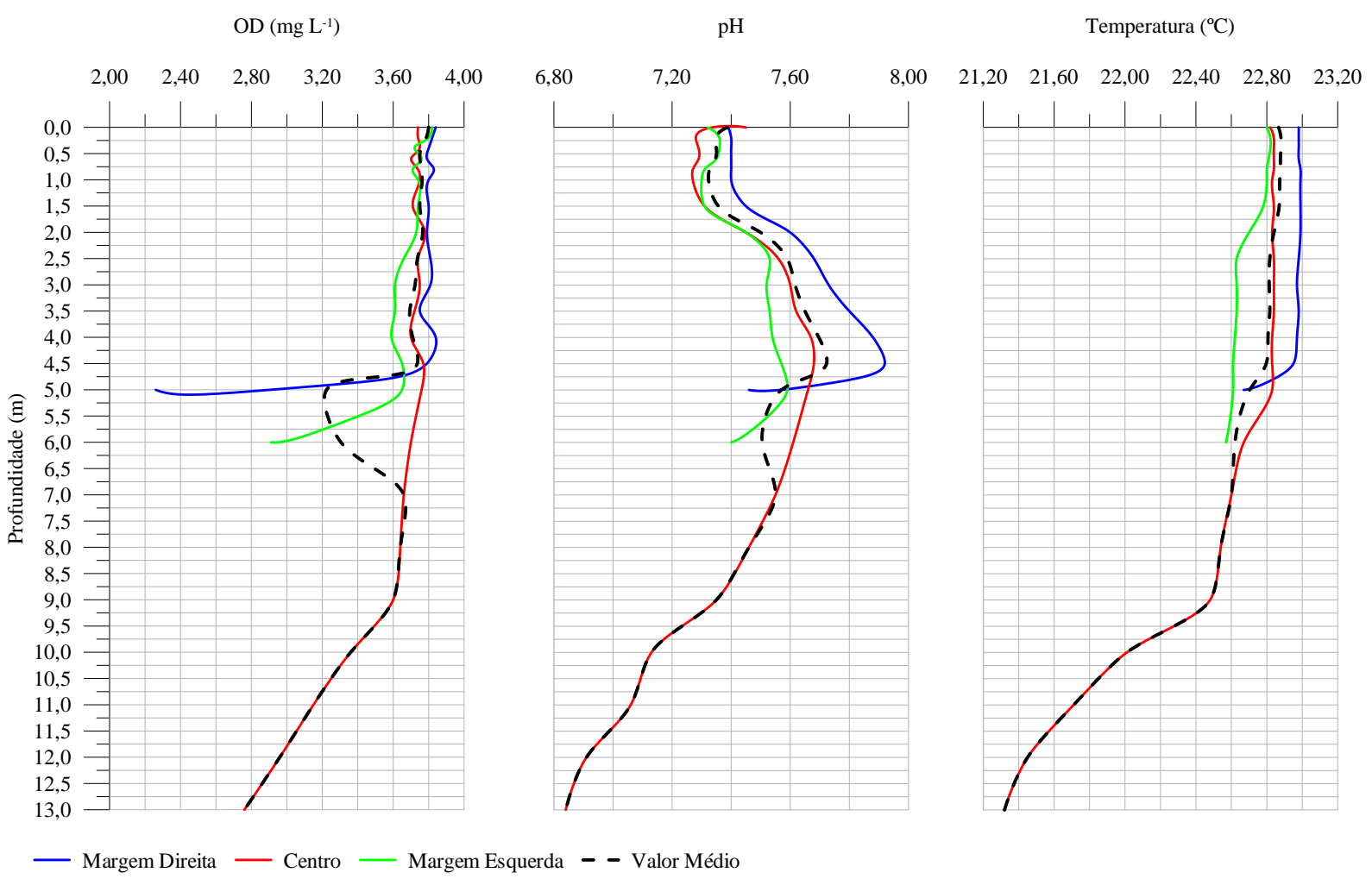

Figura 25. Perfis verticais da concentração de oxigênio dissolvido, $\mathrm{pH}$ e temperatura do Transecto 7, nas Estações Chuvosa e Seca. 
Os perfis verticais da concentração de oxigênio dissolvido demonstraram camadas próximas à condição anóxica, principalmente em locais de maior profundidade, semelhante ao constatado por Leite (1998). Por exemplo, no Transecto 5, a 9 metros de profundidade, durante a Estação Chuvosa, cuja concentração foi de $0,89 \mathrm{mg} \mathrm{L}^{-1}$, pois, por acumular maior volume de águas e maior aporte de partículas em suspensão, é capaz de tornar a água mais turva e dificultar a penetração de radiação solar inibindo a produção de oxigênio dissolvido pelos produtos primários.

Houve grande variação dos valores entre Estações, sendo que os valores ficaram em torno de $5,80 \pm 2,52 \mathrm{mg} \mathrm{L}^{-1}$ e 3,20 \pm 0,56 $\mathrm{mg} \mathrm{L}^{-1}$ nas Estações Chuvosa e Seca, respectivamente.

Em relação aos perfis térmicos, pode-se observar que durante a Estação Chuvosa a temperatura da camada superficial da água foi mais elevada que a temperatura do fundo, isto devido à incidência da radiação solar, sendo que as temperaturas variaram de 26,08 a $30,61^{\circ} \mathrm{C}, 28,02 \pm 1,69^{\circ} \mathrm{C}$. Já na Estação Seca, as variações foram menos sensíveis, e ficaram em torno de 21,26 a $24,52{ }^{\circ} \mathrm{C}, 22,46 \pm 1,04{ }^{\circ} \mathrm{C}$.

A variação da temperatura da água gera camadas de diferentes densidades que atuam como barreiras físicas e impedem que as camadas se misturem, nestas condições a energia proveniente da radiação solar não se distribui uniformemente. Segundo Esteves (1998), esta condição é chamada de estratificação térmica, sendo que em regiões tropicais, a variação de 0,1 a $0,2{ }^{\circ} \mathrm{C}$ na temperatura da água por metro de profundidade da coluna é suficiente para causar a estratificação - termoclina.

No entanto, neste trabalho, as maiores concentrações de oxigênio dissolvido ocorreram juntamente com as maiores temperaturas, ou seja, durante a Estação Chuvosa, sendo também observadas as maiores variações nas concentrações de oxigênio dissolvido $\left(5,80 \pm 2,52 \mathrm{mg} \mathrm{L}^{-1}\right)$, pois com as chuvas, ao aumentar o volume do reservatório, aumentar a concentração de sólidos em suspensão, dificulta-se a oxigenação da coluna d'água.

De modo geral os valores de $\mathrm{pH}$ apresentaram baixa variação, quando comparado com as variações observadas para as variáveis oxigênio dissolvido e temperatura. Durante a Estação Chuvosa ficaram em torno de 7,38 \pm 0,70, com valores crescentes de 6,46 no Transecto 1 a 8,67 no Transecto 7. Já durante a Estação Seca as variações foram menores ainda, com variações de 7,07 $\pm 0,44$.

Desta forma, são evidentes as alterações provocadas pelas chuvas que ocorreram durante os primeiros experimentos, e foram suficientes para provocar as variações das concentrações de oxigênio dissolvido, $\mathrm{pH}$ e temperatura. 


\subsection{Deposição de sólidos e nutrientes}

Rosa et al. $^{2}$ (1991 apud LEITE, 1998) já mencionava que o número de pesquisas envolvendo partículas em suspensão aumentava em função do reconhecimento científico da sua importância no ciclo dos nutrientes e dos poluentes, o que justifica a realização de trabalhos nesta área.

Não obstante, diversos trabalhos foram realizados utilizando-se câmaras de sedimentação dentre os quais destacam-se: Bloesch et al. (1977), em dois lagos ao norte de Lucerna, na Suiça; Maricato (1994), nos Rios Paranapanema e Taquari e no Reservatório de Jurumirim, no Alto Paranapanema/SP; Pião (1995), no Ribeirão dos Carrapatos em Itaí/SP; Marquisá (1998), no Reservatório do Lobo (ou Broa) em Itirapina/SP; Bufon (2002), na microbacia do Córrego da Barrinha em Pirassununga/SP; Leite (1998 e 2002) no Reservatório de Salto Grande em Americana/SP e Henry (2009) em duas lagoas marginais do Rio Paranapanema.

Desta forma, ressaltando a importância desses estudos, segundo as metodologias detalhadas anteriormente, as taxas de deposição foram calculadas e os resultados foram expressos graficamente, como ilustrados e detalhados a seguir.

\section{$\checkmark$ Sólidos suspensos}

A taxa de deposição de sólidos suspensos foi 153,72\% maior, em média, na Estação Chuvosa, cujos valores ficaram em torno de $29,00 \pm 20,79 \mathrm{~g} \mathrm{~m}^{-2} \mathrm{dia}^{-1}$, do que na Estação Seca, com valores de 11,43 $\pm 11,96 \mathrm{~g} \mathrm{~m}^{-2} \mathrm{dia}^{-1}$.

O valor máximo observado foi de $62,40 \mathrm{~g} \mathrm{~m}^{-2}$ dia $^{-1}$ no Transecto 2 da Estação Chuvosa, mostrando-se considerável o aporte proveniente da bacia de contribuição à montante deste Transecto, pois sozinho representa cerca 30,74\% da deposição total observada naquela Estação, conforme representado pela Figura 26.

Mas são também consideráveis as taxas de deposição observadas nos Transectos 1 e 7 da Estação Chuvosa, com 39,08 e 47,63 $\mathrm{g} \mathrm{m}^{-2} \mathrm{dia}^{-1}$, pois juntas, inclusive com as taxas do Transecto 2, representam 73,46\% da deposição total durante a Estação.

\footnotetext{
${ }^{2}$ ROSA, F. et al. Sampling the settling and suspended particulate matter (SPM). In: MUDROCH, A.; MaCKNIGHT, S. D. eds. Handbook of Techiniques for Aquatic Sediment Sampling. CRC-Press. 1991.
} 
Durante a Estação Seca ainda prevalecem as taxas dos Transectos 1 e 2, com 37,29 e 13,23 $\mathrm{g} \mathrm{m}^{-2} \mathrm{dia}^{-1}$, respectivamente, que juntas correspondem à 63,13\% da deposição total observada durante a Estação.

A taxa de deposição do Transecto 2, durante a Estação Chuvosa, de $62,40 \mathrm{~g} \mathrm{~m}^{-2} \mathrm{dia}^{-1}$, é próxima à taxa de $70 \mathrm{~g} \mathrm{~m}^{-2} \mathrm{dia}^{-1}$ encontrada por Bufon (2002), também utilizando câmaras de sedimentação. Mas é 13 vezes inferior à taxa de $900 \mathrm{~g} \mathrm{~m}^{-2} \mathrm{dia}^{-1}$ encontrada por Leite (1998). Henry (2009), em duas lagoas lateria do Rio Paranapanema, encontrou taxas de deposição de 40,1 e 411,9 $\mathrm{g} \mathrm{m}^{-2}$ dia $^{-1}$ nas Lagoas do Camargo e do Coqueiral, respectivamente.

Nestas situações, pensando-se em ações para correto manejo das áreas mais afetadas, há de atentar para as taxas observadas, por exemplo, no Transecto 1, pois as interferências que ali ocorrem referem-se à toda produção de sedimentos das áreas de cabeceiras da sub-bacia e por isto requer especial atenção, pois tais áreas estão sujeitas à grandes áreas de preservação permanente que podem estar sendo ocupadas por pastos ou com cultivo de cana-de-açúcar, em desacordo com a legislação ambiental vigente.

Já quanto ao Transecto 2, foi constatado a presença de uma grande voçoroca cujo volume de aporte de sedimentos foi suficiente para causar a maior taxa de sedimentação observada e foi amplamente discutida no trabalho de Camargo (2012).

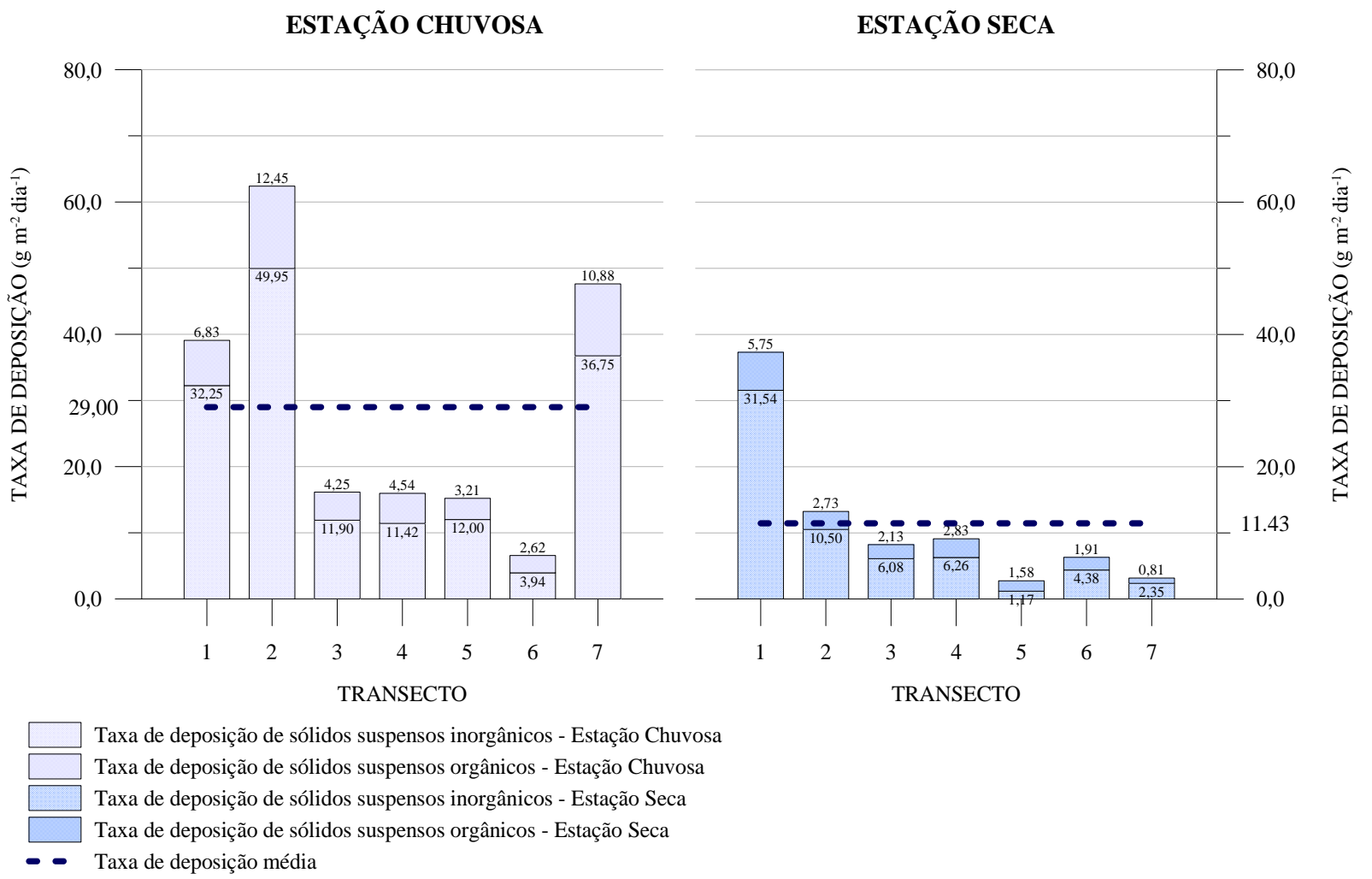

Figura 26. Taxa de deposição de sólidos suspensos - orgânicos e inorgânicos $\left(\mathrm{g} \mathrm{m}^{-2} \mathrm{dia}^{-1}\right)$. 


\section{$\checkmark$ Nitrito}

A taxa de deposição de nitrito, expressa em $\mathrm{mg} \mathrm{m}^{-2} \mathrm{dia}^{-1}$, apresentou grande variação entre as campanhas. Na Estação Chuvosa a taxa atingiu o valor máximo no Transecto 4, com 4,89 $\mathrm{mg} \mathrm{m}^{-2} \mathrm{dia}^{-1}$, quando os valores ficaram em torno de $2,89 \pm 1,51 \mathrm{mg} \mathrm{m}^{-2} \mathrm{dia}^{-1}$, ou seja, cerca de $69,03 \%$ acima da média, conforme representado pela Figura 27.

Já as taxas observadas na Estação Seca, foram significativamente menores que as taxas da Estação Chuvosa, 0,55 $\pm 0,19 \mathrm{mg} \mathrm{m}^{-2} \mathrm{dia}^{-1}$, sendo o menor valor no Transecto 4, com $0,32 \mathrm{mg} \mathrm{m}^{-2} \mathrm{dia}^{-1}$.

Isto é, além de ter sido constatado grande variações entre Estações, o Transecto foi o local no qual as variações foram mais representativas.

Contudo, em ambas as campanhas foi possível observar a tendência de acréscimo de carga entre os Transectos 1, 2, 3, sendo mais evidente, e expressivo, na Estação Chuvosa. De modo geral, as taxas de deposição na Estação Seca foram cerca de 5 vezes menor, em média, do que na Estação Chuvosa.
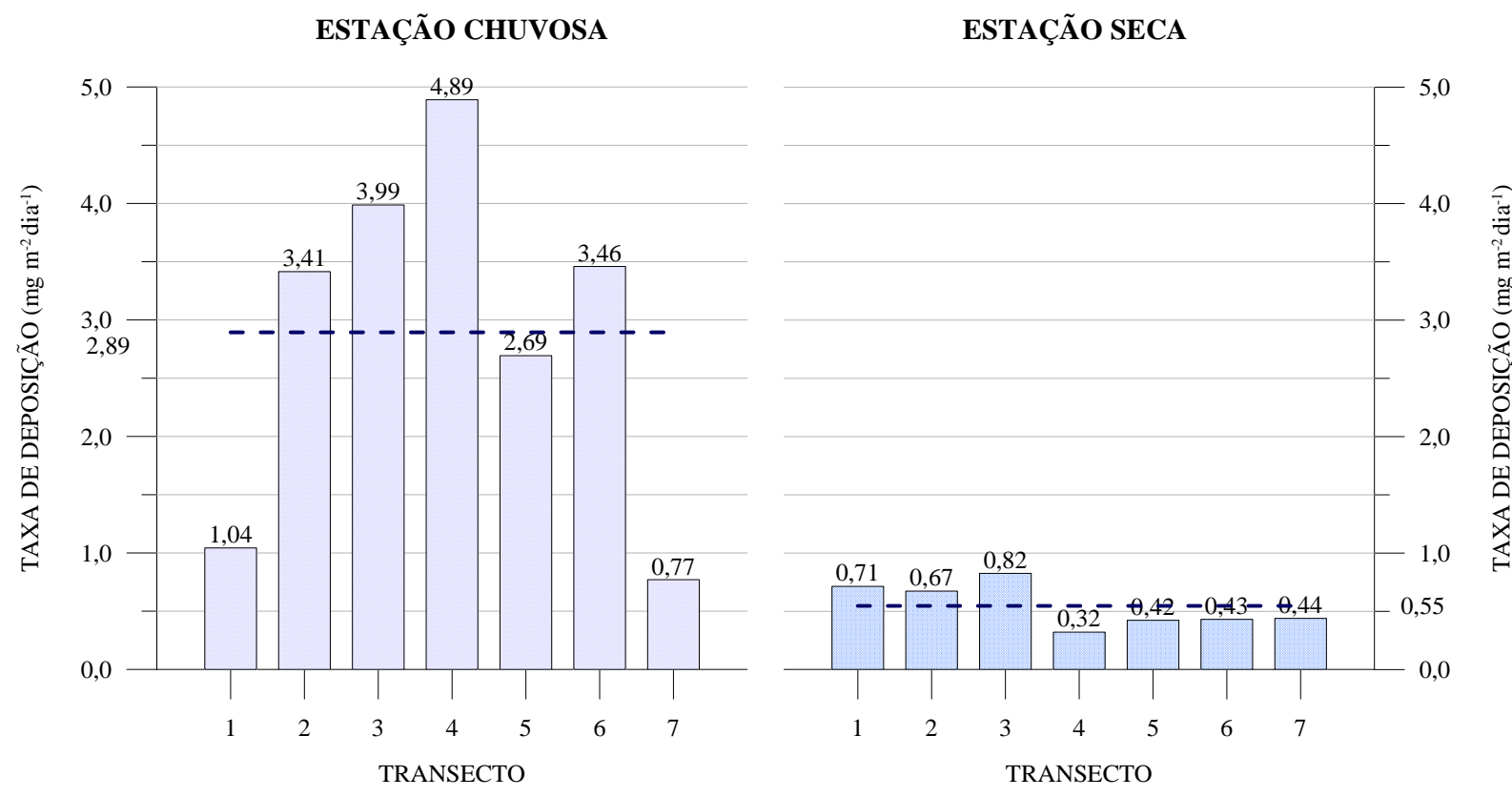

Taxa de deposição de nitrito - Estação Chuvosa

Taxa de deposição de nitrito - Estação Seca

- - Taxa de deposição média

Figura 27. Taxa de deposição de nitrito $\left(\mathrm{mg} \mathrm{m}^{-2} \operatorname{dia}^{-1}\right)$. 
$\checkmark$ Nitrato

Assim como observado para o nitrito, também se verifica a tendência crescente nas taxas de deposição de nitrato, entre os Transectos 1, 2 e 3, sendo, de maneira geral, as taxas da Estação Chuvosa 77,90\% maiores que as taxas na Estação Seca, conforme verificado na Figura 28.

Ainda destaca-se o Transecto 4, no qual, durante a Estação Chuvosa, foi observada taxa de deposição 118,25\% maior que a média da Estação.

A taxa de deposição de nitrato, durante a Estação Chuvosa, foi de 0,63 $\pm 0,34 \mathrm{~g} \mathrm{~m}^{-2} \mathrm{dia}^{-1}$. Já durante a Estação Seca, quando as taxas apresentaram comportamento praticamente crescente entre os Transectos, a taxa foi de $0,36 \pm 0,07 \mathrm{~g} \mathrm{~m}^{-2} \mathrm{dia}^{-1}$.

ESTAÇÃO CHUVOSA

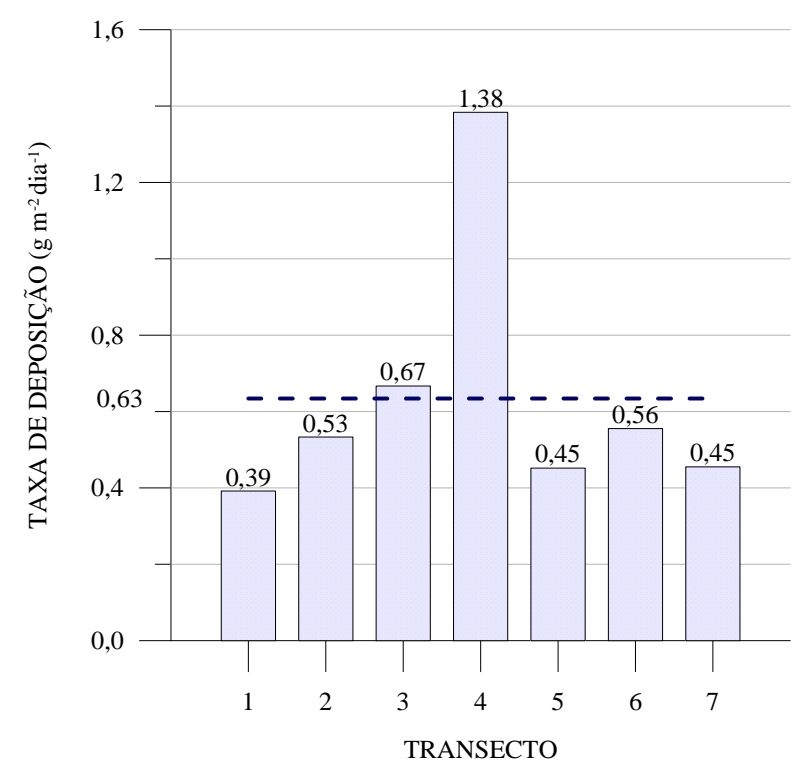

Taxa de deposição de nitrato - Estação Chuvosa

Taxa de deposição de nitrato - Estação Seca

- - Taxa de deposição média

\section{ESTAÇÃO SECA}

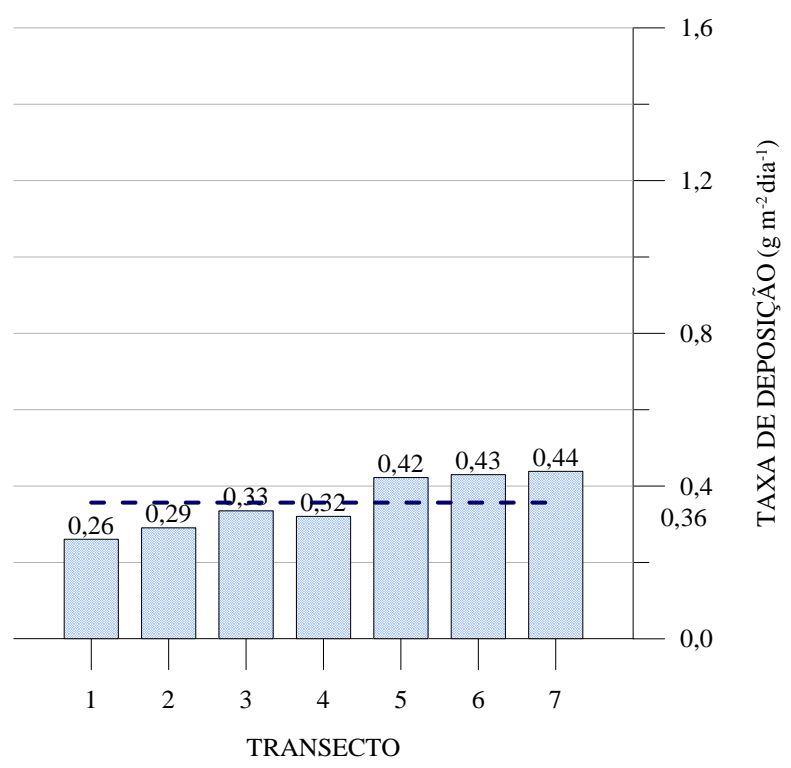

Figura 28. Taxa de deposição de nitrato $\left(\mathrm{g} \mathrm{m}^{-2} \operatorname{dia}^{-1}\right)$. 


\section{$\checkmark$ Nitrogênio amoniacal}

Conforme representado pela Figura 29, as taxas de deposição de nitrogênio amoniacal permaneceram praticamente estáveis ao longo dos transectos na Estação Chuvosa, porém apresentam tendência crescente das taxas durante a Estação Seca e com valores superiores aos observados na Estação anterior.

A menor taxa de deposição observada durante a Estação Seca foi no Transecto 2, com $0,39 \mathrm{~g} \mathrm{~m}^{-2} \operatorname{dia}^{-1}$ sendo ainda $0,01 \mathrm{~g} \mathrm{~m}^{-2}$ dia $^{-1}$ superior à taxa média de deposição da Estação Chuvosa.

Durante a Estação Chuvosa a taxa observada de deposição de nitrogênio amoniacal foi de $0,38 \pm 0,09 \mathrm{~g} \mathrm{~m}^{-2} \mathrm{dia}^{-1}$, enquanto que na Estação Seca a taxa foi de $0,60 \pm 0,19 \mathrm{~g} \mathrm{~m}^{-2} \mathrm{dia}^{-1}, 57,89 \%$ superior.

\section{$\checkmark$ Nitrogênio total Kjeldahl}

Mais estáveis que as taxas de deposição de nitrogênio amoniacal, as taxas de deposição de nitrogênio total Kjeldahl , durante a Estação Chuvosa, pouco variaram, sendo que os valores permaneceram em torno de $0,53 \pm 0,09 \mathrm{~g} \mathrm{~m}^{-2} \mathrm{dia}^{-1}$, e durante a Estação Seca as taxas foram de 2,02 $\pm 0,93 \mathrm{~g} \mathrm{~m}^{-2} \mathrm{dia}^{-1}$, cerca de $282,81 \%$ maiores que a Estação anterior, conforme representado pela Figura 30. 
ESTAÇÃO CHUVOSA

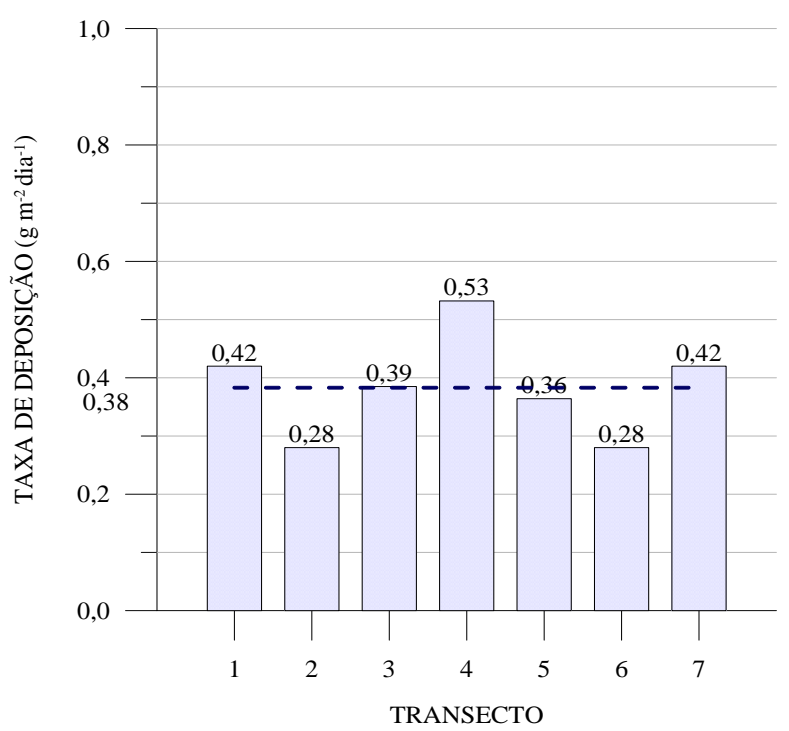

Taxa de deposição de nitrogênio amoniacal - Estação Chuvosa

Taxa de deposição de nitrogênio amoniacal - Estação Seca

- - Taxa de deposição média
ESTAÇÃO SECA

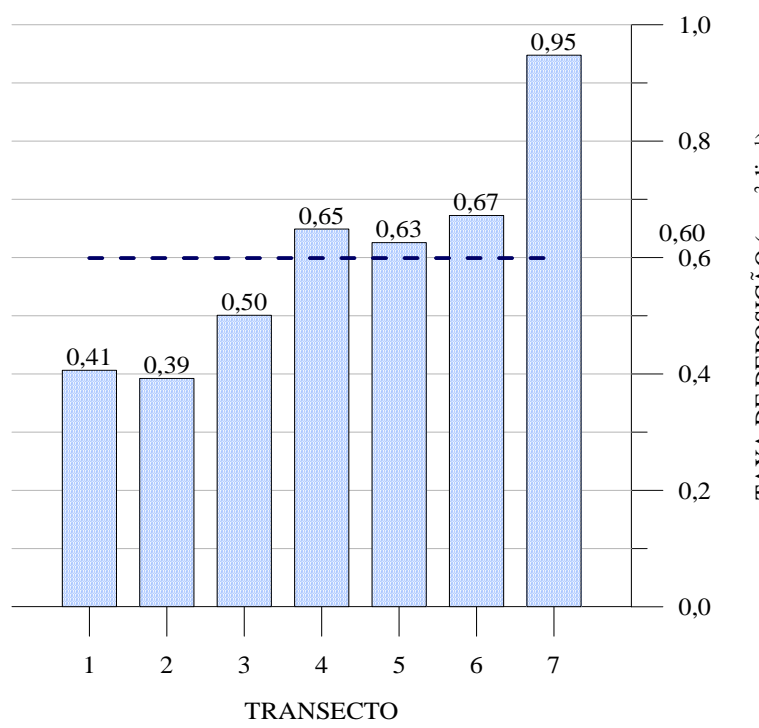

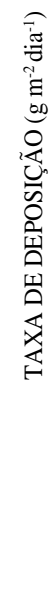

Figura 29. Taxa de deposição de nitrogênio amoniacal $\left(\mathrm{g} \mathrm{m}^{-2} \operatorname{dia}^{-1}\right)$.
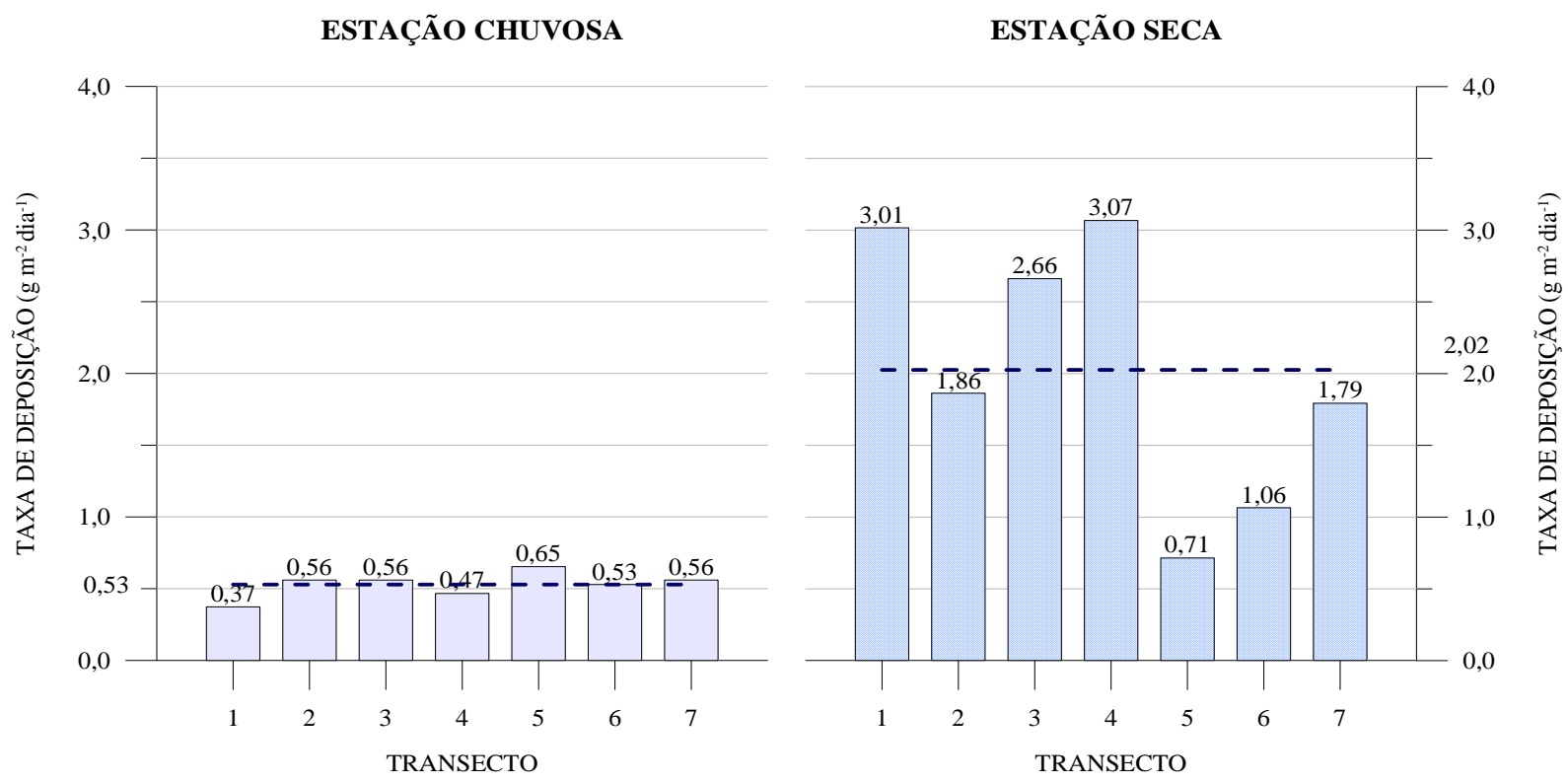

Taxa de deposição de nitrogênio total kjeldahl - Estação Chuvosa

Taxa de deposição de nitrogênio total kjeldahl - Estação Seca

- - Taxa de deposição média

Figura 30. Taxa de deposição de nitrogênio total Kjeldahl $\left(\mathrm{g} \mathrm{m}^{-2} \operatorname{dia}^{-1}\right)$. 


\section{$\checkmark$ Fosfato total dissolvido}

As taxas de deposição de fosfato total dissolvido foram 161,24\% maiores na Estação Seca, com 197,60 $\pm 144,91 \mathrm{mg} \mathrm{m}^{-2}$ dia $^{-1}$, do que na Estação Chuvosa, com $75,64 \pm 21,35 \mathrm{mg} \mathrm{m}^{-2}$ dia $^{-1}$, com destaque para o Transecto 3, da Estação Seca, cujo valor observado foi 154,21\% maior que a média da Estação, conforme ilustrado na Figura 31.

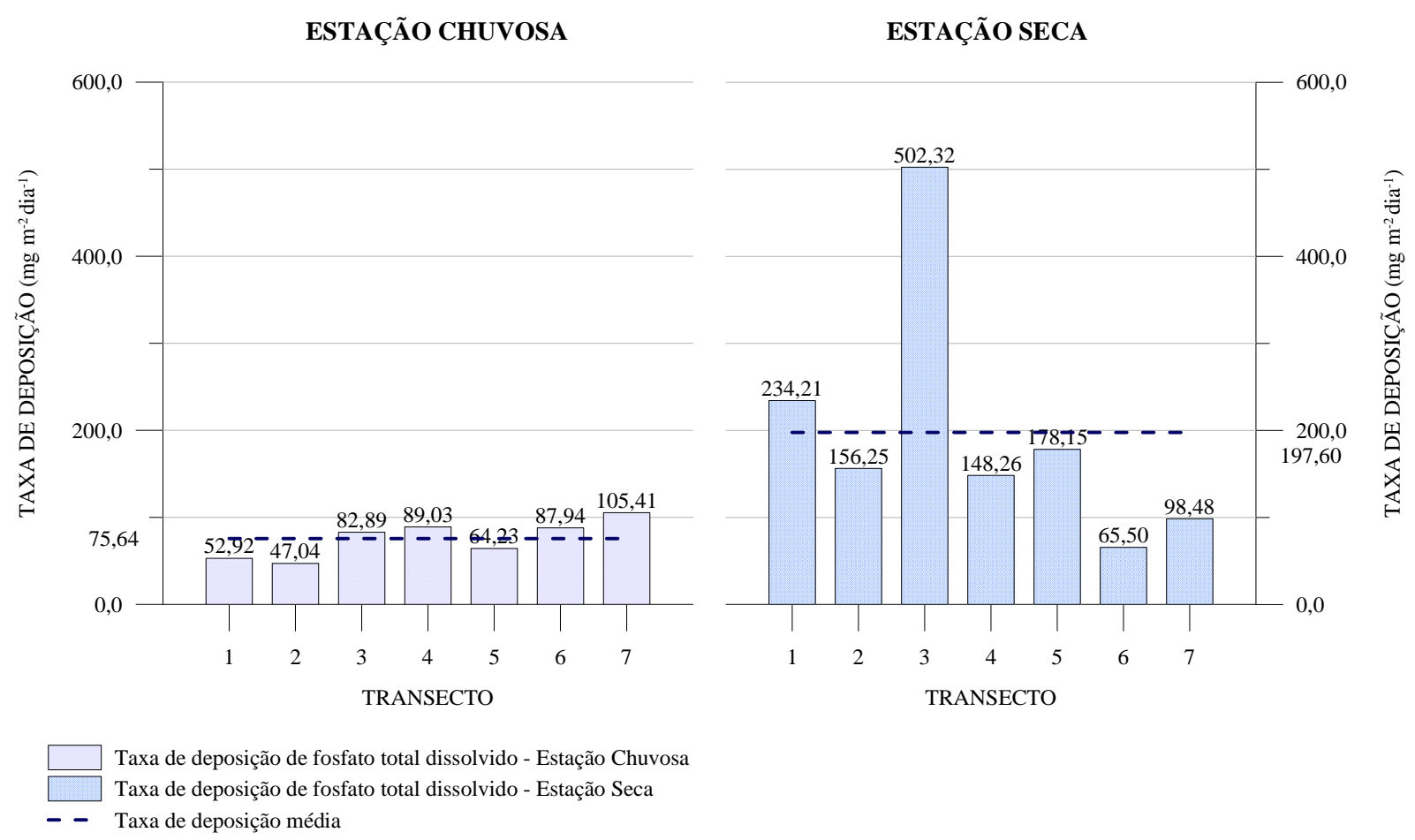

Figura 31. Taxa de deposição de fosfato total dissolvido $\left(\mathrm{mg} \mathrm{m}^{-2} \mathrm{dia}^{-1}\right)$.

O fosfato total dissolvido e ortofosfato são as formas de fósforo presentes em águas continentais, sendo o ortofosfato a principal forma assimilada por vegetais aquáticos. Geralmente, a presença desse elemento ocorre em quantidades diminutas, sendo que sua concentração depende ainda da densidade de microrganismos presentes, pois são capazes de assimilar grandes quantidades do nutriente (ESTEVES, 1998). 


\section{$\checkmark$ Ortofosfato}

As taxas de deposição de ortofosfato, como representado pela Figura 32, foram maiores, em média, na Estação Chuvosa do que na Estação Seca, cerca de 113,01\%. Durante a Estação Chuvosa destacam-se as taxas de deposição dos Transectos 1 e 7, com $4,48 \mathrm{mg} \mathrm{m}^{-2} \mathrm{dia}^{-1}$ e $5,44 \mathrm{mg} \mathrm{m}^{-2} \mathrm{dia}^{-1}$, pois foram $44,05 \%$ e $74,92 \%$ maiores que a média da Estação, respectivamente.

Acompanhando as taxas observadas na Estação Chuvosa, as taxas dos Transectos 1 e 2 durante a Estação Seca foram 188,36\% e 116,44\% maiores que a média da Estação, respectivamente.

No geral, as taxas de deposição de ortofosfato foram de $3,11 \pm 1,33 \mathrm{mg} \mathrm{m}^{-2} \mathrm{dia}^{-1}$ na Estação Chuvosa e de 1,46 $\pm 1,58 \mathrm{mg} \mathrm{m}^{-2}$ dia $^{-1}$ na Estação Seca.

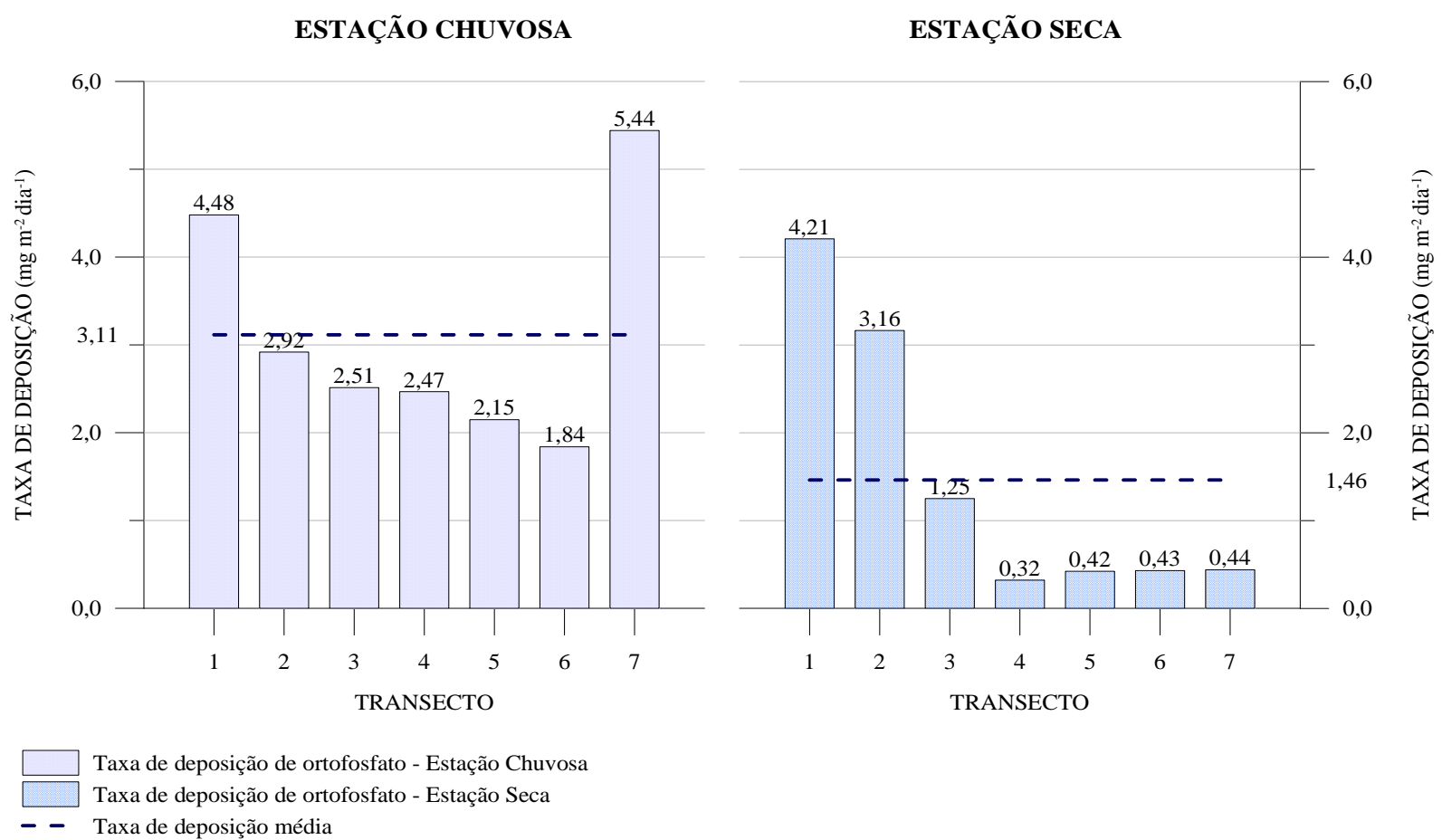

Figura 32. Taxa de deposição de ortofosfato $\left(\mathrm{mg} \mathrm{m}^{-2} \operatorname{dia}^{-1}\right)$. 


\section{Fósforo total}

Apesar das taxas de deposição de fósforo total durante a Estação Chuvosa, com valores de $139,67 \pm 60,76 \mathrm{mg} \mathrm{m}^{-2} \mathrm{dia}^{-1}$, terem sido $34,44 \%$ superiores, em média, às taxas da Estação Seca, com 103,89 $\pm 93,56 \mathrm{mg} \mathrm{m}^{-2} \mathrm{dia}^{-1}$, o maior valor encontrado foi durante a Estação Seca, no Transecto 7, com 299,72 $\mathrm{mg} \mathrm{m}^{-2}$ dia $^{-1}$, conforme representado na Figura 33.

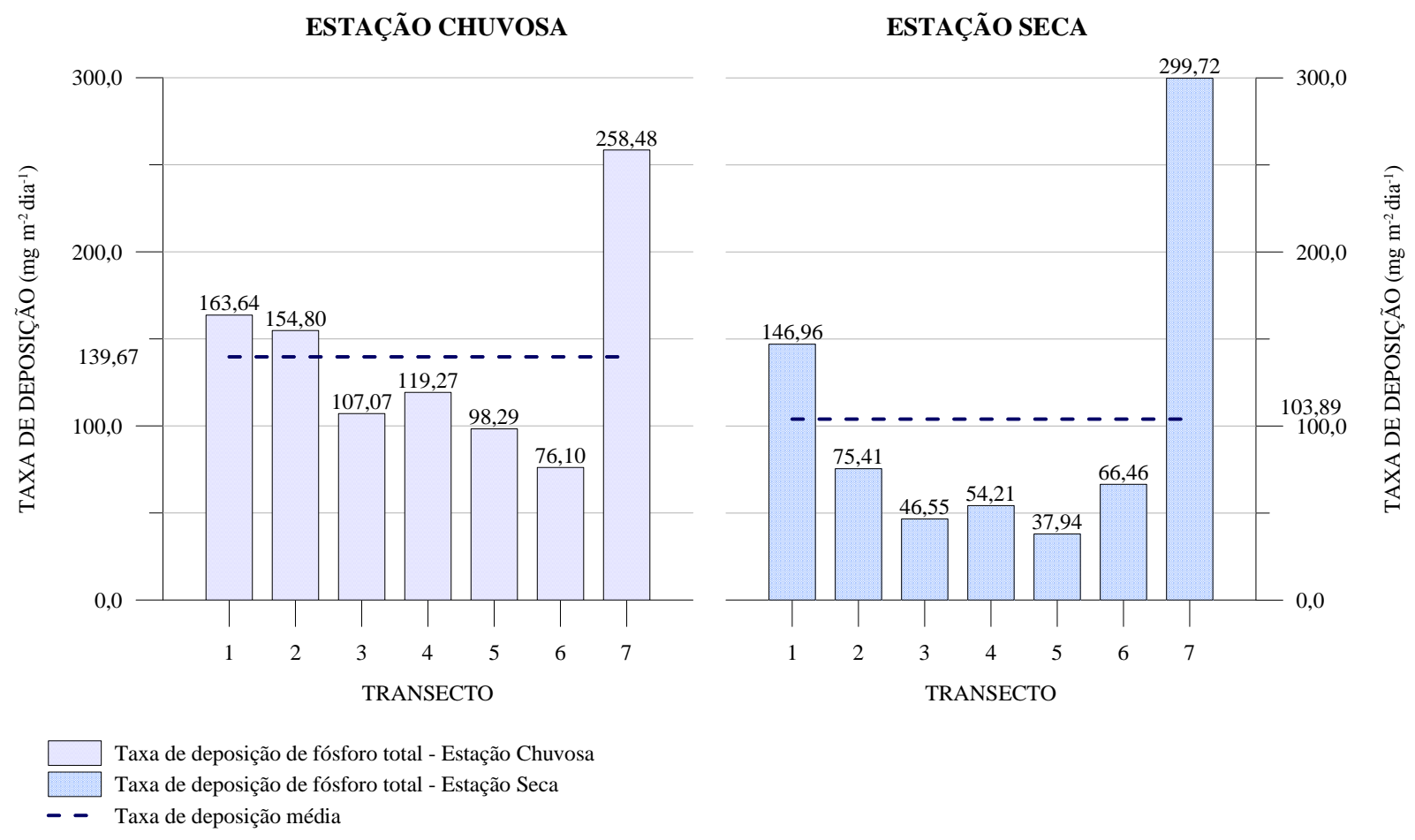

Figura 33. Taxa de deposição de fósforo total $\left(\mathrm{mg} \mathrm{m}^{-2} \operatorname{dia}^{-1}\right)$.

Essas taxas de deposição são inferiores às encontradas por Leite (2002) no Reservatório de Salto Grande, com 462,60 $\mathrm{mg} \mathrm{m}^{-2} \mathrm{dia}^{-1}$, no entanto são maiores que as taxas encontradas pelo mesmo autor junto à barragem daquele reservatório, cujas taxas atingiram $68,40 \mathrm{mg} \mathrm{m}^{-2} \mathrm{dia}^{-1}$.

As taxas encontradas neste trabalho são maiores inclusive que as taxas máximas de 79,70 $\mathrm{mg} \mathrm{m}^{-2}$ dia $^{-1}$ encontradas por Marquisá (1998) no Reservatório de Barra Bonita e que as taxas de $36,60 \mathrm{mg} \mathrm{m}^{-2}$ dia $^{-1}$ no Reservatório do Lobo.

Deve-se considerar que o ambiente estudado pelo primeiro autor recebe esgotos de grandes cidades localizadas à montante da área, a saber: Campinas, Sumaré e Americana. Fato que, segundo o próprio autor, pode influenciar significativamente nos resultados por ele encontrado. 


\section{$\checkmark$ Silicato reativo}

As taxas de deposição de silicato reativo, durante a Estação Chuvosa, pouco variaram, permanecendo em torno de $1,41 \pm 0,35 \mathrm{~g} \mathrm{~m}^{-2} \mathrm{dia}^{-1}$, como representando pela Figura 34. Já as taxas de deposição durante a Estação Seca também permaneceram em torno de $1,45 \pm 1,39 \mathrm{~g} \mathrm{~m}^{-2} \mathrm{dia}^{-1}$, contudo apresentaram variações mais expressivas, a citar o Transecto 4, cuja taxa de deposição foi 354,15\% menor que a taxa média da Estação.

Também pode-se observar que as taxas de deposição nos Transectos 1, 2 e 3 da Estação Seca foram, em média, 96,43\% maiores que a média da Estação, porém, as taxas de deposição observadas nos Transectos 4, 5, 6 e 7 foram, em média, 261,33\% menores que a média dessa Estação.

ESTAÇÃO CHUVOSA

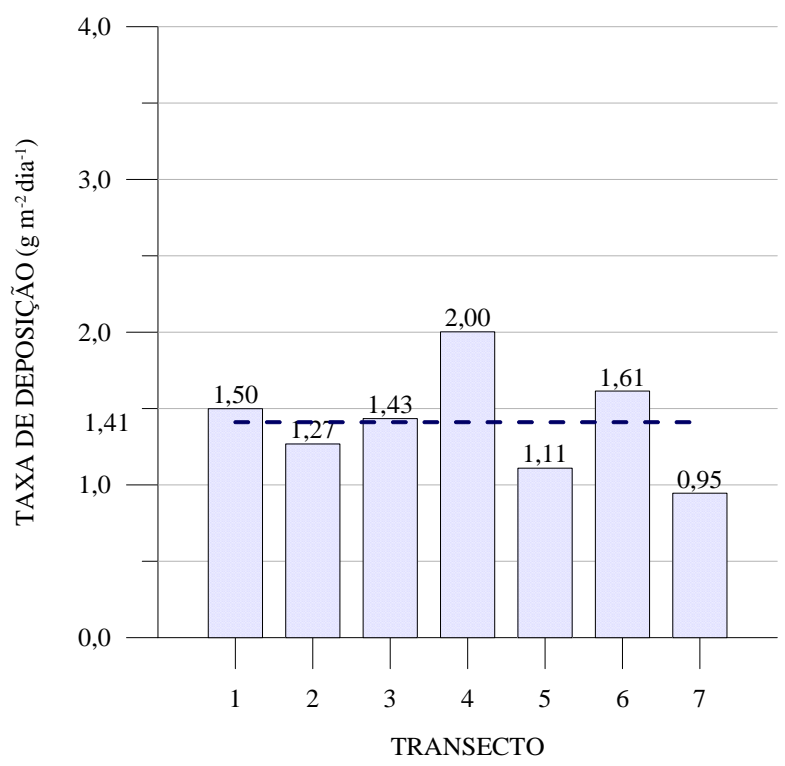

Taxa de deposição de silicato reativo - Estação Chuvosa

Taxa de deposição de silicato reativo - Estação Seca

- - Taxa de deposição média
ESTAÇÃO SECA

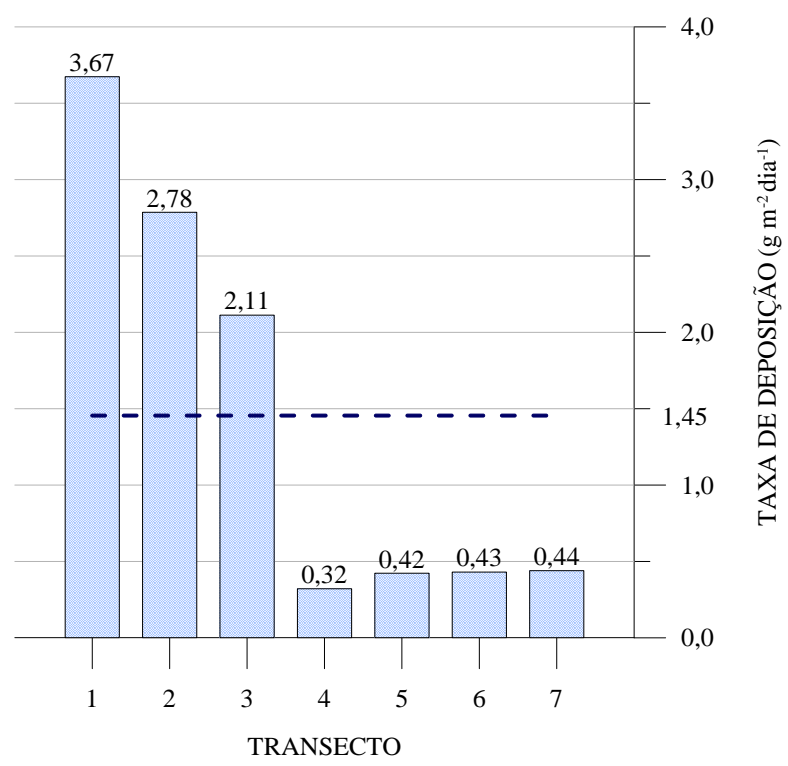

Figura 34. Taxa de deposição de silicato reativo $\left(\mathrm{g} \mathrm{m}^{-2} \mathrm{dia}^{-1}\right)$. 


\subsection{Medição de vazão}

A vazão de cada Transecto foi calculada utilizando-se o ADP, conforme metodologia descrita anteriormente. Nas Figuras seguintes estão representadas as células de velocidade observadas durante as medições, e nas Tabelas seguintes foram relacionados os dados característicos destas medições, que incluem o comprimento $(\mathrm{m})$, a área $\left(\mathrm{m}^{2}\right)$, a velocidade média da água $\left(\mathrm{m} \mathrm{s}^{-1}\right)$ e, por final, a vazão $\left(\mathrm{m}^{3} \mathrm{~s}^{-1}\right)$ do Transecto.

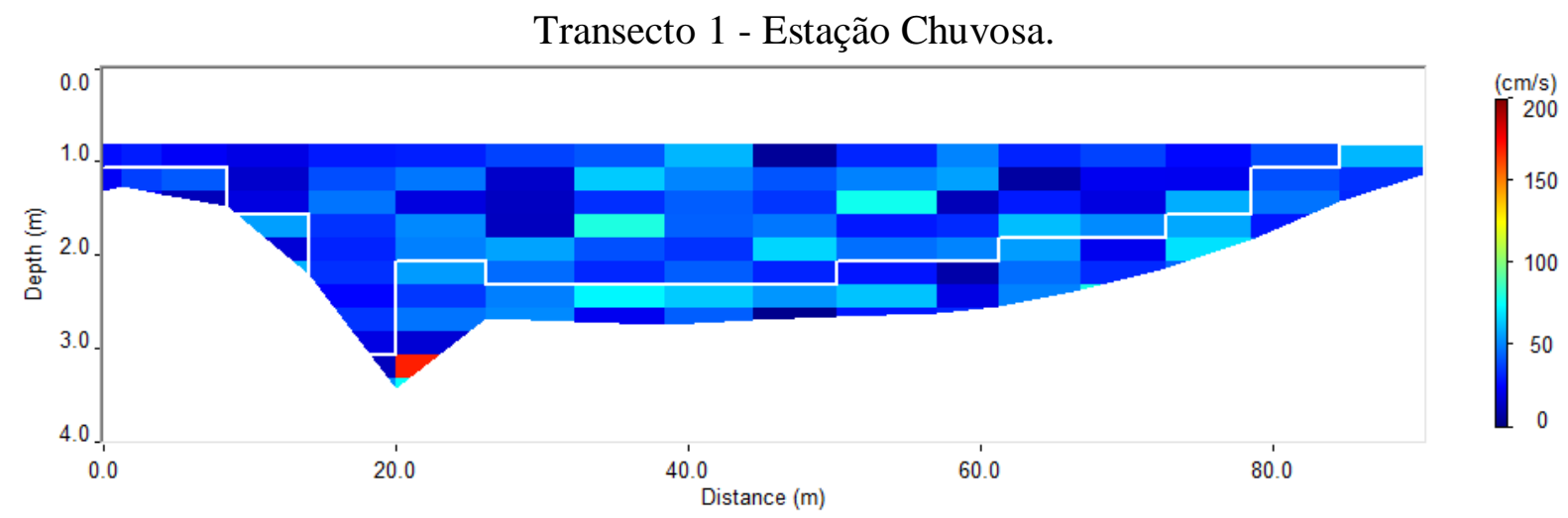

Transecto 1 - Estação Seca.

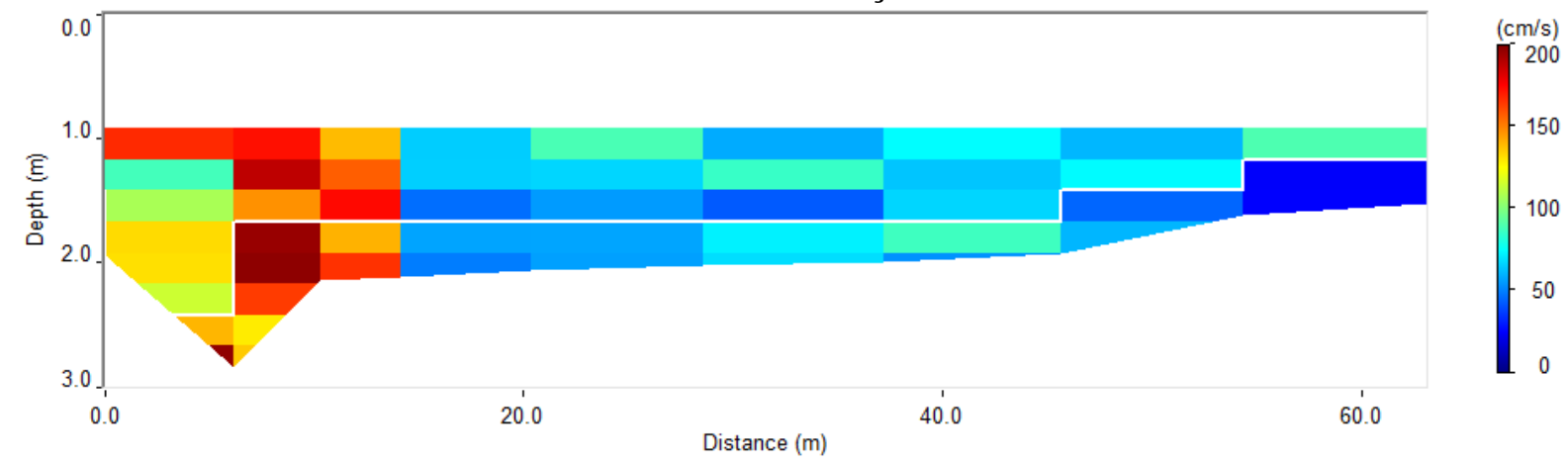

Figura 35. Gráficos da medição da vazão do Transecto 1, utilizando o ADP.

Tabela 10. Dados da medição da vazão do Transecto 1 .

\begin{tabular}{lcc}
\hline Parâmetro & Estação Chuvosa & Estação Seca \\
\hline Comprimento do transecto $(\mathrm{m})$ & 142,60 & 147,40 \\
Área $\left(\mathrm{m}^{2}\right)$ & 204,30 & 523,00 \\
Velocidade média $\left(\mathrm{m} \mathrm{s}^{-1}\right)$ & 0,33 & 0,55 \\
Vazão $\left(\mathrm{m}^{3} \mathrm{~s}^{-1}\right)$ & 67,42 & 285,73 \\
\hline
\end{tabular}


Transecto 2 - Estação Chuvosa

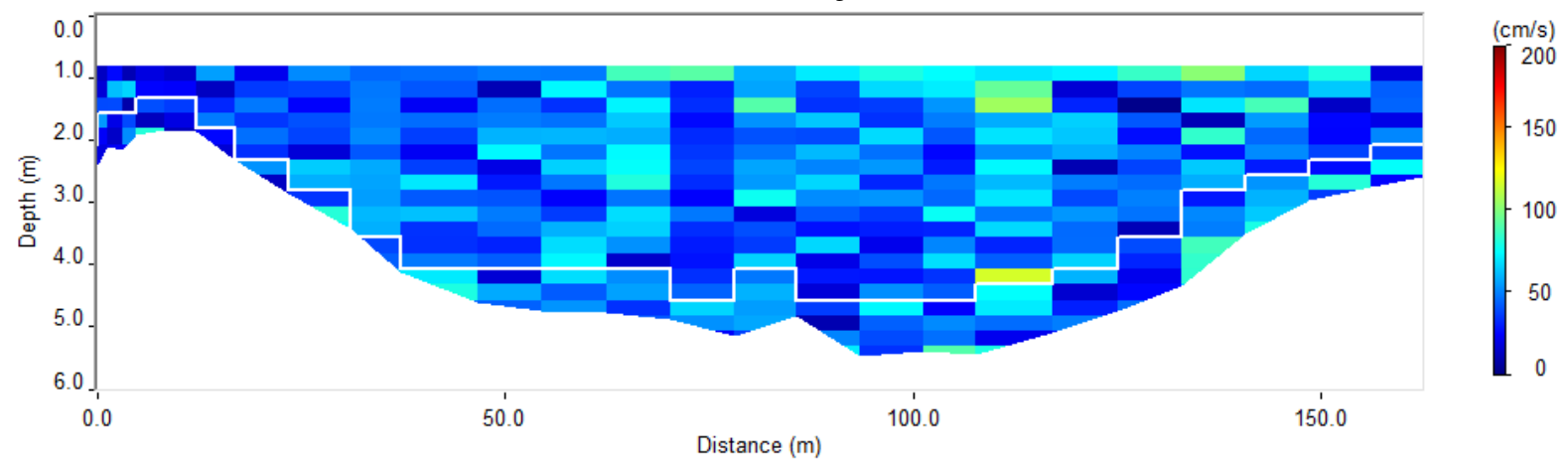

Transecto 2 - Estação Seca

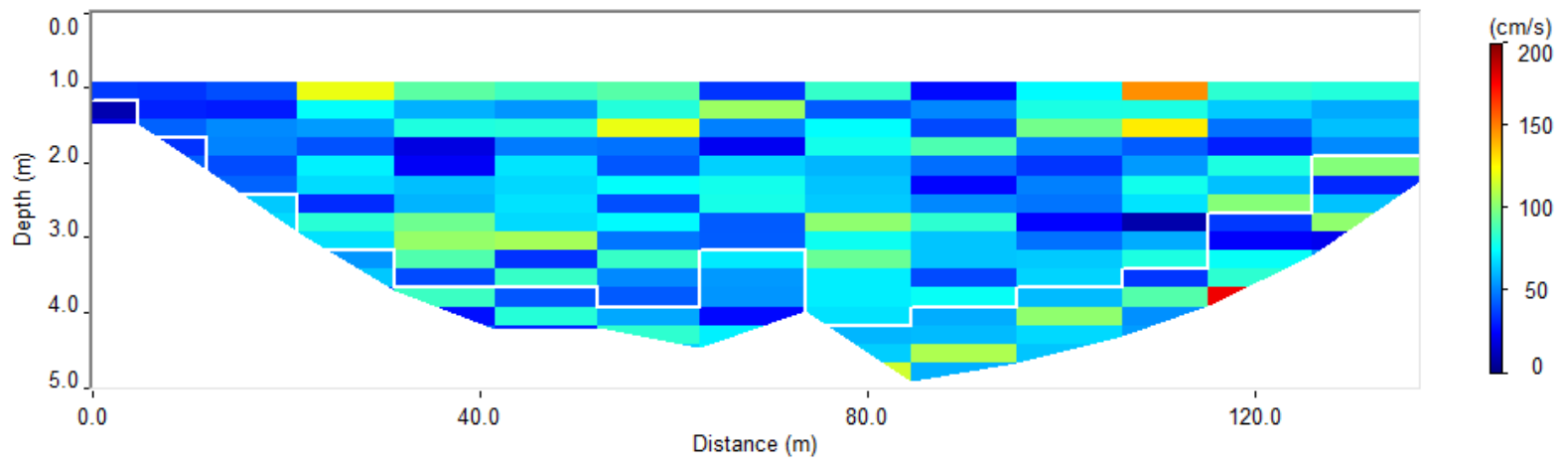

Figura 36. Gráficos da medição da vazão do Transecto 2, utilizando o ADP.

Tabela 11. Dados da medição da vazão do Transecto 2 .

\begin{tabular}{lcc}
\hline Parâmetro & Estação Chuvosa & Estação Seca \\
\hline Comprimento do transecto $(\mathrm{m})$ & 205,8 & 147,40 \\
Área $\left(\mathrm{m}^{2}\right)$ & 835,66 & 547,80 \\
Velocidade média $\left(\mathrm{m} \mathrm{s}^{-1}\right)$ & 0,34 & 0,54 \\
Vazão $\left(\mathrm{m}^{3} \mathrm{~s}^{-1}\right)$ & 284,12 & 295,35 \\
\hline
\end{tabular}


Transecto 3 - Estação Chuvosa

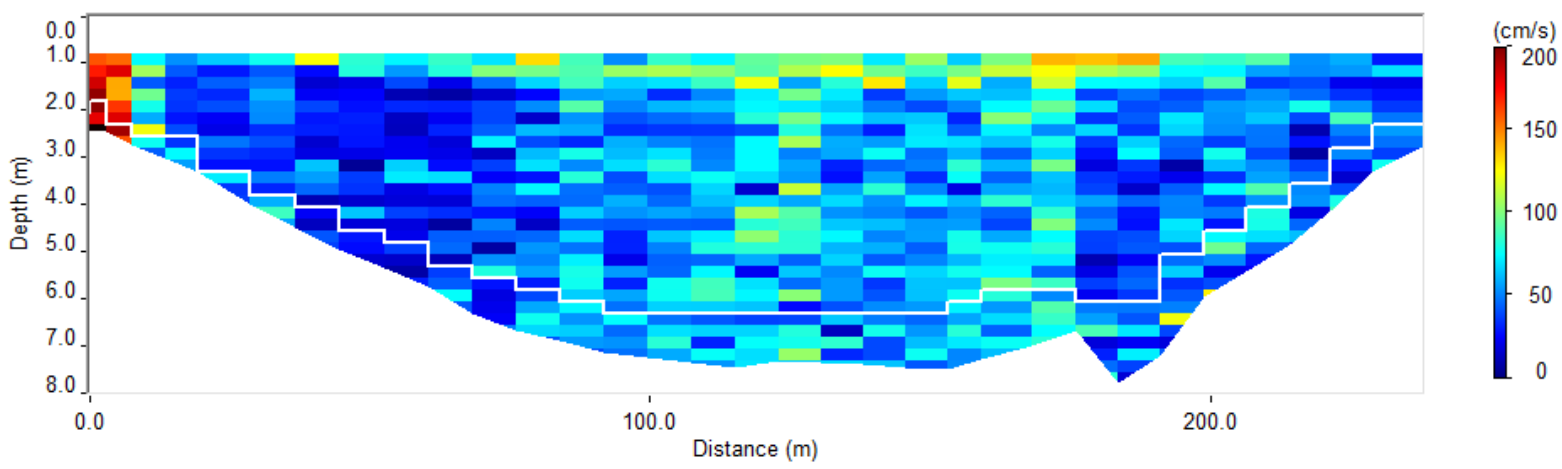

Transecto 3 - Estação Seca

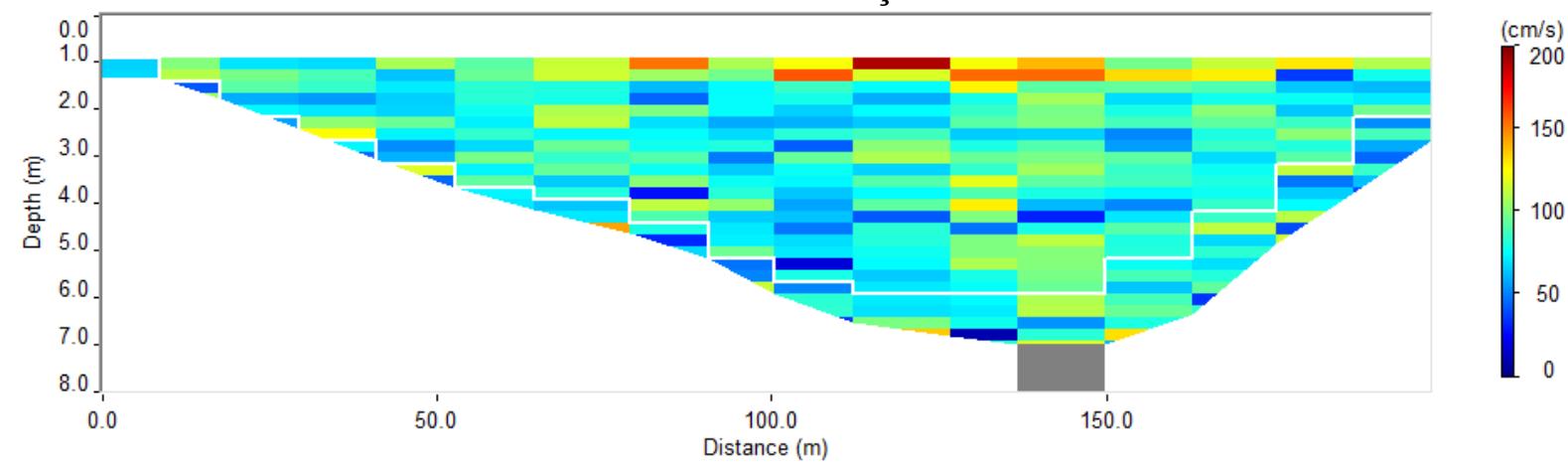

Figura 37. Gráficos da medição da vazão do Transecto 3, utilizando o ADP.

Tabela 12. Dados da medição da vazão do Transecto 3.

\begin{tabular}{lcc}
\hline Parâmetro & Estação Chuvosa & Estação Seca \\
\hline Comprimento do transecto $(\mathrm{m})$ & 318,40 & 221,60 \\
Área $\left(\mathrm{m}^{2}\right)$ & 1575,90 & 983,30 \\
Velocidade média $\left(\mathrm{m} \mathrm{s}^{-1}\right)$ & 0,36 & 0,74 \\
Vazão $\left(\mathrm{m}^{3} \mathrm{~s}^{-1}\right)$ & 574,20 & 726,47 \\
\hline
\end{tabular}


Transecto 4 - Estação Chuvosa

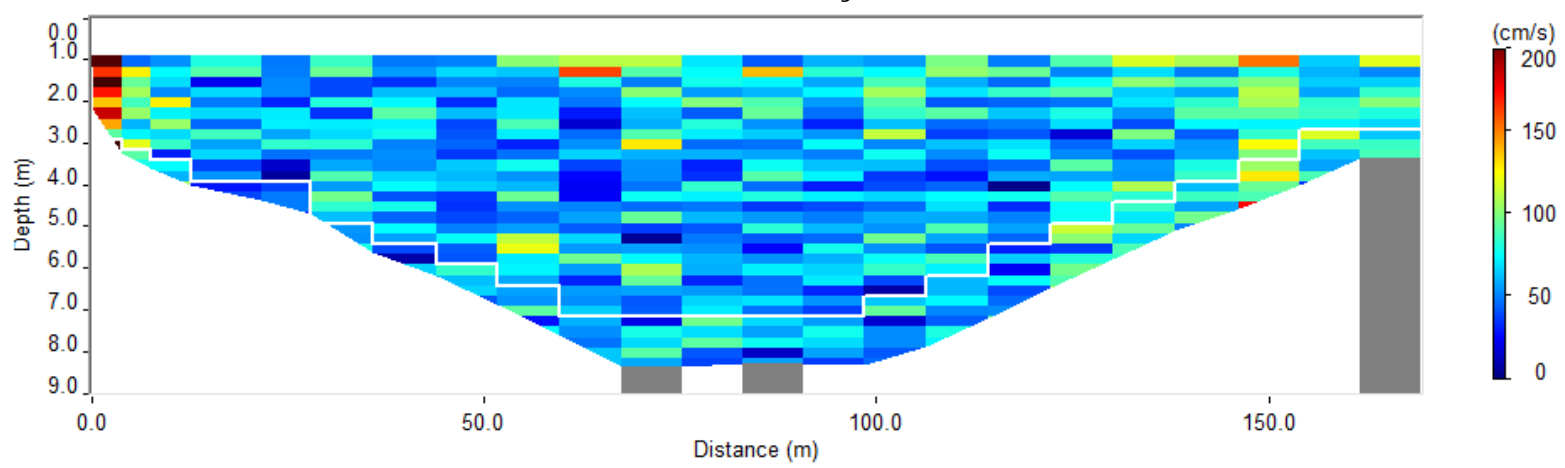

Transecto 4 - Estação Seca

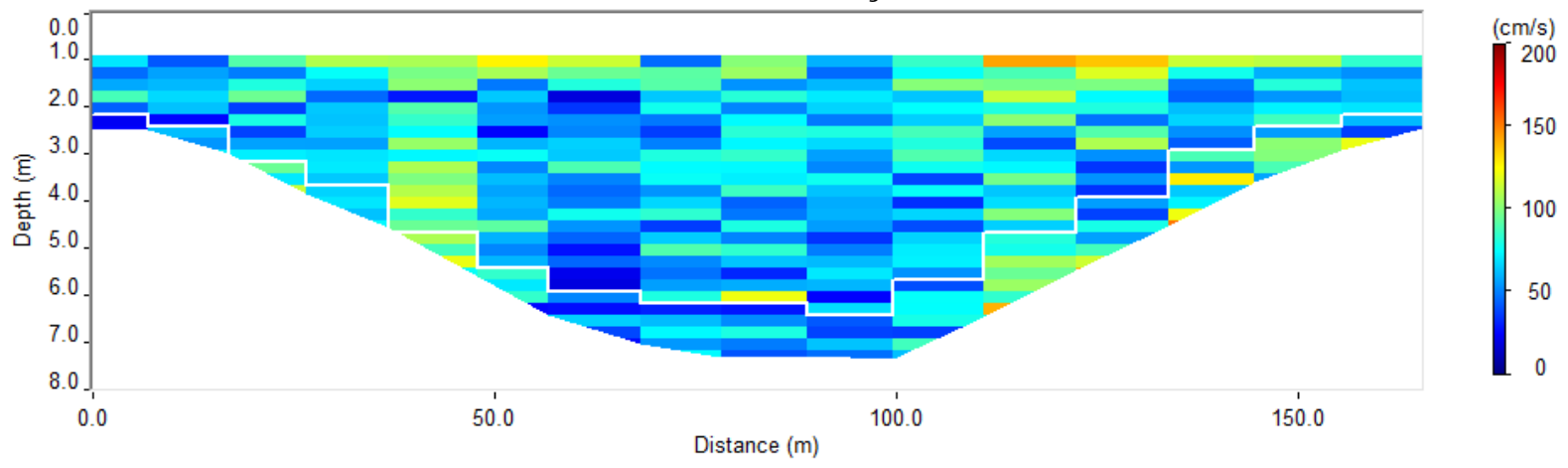

Figura 38. Gráficos da medição da vazão do Transecto 4, utilizando o ADP.

Tabela 13. Dados da medição da vazão do Transecto 4.

\begin{tabular}{lcc}
\hline Parâmetro & Estação Chuvosa & Estação Seca \\
\hline Comprimento do transecto $(\mathrm{m})$ & 263,40 & 218,00 \\
Área $\left(\mathrm{m}^{2}\right)$ & 1283,80 & 969,40 \\
Velocidade média $\left(\mathrm{m} \mathrm{s}^{-1}\right)$ & 0,45 & 0,55 \\
Vazão $\left(\mathrm{m}^{3} \mathrm{~s}^{-1}\right)$ & 582,39 & 531,51 \\
\hline
\end{tabular}




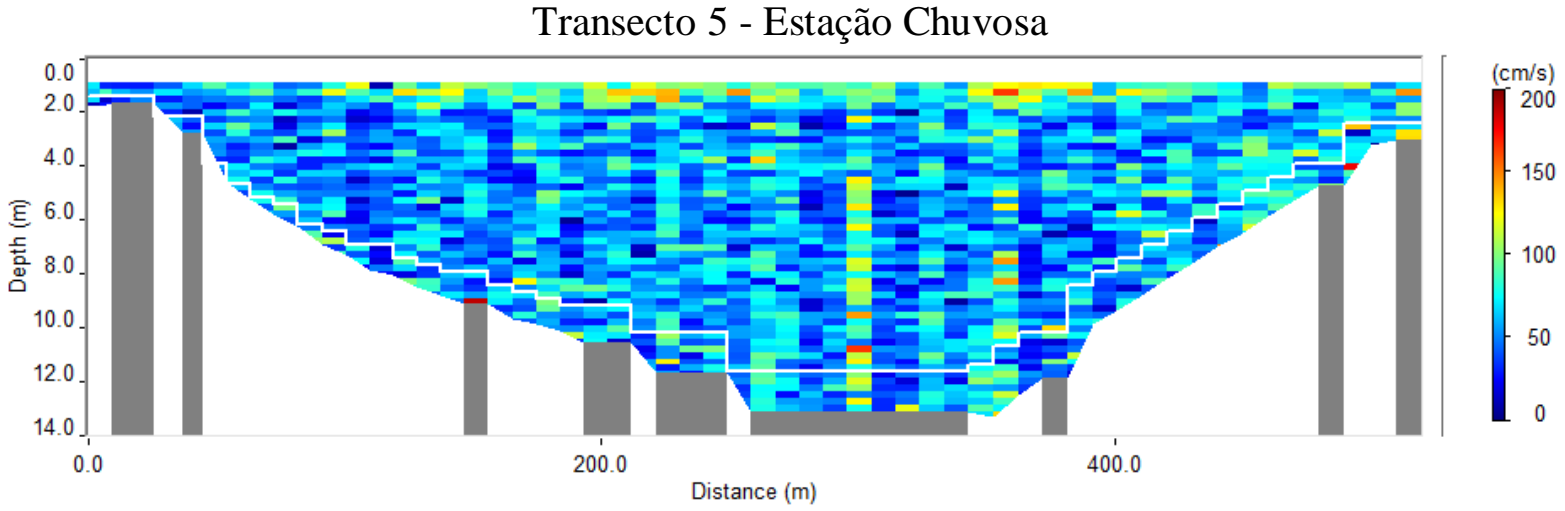

Transecto 5 - Estação Seca

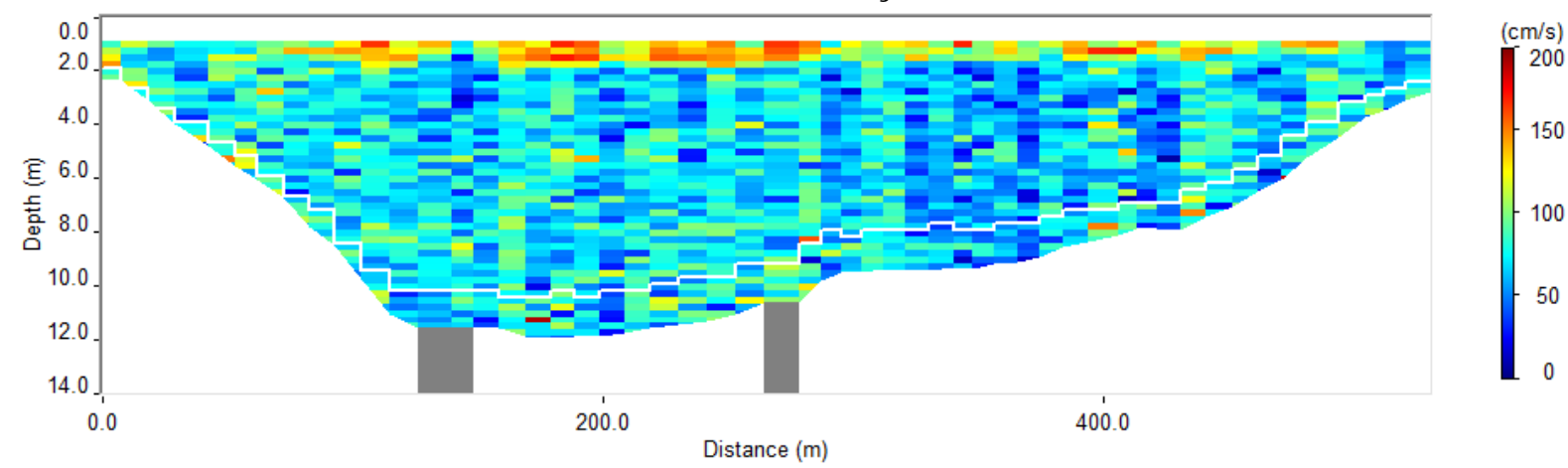

Figura 39. Gráficos da medição da vazão do Transecto 5, utilizando o ADP.

Tabela 14. Dados da medição da vazão do Transecto 5 .

\begin{tabular}{lcc}
\hline Parâmetro & Estação Chuvosa & Estação Seca \\
\hline Comprimento do transecto $(\mathrm{m})$ & 607,80 & 566,80 \\
Área $\left(\mathrm{m}^{2}\right)$ & 4883,50 & 4634,60 \\
Velocidade média $\left(\mathrm{m} \mathrm{s}^{-1}\right)$ & 0,48 & 0,61 \\
Vazão $\left(\mathrm{m}^{3} \mathrm{~s}^{-1}\right)$ & 2343,90 & 2817,90 \\
\hline
\end{tabular}


Transecto 6 - Estação Chuvosa

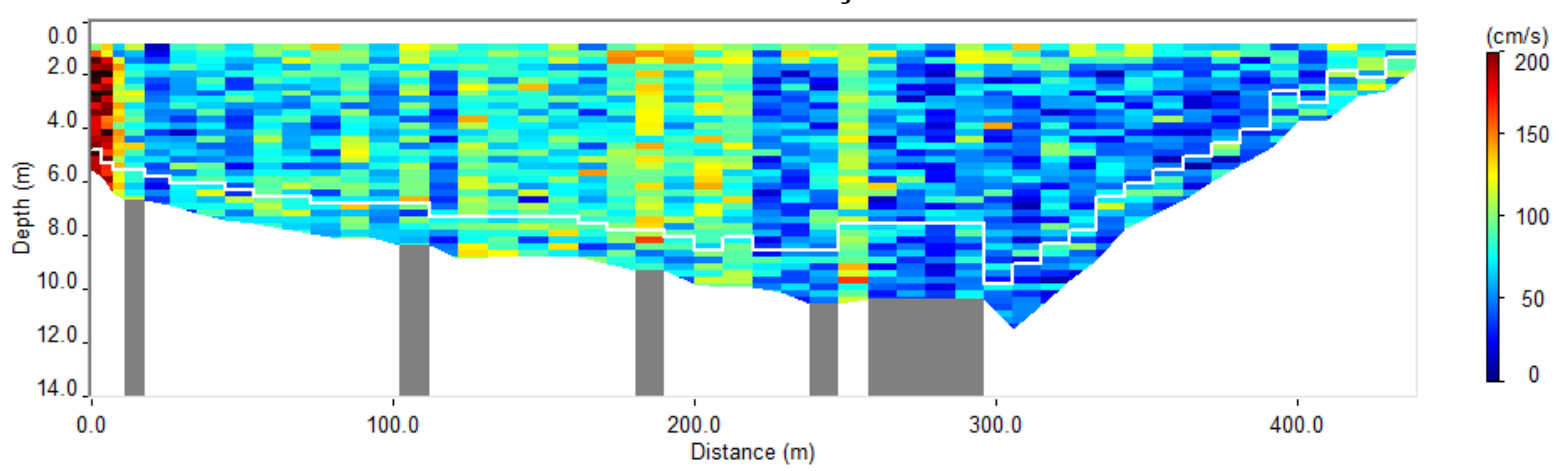

Transecto 6 - Estação Seca

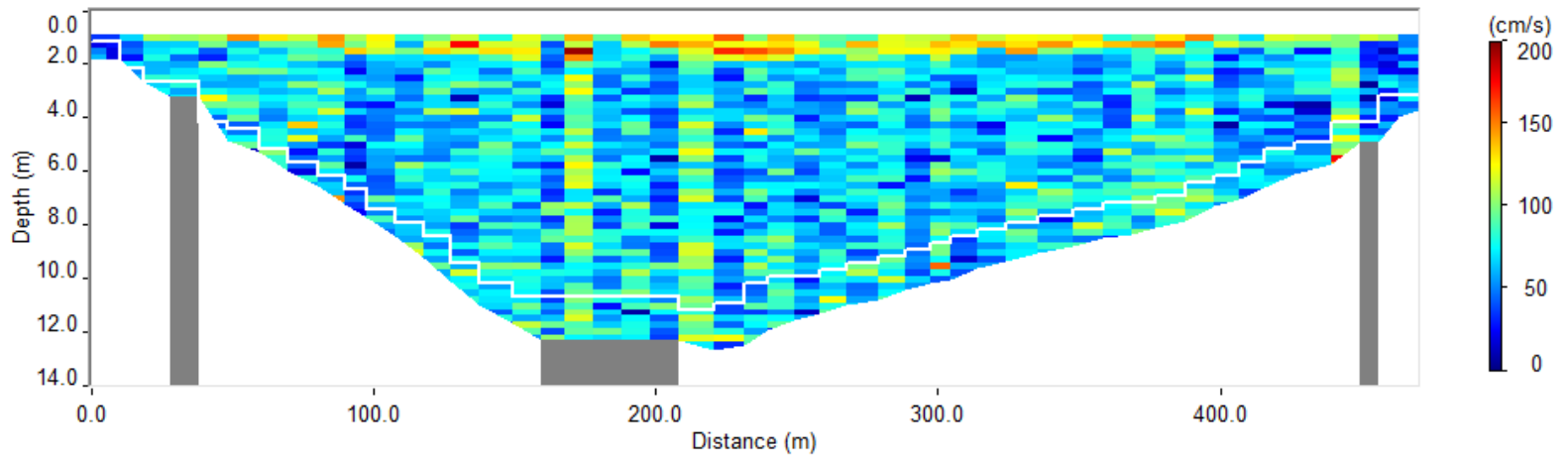

Figura 40. Gráficos da medição da vazão do Transecto 6, utilizando o ADP.

Tabela 15. Dados da medição da vazão do Transecto 6.

\begin{tabular}{lcc}
\hline Parâmetro & Estação Chuvosa & Estação Seca \\
\hline Comprimento do transecto $(\mathrm{m})$ & 792,10 & 555,0 \\
Área $\left(\mathrm{m}^{2}\right)$ & 5007,6 & 4362,80 \\
Velocidade média $\left(\mathrm{m} \mathrm{s}^{-1}\right)$ & 0,40 & 0,56 \\
Vazão $\left(\mathrm{m}^{3} \mathrm{~s}^{-1}\right)$ & 1997,70 & 2441,50 \\
\hline
\end{tabular}


Transecto 7 - Estação Chuvosa

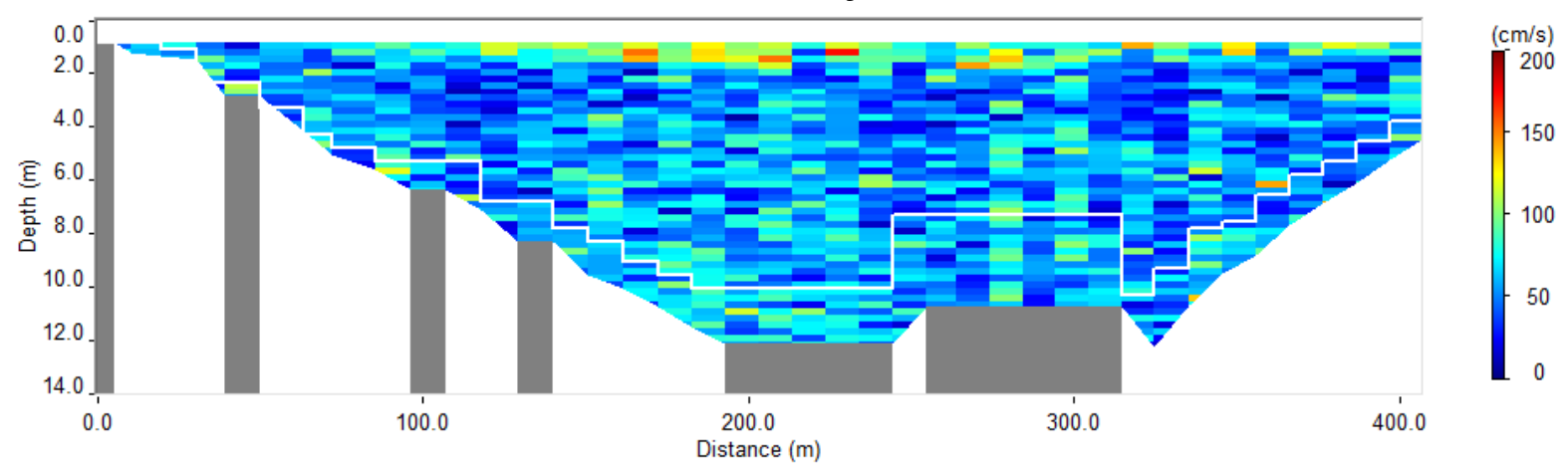

Transecto 7 - Estação Seca

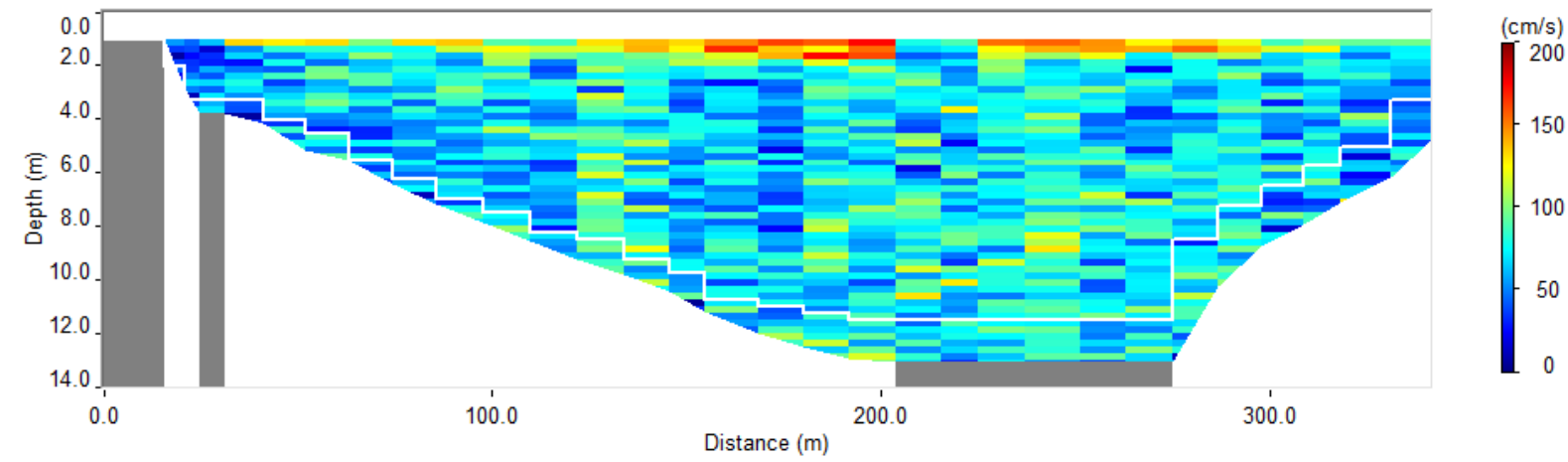

Figura 41. Gráfico da medição da vazão do Transecto 7, utilizando o ADP.

Tabela 16. Dados da medição da vazão do Transecto 7.

\begin{tabular}{lcc}
\hline Parâmetro & Estação Chuvosa & Estação Seca \\
\hline Comprimento do transecto $(\mathrm{m})$ & 500,70 & 387,80 \\
Área $\left(\mathrm{m}^{2}\right)$ & 3732,30 & 3304,20 \\
Velocidade média $\left(\mathrm{m} \mathrm{s}^{-1}\right)$ & 0,44 & 0,59 \\
Vazão $\left(\mathrm{m}^{3} \mathrm{~s}^{-1}\right)$ & 1629,60 & 1963,50 \\
\hline
\end{tabular}


Segundo os dados obtidos a partir da medição de vazão utilizando o ADP, foi possível notar, conforme representado na Figura 42, que as áreas dos Transectos durante a Estação Chuvosa foram superiores às áreas dos Transectos na Estação Seca, porém a velocidade média da água foi menor, diferentemente do se esperaria para um período chuvoso, no qual, devido maior volume de águas, provocaria maior velocidade de fluxo.
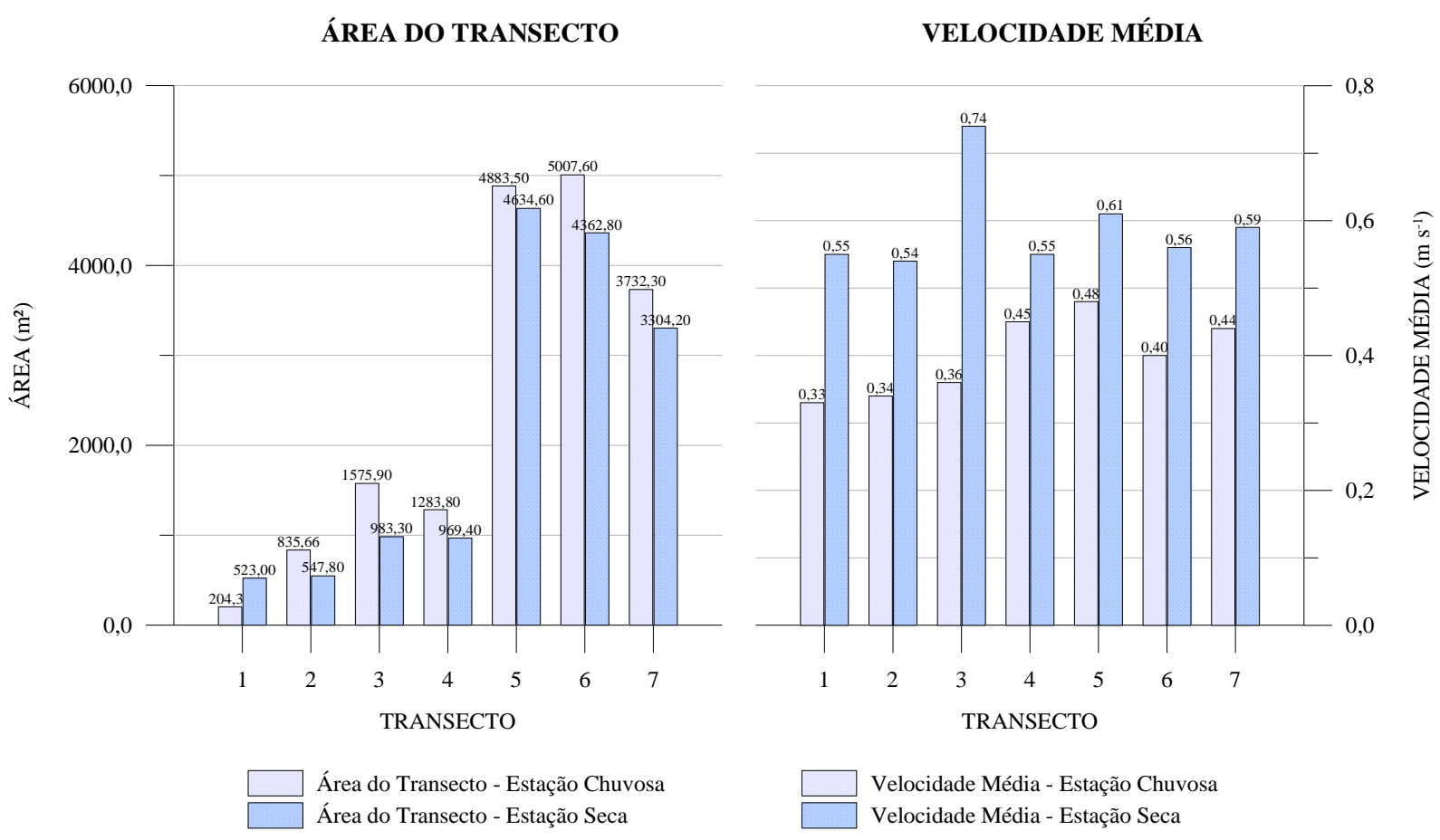

Figura 42. Variação das áreas dos transectos e das velocidades médias da água.

Isto é explicado pelo fato que, durante a Estação Chuvosa, os principais reservatórios que compõem a cascata do Rio Tietê, à montante da UHE de Três Irmãos, que inclui as UHEs de Barra Bonita, Bariri, Ibitinga, Promissão e Nova Avanhandava, não estão fazendo reservação de água, mas, no entanto, a UHE de Três Irmãos promove a reservação no período de chuva, para posteriormente poder suprir as demandas durante os meses de estiagem.

Por isto, durante a Estação Chuvosa foi observado que as áreas dos Transectos foram superiores às áreas dos Transectos durante a Estação Seca, e consequentemente o volume em relação a um nível referencial. Mas como o reservatório está promovendo a reservação de água, apesar de haver fluxo, a velocidade é menor do que o esperado para o período. 


\subsection{Exportação de sólidos e nutrientes}

Pensando apenas no conceito da concentração, que relaciona a quantidade de certo elemento com o volume no qual este elemento está diluído, em nenhum momento tem-se a informação da quantidade total do elemento presente no ambiente, em função do tempo analisado e, quando da análise de corpo d'água em movimento, não se tem a informação da quantidade que está sendo transportado.

Ao analisar a concentração de determinado elemento sem atentar para a real quantidade presente no ambiente pode-se equivocadamente majorar ou minorar seus efeitos.

Por isto, se o intuito for conhecer a quantidade total de material que está sendo transportado, ou seja, a carga ou o fluxo deste elemento, é necessário conhecer, além da concentração do elemento, a vazão daquele corpo d'água.

Cullen et al. $^{3}$ (1988 apud HENRY, 1992) já mencionava que os estudos envolvendo as cargas de nutrientes deveriam estar mais associados aos estudos hidrológicos e que por isto as informações provenientes de estudos limitados às estações chuvosa e aos períodos de estiagem teriam valores maiores do que aqueles observados em coletas diárias.

Contudo, Stevens e $\operatorname{Smith}^{4}$ (1978 apud HENRY, 1992) ressaltavam a importância da precisão na medição da vazão, considerando até ser mais importante do que a própria concentração em estudos de determinação de cargas.

Neste sentido esse estudo analisou as taxas de exportação de sólidos e nutrientes na sub-bacia, cujos resultados serão detalhados a seguir.

Em se tratando da qualidade da medição da vazão do corpo d'água para fins de determinação das taxas de exportação, conforme já citado, foi utilizada a mais avançada tecnologia disponível para medição, que baseia-se no efeito doopler, sendo que por esta metodologia é dispensado qualquer cálculo em função do comprimento ou da profundidade do transecto, pois a medição com o ADP é baseada na integral dos diversos valores calculados na horizontal e também na vertical, muito mais confiáveis que as medições de vazão utilizando, por exemplo, molinete hidrométrico.

\footnotetext{
${ }^{3}$ CULLEN, P.; FARMER, N.; O’LOUGHLIN, E. Estimating nonpoint sources of phosphorus to lakes. Verh. Internat. Verein. Limnol, 1988. p. 588 - 593.

${ }^{4}$ STEVENS, R. J. e SMITH, R. V. A comparison of discrete and intensive sampling for measuring the loads of nitrogen and phosphorus in the River Main, Country Antrim. Water Res., 1978. p. 823 - 830.
} 


\section{$\checkmark$ Sólidos suspensos}

Na Figura 43 está representada a taxa de exportação de sólidos suspensos, orgânicos e inorgânicos nas Estações Chuvosa e Seca. É notável que as taxas de exportação na Estação Chuvosa, de 2328,44 $\pm 1506,24$ ton dia $^{-1}$, são superiores que as taxas de exportação na Estação Seca, de 725,96 \pm 203,64 ton dia $^{-1}$, em média 220,74\% maiores, prevalecendo a fração inorgânica dos sedimentos.

Nos Transectos 5, 6 e 7, da Estação Chuvosa, foram observadas as maiores taxas de exportação, sendo de 4381,11, 4128,04 e 2948,09 ton dia ${ }^{-1}$, respectivamente, sendo esta última taxa relacionada á exportação total da sub-bacia para o reservatório, durante a Estação.

Mesmo tendo as maiores velocidades médias, as taxas de exportação durante a Estação Seca foram de 725,96 ton dia $^{-1}$, em média, sendo a exportação para o reservatório de 741,56 ton $\mathrm{dia}^{-1}$.

Nestas circunstâncias, considerando a média das taxas de exportação para o reservatório entre as Estações Chuvosa e Seca pode-se concluir que a sub-bacia do Ribeirão das Cruzes contribui com 1844,83 toneladas diárias de sólidos orgânicos e inorgânicos, totalizando cerca de 673363 toneladas anuais. Henry e Maricato (1996) verificaram que a contribuição do Rio Paranapanema, em 1992, foi de 129300 toneladas para o Reservatório de Jurumirim. Leite (1998) verificou que o Rio Atibaia, em 1997, contribui com 104058 toneladas anuais para o Reservatório de Salto Grande.

\section{$\checkmark$ Nitrito}

As taxas de exportação de nitrito foram expressas graficamente conforme Figura 44, e segundo a qual é possível notar que as taxas de exportação durante a Estação Chuvosa, cujos valores médios foram 516,67 $\pm 424,41 \mathrm{~kg} \mathrm{dia}^{-1}$, foram 123,43\% maiores, em média, que as taxas da Estação Seca, cujos valores médios foram de 231,24 $\pm 205,34 \mathrm{~kg} \mathrm{dia}^{-1}$.

Em ambas Estações é possível notar tendência crescente das taxas de exportação nos Transectos 1, 2, 3, 4 e 5, sendo que este último alcançou a maior taxa de cada Estação, com 1285,55 e 513,59 $\mathrm{kg} \mathrm{dia}^{-1}$, respectivamente. Já nos Transectos 6 e 7 subsequentes as taxas sempre foram decrescentes.

Especificamente em relação ao Transecto 7, que representa a exportação para o Reservatório de Três Irmãos, as taxas foram de 478,29 e 321,93 $\mathrm{kg}^{\text {dia }}{ }^{-1}$ nas Estações Chuvosa e Seca, respectivamente. 
ESTAÇÃO CHUVOSA

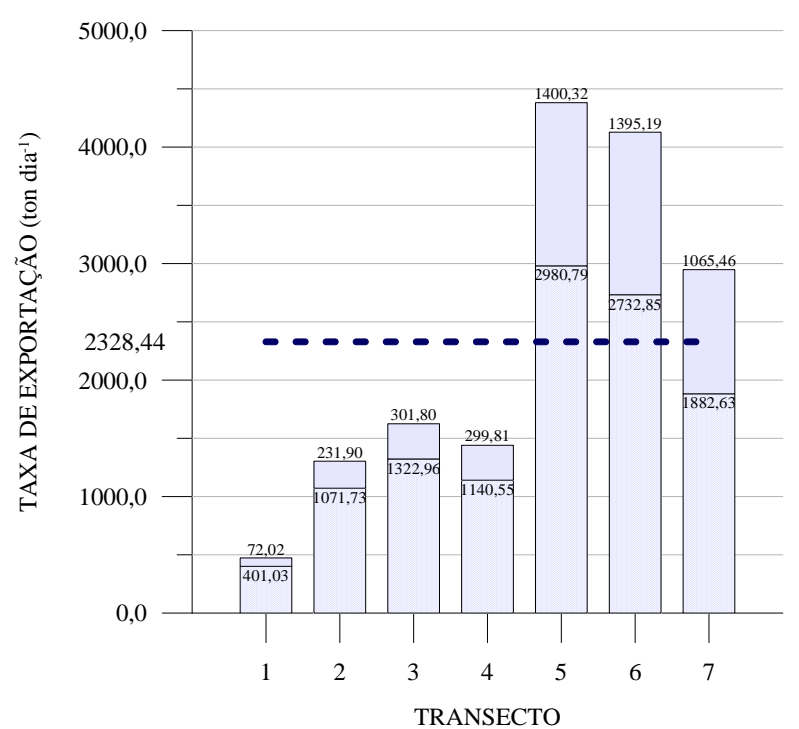

ESTAÇÃO SECA

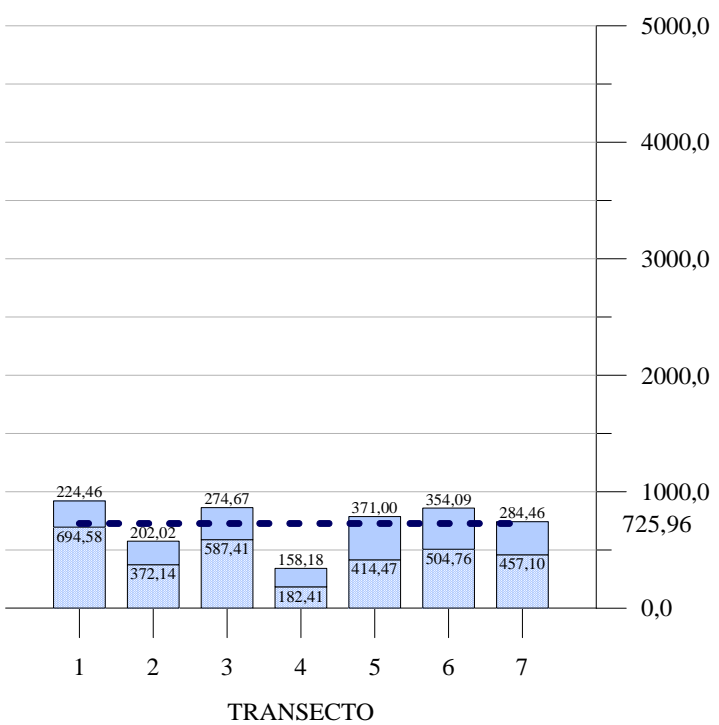

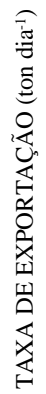

Taxa de exportação de sólidos suspensos inorgânicos - Estação Chuvosa Taxa de exportação de sólidos suspensos orgânicos - Estação Chuvosa Taxa de exportação de sólidos suspensos inorgânicos - Estação Seca Taxa de exportação de sólidos suspensos orgânicos - Estação Seca

- Taxa de exportação média

Figura 43. Taxa de exportação de sólidos suspensos (ton $\left.\operatorname{dia}^{-1}\right)$.
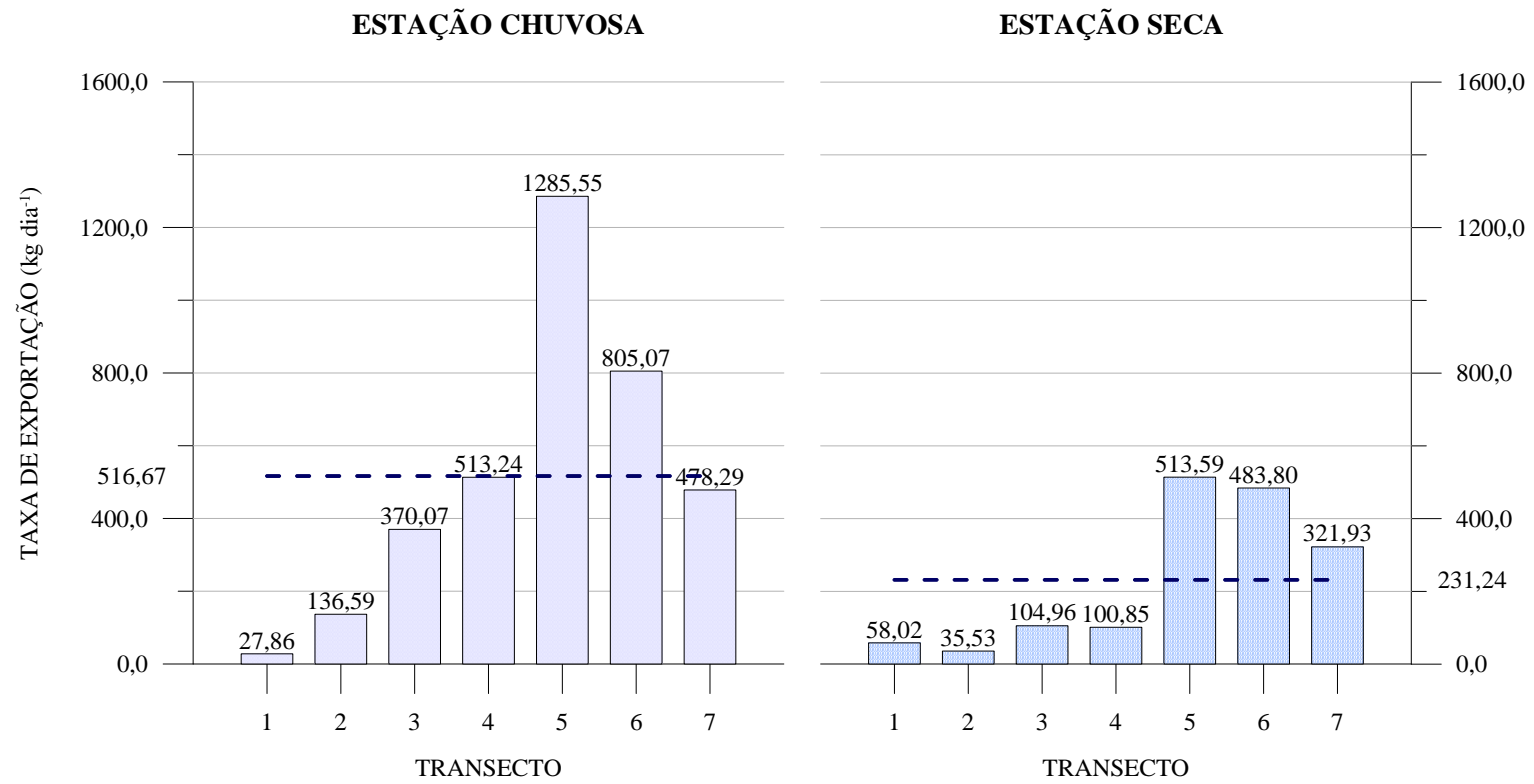

Taxa de exportação de nitrito - Estação Chuvosa

Taxa de exportação de nitrito - Estação Seca

- Taxa de exportação média

Figura 44. Taxa de exportação de nitrito $\left(\mathrm{kg} \mathrm{dia}^{-1}\right)$. 
$\checkmark$ Nitrato

Quanto as taxas de exportação de nitrato, conforme representado pela Figura 45, foi observado, em ambas Estações, tendência crescente nos Transectos 1, 2 e 3, e tendência decrescente nos Transectos 5, 6 e 7. As taxas de exportação da Estação Chuvosa, de $76,75 \pm 58,78$ ton $\mathrm{dia}^{-1}$, foram $20,18 \%$ inferiores às taxas da Estação Seca, que foram de $92,24 \pm 88,41$ ton $\mathrm{dia}^{-1}$.

Também foi comum o fato que em ambas as Estações as taxas dos Transectos 1, 2 e 3 foram muito inferiores à média da Estação, no entanto as taxas dos Transectos 5, 6 e 7 foram muito superiores.

A exportação média de nitrato para o Reservatório de Três Irmãos foi de 235,53 ton $\mathrm{dia}^{-1}$.

\section{$\checkmark$ Nitrogênio amoniacal}

Foi observado um comportamento praticamente crescente da taxa de exportação de nitrogênio amoniacal ao longo dos Transectos, nas diferentes Estações, conforme representado pela Figura 46.

Especificamente na Estação Chuvosa a taxa de exportação atingiu valores de 65,89 $\pm 52,69$ ton dia $^{-1}$, cerca de 141,93\% inferior, em média, do que na Estação Seca, quando os valores foram de $159,41 \pm 148,84$ ton $\mathrm{dia}^{-1}$.

Apenas o Transecto 6 da Estação Chuvosa e o Transecto 4 da Estação Seca não acompanharam a tendência observada. É se considerar a taxa de exportação do Transecto 5 da Estação Seca, pois com 447,74 ton dia $^{-1}$ foi $180,87 \%$ maior que a média da Estação.

Neste caso, a taxa de exportação para o Reservatório foi de 187,04 ton dia ${ }^{-1}$. 
ESTAÇÃO CHUVOSA

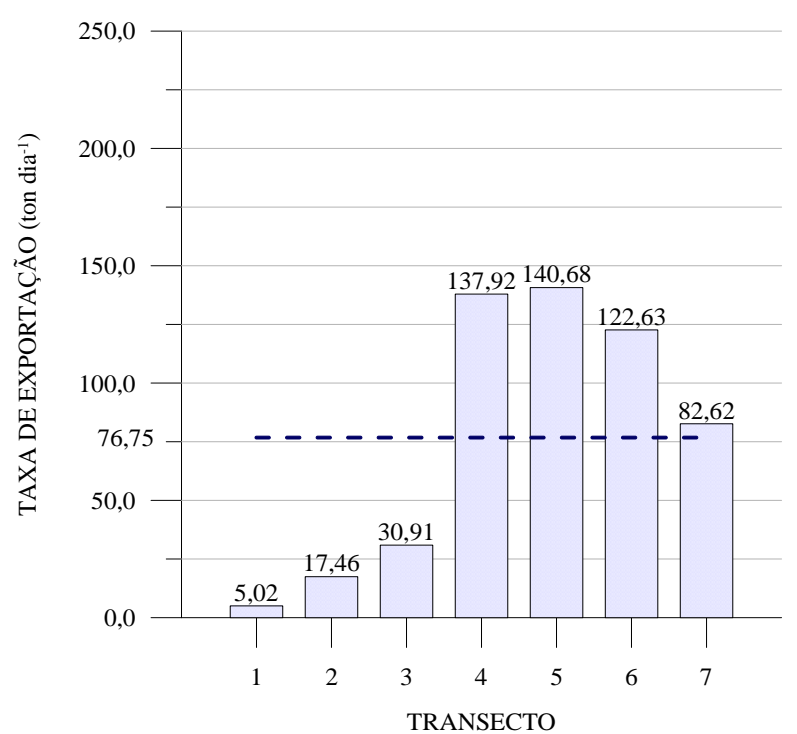

Taxa de exportação de nitrato - Estação Chuvosa

Taxa de exportação de nitrato - Estação Seca

- - Taxa de exportação média
ESTAÇÃO SECA

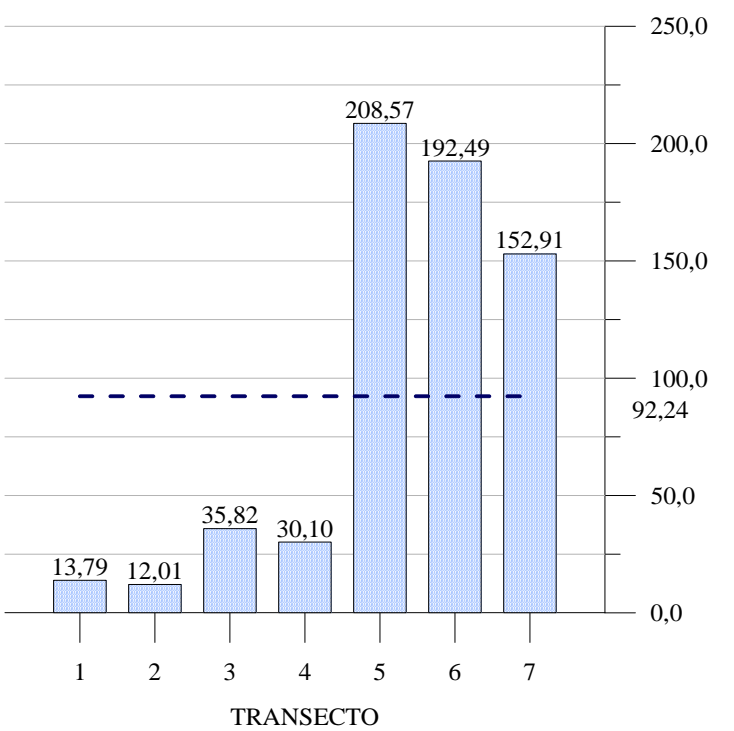

Figura 45. Taxa de exportação de nitrato (ton dia ${ }^{-1}$ ).

ESTAÇÃO CHUVOSA

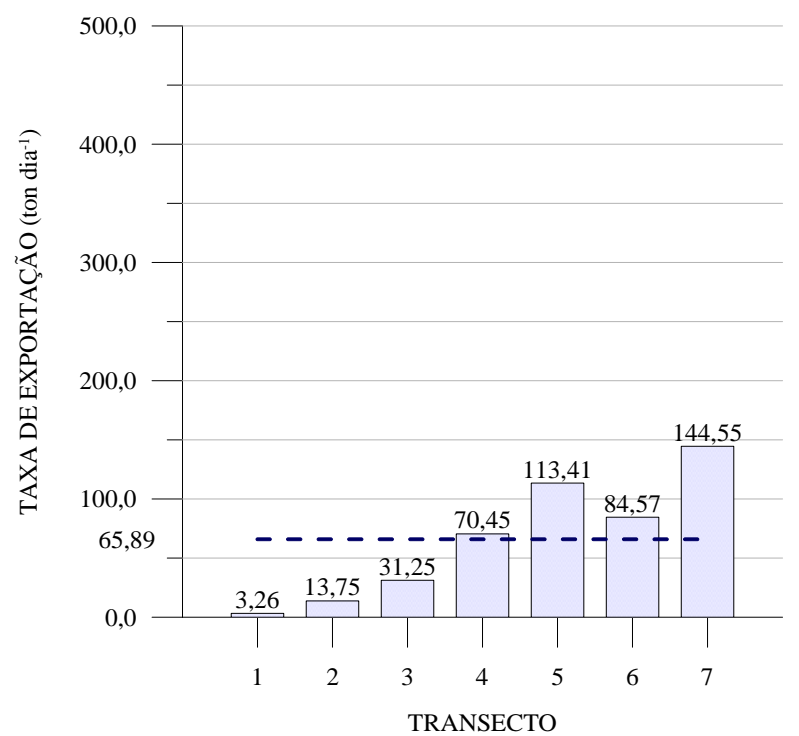

Taxa de exportação de nitrogênio amoniacal - Estação Chuvosa Taxa de exportação de nitrogênio amoniacal - Estação Seca

- Taxa de exportação média
ESTAÇÃO SECA

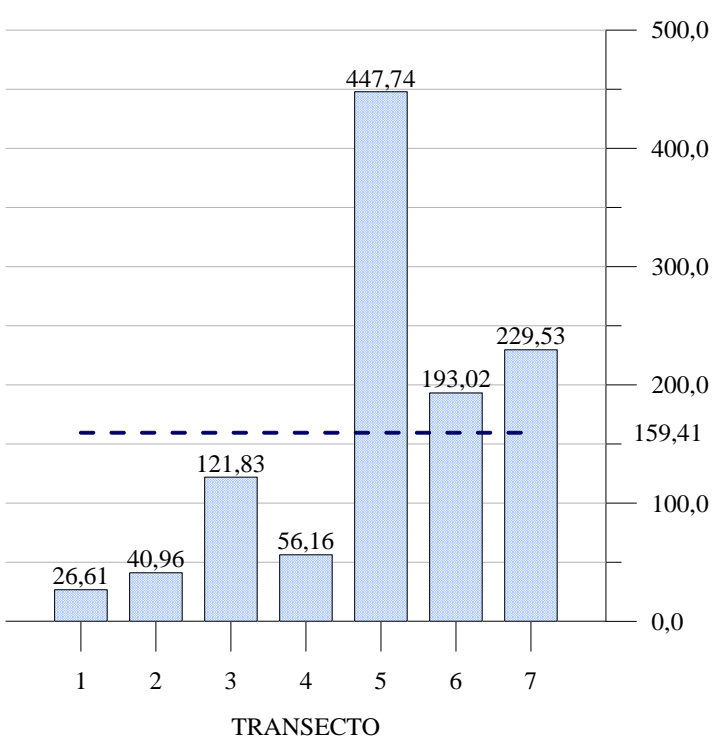

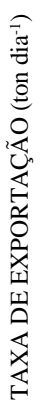

Figura 46. Taxa de exportação de nitrogênio amoniacal (ton dia ${ }^{-1}$ ). 


\section{$\checkmark$ Nitrogênio total Kjeldahl}

Foi observado que a taxa de exportação de nitrogênio total Kjeldahl, conforme representado pela Figura 47, acompanha a tendência crescente ao longo dos Transectos já observada anteriormente para nitrogênio amoniacal. No entanto, os valores em si se mostraram mais sensíveis às variações, por exemplo, nos Transectos 5 e 6 da Estação Chuvosa, cujos valores foram cerca de 2 e 3 vezes maior que a média da Estação, respectivamente.

As taxas de exportação de nitrogênio total Kjeldahl observadas durante a Estação Chuvosa foram de 121,41 $\pm 126,95$ ton dia $^{-1}$, ou seja, 146,96\% inferiores às taxas observadas durante a Estação Seca, com 299,84 $\pm 247,91$ ton dia $^{-1}$. A taxa de exportação para o Reservatório, observada no Transecto 7 , foi de 379,82 ton dia $^{-1}$, em média.

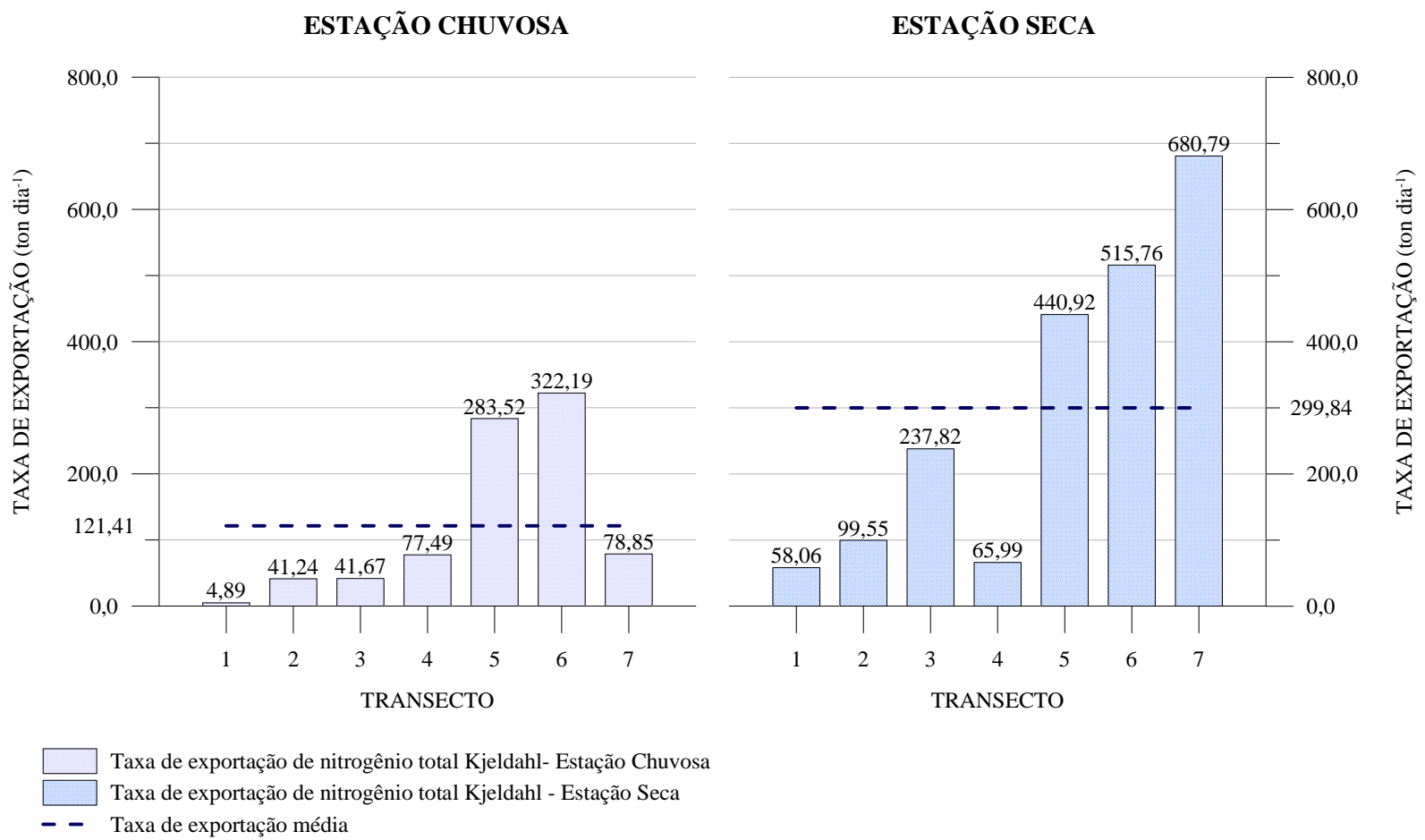

Figura 47. Taxa de exportação de nitrogênio total Kjeldahl (ton dia ${ }^{-1}$ ).

De uma maneira geral foi observado que as taxas de exportação do nutriente nitrogênio, em todas suas formas analisadas, foram superiores durante a Estação Seca, exceto para nitrito, cuja taxa foi superior na Estação Chuvosa.

Quanto as formas nitrato, nitrogênio amoniacal e nitrogênio total Kjeldahl, durante a Estação Seca, destacam-se os Transectos 5, 6 e 7, nos quais foram observadas as maiores taxas. 


\section{$\checkmark$ Fosfato total dissolvido}

No geral, as taxas de exportação de fosfato total dissolvido foram 277,59\% maiores na Estação Seca, quando os valores ficaram em torno de 47,16 $\pm 56,39$ ton dia $^{-1}$, do que na Estação Chuvosa, quando os valores ficaram em torno de 12,49 $\pm 11,22$ ton dia ${ }^{-1}$.

O comportamento crescente das taxas observadas nos Transectos 1 a 6 da Estação Seca também são observados durante a Estação Chuvosa, bem o como o decaimento evidenciado no Transecto 7, conforme a Figura 48.

Cabe ressaltar as taxas observadas nos Transectos 5 e 6, em ambas Estações. No Transecto 5, as taxas foram 111,93\% e 104,62\% maiores que as médias das Estações Chuvosa e Seca, respectivamente, enquanto que no Transecto 6 as taxas foram 120,50\% e 220,60\% maiores que a média das Estações Chuvosa e Seca, respectivamente.

Porém, tendo decaído as taxas no Transecto 7 , taxa média de exportação para o Reservatório de Três Irmãos foi de 24,38 ton dia $^{-1}$.

\section{$\checkmark$ Ortofosfato}

As taxas de exportação de ortofosfato foram 35,14\% maiores, em média, na Estação Seca, cujos valores foram de 383,86 $\pm 268,28 \mathrm{~kg} \mathrm{dia}^{-1}$, do que na Estação Chuvosa, cujos valores foram de $284,05 \pm 189,17 \mathrm{~kg} \mathrm{dia}^{-1}$, conforme mostra a Figura 49 .

Em ambas Estações destacam-se as taxas de exportação dos Transectos 5, 6 e 7, sempre acima da média. Porém, diferentemente das análises anteriores, não é evidente o decaimento das taxas no Transecto 7, que especificamente representa a exportação para o Reservatório de Três Irmãos, cuja média foi de $620,27 \mathrm{~kg} \mathrm{dia}^{-1}$. 
ESTAÇÃO CHUVOSA

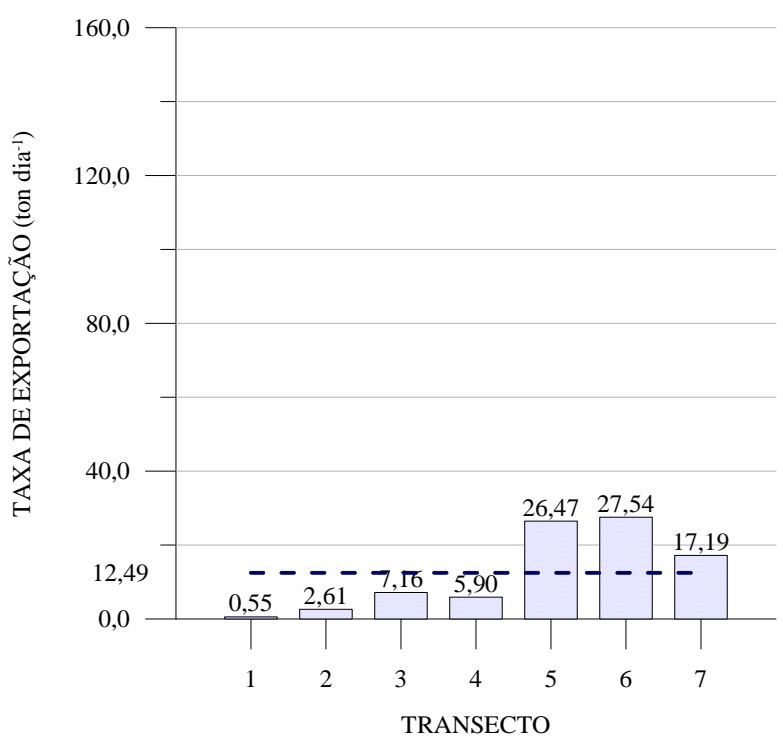

Taxa de exportação de fosfato total dissolvido - Estação Chuvosa

Taxa de exportação de fosfato total dissolvido - Estação Seca

- Taxa de exportação média
ESTAÇÃO SECA

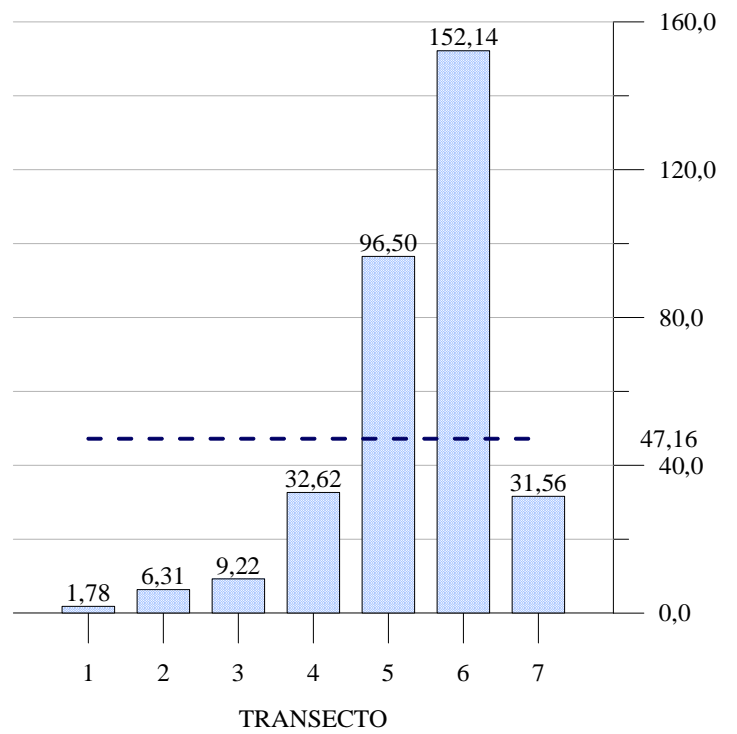

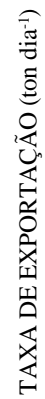

Figura 48. Taxa de exportação de fosfato total dissolvido (ton $\operatorname{dia}^{-1}$ ).

ESTAÇÃO CHUVOSA

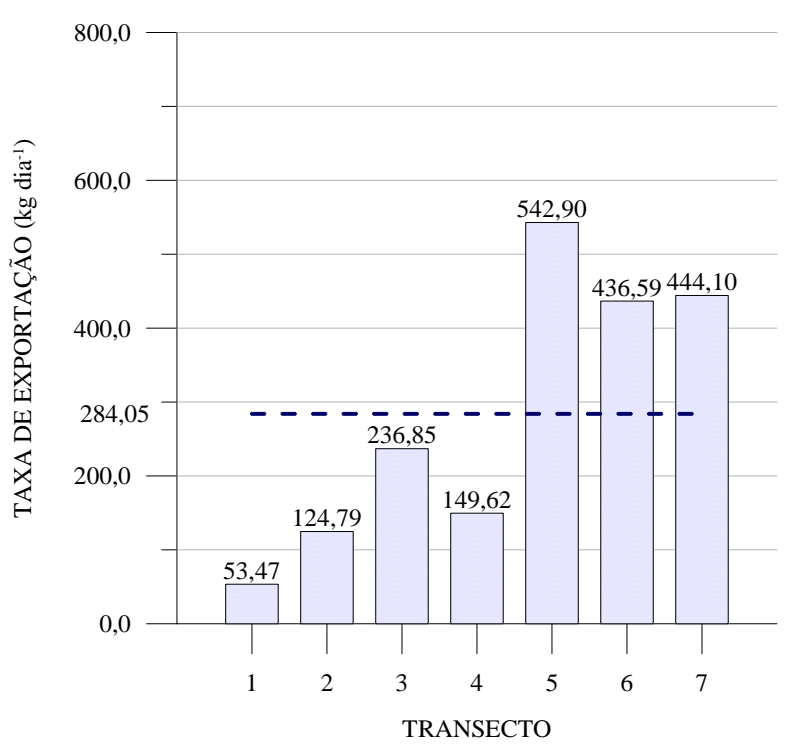

ESTAÇÃO SECA

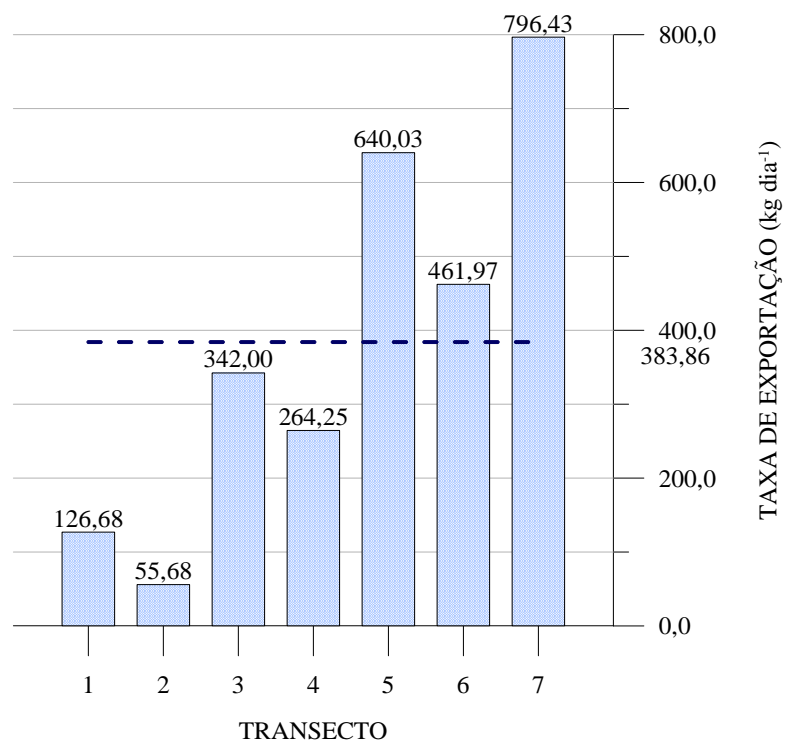

Taxa de exportação de ortofosfato - Estação Chuvosa

Taxa de exportação de ortofosfato - Estação Seca

- - Taxa de exportação média

Figura 49. Taxa de exportação de ortofosfato $\left(\mathrm{kg} \mathrm{dia}^{-1}\right)$. 


\section{$\checkmark$ Fósforo total}

Ainda, na avaliação das taxas de exportação de fósforo total observa-se o aumento da concentração dos elementos ao longo do Transectos, implicando no aumento das taxas de exportação, conforme já observado anteriormente.

Tanto na Estação Chuvosa como na Estação Seca foi observada a tendência crescente das taxas de exportação, como representado pela Figura 50. Exceto no Transecto 7, em ambas Estações, que apresentou valores que não acompanharam a tendência, mesmo ainda acima da média da Estação, ou seja, quanto ao elemento fósforo total, a taxa de exportação do Transecto 7 é menor do que as taxas dos Transectos à montante, assim como evidenciado para os elementos sólidos suspensos, nitrito, nitrato e fosfato total dissolvido.

Agora porém verificou-se uma taxa média 32\% menor na Estação Seca, cujos valores foram 10,05 $\pm 6,45$ ton $\mathrm{dia}^{-1}$, quando comparado com a Estação Chuvosa, cujos valores foram de $14,86 \pm 10,03$ ton $\mathrm{dia}^{-1}$. Isto não era observado nos nutrientes analisados anteriormente.

Para fósforo total a taxa de exportação para o Reservatório de Três Irmãos foi de 14,95 ton $\mathrm{dia}^{-1}$.

ESTAÇÃO CHUVOSA

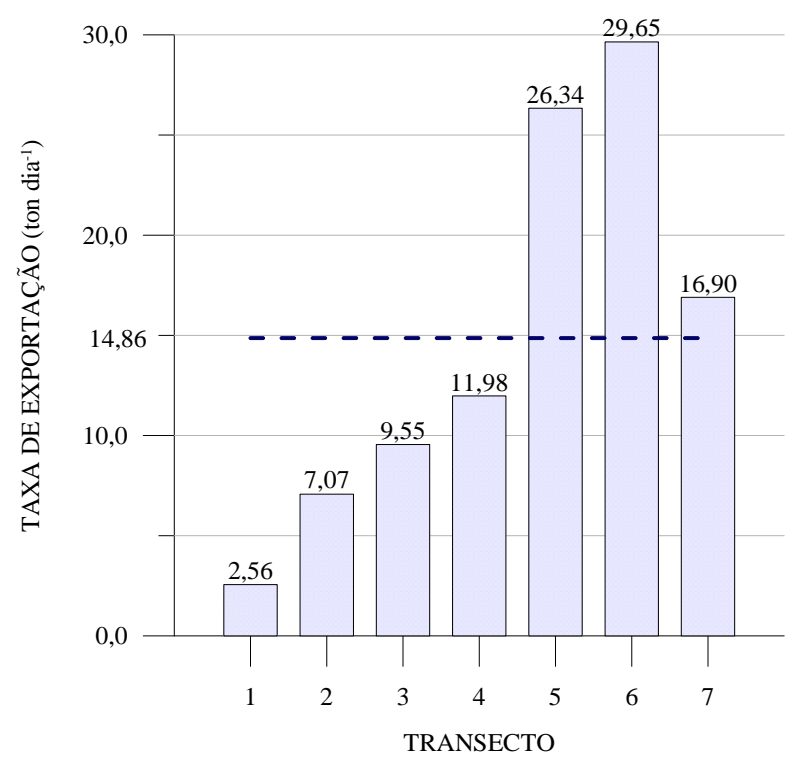

Taxa de exportação de fósforo total - Estação Chuvosa

Taxa de exportação de fósforo total - Estação Seca

- - Taxa de exportação média
ESTAÇÃO SECA

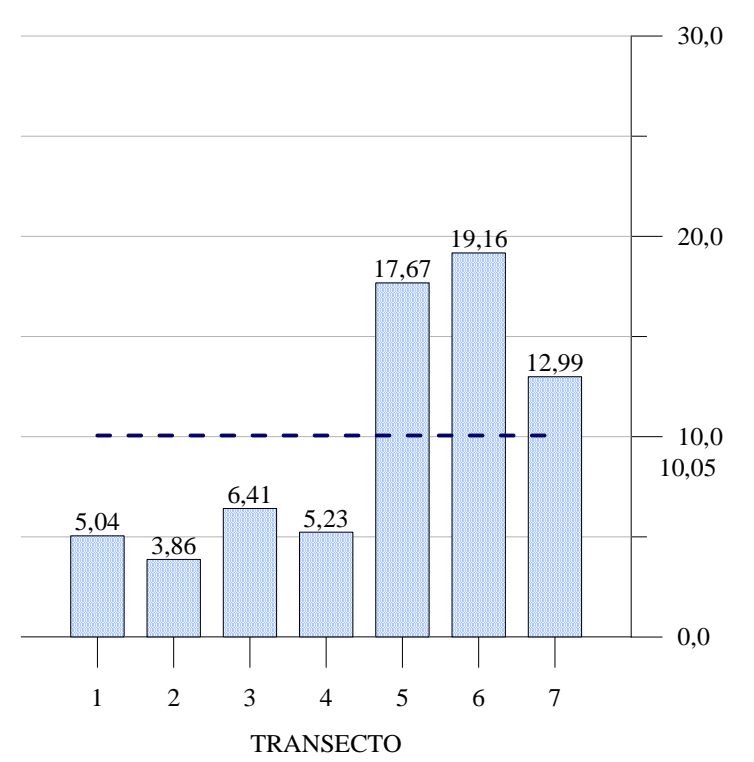

Figura 50. Taxa de exportação de fósforo total (ton $\left.\operatorname{dia}^{-1}\right)$. 


\section{$\checkmark$ Silicato reativo}

A taxa de exportação de silicato reativo foi maior na Estação Seca, cerca de 90,46\%, do que na Estação Chuvosa, sendo as maiores taxas observadas nos Transectos 5, 6 e 7, em ambas Estações, como pode ser verificado na Figura 51.

Considerando apenas o conjunto dos 4 primeiros Transectos, isto é, os Transectos 1, 2, 3 e 4, observa-se, em ambas Estações, o destaque para as taxas de exportação do Transecto 3, mesmo menores que as médias de suas respectivas Estações, são ainda maiores que as taxas dos Transectos desse conjunto.

A taxa de exportação para o Reservatório foi determinada em 598,53 ton dia $^{-1}$.

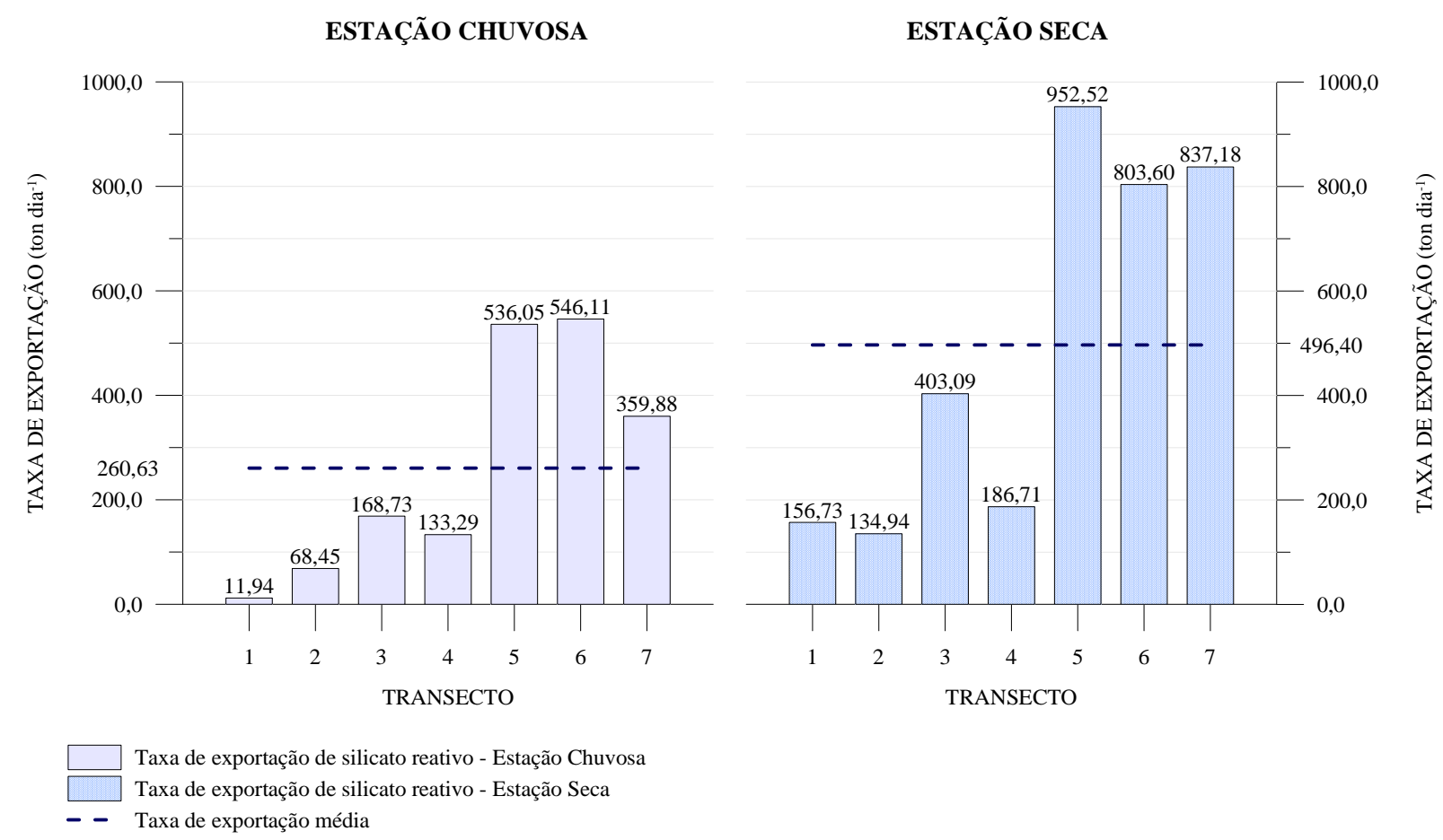

Figura 51. Taxa de exportação de silicato reativo (ton dia ${ }^{-1}$ ). 


\subsection{Sedimentos de fundo}

Diferentemente dos resultados observados até o momento, os quais referem-se à análises pontuais e momentâneas das expressões dos fenômenos que ocorriam naquele exato momento da amostragem, a análise dos sedimentos de fundo de um corpo d'água é capaz de demonstrar tendências.

Por isto, é possível considerar que através da análise dos sedimentos de fundo é possível descrever cronologicamente fenômenos que ocorriam no ambiente do entorno, tanto aquático quanto terrestre.

\section{Nitrogênio total}

A concentração de nitrogênio total nos sedimentos foi $47,38 \%$ maior durante a Estação Seca do que na Estação Chuvosa. Vale destacar a mínima concentração observada no Transecto 6 da Estação Chuvosa, com 31,92 $\mathrm{mg} \mathrm{g}^{-1}$, cerca de 453,23\% menor que a média da Estação.

No geral, a concentração de nitrogênio total foi de $176,59 \pm 73,70 \mathrm{mg} \mathrm{g}^{-1} \mathrm{e}$ 260,26 $\pm 107,03 \mathrm{mg} \mathrm{g}^{-1}$, nas Estações Chuvosa e Seca, respectivamente, conforme Figura 52.

Esses valores são muito superiores ao encontrados por Moccellin (2006 e 2010), cujos maiores valores encontrados foram de $1,41 \mathrm{mg} \mathrm{g}^{-1}$ e $0,42 \mathrm{mg} \mathrm{g}^{-1}$, mas deve-se considerar que a autora realizou seus trabalhos num sistema lótico, cujo fluxo é maior do que em um sistema lêntico e cujos sedimentos eram compostos basicamente pela fração areia.

No entanto, ainda são muito superiores aos valores encontrados por Bramorski (2004) no Reservatório de Barra Bonita, com 7,5 $\mathrm{mg} \mathrm{g}^{-1}$ de nitrogênio total.

\section{$\checkmark$ Fósforo total}

As concentrações de fósforo total observadas, cujos valores foram de $2,70 \pm 1,56 \mu \mathrm{g} \mathrm{g}^{-1}$ na Estação Chuvosa são apenas 2,27\% maiores que as concentrações observadas na Estação Seca, com valores na ordem de 2,64 $\pm 1,26 \mu \mathrm{g} \mathrm{g}^{-1}$. 
Esses valores são bem inferiores ao encontrados pelos seguintes autores: Esteves (1998) que encontrou concentração de 513,6 $\mu_{\mathrm{g} \mathrm{g}} \mathrm{g}^{-1}$ no reservatório de Barra Bonita; Carmo (2000) que encontrou valores de até $1673 \mu \mathrm{g} \mathrm{g}^{-1}$ no Lago das Garças; Leite (2002), no Reservatório de Salto Grande, que não encontrou concentrações superiores à $600 \mu \mathrm{g} \mathrm{g}^{-1}$; e Bramorski (2004), também em Barra Bonita, que encontrou concentração de $1092,7 \mu \mathrm{g} \mathrm{g}^{-1} \mathrm{e}$ de 743,0 $\mu \mathrm{g} \mathrm{g}^{-1}$ no Rio Piracicaba.

Porém são superiores às concentrações encontradas por Moccellin (2006 e 2010) no Rio Jacupiranguinha e no Rio Pariquera-Açu, cujas concentrações máximas foram de 1,7 e $1,0 \mu \mathrm{g} \mathrm{g}^{-1}$, respectivamente.

\section{$\checkmark$ Matéria orgânica}

Como pode ser observado na Figura 54, as concentrações de matéria orgânica dos sedimentos foram superiores na Estação Chuvosa, cerca 84,91\% maiores. Na Estação Chuvosa, apenas os Transectos 4 e 7 apresentaram concentração acima de 10\%, com destaque para o Transecto com $38,38 \%$.

CAVENAGHI et al. (2005), estudando os sedimentos do Reservatório da UHE Mogi Guaçu encontrou concentração média de $35,27 \mathrm{~g} \mathrm{~kg}^{-1}$, que equivale a 3,53\%, ou seja, abaixo dos valores médios encontrados nesse trabalho, inclusive durante a Estação Seca, cujos valores foram de $6,89 \%$.

Porém, os valores encontrados nesse trabalho são superiores aos valores encontrados por Rodgher et al. (2005) num estudo realizado no sistema de reservatórios em cascata no Rio Tietê, quando, ao analisar os sedimentos do Reservatório de Três Irmãos encontraram concentração de matéria orgânica na ordem de $0,3 \%$ e $0,5 \%$ nos sedimentos à monte e à jusante da barragem, respectivamente. 

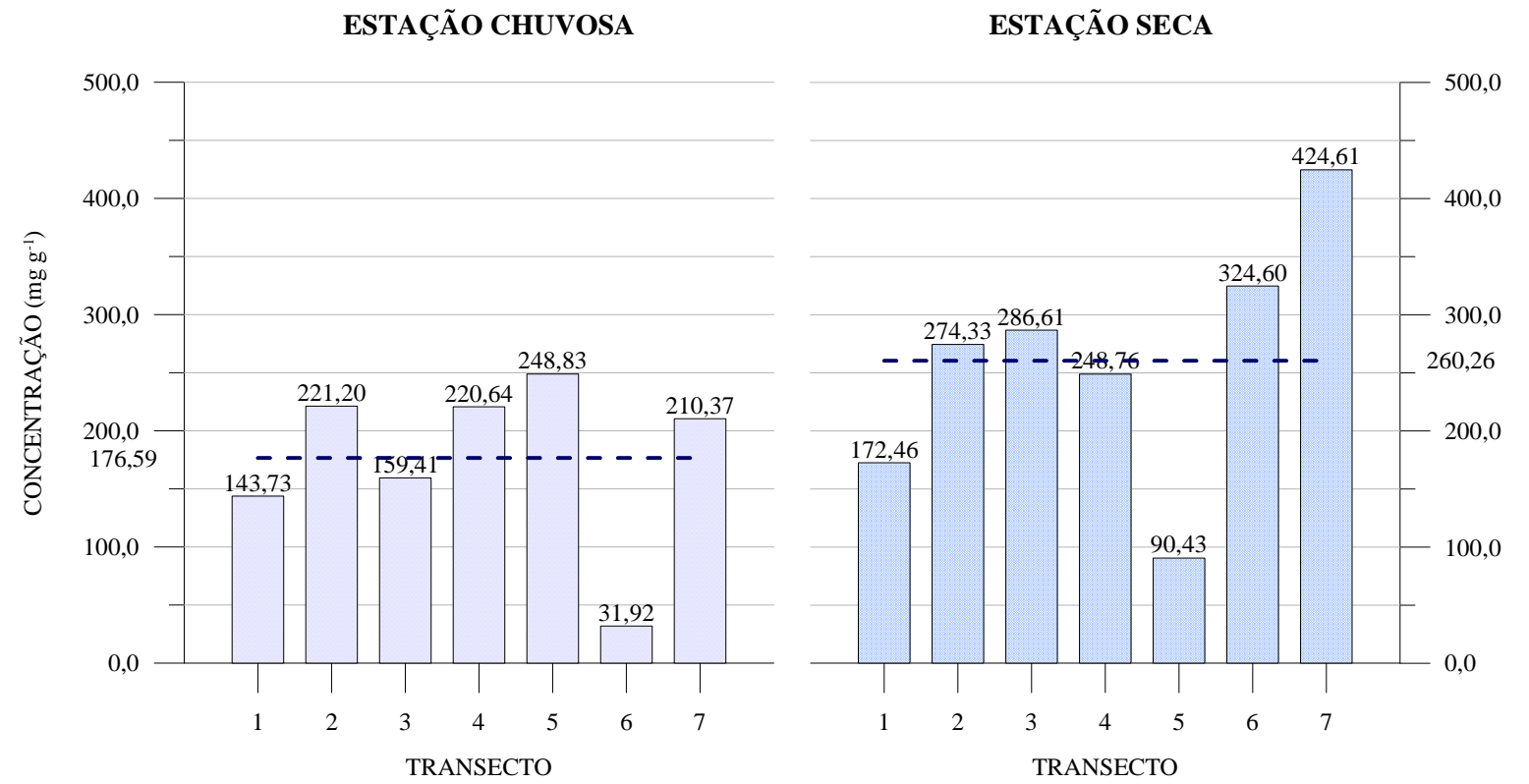

Concentração de nitrogênio total nos sedimentos - Estação Chuvosa

Concentração de nitrogênio total nos sedimentos - Estação Seca

- Concentração média

Figura 52. Concentração de nitrogênio total nos sedimentos de fundo ( $\left.\mathrm{mg} \mathrm{g}^{-1}\right)$.

ESTAÇÃO CHUVOSA

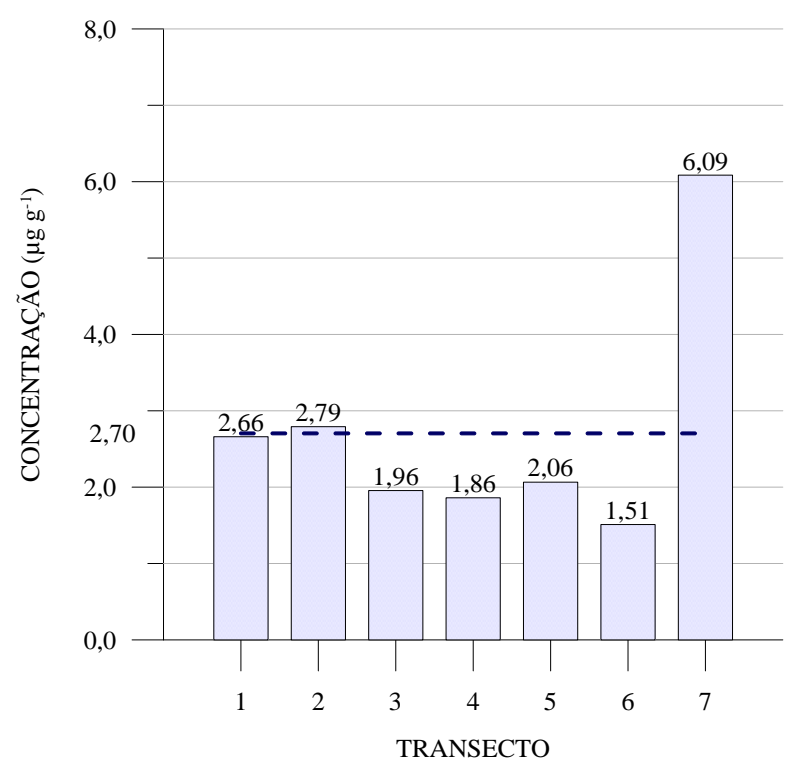

Concentração de fósforo total nos sedimentos - Estação Chuvosa Concentração de fósforo total nos sedimentos - Estação Seca

- - Concentração média
ESTAÇÃO SECA

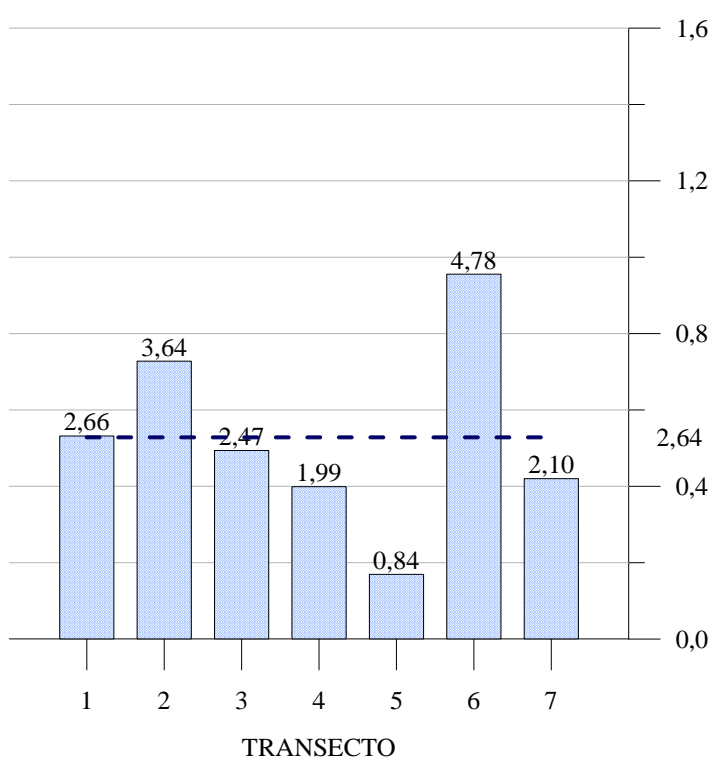

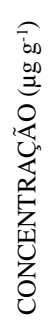

Figura 53. Concentração de fósforo total nos sedimentos de fundo $\left(\mu \mathrm{g} \mathrm{g}^{-1}\right)$. 
ESTAÇÃO CHUVOSA

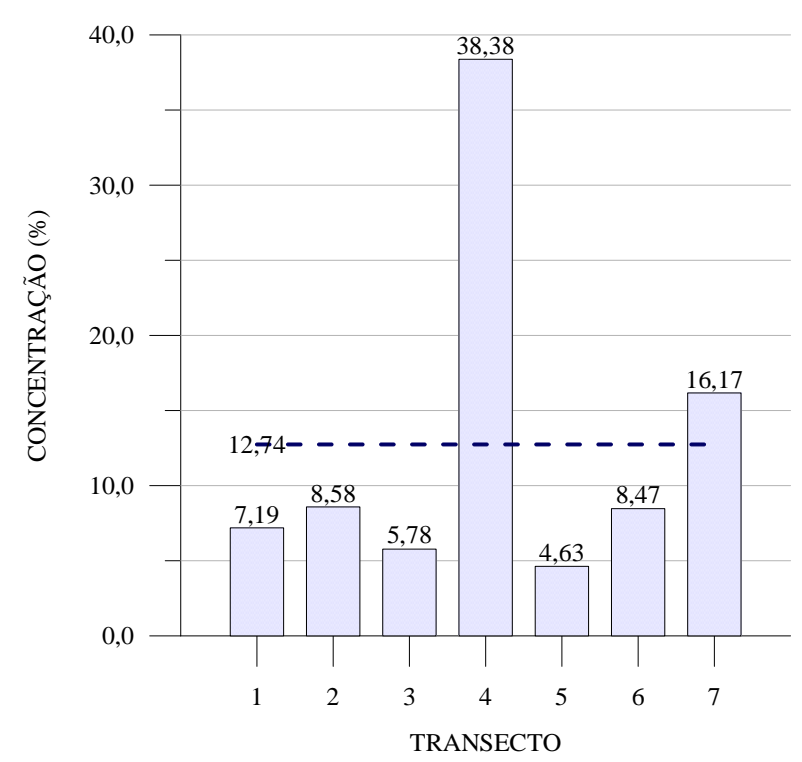

Concentração de Matéria Orgânica nos sedimentos - Estação Chuvosa Concentração de Matéria Orgânica nos sedimentos - Estação Seca - - Concentração média
ESTAÇÃO SECA

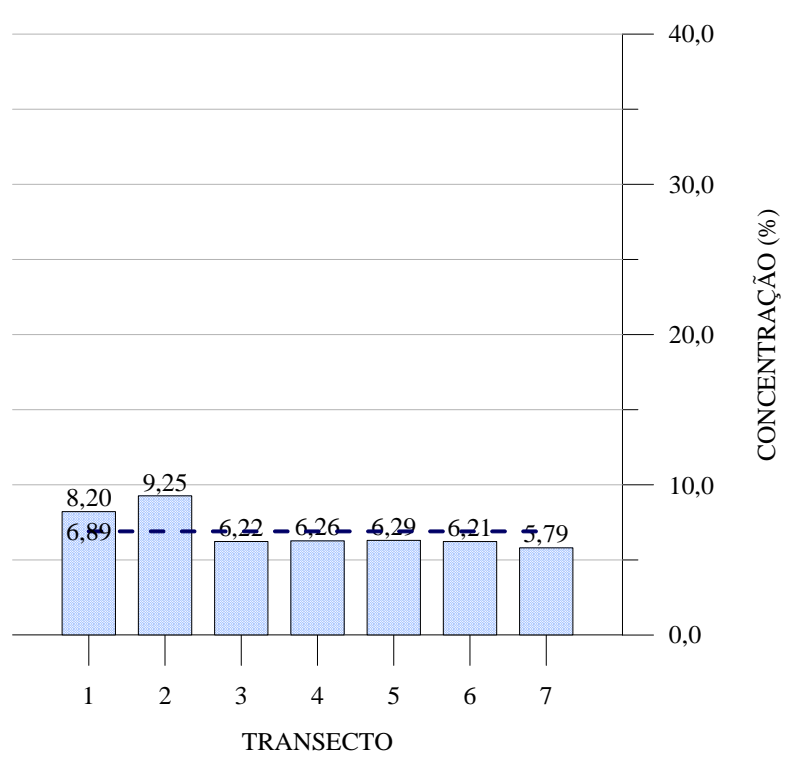

Figura 54. Concentração de matéria orgânica nos sedimentos de fundo (\%).

Cabe ressaltar que altas taxas de deposição de nutrientes combinadas com altas concentrações desses nutrientes nos sedimentos, mesmo controlando-se o aporte de novas quantidades de nutrientes, os sedimentos de fundo têm potencial de liberação de nutrientes para a coluna de água por um período muito longo de tempo (SOARES e MOZETO, 2006).

As elevadas taxas de nutrientes presentes na sub-bacia podem ocasionar bloom de algas cujas consequências podem influenciar diversas atividades, desde a geração de energia elétrica até a captação de água para tratamento e abastecimento público. Estudos realizados no Reservatório de Três Irmãos verificaram a presença de $196800 \mathrm{~m}^{2}$ de área infestados com plantas aquáticas (TANAKA et al., 2002), sendo mais frequentemente encontradas as seguintes espécies: lodinho (Egeria najas), aguapé (Eichhornia crassipes), candelabro aquático (Ceratophyllum demersum), (Najas guadalupensis), erva-de-bicho (Polygonum hydropiperoides), salvínia (Salvinia molesta). 


\section{$\checkmark$ Granulometria}

Ainda observa-se que não há um método adequado que forneça garantia de obtenção de resultados satisfatórios nos estudos dos sedimentos, principalmente no que diz respeito à composição granulométrica dos sedimentos, ou seja, a distribuição das frações areia, silte e argila.

Isto já era evidente em 1966, segundo o sedimentólogo Folk (1966). Por isto, a inspeção visual da curva granulométrica e o estudo das relações entre partículas deve ser utilizado para melhor compreender o significado da distribuição que está sendo observada, bem como deve servir de subsídio para caracterizar a origem do depósito e os processos de transporte e sedimentação.

Diante disto, foram analisadas as curvas granulométricas das amostras de sedimentos de fundo coletadas na margem direita, no centro e na margem esquerda de cada um dos Transectos, nas Estações Chuvosa e Seca. A partir da curva granulométrica foi possível identificar a composição aproximada da amostra em termos das porcentagens das frações areia, silte e argila e desta forma foi possível classificar o sedimento segundo a proposta de Flemming (2000), utilizando diagramas ternários que relacionam as quantidades das frações de areia, silte e argila presentes na amostra.

Desta forma, na Figura 62 está representado o diagrama ternário de classificação dos sedimentos da Estação Chuvosa e na Figura 63 está representado o diagrama ternário de classificação dos sedimentos da Estação Seca. Estes diagramas foram sintetizados na Tabela 17 que apresenta a classificação completa, descritiva, desses sedimentos.

Assim, de acordo com a análise da curva granulométrica dos sedimentos do Transecto 1, conforme representado pela Figura 55, não foi observado mudanças significativas entre as Estações Chuvosa e Seca, ou seja, os sedimentos, tanto da margem direita, quanto do centro e da margem esquerda, não sofreram alteração significativa na composição entre as Estações, exceto no centro, cuja fração areia foi superior na Estação Seca.

Foi verificado que nos sedimentos da margem direita há predomínio da fração areia em relação às frações de silte e argila, o que indica aporte recente de sedimentos, considerando a dinâmica dos processos de sedimentação, sendo desta forma classificados como areia argilosa. 
Já na margem esquerda foi observado predomínio da fração argila, indicando um processo de sedimentação mais tardio do que o observado na margem direita. Neste sentido, é possível inferir que o aporte de sedimentos na margem direita é maior que o aporte de sedimentos na margem esquerda desse Transecto. Nesta margem os sedimentos foram classificados como areia siltosa, na Estação Chuvosa, e como lodo muito argiloso extremamente siltoso na Estação Seca.

Alterações mais significativas na composição dos sedimentos foram observadas ao centro do Transecto. Tanto que sua classificação variou de areia argilosa na Estação Chuvosa para lodo arenoso muito argiloso na Estação seguinte.
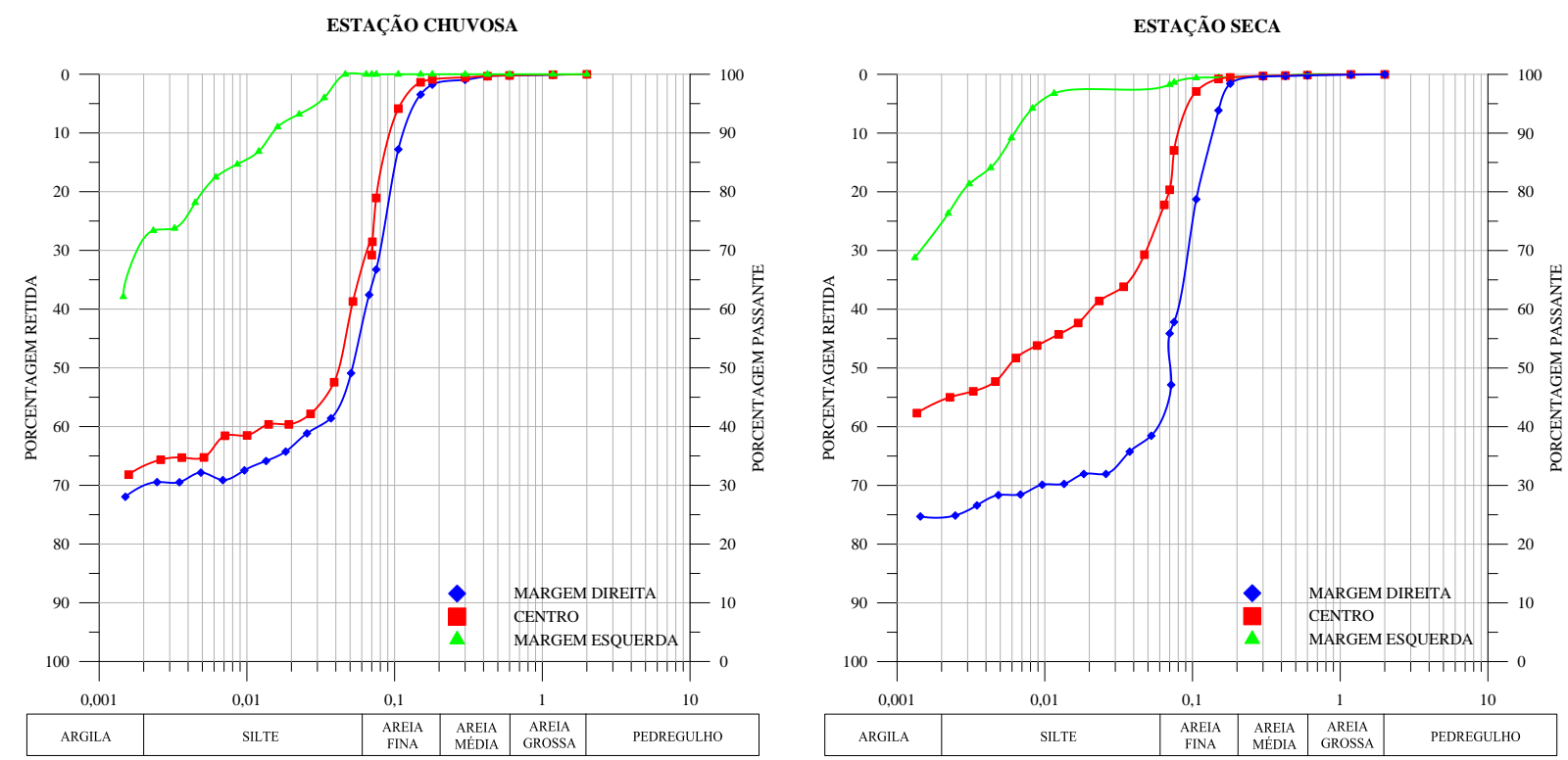

Figura 55. Granulometria dos sedimentos de fundo do Transecto 1 do Ribeirão das Cruzes nas Estações Chuvosa e Seca.

No Transecto 2, conforme representado pela Figura 56, ainda é possível observar o predomínio da fração areia sobre as demais frações, tanto na Estação Chuvosa como na Estação Seca. Com isto, é possível inferir que as características de aporte dos sedimentos na margem direta, entre o Transecto 1 e o Transecto 2, permanecem semelhantes.

No entanto, entre as Estações, houve aporte de novos sedimentos que influenciaram a composição granulométrica dos sedimentos da margem esquerda e do centro na Estação Seca, pois nessa Estação foi observado acréscimo da fração areia. 
Desta forma, segundo a curva granulométrica, os sedimentos da margem direita foram classificados como areia argilosa, já o sedimentos do centro e da margem esquerda foram classificados como lodo muito argiloso ligeiramente arenoso, na Estação Chuvosa.

Porém, na Estação Seca os sedimentos da margem direita foram classificados como areia ligeiramente argilosa e os sedimentos do centro e margem esquerda foram classificados como lodo arenoso muito argiloso.
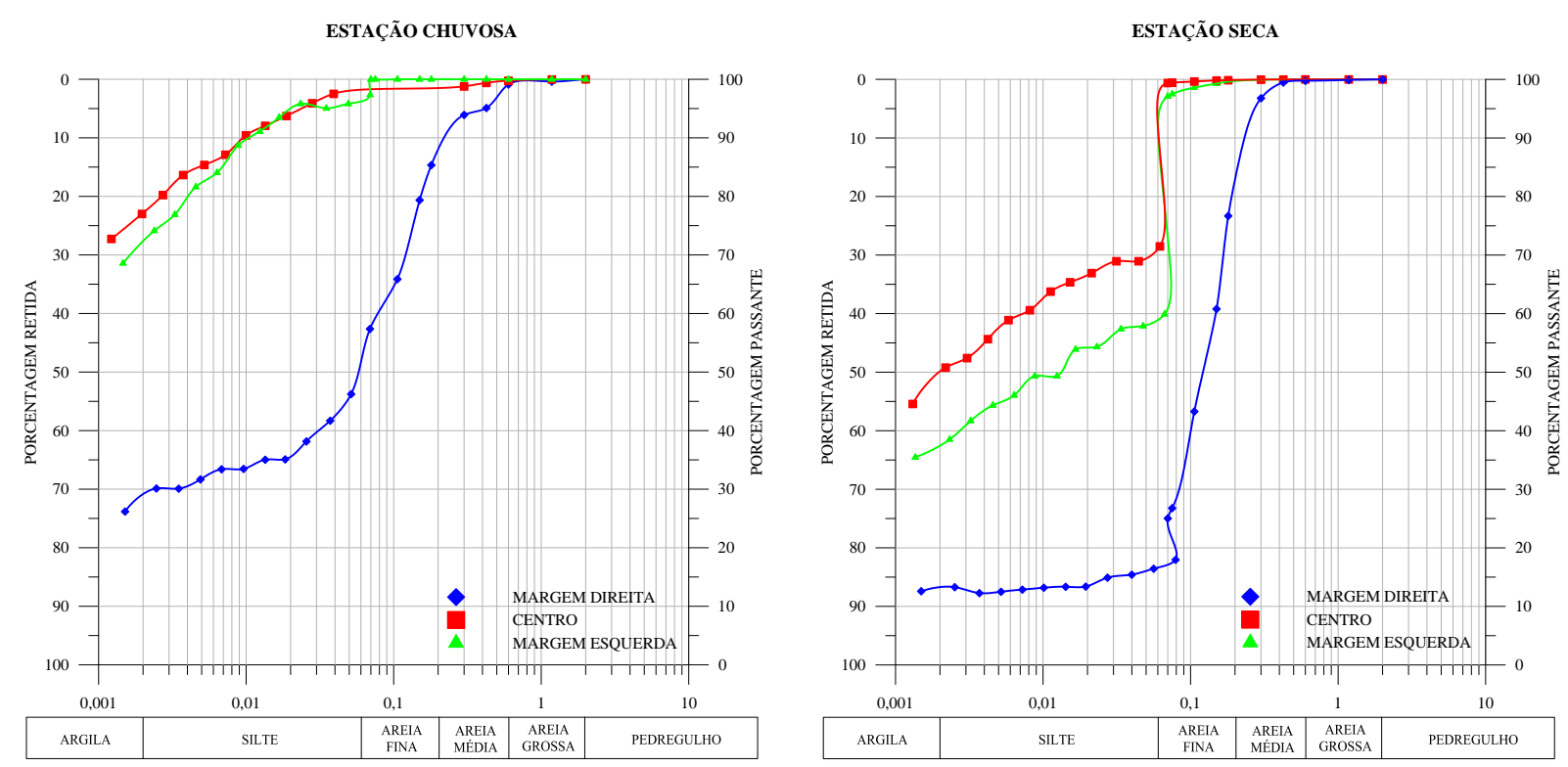

Figura 56. Granulometria dos sedimentos de fundo do Transecto 2 do Ribeirão das Cruzes nas Estações Chuvosa e Seca.

No Transecto 3, foi observado alterações significativas na composição granulométrica dos sedimentos, principalmente na margem esquerda, conforme Figura 57, indicando mudança na dinâmica do aporte de sedimentos.

Até o momento, a análise da composição granulométrica dos Transectos 1 e 2 indicava aporte de novos sedimentos apenas na margem direita, pois somente nesta margem predominava a fração areia. No entanto, em ambas Estações, na margem esquerda do Transecto 3 passa a predominar a fração areia, indicando naquela margem há fonte significativa de aporte capaz de influenciar bruscamente a composição granulométrica dos sedimentos daquela margem. 
É possível inferir até que este aporte na margem esquerda influencia a composição granulométrica dos sedimentos do centro do transecto, que na Estação Seca apresenta característica mais arenosa do que apresentava no Transecto 2.

Nestas circunstâncias os sedimentos foram classificados como areia ligeiramente argilosa e areia ligeiramente siltosa, nas margens direita e esquerda, respectivamente, e como lodo muito argiloso ligeiramente arenoso no centro, na Estação Chuvosa. Já na Estação Seca os sedimentos foram classificados como areia ligeiramente argilosa nas margens direita e esquerda, e como lodo arenoso muito argiloso no centro.
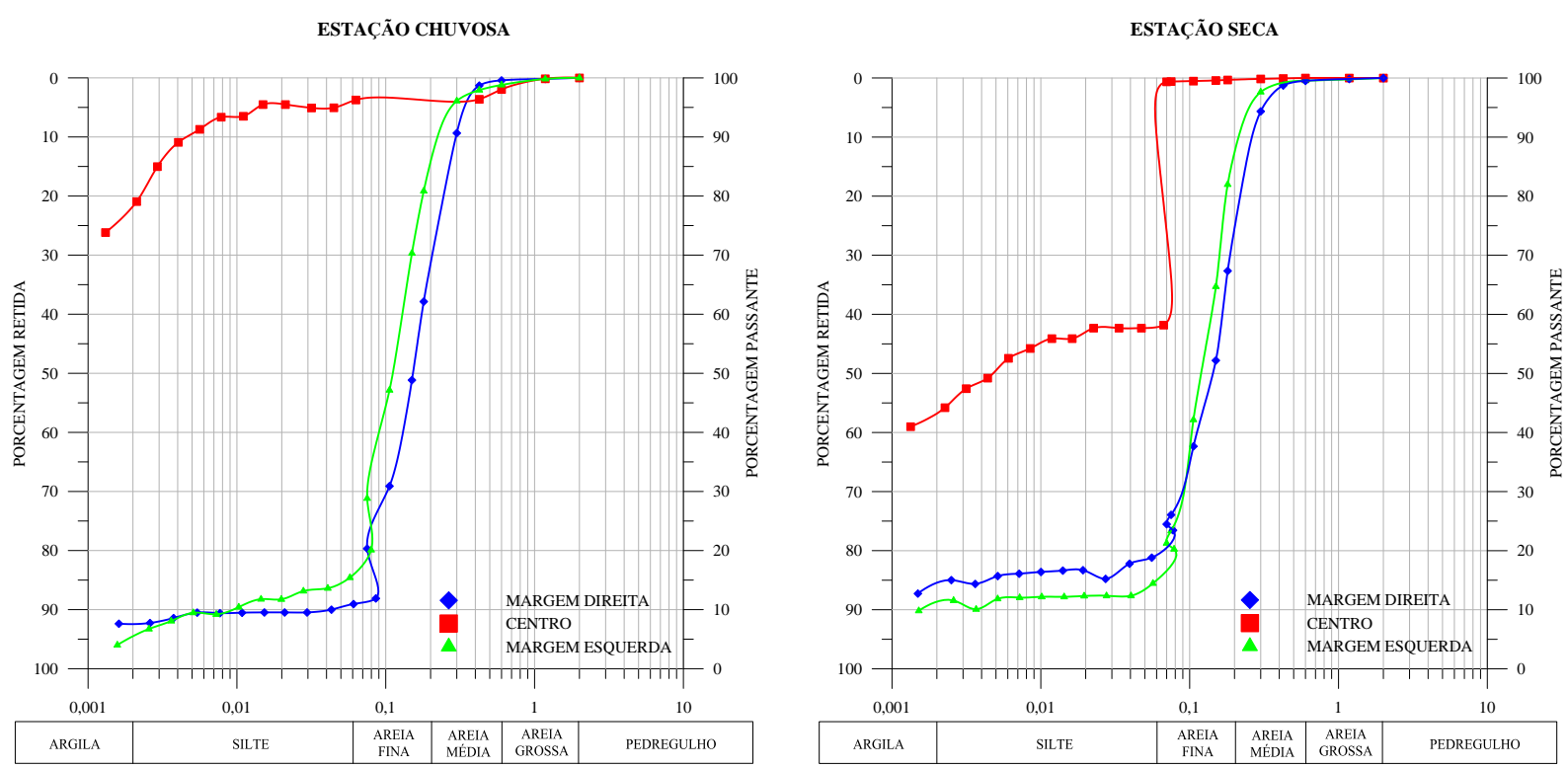

Figura 57. Granulometria dos sedimentos de fundo do Transecto 3 do Ribeirão das Cruzes nas Estações Chuvosa e Seca.

A localização do Transecto 4, conforme Figura 8, fornece informações a respeito de uma micro bacia afluente ao Ribeirão das Cruzes, que segundo as curvas granulométricas de seus sedimentos de fundo, representadas na Figura 58, indica o predomínio da fração areia nas margens direita e esquerda do Transecto, indicando que a bacia de contribuição está fornecendo sedimentos, recentes, ao corpo d'água.

Neste Transecto a classificação foi mais homogênea sendo todos sedimentos classificados como areias. Na Estação Chuvosa os sedimentos da margem direita e esquerda foram classificados como areia ligeiramente siltosa, sendo que na Estação Seca foram classificados como areia ligeiramente argilosa. Em ambas Estações os sedimentos do centro do Transecto foram classificados como areia muito argilosa. 

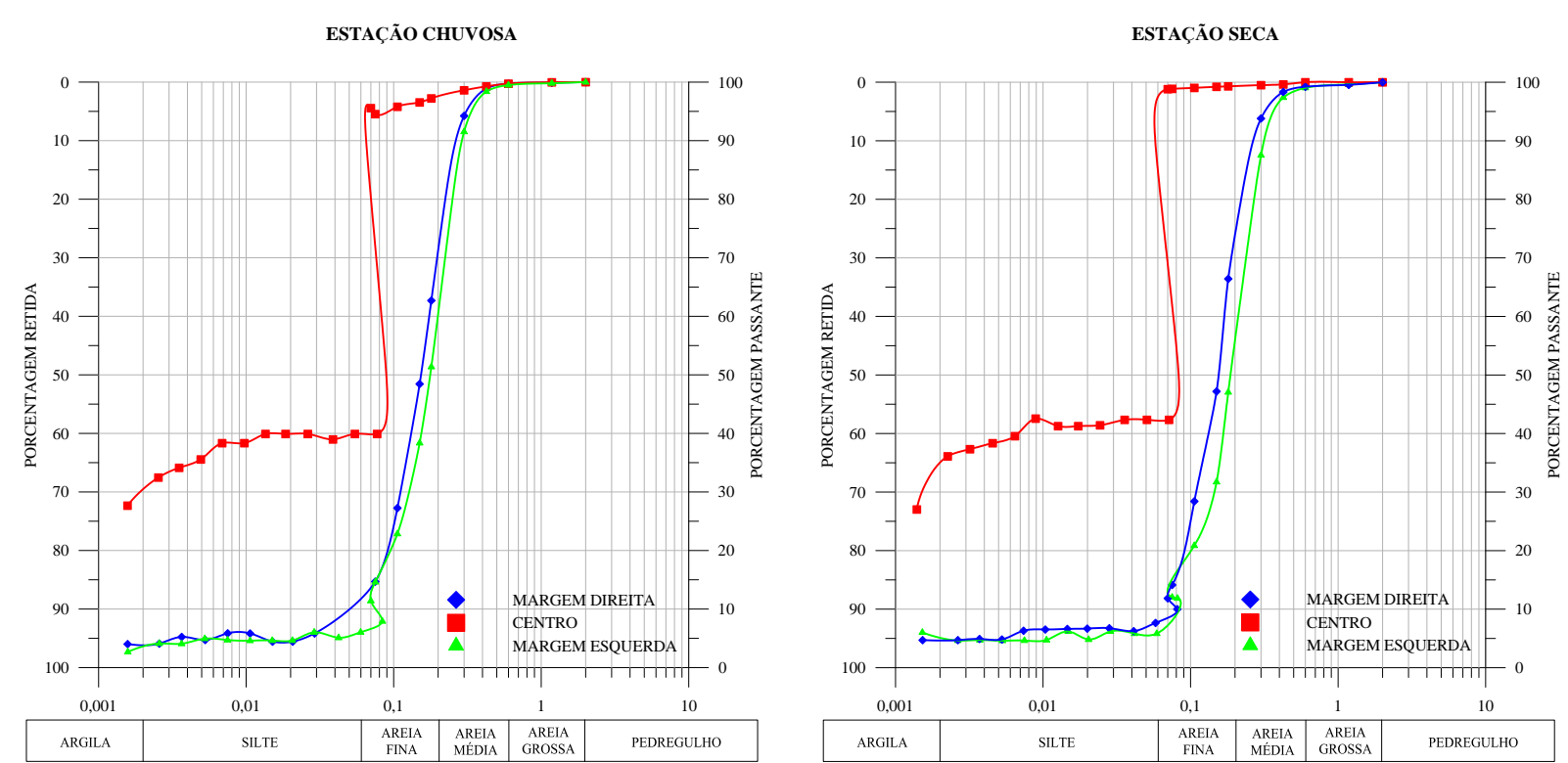

Figura 58. Granulometria dos sedimentos de fundo do Transecto 4 do Ribeirão das Cruzes nas Estações Chuvosa e Seca.

Na sequência do fluxo da água no Ribeirão das Cruzes, a análise granulométrica dos sedimentos dos Transectos 5, 6 e 7, conforme representado pelas Figura 59, 61 e 62 respectivamente, não indicam mudanças significativas nas composições, mantendo-se a característica, por exemplo, do Transecto 4.

Isto é, pode-se afirmar que nas margens esquerda e direita dos transectos está ocorrendo o aporte de novos sedimentos, devido ao predomínio da fração areia sobre as demais frações, e que isto é observado tanto nas Estações Chuvosa e Seca.

Ainda, é possível concluir que, mesmo com maior velocidade de transporte ao centro, junto ao leito original do Ribeirão das Cruzes antes do represamento, a largura dos Transectos 4, 5 e 6, os sedimentos proveniente das margens direita e esquerda são capazes de influenciar a composição dos sedimentos do centro.

A classificação dos sedimentos nos Transectos 5, 6 e 7 foi bastante uniforme. Na Tabela 17 estão as classificações de todos os sedimentos estudados neste trabalho. 
ESTAÇÃO CHUVOSA

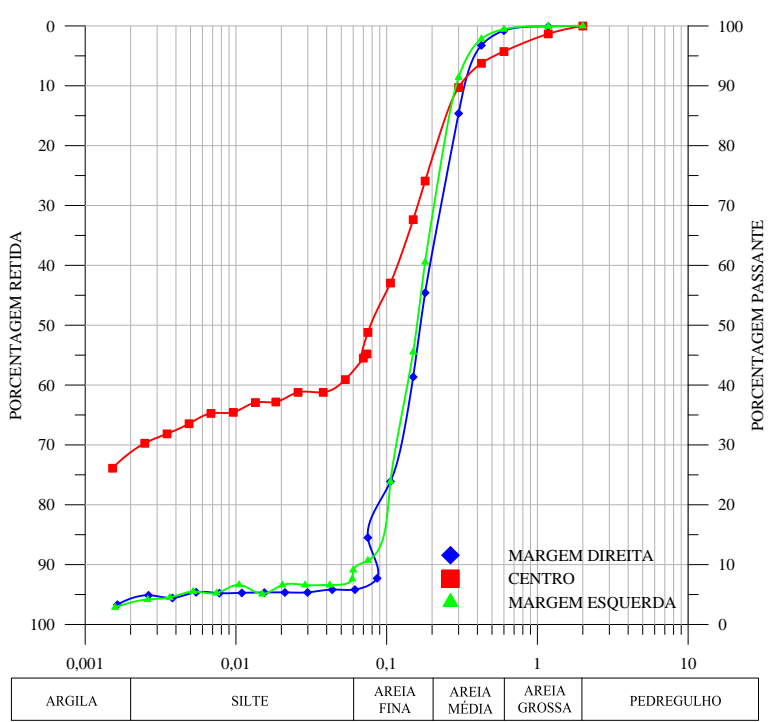

ESTAÇÃO SECA

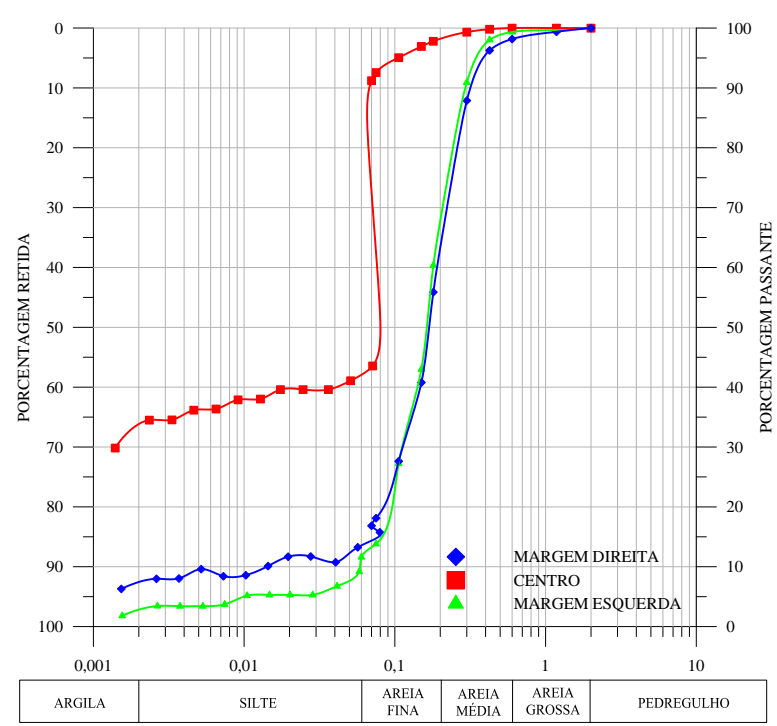

Figura 59. Granulometria dos sedimentos de fundo do Transecto 5 do Ribeirão das Cruzes nas Estações Chuvosa e Seca.

ESTAÇÃO CHUVOSA

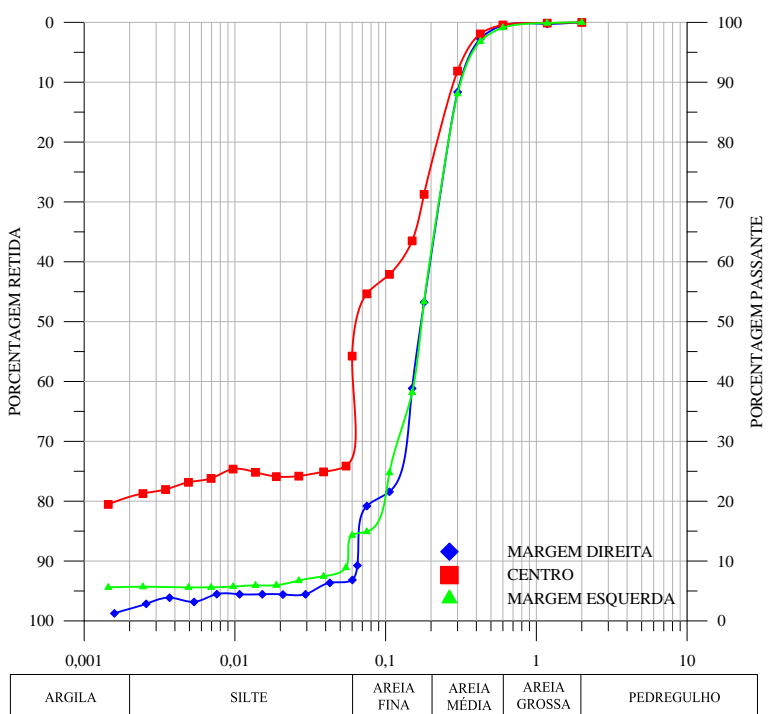

ESTAÇÃO SECA

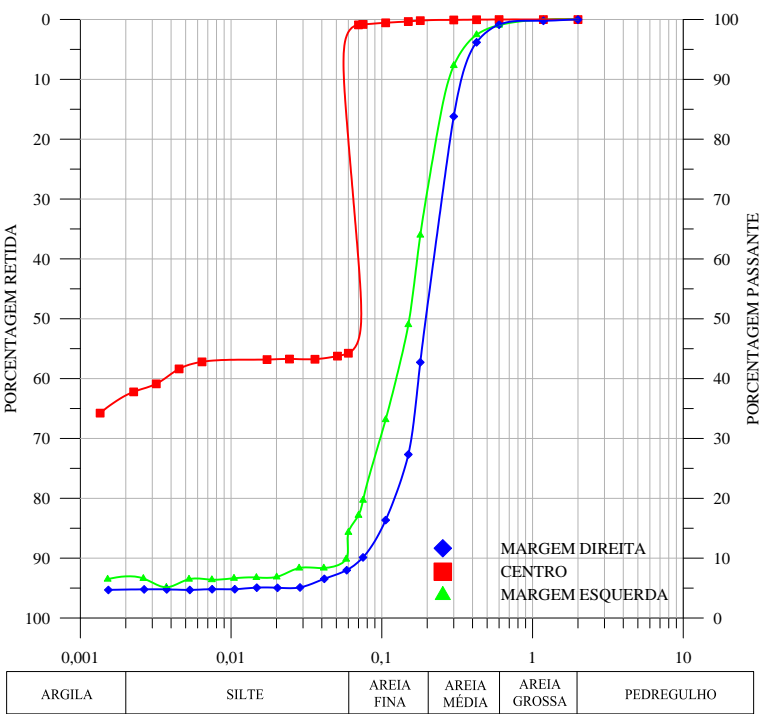

Figura 60. Granulometria dos sedimentos de fundo do Transecto 6 do Ribeirão das Cruzes nas Estações Chuvosa e Seca. 

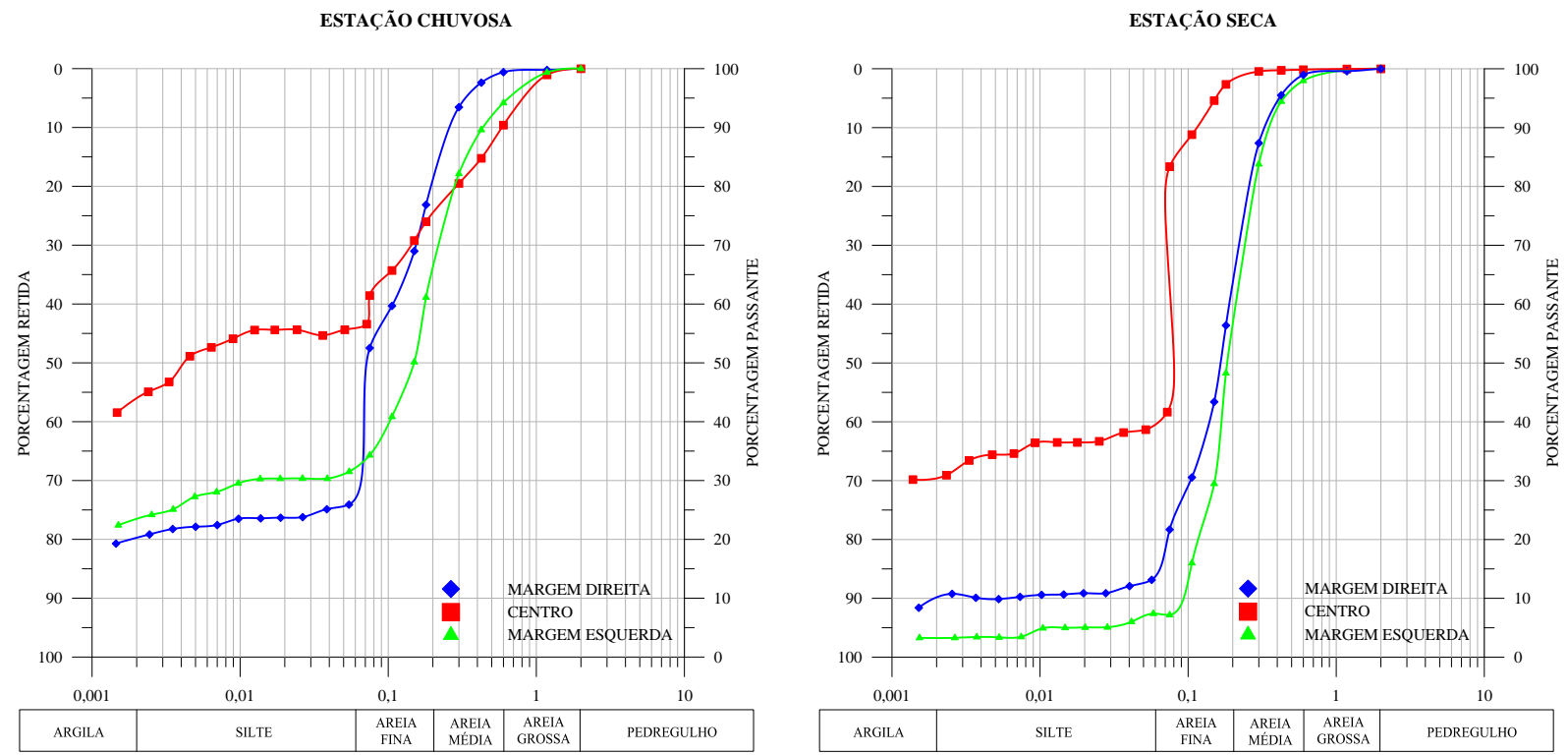

Figura 61. Granulometria dos sedimentos de fundo do Transecto 7 do Ribeirão das Cruzes nas Estações Chuvosa e Seca. 


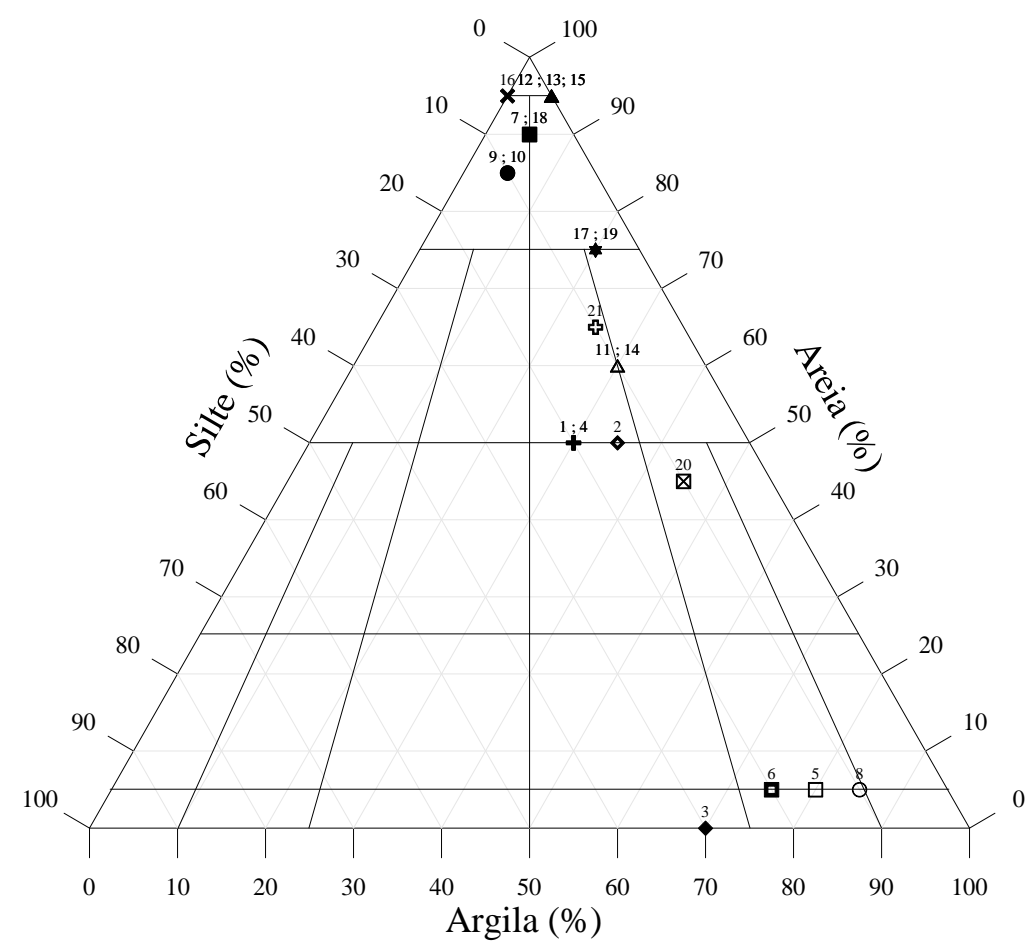

\begin{tabular}{|c|c|}
\hline \multicolumn{2}{|r|}{ Legenda } \\
\hline+ & 1 - Transecto 1 - Margem Direita \\
\hline$\diamond$ & 2 - Transecto 1 - Centro \\
\hline$\bullet$ & 3 - Transecto 1 - Margem Esquerda \\
\hline+ & 4 - Transecto 2 - Margem Direita \\
\hline$\square$ & 5 - Transecto 2 - Centro \\
\hline 口 & 6 - Transecto 2 - Margem Esquerda \\
\hline घ & 7 - Transecto 3 - Margem Direita \\
\hline 0 & 8 - Transecto 3 - Centro \\
\hline$\bullet$ & 9 - Transecto 3 - Margem Esquerda \\
\hline$\bullet$ & 10 - Transecto 4 - Margem Direita \\
\hline$\Delta$ & 11 - Transecto 4 - Centro \\
\hline $\boldsymbol{\Delta}$ & 12 - Transecto 4 - Margem Esquerda \\
\hline$\Delta$ & 13 - Transecto 5 - Margem Direita \\
\hline$\Delta$ & 14 - Transecto 5 - Centro \\
\hline$\Delta$ & 15 - Transecto 5 - Margem Esquerda \\
\hline $\mathbf{x}$ & 16 - Transecto 6 - Margem Direita \\
\hline * & 17 - Transecto 6 - Centro \\
\hline - & 18 - Transecto 6 - Margem Esquerda \\
\hline$\star$ & 19 - Transecto 7 - Margem Direita \\
\hline$\otimes$ & 20 - Transecto 7 - Centro \\
\hline њ & 21 - Transecto 7 - Margem Esquerda \\
\hline
\end{tabular}

Figura 62. Diagrama ternário dos sedimentos na Estação Chuvosa.

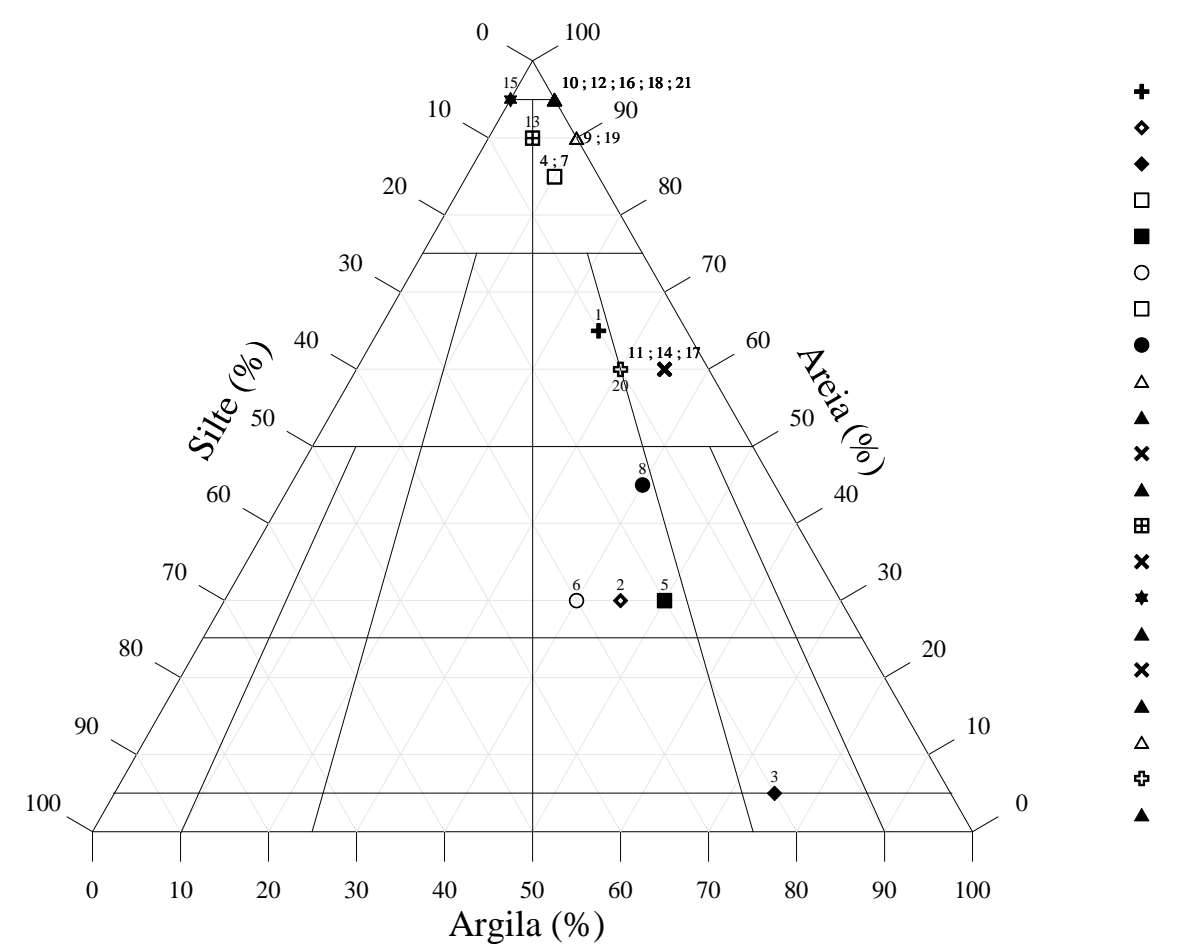

Legenda

1 - Transecto 1 - Margem Direita

2 - Transecto 1 - Centro

3 - Transecto 1 - Margem Esquerda

4 - Transecto 2 - Margem Direita

5 - Transecto 2 - Centro

6 - Transecto 2 - Margem Esquerda

7 - Transecto 3 - Margem Direita

8 - Transecto 3 - Centro

9 - Transecto 3 - Margem Esquerda

10 - Transecto 4 - Margem Direita

11 - Transecto 4 - Centro

12 - Transecto 4 - Margem Esquerda

13 - Transecto 5 - Margem Direita

14 - Transecto 5 - Centro

15 - Transecto 5 - Margem Esquerda

16 - Transecto 6 - Margem Direita

17 - Transecto 6 - Centro

18 - Transecto 6 - Margem Esquerda

19 - Transecto 7 - Margem Direita

20 - Transecto 7 - Centro

21 - Transecto 7 - Margem Esquerda

Figura 63. Diagrama ternário dos sedimentos na Estação Seca. 
Tabela 17. Classificação dos sedimentos segundo a proposta de Flemming (2000).

\begin{tabular}{|c|c|c|c|}
\hline \multirow{2}{*}{ 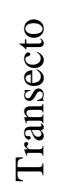 } & \multirow{2}{*}{ Ponto } & \multicolumn{2}{|c|}{ Classificação } \\
\hline & & Estação Chuvosa & Estação Seca \\
\hline \multirow{4}{*}{1} & Margem Direita & B-III - Areia argilosa & B-III - Areia argilosa \\
\hline & Centro & B-III - Areia argilosa & CV - Lodo arenoso muito argiloso \\
\hline & Margem Esquerda & E-IV - Argila siltosa & $\begin{array}{l}\text { DV - Lodo muito argiloso } \\
\text { ligeiramente arenoso }\end{array}$ \\
\hline & Margem Direita & B-III - Areia argilosa & AII - Areia ligeiramente argilosa \\
\hline \multirow[t]{3}{*}{2} & Centro & $\begin{array}{l}\text { DV - Lodo muito argiloso } \\
\text { ligeiramente arenoso }\end{array}$ & CV - Lodo arenoso muito argiloso \\
\hline & Margem Esquerda & $\begin{array}{l}\text { DV - Lodo muito argiloso } \\
\text { ligeiramente arenoso }\end{array}$ & CV - Lodo arenoso muito argiloso \\
\hline & Margem Direita & AII - Areia ligeiramente argilosa & AII - Areia ligeiramente argilosa \\
\hline \multirow[t]{3}{*}{3} & Centro & $\begin{array}{l}\text { DV - Lodo muito argiloso } \\
\text { ligeiramente arenoso }\end{array}$ & CV - Lodo arenoso muito argiloso \\
\hline & Margem Esquerda & AI - Areia ligeiramente siltosa & AII - Areia ligeiramente argilosa \\
\hline & Margem Direita & AI - Areia ligeiramente siltosa & AII - Areia ligeiramente argilosa \\
\hline \multirow[t]{3}{*}{4} & Centro & BIV - Areia muito argilosa & BIV - Areia muito argilosa \\
\hline & Margem Esquerda & AI - Areia ligeiramente siltosa & AII - Areia ligeiramente argilosa \\
\hline & Margem Direita & AII - Areia ligeiramente argilosa & AII - Areia ligeiramente argilosa \\
\hline \multirow[t]{3}{*}{5} & Centro & BIV - Areia muito argilosa & BIV - Areia muito argilosa \\
\hline & Margem Esquerda & AII - Areia ligeiramente argilosa & AI - Areia ligeiramente siltosa \\
\hline & Margem Direita & $\mathrm{AI}$ - Areia ligeiramente siltosa & AII - Areia ligeiramente argilosa \\
\hline \multirow[t]{3}{*}{6} & Centro & AII - Areia ligeiramente argilosa & BIV - Areia muito argilosa \\
\hline & Margem Esquerda & AII - Areia ligeiramente argilosa & AII - Areia ligeiramente argilosa \\
\hline & Margem Direita & AII - Areia ligeiramente argilosa & AII - Areia ligeiramente argilosa \\
\hline \multirow[t]{2}{*}{7} & Centro & CIV - Lodo arenoso argiloso & BIV - Areia muito argilosa \\
\hline & Margem Esquerda & BIII - Areia argilosa & AII - Areia ligeiramente argilosa \\
\hline
\end{tabular}




\section{CONCLUSÕES}

Foi possível observar que, diferentemente de outros autores, durante a Estação Chuvosa, quando as temperaturas ficaram em torno de $28,02 \pm 1,69{ }^{\circ} \mathrm{C}$, portanto mais elevadas do que na Estação Seca, $\operatorname{com} 22,46 \pm 1,04{ }^{\circ} \mathrm{C}$, as taxas de oxigênio dissolvido foram também mais elevadas, da ordem de $5,80 \pm 2,52 \mathrm{mg} \mathrm{L}^{-1}$, porém com muito maior variação.

$\mathrm{O} \mathrm{pH}$ do ambiente aquático manteve-se praticamente inalterado, próximo ao neutro, com leve tendência de aumento em direção ao Reservatório.

Foi observado que as taxas de deposição de sólidos suspensos foram 153,72\% maiores durante a Estação Chuvosa, com 29,00 $\pm 20,79 \mathrm{~g} \mathrm{~m}^{-2}$ dia $^{-1}$, sendo que as taxas durante a Estação Seca foram de 11,43 $\pm 11,96 \mathrm{~g} \mathrm{~m}^{-2} \mathrm{dia}^{-1}$, com destaque para as taxas observadas nos Transectos 1 e 2 .

As taxas de deposição nitrogênio total Kjeldahl foram 282,81\%, em média, superiores durante a Estação Seca, cujos valores ficaram em torno de 2,02 $\pm 0,83 \mathrm{~g} \mathrm{~m}^{-2} \mathrm{dia}^{-1}$, quando os valores durante a Estação Chuvosa foram de $0,53 \pm 0,09 \mathrm{~g} \mathrm{~m}^{-2} \mathrm{dia}^{-1}$.

Com 139,67 $\pm 60,76 \mathrm{mg} \mathrm{m}^{-2} \mathrm{dia}^{-1}$ as taxas de deposição de fósforo total foram 34,44\% maiores, em média, durante a Estação Chuvosa do que durante a Estação Seca, cujos valores foram de $103,89 \pm 93,56 \mathrm{mg} \mathrm{m}^{-2} \mathrm{dia}^{-1}$.

As taxas de deposição de silicatos reativos não apresentaram variações significativas entre Estações.

Mesmo com as menores velocidades médias registradas durante a Estação Chuvosa, as taxas de exportação de sólidos suspensos foram $220,74 \%$ maiores do que na Estação Seca, e alcançou valores de $2328,44 \pm 1506,24$ ton dia $^{-1}$. Somente considerando as exportações médias para o Reservatório de Três Irmãos este valor equivale a 1844,83 ton $\mathrm{dia}^{-1}$.

Para o elemento nitrogênio total Kjeldahl as taxas de exportação foram 146,96\% maiores na Estação Chuvosa, com 299,84 \pm 247,91 ton dia ${ }^{-1}$, enquanto que as taxas na Estação Seca foram de 121,41 $\pm 126,95 \mathrm{dia}^{-1}$. A exportação média de nitrogênio total para o Reservatório de Três Irmãos foi de 379,82 ton dia $^{-1}$.

O fósforo total obteve taxa de exportação cerca de 32,26\% maior na Estação Chuvosa, com valores de 14,86 $\pm 10,03$ ton dia $^{-1}$, com exportação média para o Reservatório de Três Irmãos da ordem de 14,95 ton dia $^{-1}$. 


\section{RECOMENDAÇÕES FINAIS}

As taxas de deposição e exportação analisadas neste trabalho podem servir de subsídio para tomadores de decisão quanto à implementação de práticas agrícolas menos agressivas ao meio ambiente, pois $89,70 \%$ da área da bacia analisada estão sendo utilizados para plantio de cana de açúcar $(11,44 \%)$ e para pastagens $(78,26 \%)$.

Naquela região, não há fontes pontuais de sedimentos ou nutrientes provenientes de efluentes industriais ou mesmo domésticos, conforme a própria característica da bacia. Porém, há no mínimo uma fonte significativa de sedimentos na região, que corresponde a uma voçoroca com mais de $3 \mathrm{~km}$ de extensão e trechos com mais de 8 metros de altura, que certamente foi, e ainda é, grande fonte de partículas sólidas para o Ribeirão das Cruzes.

No entanto, como evidenciado ao longo do trabalho, as pastagens estão ocupando áreas de preservação permanente em desacordo com as legislações ambientais vigentes no país. Desta forma estas áreas não estão cumprindo uma de suas principais funções ecológicas que é preservar os recursos hídricos e desta forma não impede que os sedimentos, que naturalmente são carreados pelas águas pluviais, causem o assoreamento do corpo d'água.

Além disso, com as altas taxas de deposição e também de exportação de nutrientes, a sub-bacia está sujeita a processos de eutrofização com consequente perda da qualidade da água para atividades de pesca, recreação e proliferação de plantas aquáticas, como já discutido neste trabalho.

Referente a análise das taxas de deposição propriamente dita, verificou-se que os resultados dependem muito da situação que ocorre durante o período de incubação das câmaras. Por isto é importante ressaltar que durante os experimentos da Estação Chuvosa, houve eventos de chuva, inclusive no momento de incubação de algumas câmaras.

Neste sentido alguns pesquisadores recomendam utilizar períodos de incubação mais longos, porém o risco de perda dos equipamentos é alto, e pode-se com isto perder não somente um período hidrológico completo de dados, mas também o trabalho como um todo. De qualquer forma, a geração de conhecimentos para uma área, geográfica, ainda não muito pesquisada é importante e deve sempre ser priorizada em relação à realização de trabalhos em locais já há muito tempo estudados.

A partir dos dados de deposição, seria possível, ainda, relacionar estas taxas às áreas de seus respectivos compartimentos e obter taxas de deposição por unidade de tempo, e não mais por unidade de área e tempo, como apresentado neste trabalho. 
De posse destes dados e dos dados de exportação, seria possível analisar a eficiência de retenção do Ribeirão das Cruzes, que como explicado e evidenciado ao longo do trabalho, tem comportamento de reservatório, ou seja, de sistema lêntico, e por isto é mais comum que esses sistemas atuem como locais de deposição de sólidos e nutrientes.

Porém, para isto seria preciso relacionar as medidas de profundidade dos transectos com um nível referencial, pois há oscilações do nível da água entre Estações, e ainda calcular a área do espelho d'água daquele exato momento, o que também requer um modelo digital de elevação de toda a bacia do Ribeirão das Cruzes. Tais estudos não foram realizados por não fazerem parte dos objetivos desse trabalho, mas são úteis para ideias de trabalhos futuros a serem realizados.

Também há de considerar a quantidade de novos trabalhos que envolvem softwares para modelagem dos processos de produção de sedimentos segundo as características de uso e ocupação do solo da bacia. Por muitas vezes os modelos matemáticos utilizados requerem dados prévios para calibração, neste sentido, também pensando-se em trabalhos futuros, é possível utilizar os dados gerados neste trabalho para calibrar um modelo e estudar os processos de produção de sedimentos da bacia como um todo. 


\section{REFERÊNCIAS BIBLIOGRÁFICAS}

AGÊNCIA NACIONAL DE ÁGUAS (ANA). Medição de descarga líquida em grandes rios: manual técnico. Brasília: ANA, SGH, 2009. 88 p.

AMERICAN PUBLIC HEALTH ASSOCIATION (APHA). Standard methods for the examination of water and wastewater. $20^{\text {th }}$ ed. Washington, APHA, 1999.

ANDERSEN, J. M. In: ignition method for determination of total phosphorus in lake sediments. Wat. Res., 10, 1976, p.329-331.

ASSOCIAÇÃO BRASILEIRA DE NORMAS TÉCNICAS (ABNT). NBR 7181: Solos - Análise Granulométrica. Rio de Janeiro, 1984.

NBR 6502: Rochas e Solos. Rio de Janeiro, 1995.

BERTOL, I. Perdas de nutrientes por erosão hídrica em diferentes sistemas de manejo de solo sob rotação de culturas. Univ. Des., 2:174-184, 1994.

BERTONI, J. e LOMBARDI NETO, F. Conservação do solo. 4ª Edição. São Paulo: Ícone, 1999. 355p.

BIGARELLA, J. J.; MAZUCHOWSKI, J. Z. Visão integrada da problemática da erosão. In: ABGE/ADEA. Maringá/PR, 1985. 332p.

BLOESCH, J.; STADELMANN, P.; BÜHRER, H. Primary production, minerlization, and sedimentron in the enphotic zone of two Swiss lakes. Limnology and Oceanography, Baltimore, v. 22, n. 5, p. 511-526, 1977.

BRAMORSKI, J. Avaliação da perda de solo e nutrientes nitrogenados por erosão em áreas agrícolas: uma abordagem integrada e experimental dos fatores intervenientes no processo. 2007.197 p. Tese (Doutorado) - Universidade de São Paulo, Escola de Engenharia de São Carlos, São Carlos, 2007.

Avaliação da qualidade de sedimentos dos rios Tietê e Piracicaba no compartimento de entrada do Reservatório de Barra Bonita, SP. 2004. 135 p. Dissertação (Mestrado) - Universidade de São Paulo, Escola de Engenharia de São Carlos, São Carlos, 2004.

BRIGHT, C. Estado do Mundo: a impossível revolução ambiental está acontecendo. Salvador: WWI-UMA Ed., 2003. 226 p. 
BUFON, A. G. M. Variação temporal e espacial da taxa de sedimentação e das características limnológicas na microbacia do córrego da Barrinha, no município de Pirassununga, SP. 2002. 180 f. Dissertação (Mestrado) - Universidade Estadual Paulista, Centro de Estudos Ambientais, Rio Claro, 2002.

CANIL, K.; IWASA, O. Y.; SILVA, W. S.; ALMEIDA, L. E. G. Mapa de feições erosivas lineares do Estado de São Paulo: Uma análise qualitativa e quantitativa. In: $5^{\circ}$ Simpósio nacional de controle de erosão. ABGE/UNES. Bauru/SP, 1995. p. 249-251.

CAMARGO, A. A. B. Avaliação e quantificação da contribuição de uma voçoroca para o assoreamento do Ribeirão das Cruzes, tributário da represa de Três Irmãos, SP. Dissertação (Mestrado) - Universidade de São Paulo, Escola de Engenharia de São Carlos, São Carlos, 2012.

CARMO, C. F. Aporte de nutrientes, nitrogênio e fósforo, e sua relação com os impactos antropogênicos em um lago urbano, São Paulo, SP, Brasil. Dissertação (Mestrado) - Universidade de São Paulo, Escola de Engenharia de São Carlos, São Carlos, 2000.

CARVALHO, N. O. Hidrossedimentologia prática. $2^{\text {a }}$ Edição. Rio de Janeiro: Interciência, 2008.

CARVALHO, N. O; FISIOLA JUNIOR, N. P; SANTOS, P. M. C; LIMA, J. E. F. W. Guia de avaliação de assoreamento de reservatórios. Brasília: ANEEL, 2000a. 140 p.

Guia de práticas sedimentométricas. Brasília: Dupligráfica, 2000b. 154 p.

CASTRO, R. M. C. e MENEZES, N. A. Estudo diagnóstico da diversidade de peixes do Estado de São Paulo. In: Biodiversidade do Estado de São Paulo, Brasil: Síntese do conhecimento ao final do século XX, 6: vertebrados (R.M.C. Castro, ed.). WinnerGraph, São Paulo, 1998, p. 1-13.

CAVENAGHI, A. L.; VELINI, E. D.; NEGRISOLI, E.; CARVALHO, F. T.; GALO, M. L. B. T.; TRINDADE, M. L. B.; CORRÊA, M. R.; SANTOS, S. C. A. Monitoramento de problemas com plantas aquáticas e caracterização da qualidade de água e sedimento na UHE Mogi-Guaçu. Planta daninha [online]. Vol.23, n.2, 2005, p. 225-231.

CEMIG. Manual de hidrometria. Divisão de Hidrologia Belo Horizonte, MG. 1965.

CENTRO TECNOLÓGICO DA FUNDAÇÃO PAULISTA DE TECNOLOGIA E EDUCAÇÃO - CETEC. Situação dos recursos hídricos do Baixo Tietê - UGRHI 19. Relatório Técnico Final. Lins, São Paulo, 2001. 261 p.

Plano de Bacia do Baixo Tietê 2008 - Relatório Final. 282 p.

CERRI, L. E. S.; SILVA, J. A. F.; SANTOS, P. H. P. Erosão do solo: aspectos conceituais. Revista da Universidade de Guarulhos, Geociências,1997. p. 92-98. 
CNRH. Resolução no. 32, de 15 de outubro de 2003. Anexo I. Conselho Nacional de Recursos Hídricos. Brasília, DF: Ministério do Meio Ambiente, 2003.

COOK, H. L. The nature and controlling variables of water erosion process. Soil Sci. Soc. America Proc., v. 1, p. 487-494, 1936.

COSTA, J. B. Avaliação ecotoxicológica da água e sedimento de tributários do reservatório de Barra Bonita (Médio Tietê Superior-SP). 2001. 281 p. Dissertação (Mestrado) - Universidade de São Paulo, Escola de Engenharia de São Carlos, São Carlos, 2001.

DANIEL, T.C.; SHARPLEY, A.N.; EDWARDS, D.R.; WEDEPOHL, R. \& LEMUNYON, J.L. Minimizing surface water eutrophication from agriculture by phosphorus management. J. Soil Water Conserv., 40:30-38, 1994.

DEPARTAMENTO DE ÁGUAS E ENERGIA ELÉTRICA (DAEE). Controle de erosão: bases conceituais e técnicas; diretrizes para o planejamento urbano e regional; orientações para o controle de voçorocas urbanas. São Paulo: DAEE/IPT, 1990. 92 p.

DIN, Z. B. Use of aluminium to normalise heavy metal data from estuarine and coastal sediments of straits of Melaska. Marine Poll. Bull, (24), 10, 1992, p. 484-491.

DORNFELD, C. B; MASSUTTI, M.B; SILVÉRIO, P. F; ALMEIDA, C. A. Caracterização ecotoxicológica do sedimento da Represa do Lobo (Itirapina-Brotas, SP) e seus tributários. In: Recursos hidroenergéticos: usos, impactos e planejamento integrado. v. 1. Editora: Rima, São Carlos, 2002, p. 75-90.

EDMONDSON, W. T. e WINBERG, G. G. A manual of methods for assessment of secondary productivity in fresh waters. Oxford, Blackweel Scientific Publications, 1972.

EDWARDS, T. K. e GLYSSON, G. D. Field Methods for Measurement of Fluvial Sediment. In: Applications of hydraulics. USGS. Techniques of Water Resources Investigations of the United States Geologycal Survey. TWRI 3 - C2. Arlington. VA, 1998, 89p.

EILERS, V. H. Relatório parcial de atividades do projeto vinculado ao programa Prodoc da Capes USP/EESC/PPG-SEA/EMBRAPA, 2003.

ELTZ, F.L.F.; PEIXOTO, R.T.G. e JASTER, F. Efeitos de sistemas de preparos do solo nas propriedades físicas e químicas de um Latossolo Bruno álico. R. Bras. Solo, 13:259-267, 1989.

ESTEVES, F. A. Fundamentos da limnologia. 2ed. Rio de Janeiro: Interciência, 1998. 602 p.

FIGUEIREDO Jr., A. G. e I. BREHME. Amostragem geológica na pesquisa mineral. Revista Brasileira de Geofísica, 2000, p. 269-280. 
FOLK, R. L. The distinction between grain size and mineral composition in sedimentaryrock nomenclature. Journal of Geology, 1954, p. 344-359.

GEOSI - Geo Seabed Instruments AS. Disponível em: < http://www.geosi.no/>. Acesso em: 01 Jun. 2012.

GUY, H. P. Fluvial Sediment Concepts. In: Applications of hydraulics. USGS. Techniques of Water Resources Investigations of the United States Geological Survey. TWRI 3-C1. Arlington. VA, 1970, 55p.

HENRY, R. A exportação de nutrientes e material em suspensão em alguns cursos de água na bacia do Alto Paranapanema (Estado de São Paulo). Acta Limnol. Brasil., 1992. p. 67-79.

Annual changes in sediment entrapment efficiency in lakes lateral to a river (Paranapanema River, São Paulo, Brazil). Acta Limnologica Brasiliensia, vol. 21, no. 1, 2009, p. 25-34.

HENRY, R.; MARICATO, F. E. Sedimentation rates of tripton in Jurumirim Reservoir (São Paulo, Brazil). Limnologica, v. 26, n. 1, 1996, p. 15-25.

IWASA, O. Y. e PRANDINI, F. L. Diagnóstico da origem e evolução das boçorocas: condição fundamental para preservação e correção. In: Simpósio sobre o controle de erosão. ABGE. Curitiba/PR, 1980. p. 05-34.

KC-DENMARK. Disponível em: <http://www.kc-denmark.dk/>. Acesso em: 01 Jun. 2012.

KING, K.W.; RICHARDSON, C.W. \& WILLIAMS, J.R. Simulation of sediment and nitrate loss on a Vertissol with conservation practices. Trans. Am. Soc. Agric. Eng., v. 6, 1996, p. 2139- 2145.

LAL, R. Soil degradation by erosion. Land degradation \& development. $\mathrm{N}^{\mathrm{o}} 12$, 2001. p. 519-539.

LEITE, M. A. Variação espacial e temporal da taxa de sedimentação no reservatório de Salto Grande (Americana, SP) e sua influência nas características limnológicas do sistema. 1998. 170 f. Dissertação (Mestrado) - Universidade de São Paulo, Escola de Engenharia de São Carlos, São Carlos, 1998.

Análise do aporte, taxa de sedimentação e da concentração de metais na água, plâncton e sedimento do Reservatório de Salto Grande, Americana-SP. 2002. 196 f. Tese (Doutorado) - Universidade de São Paulo, Escola de Engenharia de São Carlos, São Carlos, 2002.

LINDSLEY, B. A. e MARDER, A. R. The effect of velocity on the solid particle erosion rates of alloys. Elsevier, 1999. p. 510-516. 
LOUREIRO, D. D. T. Métodos atuais e novas tecnologias para o monitoramento do transporte de sedimentos em rios: necessidade de dados e incertezas envolvidas. 2008. 91 p. Dissertação (Mestrado) - Universidade de São Paulo, Escola de Engenharia de São Carlos, São Carlos, 2008.

MACIEL FILHO, C. L. Introdução a geologia de engenharia. Santa Maria: Editora da UFSM, 1994. 284p.

MARICATO, F. E. Caracterização físico-química e sedimentação nas regiões de desembocadura dos rios Paranapanema e Taquari, e no reservatório de Jurumirim (Alto Paranapanema-SP). 1994. 205f. Dissertação (Mestrado) - Universidade de São Paulo, Escola de Engenharia de São Carlos, São Carlos, 1994.

MARQUISÁ, G. C. Sedimentação e fluxo vertical de nutrientes em dois reservatórios de distintos estados tróficos (reservatório do Broa e Barra Bonita-SP). 1998. 151 p. Tese (Doutorado) - Universidade de São Paulo Escola de Engenharia de São Carlos, São Carlos, 1998.

MASSUTTI, M. B. O manguezal do Itacorubi como barreira biogeoquímica: estudo de caso. 1999. 196 p. Dissertação (Mestrado) - Universidade Federal de Santa Catarina, Florianópolis, 1999.

McISAAC, G.F.; MITCHELL, J.K. \& HIRSCHI, M.C. Dissolved phosphorus concentrations in runoff from simulated rainfall on corn and soybean tillage systems. $\mathrm{J}$. Soil Water Conserv., 4:383-387, 1995.

MOCCELLIN, J. A Microbacia do rio Jacupiranguinha como unidade de estudo para a sustentabilidade dos recursos hídricos no Baixo Ribeira de Iguape - SP. 2006. Dissertação (Mestrado) - Universidade de São Paulo, Escola de Engenharia de São Carlos, São Carlos, 2006.

Estudo da dinâmica fluvial em duas sub-bacias e proposição de cenários para a sustentabilidade dos recursos hídricos no Baixo Ribeira de Iguape - SP. 2010. Tese (Doutorado) - Universidade de São Paulo, Escola de Engenharia de São Carlos, São Carlos, 2010.

MOZETO, A. A. Workshop de avaliação do projeto qualised: bases técnico-científicas para o desenvolvimento de critérios de qualidade de sedimentos-experimentos de campo e laboratório. São Carlos: UFSCAR, 2001. 69 p.

PICHLER, E. Boçorocas. Boletim da Sociedade Brasileira de Geologia - SBG, 1953. p. 3-16.

PIÃO, A. C. S. Transporte de nitrogênio, fósforo e sedimentos pelo ribeirão dos carrapatos (Município de Itaí, SP), sua relação com usos do solo e outros impactos antropogênicos e a sua deposição no braço do Taquari Represa de Jurumirim. 1995. 192f. Tese (Doutorado) - Universidade de São Paulo, Escola de Engenharia de São Carlos, São Carlos, 1995. 
PONÇANO, W. L. e PRANDINI, F. L. Boçorocas no Estado de São Paulo: uma revisão. In: Anais do $4^{\mathbf{0}}$ Simpósio nacional de controle de erosão. Marília/SP, 1987. p. 149-175.

POTE, D.H.; DANIEL, T.C. \& SHARPLEY, A.M. Relating extractable soil phosphorus to phosphorus losses in runoff. Soil Sci. Soc. Am. J., 60:855-859, 1996.

PROIN/CAPES e UNESP/IGCE. Material Didático: arquivos de transparências (CD). Rio Claro: Departamento de Geologia Aplicada, 1999.

RODGHER, S.; ESPÍNDOLA, E. L. G.; ROCHA, O.; FRACÁCIO, R.; PEREIRA, R. H. G.; RODRIGUES, M. H. S. Limnological and ecotoxicological studies in the cascade of reservoirs in the Tietê river (São Paulo, Brazil). Braz. J. Biol. [online]. Vol. 65, n.4, 2005, p. $697-710$.

RODRIGUES, J. E. e VILAR, O. M. Estudos da erosão interna em boçorocas através da teoria do carreamento. In: $\mathbf{4}^{\mathbf{0}}$ Congresso brasileiro de geologia de engenharia. Belo Horizonte. Anais, v2. ABGE, 1984. p. 163-169.

RODRIGUES, J. E. Estudos de fenômenos erosivos acelerados - boçoroca. 1982. Tese (Doutorado) - Universidade de São Paulo, Escola de Engenharia de São Carlos, São Carlos, 1982.

SALOMÃO, F. X. T. Solos do arenito Bauru. In: PEREIRA, V. P.; FERREIRA, M. E; CRUZ, M. C. P. (Eds). Solos altamente suscetíveis à erosão. FCAV - UNESP/SBCS. Jaboticabal, 1992. p. 50-68.

SÃO PAULO. Lei n. ${ }^{\circ}$ 7663, de 30 de dezembro de 1991. Estabelece normas de orientação à Política Estadual de Recursos Hídricos bem como ao Sistema Integrado de Gerenciamento de Recursos Hídricos. Diário Oficial do Estado, São Paulo, SP, 31 de dezembro de 1991, p. 2/5.

Lei n. ${ }^{\circ}$ 9034, de 27 de dezembro de 1994. Dispõe sobre o Plano Estadual de Recursos Hídricos - PERH, a ser implantado no período 1994 e 1995, em conformidade com a Lei $n^{\circ}$ 7.663, de 30 de dezembro de 1991, que instituiu normas de orientação à Política Estadual de Recursos Hídricos. Diário Oficial do Estado, São Paulo, SP, 27 de dezembro de 1994.

SCHICK, J.; BERTOL, I.; BALBINOT Jr., A.A. \& BATISTELA, O. Erosão hídrica em Cambissolo Húmico alumínico submetido a diferentes sistemas de preparo e cultivo do solo: II. Perdas de nutrientes e carbono orgânico. R. Bras. Ci. Solo, 24:437-447, 2000.

SEGANFREDO, M.L.; ELTZ, F.L.F. \& BRUM, A.C.R. Perdas de solo, água e nutrientes por erosão em sistemas de culturas em plantio direto. R. Bras. Ci. Solo, 21:287-291, 1997.

SHEPARD, F. P. Nomenclature based on sand-silt-clay ratios. Journal Sedimentary Petrology, v. 24, 1954, p. 151-158. 
SILVA, F. G. B e CRESTANA, S. Modelos e formulações pra análise de erosão de solos em bacias hidrográficas voltados ao planejamento ambiental. In: Ciências Ambientais: diversas abordagens para a bacia hidrográfica. São Carlos: Rima Ed. 2004.

SIMÕES, L. B. Integração entre um modelo de simulação hidrológica e sistema de informação geográfica na delimitação de zonas tampão ripárias. Botucatu. Tese (Doutorado) - Faculdades de Ciências Agronômicas da Universidade Estadual Paulista. 2001. $271 \mathrm{p}$.

SOARES, A. e MOZETO, A. A. Water Quality in the Tietê River Reservoirs (Billings, Barra Bonita, Bariri and Promissão, SP-Brazil) and Nutrient Fluxes across the Sediment-Water Interface (Barra Bonita). Acta Limnologica Brasiliensia, 2006, vol. 18, p. 247-266.

TANAKA, R. H.; CARDOSO, L. R.; MARTINS, D.; MARCONDES, D. A. S.; MUSTAFÁ, A. L. Ocorrência de plantas aquáticas nos reservatórios da Companhia Energética de São Paulo. Planta daninha [online]. vol. 20, 2002, p. 101-111.

TEIXEIRA, W.; TOLEDO, M. C. M.; FAIRCHILD, T. R.; TAIOLI, F. (org.). Decifrando a Terra. . $2^{\mathrm{a}}$ ed. São Paulo: Oficina de Textos. 2008. 624 p.

TRINDADE, M. Nutrientes em sedimentos da Represa do Lobo (Brotas-Itirapina, SP). 1980. 291 p. Dissertação (Mestrado) - Universidade Federal de São Carlos, São Carlos, 1980.

VANZELA, L. S.; HERNANDEZ, F. B. T. e FRANCO, R. A. M. A influência do uso e ocupação do solo nos recursos hídricos do Córrego Três Barras, Marinópolis. Revist. Bras. Eng. Agric. Amb, v. 14, n.1, 2010, p. 55-64.

VARGAS, M. Introdução à Mecânica dos Solos. $1^{\text {a }}$ ed. São Paulo: McGraw Hill do Brasil, 1974.

VILAR, O. M. Formulação de um modelo matemático para erosão dos solos pela chuva. 1987. Tese (Doutorado). Escola de Engenharia de São Carlos, Universidade de São Paulo, São Carlos, 1987.

YSI. Yellow Springs Instrument. Disponível em: < http://www.ysi.com>. Acesso em: 01 Jun. 2012.

WEEGEL, J. R. e RUSTOM, R. Soil erosion by rainfall and runoff state of the art. Geotextiles and Geomembranes. V11, 1992. p. 551-572. 